\author{
UNIVERSIDADE DE SÃO PAULO \\ ESCOLA DE ENGENHARIA DE SÃO CARLOS \\ DEPARTAMENTO DE GEOTECNIA
}

CLÁUDIA MARISSE DOS SANTOS ROTTA

ESTUDO DA RECUPERAÇÃO DE ÁREAS DEGRADADAS POR PROCESSOS EROSIVOS: PROCEDIMENTOS E EFICIÊNCIA DOS MÉTODOS.

São Carlos, SP 



\author{
UNIVERSIDADE DE SÃO PAULO \\ ESCOLA DE ENGENHARIA DE SÃO CARLOS \\ DEPARTAMENTO DE GEOTECNIA
}

\title{
ESTUDO DA RECUPERAÇÃO DE ÁREAS DEGRADADAS POR PROCESSOS EROSIVOS: PROCEDIMENTOS E EFICIÊNCIA DOS MÉTODOS.
}

CLÁUDIA MARISSE DOS SANTOS ROTTA

\begin{abstract}
Dissertação apresentada à Escola de Engenharia de São Carlos da Universidade de São Paulo, como parte dos requisitos para a obtenção do título Mestre em Ciências, Programa de Pós Graduação em Geotecnia.
\end{abstract}

ORIENTADOR: Prof. Tit. Lázaro Valentin Zuquette

VERSÃO CORRIGIDA

São Carlos, SP 
AUTORIZO A REPRODUÇÃO E DIVULGAÇÃO TOTAL OU PARCIAL DESTE TRABALHO, POR QUALQUER MEIO CONVENCIONAL OU ELETRÔNICO, PARA FINS DE ESTUDO E PESQUISA, DESDE QUE CITADA A FONTE.

Ficha catalográfica preparada pela Seção de Tratamento da Informação do Serviço de Biblioteca - EESC/USP

R842

Rotta, Cláudia Marisse dos Santos

Estudo da recuperação de áreas degradadas por processos erosivos : procedimentos e eficiência dos métodos / Cláudia Marisse dos Santos Rotta ; orientador Lázaro Valentin Zuquette. -- São Carlos, 2012.

Dissertação (Mestrado - Programa de Pós-Graduação em Geotecnia) - - Escola de Engenharia de São Carlos da Universidade de São Paulo, 2012.

1. Área degradada. 2. Processos erosivos. 3. Técnicas de recuperação de erosão. 4. São Pedro-SP. I. Título. 
FOLHA DE JULGAMENTO

Candidata: Engenheira CLAUDIA MARISSE DOS SANTOS ROTTA.

Título da dissertação: "Estudo da recuperação de áreas degradadas por processos erosivos: procedimentos e eficiência dos métodos".

Data da defesa: 11/06/2012

\section{Comissão Julgadora:}

Prof. Titular Lázaro Valentin Zuquette (Orientador)

(Escola de Engenharia de São Carlos/EESC)

Prof $^{\mathrm{a}}$. Dr ${ }^{\mathrm{a}}$. Marcilene Dantas Ferreira

(Universidade Federal de São Carlos/UFSCar)

$\mathrm{Dr}^{\mathrm{a}}$. Denise Balestrero Menezes

(Pesquisadora - Autônoma)
Resultado:

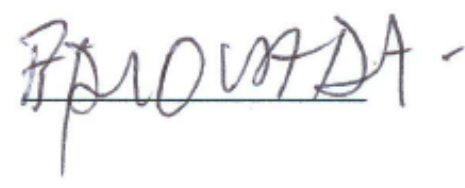

APROVADA

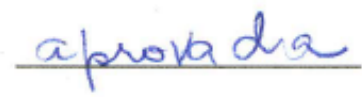

Coordenador do Programa de Pós-Graduação em Geotecnia:

Prof. Titular Osni José Pejon

Suplente do Presidente da Comissão de Pós-Graduação em Exercício:

Prof. Titular Denis Vinicius Coury 

Decido esse trabalho à minha Vó Maria † 



\section{AGRADECIMENTOS}

Agradeço em primeiro lugar a Deus, que traça os meus caminhos e caminha sempre ao meu lado.

Agradeço a toda minha família, em especial aos meus Pais (Cláudio e Mariza) e à minha Tia Regina, por todo o apoio, não só durante o mestrado, mas durante toda a minha vida São Carlense.

Agradeço ao Professor Lázaro, pela orientação, amizade e paciência ao longo dos últimos 5 anos.

Agradeço a todos do Mapeamento com quem convivi desde o início da primeira Iniciação Científica (2007), e que muito contribuíram para o meu desenvolvimento profissional e pessoal. Agradeço a todas essas pessoas também pelos momentos de descontração e pelas amizades que ficaram.

Agradeço também a todos os professores do departamento que direta ou indiretamente contribuíram para o meu aprendizado durante o curso do mestrado. E ainda aos demais funcionários do departamento de Geotecnia, sempre dispostos a ajudar.

Agradeço a todos os alunos do departamento, sobretudo à minha turma, pela convivência prazerosa. Em especial ao meu grupo do (fatídico) laboratório de solos!

Agradeço à CAPES - Coordenação de aperfeiçoamento de pessoal de nível superior pela bolsa concedida para o desenvolvimento desse trabalho.

Agradeço às Professoras Marcilene e a Valéria por terem me dado a oportunidade de atuar em monitorias tão distintas, mas igualmente enriquecedoras.

Agradeço muito a todos aqueles que entraram em uma "cilada" e fizeram campo comigo, prometendo a estes que todas as fotografias serão utilizadas para fins científicos!

Agradeço ainda aos meus Pais, à Mari(scleusa), à Paola e ao Rodrigo por terem pacientemente me ouvido reclamar (e reclamar, e reclamar) nos momentos de dificuldade.

E por fim, aos inventores do chocolate e da coca-cola, que desenvolveram essas pequenas maravilhas que eu, carinhosamente, chamo de "incentivos gastronômicos". 

"...A gente quer ter voz ativa No nosso destino mandar Mas eis que chega a roda viva E carrega o destino prá lá ..." Chico Buarque 



\section{RESUMO}

ROTTA, C. M. S. Estudo da recuperação de áreas degradadas por processos erosivos: procedimentos e eficiência dos métodos, 2012. 166p. Dissertação (Mestrado em Geotecnia), Escola de Engenharia de São Carlos, Universidade de São Paulo, 2012.

Esse trabalho apresenta os resultados de um estudo realizado em quatro áreas degradadas por processos erosivos, em que foram adotadas diferentes medidas de recuperação das feições lineares, no Município de São Pedro, Estado de São Paulo, Brasil. Para sua realização, em uma primeira etapa, foram identificadas as áreas degradadas, seguido de uma avaliação temporal e espacial dos processos erosivos, e a caracterização geológico-geotécnica de cada área. Além disso, foram realizados trabalhos de campo, com o objetivo principal de identificar as medidas de controle ou recuperação de erosão, e de avaliar o seu desempenho. A partir de todas as informações obtidas foram feitas análises quanto à eficiência das medidas de recuperação adotadas em cada área; identificando-se seus sucessos e fracassos, discutindo sua adequação e indicando soluções para os principais problemas. De modo geral, o estudo permitiu observar que a maioria das medidas adotadas teve a eficiência comprometida, em função da não consideração de informações geológicas, geotécnicas e ambientais, e da adoção de medidas inadequadas.

Palavras-chave: Área degradada, Processos erosivos, Técnicas de recuperação de erosão, São Pedro (SP), Brasil. 



\begin{abstract}
ROTTA, C. M. S. Reclamation study of degraded lands by erosion process: efficiency of the procedures and methods, 2012. 166p. Master Dissertation, Escola de Engenharia de São Carlos, Universidade de São Paulo, 2012.

The goal of this work is to present the results obtained from study developed in four degraded areas due to erosive processes, where some reclamation and/or control measures were applied, in the municipality of São Pedro, São Paulo state, Brazil. The study was carried out according some steps, such as: identification of the degraded land, collection of previous data about geological and geotechnical works, analysis of aerial photographs and satellite images for evaluating the temporal and spatial distribution of the erosive processes and, finally, field works to obtain data about the adopted measures. After, the measures adopted in each area were analyzed in terms of adequacy of the reclamation measures. The successes and failures were identified allowing the discussion about its suitability and to propose suggestion to the major problems. The geological, geotechnical and environmental characteristics of the degraded areas and improper actions were responsible for problems of the adopted measures.
\end{abstract}

Keywords: Degraded area, erosion processes, erosion reclamation measures, São Pedro (SP), Brasil. 



\section{LISTA DE FIGURAS}

Figura 1: Formas de encostas (TROEH, 1965 apud RODRIGUES, 1982) ..................................... 32

Figura 2: Formas geométricas das encostas. (RUHE, 1975, apud XUJIONGXIN, 1996)................ 33

Figura 3: Erosão por sulcos em área de pastagem em Corumbataí, São Paulo, Brasil.................. 37

Figura 4: Erosão por ravina em área de pastagem no Município de Corumbataí, São Paulo, Brasil.

Figura 5: Erosão por voçoroca em área de pastagem no Município de Corumbataí, São Paulo,

Brasil.

Figura 6: Erosão em piping no Município de Casa Branca, São Paulo, Brasil

Figura 7: Pastagens com e sem práticas de manejo, com diferentes condições de conservação em Santa Rita do Araguaia, GO.

Figura 8: Seção transversal da Barreira de Galhos (Brush Barrier) (modificado de KELLER e SHERAR, 2003)

Figura 9: Visão esquemática do terraceamento indicando o seccionamento da rampa com a construção de terraços (BERTOLINI, D. et. al., 1989 apud EMBRAPA, 2004)

Figura 10: Terraço tipo Mangum, de base média, construído com terraceador, Acrelância - Acre (EMBRAPA, 2004).

Figura 11: Terraço tipo Nichols, de base estreita, construído com arado reversível, em Bujari Acre (EMBRAPA, 2004).

Figura 12: Medidas relacionadas ao espaçamento entre terraços (modificado de BEASLEY, 1972).

Figura 13: Caixas de Infiltração ou Retenção dispostas ao longo de uma estrada de terra no município de Brotas - SP.

Figura 14: Feição erosiva que havia sido aterrada e foi reativada no município de São Pedro - SP (FERREIRA, 2004).

Figura 15: Voçoroca originada pelo rompimento de obras de drenagem pluvial associadas ao aterramento no município de São Pedro - SP (FERREIRA, 2004). 69

Figura 16: Esquema da estrutura dos muros de flexão e com contraforte (modificado de GRAY e LEISER, 1982)

Figura 17: Esquema da estrutura do muro em caixa (crib wall) (modificado de GRAY e LEISER, 1982) 
Figura 18: Aplicação do muro em fogueira (crib wall) no Mile End Park, Londres, com a aplicação de estacas de madeira e altura de 7,8 metros (http://www.phigroup.co.uk/tags/retainingwalls/mile-end-park-stepney-london)

Figura 19: Exemplo de aplicação de um muro de gabião

(http://www.projectista.pt/produto/muros-de-gabioes-santos-mouta-2/) 71

Figura 20: Rio Cuarto - Argentina. 71

Figura 21: Esquema da estrutura do muro de terra armada (modificado de GRAY e LEISER, 1982).

Figura 22: Aplicação de um muro de terra armada, enfatizando os elementos de cobertura (http://www.terraarmada.com.br/projetos.php?ord=alfa\&propg=8\&x=753125\&anc=1). 72

Figura 23: Muro de blocos de rocha em Ouro Pedro- MG. 74

Figura 24: Esquema da estrutura de muros de estacas e do muro atirantado (modificado de GRAY e LEISER, 1982). 75

Figura 25: Cordões de pedras em área agrícola da Etiópia (NYSSEN et al, 2007). 77

Figura 26: Cordão de pedras preenchido com solo rico em fragmentos de rocha (NYSSEN et al, 2007)

Figura 27: Voçoroca do Jardim Botânico de Goiânia - GO, com interceptação do nível freático (SPONGA e COELHO, 2001).

Figura 28: Construção do canal principal e da canaleta, integrantes do sistema de drenagem da recuperação da voçoroca do Jardim Botânico de Goiânia - GO (SPONGA e COELHO, 2001)....... 80 Figura 29: Retaludamento das paredes da voçoroca no entorno do canal principal da feição do Jardim Botânico de Goiânia - GO (SPONGA e COELHO, 2001).

Figura 30: Voçoroca do Jardim Botânico de Goiânia - GO totalmente recuperada (SPONGA e COELHO, 2001). 80

Figura 31: Exemplo de galeria em construção em São Pedro - SP (FERREIRA, 2004). 81

Figura 32: Esquema de um poço de visita (FERNANDES, 2002). 82

Figura 33: Exemplo de uma caixa de ligação (http://www.jtbterraplenagem.com.br/obras.html).

Figura 34: Exemplo de boca-de-lobo gradeada

(http://pt.wikipedia.org/wiki/Ficheiro:Boca_de_lobo.JPG). 84

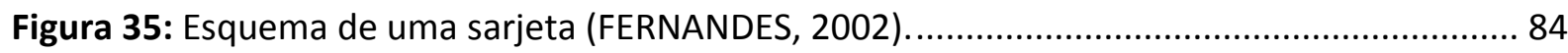

Figura 36: Dreno de fundo, ou enterrado, do tipo cedo (DAEE, 1990)..................................... 87

Figura 37: Dreno de fundo, ou enterrado, de geotextil (DAEE, 1990) .......................................... 88 
Figura 38: Dreno de fundo, ou enterrado de bambu (DAEE, 1990)......

Figura 39: Fluxograma indicando as principais etapas do trabalho

Figura 40: Localização das áreas de estudo pertencentes ao município de São Pedro - SP.

Figura 41: Secção dos materiais geológicos (SE - NW) e das zonas geomorfológicas das Áreas

$1,2,3$ e 4 96

Figura 42: Materiais Geológicos presentes na Área 1.

Figura 43: Superfície 3D representativa da Área 1, com localização das principais feições erosivas.

Figura 44: Voçoroca F3, bastante ativa, localizada na margem direita do córrego 103

Figura 45: Feição F5, bastante ativa, localizada na margem direita do córrego. 103

Figura 46: Feição F11, de menor porte, localizada na margem esquerda. 104

Figura 47: Voçoroca F14, com processo erosivo ativo, que se localizada na margem esquerda, próxima à nascente.

Figura 48: Trecho de uma das ruas do loteamento da Área 1 degradada por sulcos ravinas..... 105

Figura 49: Trecho de uma encosta da Área 1 com a presença de sulcos. 105

Figura 50: Cobertura do solo com pastagens na Área 1. 106

Figura 51: Esquema de um cordão de nível presente nas encostas da Área 1. 106

Figura 52: Dique ou barreira de proteção associado à rua principal com o objetivo de diminuir o escoamento superficial que alcança as grandes feições da região. 107

Figura 53: Caixa de Passagem próxima a uma das ruas para redirecionamento da água de escoamento superficial.

Figura 54: Blocos de rocha dispostos na frente de uma saída de tubulação para contenção da velocidade do escoamento.

Figura 55: Muro de contenção posicionado na frente de uma saída de tubulação para contenção da velocidade do escoamento.

Figura 56: Cordão de nível construído na frente de uma saída de tubulação para evitar que o escoamento superficial acelere a erosão no local.

Figura 57: Delimitação dos conjuntos das principais feições de grande porte existentes na Área 2, para o ano de 1972

Figura 58: Delimitação das áreas que apresentam diferentes medidas de recuperação da erosão, para o ano de 2006

Figura 59: Superfície 3D representativa da Área 2, com localização das principais feições erosivas 
Figura 60: Cabeceira da Feição F2 pertencente à Área 2.

Figura 61: Feição F2, com destaque para a presença de água no interior.

Figura 62: Feição F12 reativada em lotes não ocupados do bairro Jardim Botânico (Área 2) .... 121

Figura 63: Feição F15, próxima a F2, que surgiu após a ocupação urbana da Área 2. 121

Figura 64: Detalhe para o processo de piping e a presença de água no interior da feição F15.. 122

Figura 65: Representação do tipo de uso e de medidas de controle da erosão das áreas R4 e R5.

Figura 66: Área próxima à R8 com plantação de mudas, indicando uma iniciativa de revegetação de uma área não ocupada, próxima à drenagem principal. 124

Figura 67: Plantação de pinus em associação com cordões de nível no entorno da feição F2, com o objetivo de controle do processo erosivo. 125

Figura 68: Barragem de sedimento no interior da feição F2 125

Figura 69: Lixo depositado por moradores no interior da feição F2. 126

Figura 70: Entulho depositado por moradores no entorno da feição F2. 126

Figura 71: Via sem estruturas coletoras da água pluvial, com inclinação que favorece a concentração do escoamento, que é interceptado por uma canaleta que direciona o fluxo para uma área desocupada, próxima ao canal de drenagem.

Figura 72: Principal feição erosiva da Área 3 e sua evolução ao longo do tempo. 130

Figura 73: Superfície 3D representativa da Área 3, com localização das principais feições erosivas.

Figura 74: Feição F6, bastante ativa, e com ramificações.

Figura 75: Feição F3, com potencial para evolução.

Figura 76: Feição F4, pouco evoluída, mas com potencial para aceleração dos processos erosivos nos períodos chuvosos. 134

Figura 77: Barreira de proteção na forma de elevações de solo, dispostas ao redor da área, onde estão localizadas as feições erosivas da Área 3. 135

Figura 78: Delimitação das principais feições erosivas da Área 4, com detalhe para o ocupação da área por pastagens. 138

Figura 79: Delimitação das principais feições erosivas da Área 4, com detalhe para o ocupação da párea por plantação de eucalipto. 138

Figura 80: Superfície 3D representativa de uma das bacias hidrográficas que compreendem a Área 4, com localização das principais feições erosivas. 140 
Figura 81: Superfície 3D representativa de uma das bacias hidrográficas que compreendem a Área 4, com localização das principais feições erosivas

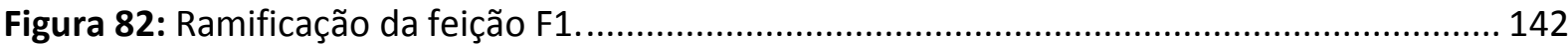

Figura 83: Ramificação da F1 com presença de água no interior. .............................................. 142

Figura 84: Feição F2, com a presença de vegetação no interior................................................ 142

Figura 85: Ramificação da feição F3, com a presença de seixos............................................... 143

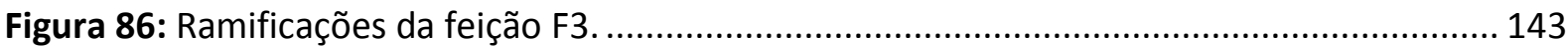

Figura 87: Resíduos de galho e cascas de madeira dispostos entre as fileiras de eucalipto....... 144

Figura 88: Galhos e folhagem secos dispostos entre as fileiras de eucalipto............................ 145

Figura 89: Depressões no solo, na lateral da feição F2, para interceptação e diminuiç̧ão do escoamento superficial, por meio do aumento da infiltração. 



\section{LISTA DE TABELAS}

Tabela 1: Classificação, quanto ao tipo, das principais medidas de prevenção, controle, mitigação e recuperação de erosão.

Tabela 2: Valores de espaçamento entre terraços obtidos a partir de experiências locais nos Estados Unidos (AYRES, 1936) 61

Tabela 3: Características básicas das formações geológicas da região. 95

Tabela 4: Caracterização química e física dos materiais inconsolidados retrabalhados arenosiltosos (FERNANDES, 2003). 98

Tabela 5: Erodibilidade dos materiais inconsolidados retrabalhados areno-siltosos, obtidos pelos métodos de PEJON (1992), e de NOGAMI e VILLIBOR (1979) (FERNANDES, 2003). 99

Tabela 6: Caracterização das principais feições erosivas da Área 1. 102

Tabela 7: Caracterização química e física dos materiais inconsolidados residuais da Formação Pirambóia. (FERNANDES, 2003).

Tabela 8: Caracterização química e física dos materiais inconsolidados residuais da Formação Pirambóia. (YAMANOUTH, 2003).

Tabela 9: Erodibilidade dos materiais inconsolidados residuais da Formação Pirambóia, obtidos pelos métodos de PEJON (1992), e de NOGAMI e VILLIBOR (1979) (YAMANOUTH, 2003).

Tabela 10: Caracterização química e física dos materiais inconsolidados Retrabalhados Arenosos de topo (FERNANDES, 2003).

Tabela 11: Caracterização química e física dos materiais inconsolidados Retrabalhados Arenosos de Topo (YAMANOUTH, 2003).

Tabela 12: Erodibilidade dos materiais inconsolidados Retrabalhados Arenosos de Topo, obtidos pelos métodos de PEJON (1992), e de NOGAMI e VILLIBOR (1979) (YAMANOUTH, 2003)......... 116

Tabela 13: Caracterização das principais feições erosivas da Área 2. 118

Tabela 14: Caracterização das principais feições erosivas da Área 3.

Tabela 15: Caracterização química e física dos materiais inconsolidados Retrabalhados Arenosiltosos (FERNANDES, 2003).

Tabela 16: Erodibilidade dos materiais inconsolidados Retrabalhados Areno-siltosos, obtidos pelos métodos de PEJON (1992), e de NOGAMI e VILLIBOR (1979) (FERNANDES, 2003). 137

Tabela 17: Caracterização das principais feições erosivas encontradas na Área 4. 139

Tabela 18: Síntese da análise da eficiência das técnicas avaliadas nesse trabalho. 150 



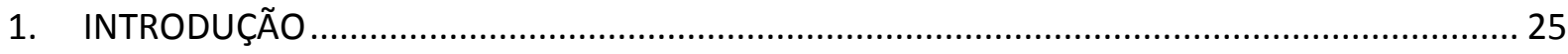

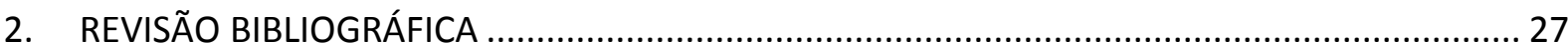

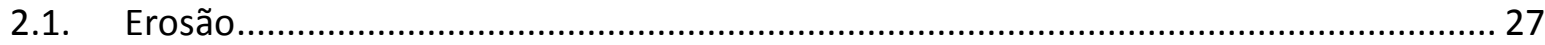

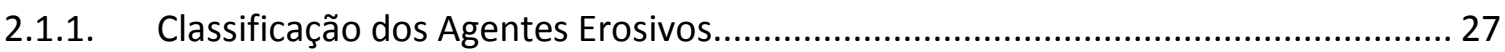

2.2. Fatores Condicionantes da Erosão Hídrica ................................................................ 28

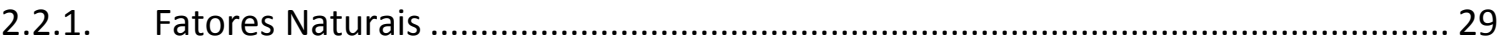

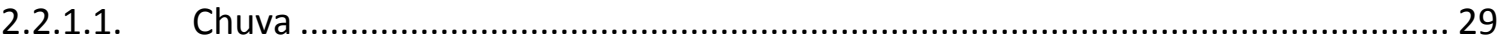

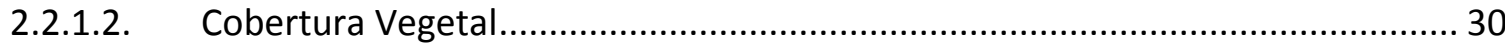

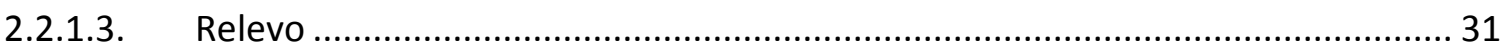

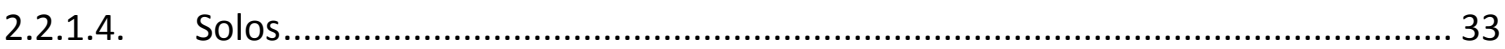

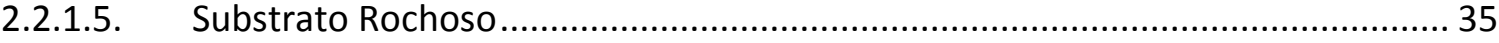

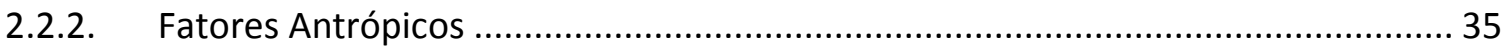

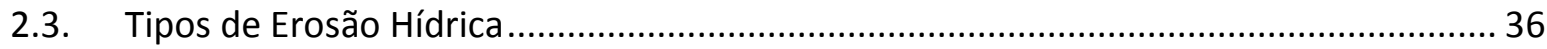

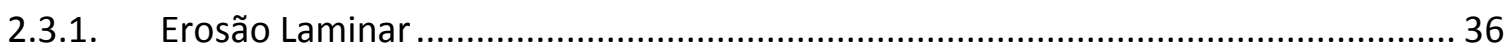

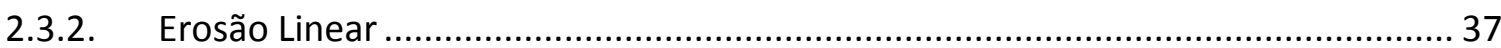

2.4. Aspectos relacionados à degradação e recuperação...................................................... 40

2.5. Medidas de Controle de Erosão Pluvial ...................................................................... 42

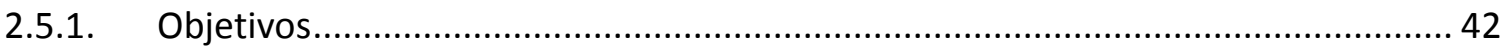

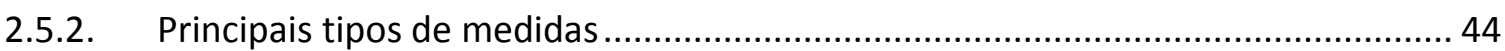

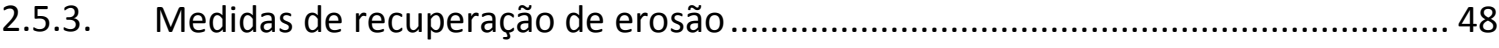

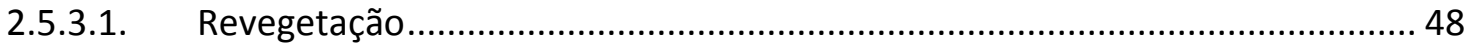

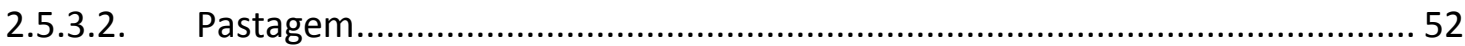

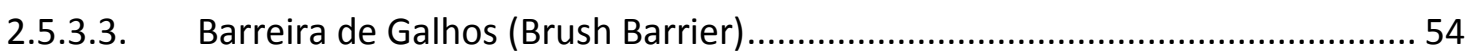

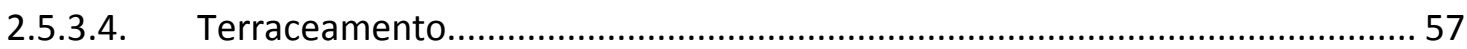

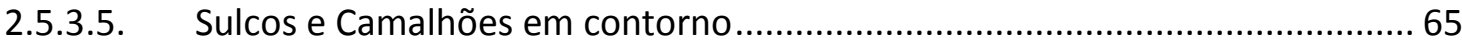

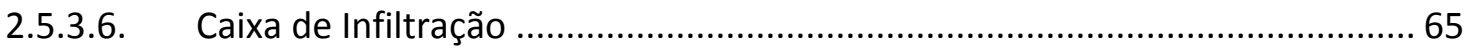

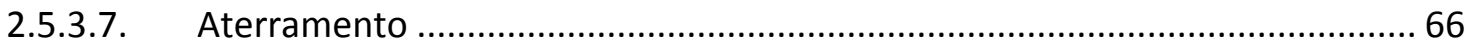

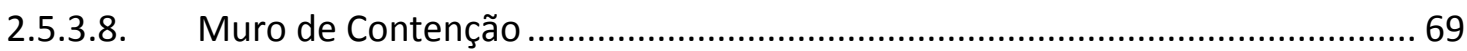

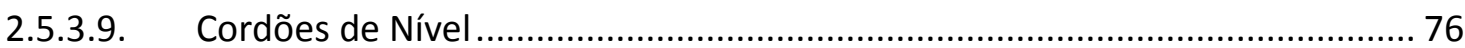

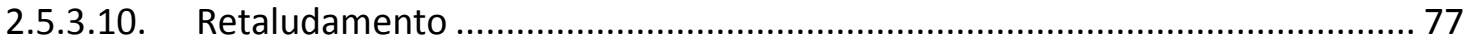




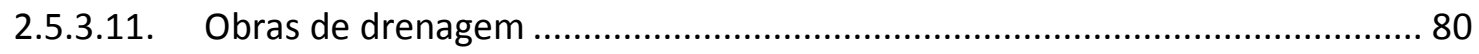

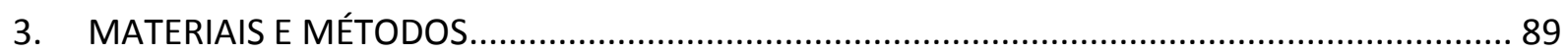

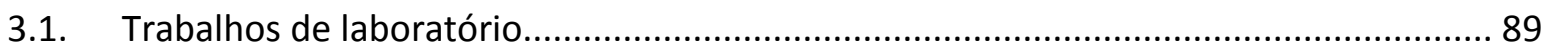

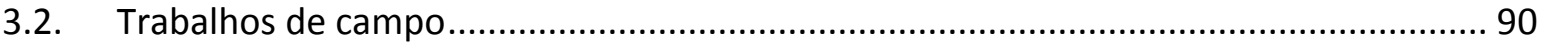

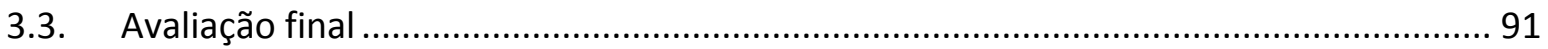

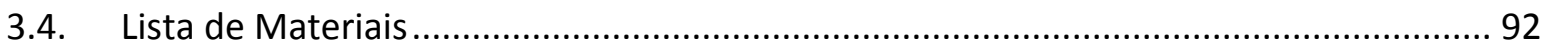

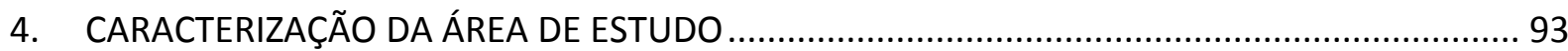

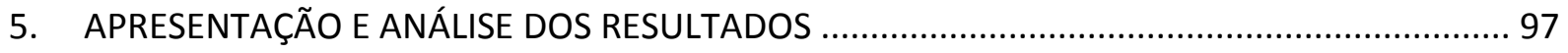

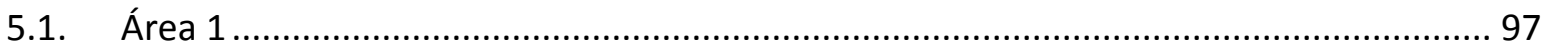

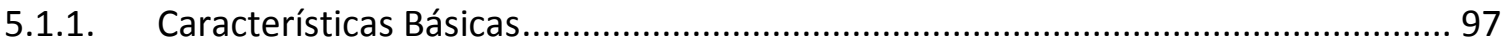

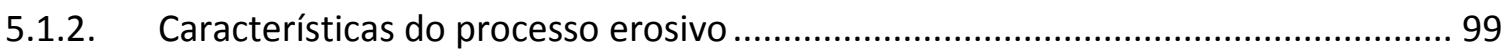

5.1.3. Descrição das medidas de recuperação................................................................. 105

5.1.4. Análise da eficiência das medidas de recuperação de erosão ................................. 110

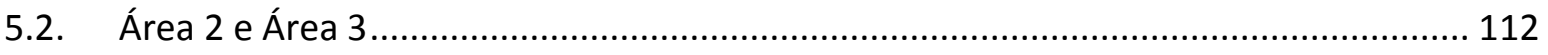

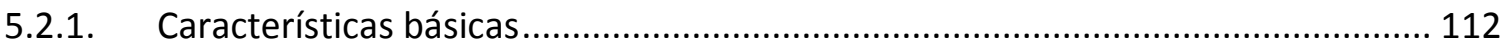

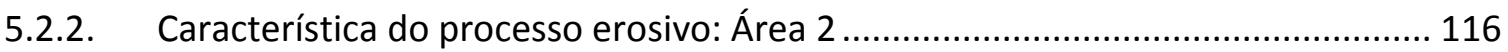

5.2.3. Descrição das medidas de recuperação: Área 2 .................................................. 122

5.2.4. Análise da eficiência das medidas de recuperação de erosão: Área 2 .................. 127

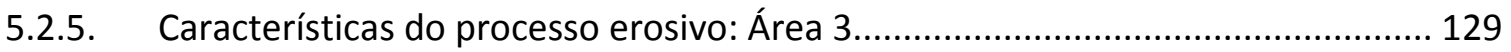

5.2.6. Descrição das medidas de recuperação: Área 3 …............................................. 134

5.2.7. Análise da eficiência das medidas de recuperação de erosão: Área 3 .................. 135

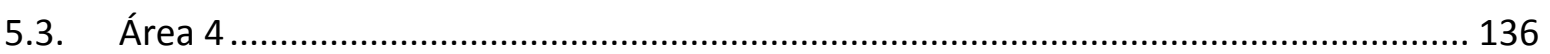

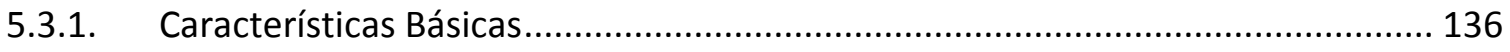

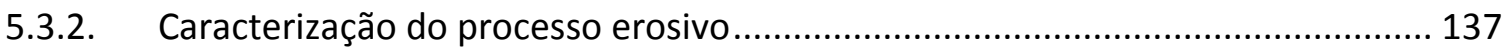

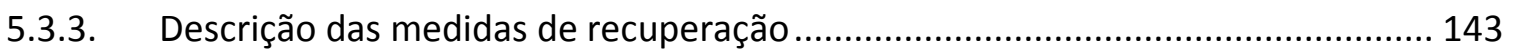

5.3.4. Análise da eficiência das medidas de recuperação de erosão ................................ 146

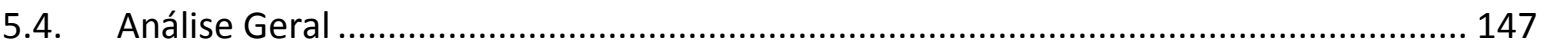

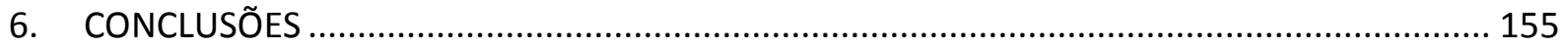

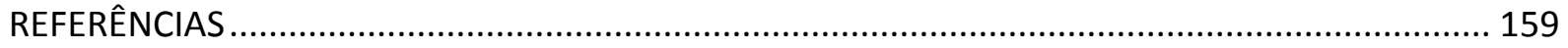

ANEXO 1 


\section{INTRODUÇÃO}

Atualmente cerca de 70\% das áreas continentais sofreram modificações (degradação) em suas condições naturais devido à ação do Homem, tanto na forma de exploração de recursos, quanto através de usos diversos e modificações, com o objetivo de suprir necessidades humanas.

Essas modificações frequentemente aceleram os processos naturais (como erosão, movimentos de massa gravitacionais, entre outros), e alteram a dinâmica e as condições físicoquímicas das águas e dos materiais geológicos, levando-os a níveis além dos limites de resiliência de cada componente ambiental. Essas áreas, que apresentam modificações acima desses limites, são consideradas degradadas, e objetos de ações visando a recuperação, em diferentes níveis.

Dentre essas áreas, as degradadas por processos erosivos são consideradas entre as mais frequentes, e que provocam perdas significativas em cadeia, atingindo a população em termos econômicos, sociais e ambientais.

No Brasil, os processos erosivos são diversificados e intensos, sendo que no estado de São Paulo existem pelo menos 40000 áreas consideradas degradadas por erosão, estando, grande parte, inserida em áreas urbanas.

Os procedimentos utilizados para a recuperação de áreas degradadas por erosão são inúmeros, porém a eficiência dos mesmos é questionável. Muitas vezes estes envolvem altos custos de implantação e não alcançam os resultados desejáveis, indicando a falta de estudos quanto à eficiência das medidas de recuperação; justificando-se assim esse trabalho.

Nesse contexto, o presente trabalho tem como principal objetivo estudar diferentes áreas degradadas por erosão, nas quais foram adotadas diferentes medidas de prevenção, controle e recuperação; com o objetivo de avaliar seus sucessos, fracassos e adequabilidade. 


\section{REVISÃO BIBLIOGRÁFICA}

\subsection{Erosão}

A palavra erosão surgiu do latim, derivada do verbo erodere, que significa desgastar, escavar. O termo erosão foi inicialmente utilizado na geologia para descrever a formação de depressões pela água corrente, que age desgastando os materiais sólidos (PENCK, 1894 apud ZACHAR, 1982).

A erosão do solo é definida por Ellison (1974) como um processo de desagregação das partículas do solo, sendo deflagrada por diferentes agentes erosivos. A segunda fase do processo erosivo, que ocorre após a desagregação, consiste no transporte das partículas, e por último a deposição.

Em geral, distinguem-se duas formas de abordagem para os processos erosivos: erosão natural ou geológica e erosão acelerada. El Swaify, Dangler e Armstrong (1982) indicam que a erosão natural se desenvolve em condições de equilíbrio com a formação do solo. Por outro lado, associam a erosão acelerada com a atividade antrópica, sendo esta configurada, a partir do momento em que as taxas de erosão excedem às de formação do solo, o que dá início ao processo de perda de produtividade, e leva à sua degradação. Lal (1990) complementa afirmando que a erosão natural não afeta o solo e o meio ambiente de forma negativa, e constitui-se um processo lento e construtivo, que resulta no desgaste de montanhas, e na formação de planícies.

\subsubsection{Classificação dos Agentes Erosivos}

Ayres (1936) cita a água, o vento e o gelo como sendo as três forças erosivas mais ativas. Segundo Lal (1990), os diferentes tipos de erosão do solo podem ser classificados com base nos principais agentes erosivos, sendo o vento, as gotas de chuva, e a água de escoamento superficial os principais agentes deflagradores do processo erosivo em áreas de cultivo e nos trópicos. Enquanto que o gelo é um agente erosivo relevante em latitudes do extremo norte, e em altitudes muito elevadas. 
Zachar (1982) afirma que a erosão eólica ocorre principalmente em áreas com escassez de precipitação, associado à predominância de altas temperaturas. Esse tipo de erosão pode afetar o solo, as rochas e minerais que estejam em contato com vento. Esses materiais são desgastados por partículas de solo carregadas pelo vento ou outro tipo de material sólido, configurando um processo abrasivo.

A erosão glacial, como foi mencionada por Zachar (1982), é predominante em regiões frias, com temperaturas abaixo de $0^{\circ} \mathrm{C}$. Esse fenômeno se dá pela ação de uma grande massa de gelo que se move lentamente. Nesse caso o solo é afetado apenas nas bordas da massa de gelo, onde surgem novos canais, com um fluxo de água e gelo derretido. Em contrapartida, a erosão causada pela neve atua no solo através de canais formados por avalanches, onde a grande pressão e velocidade da neve arrastam o solo ao longo da encosta, levando à formação de sulcos.

A erosão hídrica contempla a destruição da superfície da terra pela ação das gotas de chuva, pela água fluvial, pela água subterrânea e por águas não fluviais (ZACHAR, 1982). De acordo com Gray e Sotir (1995), o fenômeno conhecido por "splash", é resultado do impacto direto das gotas da água da chuva nas partículas do solo, ou em finas camadas que recobrem a superfície. Enquanto que a erosão fluvial ou marginal consiste na remoção do solo das margens e/ou no transporte de sedimentos ao longo de um canal. Pode-se ainda ocorrer erosão em subsuperfície, onde a água subterrânea cria um fluxo em direção a uma superfície livre, como uma voçoroca ou um talude, configurando o fenômeno de piping, ou de erosão em túnel.

Outro tipo de erosão hídrica, de acordo com Zachar (1982), é causado pela precipitação que resulta no escoamento superficial em encostas, também podendo ser chamada de erosão pluvial. E há ainda a erosão marítima ou costeira, causada pela ação das ondas do mar que se chocam contra a linha da costa (LAL, 1990).

Conhecido o fato que em regiões tropicais ou sub-tropicais úmidas, como o Brasil, os processos erosivos são provocados, principalmente, pela ação da chuva, justifica-se que, nesse trabalho, focalize-se os aspectos relacionados à erosão hídrica.

\subsection{Fatores Condicionantes da Erosão Hídrica}

Os fenômenos associados à geração desse tipo de erosão são comandados por dois conjuntos de fatores ou condicionantes principais: os fatores antrópicos, e os fatores naturais. Segundo o DAEE (1990), a ocupação Humana, iniciada pelo desmatamento e seguida pelo cultivo 
da terra, construção de estradas, criação e expansão das vilas e cidades, principalmente quando efetuada de forma inadequada, constitui fator decisivo na aceleração dos processos erosivos. Dada a presença de condições para o desenvolvimento de erosões aceleradas, o fenômeno erosivo passa a ser comandado por diferentes fatores naturais, sendo eles o clima, os tipos de solos e substrato rochoso, a topografia e a cobertura vegetal.

\subsubsection{Fatores Naturais}

\subsubsection{Chuva}

A gota de chuva e o escoamento superficial são considerados dois agentes erosivos distintos. Nishiyama (1995) afirma que, parte da erosividade da chuva, que segundo Zuquette (1987) é a capacidade de erosão da chuva; é conseqüência direta do impacto da gota, enquanto que a outra parte é conseqüente do escoamento superficial.

Lal (1990) considera a gota da chuva como o mais importante agente responsável pela iniciação da erosão difusa do solo. Esta, ao atingir a superfície desprotegida do solo, desloca as partículas de sua posição original, pelo processo conhecido como splash, que se refere à saltação de partículas juntamente com as gotas de chuva. De acordo com Guerra (2010), o fenômeno do splash varia tanto com a resistência do solo ao impacto das gotas de água, quanto com a própria cinética das gotas de chuva, ou seja, a ruptura dos agregados vai ocorrer com maior ou menor facilidade dependendo da energia impactada contra o solo.

Por sua vez, o escoamento superficial é considerado um importante agente de erosão, pois, ao mesmo tempo em que realiza o destacamento, transporta e deposita partículas do solo (LAL, 1990). De acordo com Ayres (1936) a quantidade, a intensidade, a duração e o tempo decorrido desde a chuva anterior, afetam diretamente a taxa do escoamento superficial resultante. Complementando o papel do escoamento superficial na erosão do solo, Morgan (1995) afirma que a quantidade de perda do solo, resultante desse processo, depende da velocidade e turbulência do fluxo, fatores que são função da quantidade de chuva, capacidade de infiltração e capacidade de retenção superficial.

Nesse aspecto, cita-se ainda o escoamento subsuperficial. Este, quando ocorre em fluxos concentrados, em túneis e dutos possui efeitos erosivos, que podem provocar o colapso da superfície situada acima, resultando na formação de voçorocas (GUERRA, 1998).

Porém, Guerra (1998), afirma que, apesar de o total pluviométrico ser utilizado em muitos estudos sobre erosão dos solos, esse parâmetro não é suficiente para prever a erosão. 
Apesar do conhecimento de que ocorre aumento da erosão, à medida que os totais de chuva aumentam, esse parâmetro deveria ser levado em conta apenas para dar uma idéia da relação entre chuva e erosão.

\subsubsection{Cobertura Vegetal}

Para Ayres (1936) o papel da vegetação na conservação do solo é de grande importância e se manifesta em diferentes aspectos. Em primeiro lugar a vegetação promove a dispersão direta, a interceptação e a evaporação das gotas de chuva através das folhagens das árvores e arbustos. O crescimento de uma vegetação densa funciona como um escudo protetor contra a violência do impacto da gota de chuva. Sob outro ponto de vista, a penetração das raízes através do perfil do solo resulta no surgimento de numerosas cavidades e tubos que promovem a infiltração. A melhoria da estrutura do solo pela adição de matéria orgânica, por sua vez, aumenta a absorção e dá condições ao solo de suportar um vigoroso crescimento vegetal. Outro benefício relacionado à cobertura vegetal consiste no aumento do atrito superficial, que contribuiu para a redução do volume do escoamento e diminuição da sua velocidade, assim como favorece o espalhamento lateral, evitando a concentração do fluxo.

Nesse contexto, Box Jr. e Bruce (1996) afirmam que determinadas coberturas do solo, são importantes na redução da erosão do solo causada pela água. Essas coberturas dissipam a energia do impacto das gotas de chuva, reduzindo a área passível de erosão. Em adição, práticas de gerenciamento da cobertura vegetal podem aumentar a atividade biológica, fornecendo estabilidade contra a erosão linear.

Os fatores relacionados à cobertura vegetal podem influenciar os processos erosivos de várias maneiras: através dos efeitos espaciais da cobertura vegetal, dos efeitos na energia cinética da chuva, e do papel da vegetação na formação de húmus, que afeta a estabilidade e teor de agregados (GUERRA, 1998).

Guerra (1998) afirma que a densidade da cobertura vegetal é fator importante na remoção de sedimentos, no escoamento superficial e na perda de solo. Afirma ainda, que o tipo e percentagem de cobertura vegetal podem reduzir os efeitos dos fatores erosivos naturais. Em uma área com alta densidade de cobertura, o escoamento e a erosão ocorrem em taxas baixas. Por outro lado, em áreas parcialmente cobertas pela vegetação, essas taxas podem aumentar rapidamente. Esse aumento está relacionado a solos com menos de $70 \%$ de cobertura vegetal e ocorre geralmente em áreas semi-áridas, agrícolas e de pastoreio. 
Nesse contexto, a vegetação desempenha um papel importante, pois promove uma distribuição mais difusa da água de escoamento pluvial, dificultando o processo erosivo (Souza, 2001).

\subsubsection{Relevo}

O relevo é um fator natural que atua na determinação da velocidade dos processos erosivos. De acordo com Ayres (1936), quanto maior a declividade do terreno, maior será a velocidade do escoamento e haverá menos tempo para a absorção da água pelo solo. A quantidade, ou volume, do escoamento também tem grande influência na erosão, sendo este determinado, em função do tamanho e formato área de contribuição; de modo que o comprimento de uma encosta é mais importante do que sua largura.

Além da declividade, o comprimento e o perfil das encostas são características que podem afetar a erodibilidade dos solos (RODRIGUES, 1982).

Em encostas com grandes comprimentos de rampa o escoamento superficial tem facilidade em se concentrar dado o percurso mais longo (RODRIGUES, 1982). Autores como Nishiyama (1998) e Infanti Jr. e Fornasari Filho (1998) confirmam que o aumento no comprimento de uma encosta leva ao aumento do volume de escoamento superficial e, consequentemente, produz um aumento da intensidade da erosão.

Quanto ao formato das encostas, o modelo proposto por Troeh (1965, apud Rodrigues 1982) define quatro tipos de vertentes que se caracterizam pela atuação de diferentes tipos de processos erosivos, como pode ser observado na Figura 1. 


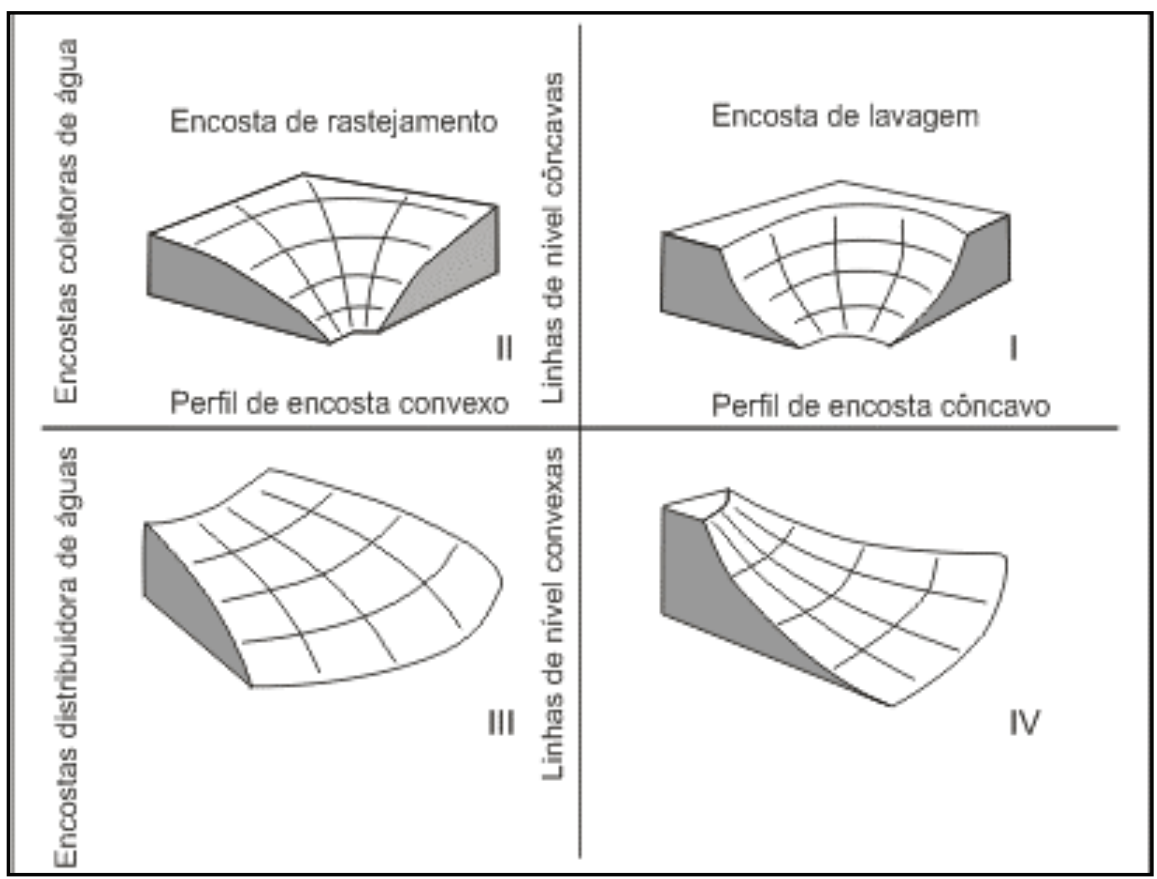

Figura 1: Formas de encostas (TROEH, 1965 apud RODRIGUES, 1982).

Ainda no que se refere ao formato das encostas, Ruhe (1975, apud XuJiongxin 1996) as considera como tridimensionais, representando a forma longitudinal e lateral da encosta pelo comprimento e largura, respectivamente, e em seguida os classifica como linear (L), côncavo (C) e convexo (V). A combinação das classificações do comprimento e da largura das encostas produz diversos tipos geométricos, conforme pode ser observado na Figura 2. O primeiro grupo compreende a forma co-linear (LL). O segundo abrange formas lineares em uma dimensão e curvas em outra: convexo-linear (VL), côncavo-linear (CL), linear-convexo (LV) e linear-côncavo (LC). E por fim, o terceiro grupo engloba as formas de dupla curvatura: convexo-convexo (VV), convexo-côncavo (VC), côncavo-convexo (CV) e côncavo-côncavo (CC). 


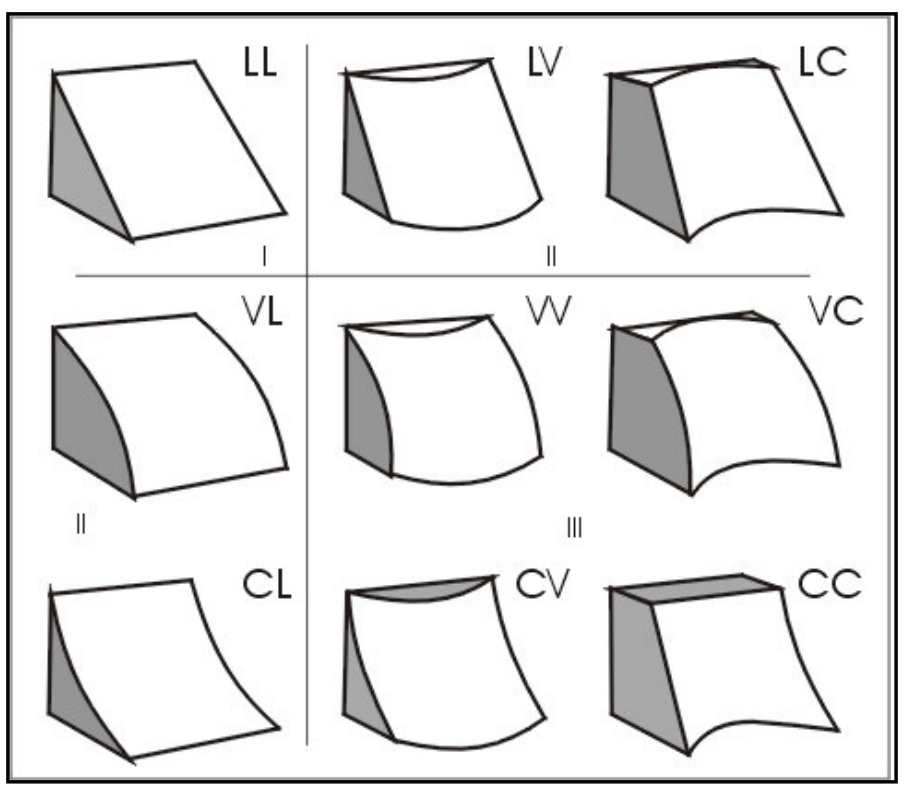

Legenda:

LL: forma co-linear

VL: convexo-linear

CL: côncavo-linear

$\mathrm{LV}$ : linear-convexo

LC: linear-côncavo

$\mathrm{VV}$ : convexo-convexo

VC: convexo-côncavo

CV: côncavo-convexo

CC: côncavo-côncavo

Figura 2: Formas geométricas das encostas. (RUHE, 1975, apud XUJIONGXIN, 1996).

Quanto às características associadas a essa classificação, XuJiongxin (1996) afirma que, no que se refere às encostas convexas no comprimento, a probabilidade do sedimento proveniente do topo da encostas se depositar é muito baixa, enquanto que a intensidade da erosão é mais acentuada. Por outro lado, nas encostas côncavas, devido ao declínio da velocidade do escoamento, a infiltração e a deposição de sedimentos é maior. Já no que se refere às características da largura das encostas, nas côncavas ocorre a concentração do escoamento, enquanto que nas convexas ocorre a dispersão, o que afeta a forma de ocorrência da erosão em cada caso. Quando o escoamento é concentrado, voçorocas podem se desenvolver mais facilmente, enquanto que no caso do escoamento divergente, as erosões laminar e linear por sulcos são dominantes.

Em suma, as características relativas à declividade, comprimento e forma das encostas atuam em conjunto entre si e com outros fatores relativos à erosividade da chuva, bem como às propriedades do solo, promovendo maior ou menor resistência à erosão (GUERRA, 1998).

\subsubsection{Solos}

Embora a resistência do solo à erosão dependa, em parte, da posição topográfica, da inclinação da encosta e da intensidade da perturbação, as propriedades do solo constituem o fator determinante. A predisponibilidade do solo ao destacamento e transporte das partículas é denominada erodibilidade do solo, e varia de acordo com a textura, estabilidade dos agregados, 
resistência ao cisalhamento, capacidade de infiltração e conteúdo orgânico e químico (MORGAN, 1995).

A textura do solo é a propriedade mais importante em muitas aplicações, sobretudo no estudo da erosão (TOY; FOSTER; RENARD, 2002). A distribuição do tamanho das partículas é importante no destacamento e no transporte das partículas do solo; assim como determina a força necessária para que esses processos ocorram (LAL, 1990). Nesse sentido Toy, Foster e Renard (2002) afirmam que a textura do solo é a propriedade mais importante no estudo da erosão. Para esses autores, solos ricos em argila são mais resistentes à ação erosiva da chuva, pois são resistentes ao destacamento das partículas, enquanto que os solos com grandes quantidades de areias são menos resistentes. Por outro lado, os solos ricos em areais produzem menos sedimento, pois o escoamento é minimizado pela infiltração, embora, esse tipo de solo possa ter suas partículas facilmente destacadas e transportadas por um escoamento não muito intenso. Em contrapartida, os solos de textura média, especialmente os ricos em silte, são os mais erodíveis, pois estes tendem a produzir escoamentos intensos, fato que se soma a facilidade com que suas partículas são destacadas e transportadas (TOY; FOSTER; RENARD, 2002).

Segundo Lal (1990) a estrutura do solo é definida de acordo com o arranjo geomecânico de partículas sob a forma de agregado, de forma que agregados maiores são mais resistentes à erosão. A estrutura de um solo envolve características como ligação entre as partículas do solo e resistência à dispersão pela água, porcentagem de agregados estáveis à água, peso médio do agregado, facilidade de interceptação da água da chuva e habilidade de propagar a água pelo perfil, proporção de macroporos, estabilidade e continuidade dos poros. Além das características relativas à estabilidade da estrutura do solo, a quantidade de material de cimentante (matéria orgânica, argila e óxidos) também é importante.

Em situações em que as taxas de chuva excedem a taxa de infiltração do solo, o solo se torna saturado, e se dá o acúmulo de água na superfície, até que se inicia o escoamento superficial (LAL, 1990). De acordo com Salomão e Iwasa (1995) a capacidade de infiltração das águas de chuva é outra importante propriedade relacionada ao solo, no que se refere à erosão. Para Morgan (1995) essa capacidade é influenciada pelo tamanho e estabilidade dos poros, e pelo perfil do solo. Solo com agregados estáveis mantém melhor os seus poros, enquanto que solos com argilas expansivas ou minerais instáveis em contato com a água tendem a diminuir a capacidade de infiltração. 
A resistência do solo ao cisalhamento é derivada do atrito entre suas partículas constituintes que são forçadas a deslizar umas contra as outras, absorvendo assim as tensões (MORGAN, 1995). Essa característica tem relevância no processo erosivo, pois determina o comportamento do solo frente ao escoamento da água (LAL, 1990).

A resistência do solo à ação dos agentes erosivos também é afetada pelos constituintes químicos do solo. O conteúdo de matéria orgânica afeta sua estrutura e estabilidade, de modo que quanto maior for sua fração no solo, menor é sua suscetibilidade à erosão (LAL, 1990). Segundo Salomão e Iwasa (1995), a matéria orgânica incorporada no solo permite maior agregação e coesão entre partículas, tornando o solo mais estável em presença de água, mais poroso e com maior poder de retenção de água. Quimicamente, a característica mais importante refere-se à quantidade de argilas dispersivas no solo (MORGAN, 1995). Weill e Pires Neto (2007) indicam a argila, os sesquióxidos de ferro e alumínio, os cátions bivalentes, que são agentes cimentantes, como estabilizantes da estrutura e agregadores do solo.

\subsubsection{Substrato Rochoso}

É importante caracterizar o substrato rochoso, pois este determina as características dos solos que se formam a partir dele, e também as características do relevo, que, por sua vez, são fatores que se relacionam diretamente aos processos erosivos (SELBY, 1993). Infanti Jr. e Fornasari Filho (1998), afirmam que as características litológicas do substrato rochoso, relacionadas à intensidade do intemperismo, e à natureza da alteração e grau de fraturamento condicionam a suscetibilidade do material à erosão.

Segundo os mesmos autores, as principais áreas de ocorrência de boçorocas no País estão associadas às áreas de ocorrência das formações geológicas sedimentares, cujas coberturas pedológicas correspondem a materiais arenosos.

\subsubsection{Fatores Antrópicos}

O Homem tem atuado como agente acelerador dos processos erosivos, de modo que, mesmo áreas naturalmente pouco suscetíveis têm apresentado sérios problemas de erosão, como resultado de atividades como desmatamento, movimentação de terra, atividades agrícolas e de mineração mal orientadas, entre outros (ROSA et al, 1981). 
Algumas atividades antrópicas podem ser citadas como as de maior influência para o desencadeamento da erosão. São elas, a ocupação desordenada de encostas e fundos de vale, a construção de barragens, os desmatamentos seguidos por queimadas e capinas, agricultura e pecuária descontroladas, abertura de valetas perpendiculares às curvas de nível; aberturas de estradas sem obras de drenagem, execução descuidada de loteamentos.

\subsection{Tipos de Erosão Hídrica}

De acordo com Bennett (1939, apud Zachar, 1982), o escoamento superficial das águas pluviais pode configurar dois tipos de erosão acelerada: a laminar e a linear. A primeira ocorre por escoamento difuso das águas da chuva, de forma que haja remoção progressiva de camadas superficiais do solo. Já a erosão linear é causada por concentração do fluxo das águas de escoamento superficial, podendo ser em forma de sulcos, ravinas ou voçorocas.

\subsubsection{Erosão Laminar}

De acordo com Ayres (1936) a erosão laminar ocorre logo depois do início da chuva, quando o excesso de água começa a escoar pela encosta, carregando solo e matéria orgânica. Segundo o autor, é necessário que o escoamento se dê de forma homogênea em toda a área, de modo que a mistura do solo e do excesso de água aumente em espessura progressivamente, e se mova em forma de uma fina lâmina do topo até a base da encosta, em velocidade suficiente para erodir.

De acordo com Beasley (1972), a erosão laminar remove as partículas mais leves do solo, a matéria orgânica, e os nutrientes solúveis, constituindo assim um sério dano para a manutenção da fertilidade do solo.

Infanti Jr. e Fornasari Filho (1998) complementam que a erosão laminar, decorrente do escoamento superficial disperso, resulta na remoção progressiva e uniforme dos horizontes superficiais do solo. De acordo com Guerra (1998), essa forma de escoamento ocorre sob condições de chuva prolongada, quando a capacidade de armazenamento de água no solo se satura. Dessa forma, a capacidade de infiltração é excedida, e começa a ocorrer o escoamento. Quanto maior a turbulência do fluxo de água, maior a capacidade erosiva gerada por esse fluxo. 


\subsubsection{Erosão Linear}

De acordo com Ayres (1936), devido às condições do solo no campo, onde aspectos como a textura não são perfeitamente uniformes, a água do escoamento superficial tende a se concentrar em pequenos canais. Nos casos em que as encostas são longas o suficiente esses canais podem evoluir para valas, configurando assim a erosão linear. As incisões resultantes desse processo podem ocorrer na forma de sulcos, ravinas ou voçorocas (INFANTI JR. e FORNASARI FILHO, 1998).

A erosão em sulco (Figura 3 ) consiste em pequenas incisões na superfície terrestre em forma de filetes muitos rasos. Ocorrem, geralmente, em áreas onde a erosão laminar é mais intensa. Apresentam uma profundidade e largura inferior a 50 centímetros (FERREIRA, 2004). Alguns autores como Ayres (1936), Beasley (1972), Lal (1990) e Grissinger (1996), consideram os sulcos como pequenos canais, bem definidos, que concentram o escoamento superficial, e que podem ser eliminados com práticas agrícolas convencionais. Em termos de dimensões, de acordo com Ferreira (2004), os sulcos apresentam profundidade e largura inferior a 50 centímetros.

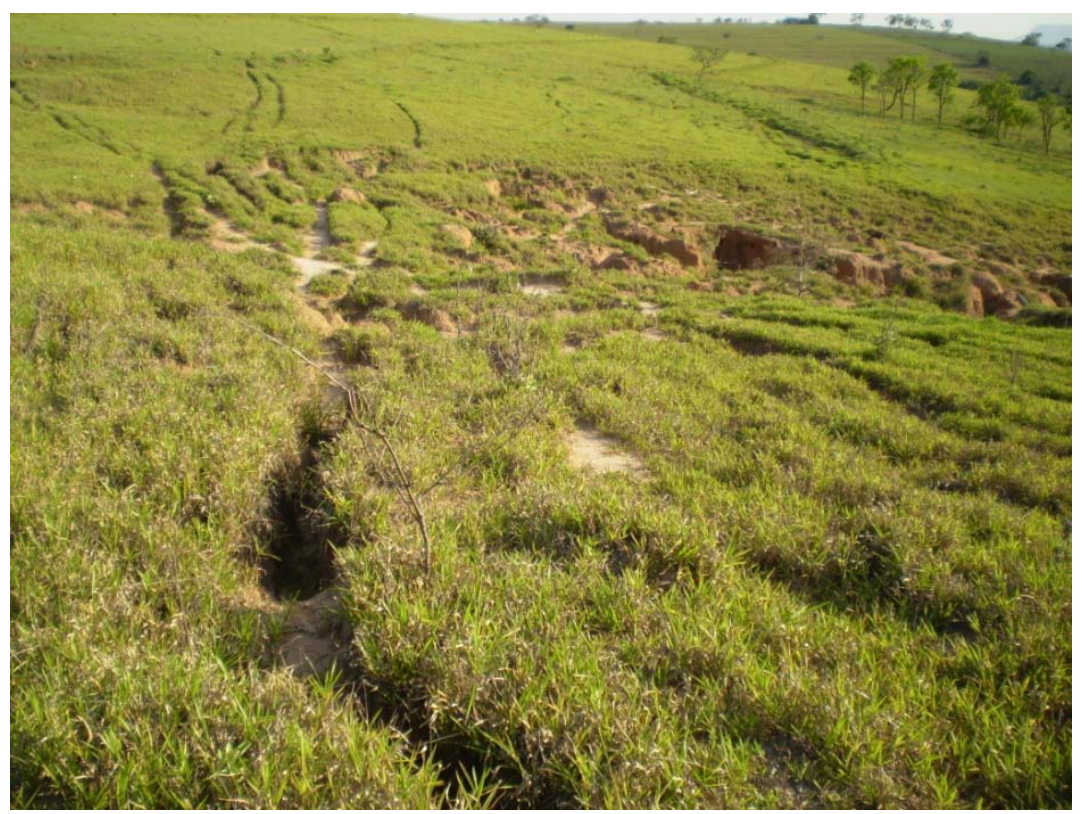

Figura 3: Erosão por sulcos em área de pastagem em Corumbataí, São Paulo, Brasil.

Ridente Júnior (2000, apud Yamanouth, 2003) considera as ravinas (Figura 4) como produto do escoamento superficial concentrado, que forma as feições erosivas lineares. Para o 
referido autor, a erosão em ravina é considerada de grande porte com largura superior a 1 metro, e profundidade superior a 0,5 metro.

As ravinas são normalmente iniciadas a uma distância crítica do topo da encosta, onde o escoamento superficial se torna canalizado. Elas podem ser próximas à base das encostas, onde uma pequena incisão recua em direção ao topo. Normalmente, os sistemas de ravinas são classificados como descontínuos, ou seja, não têm nenhuma ligação com a rede de drenagem fluvial (GUERRA, 1998).

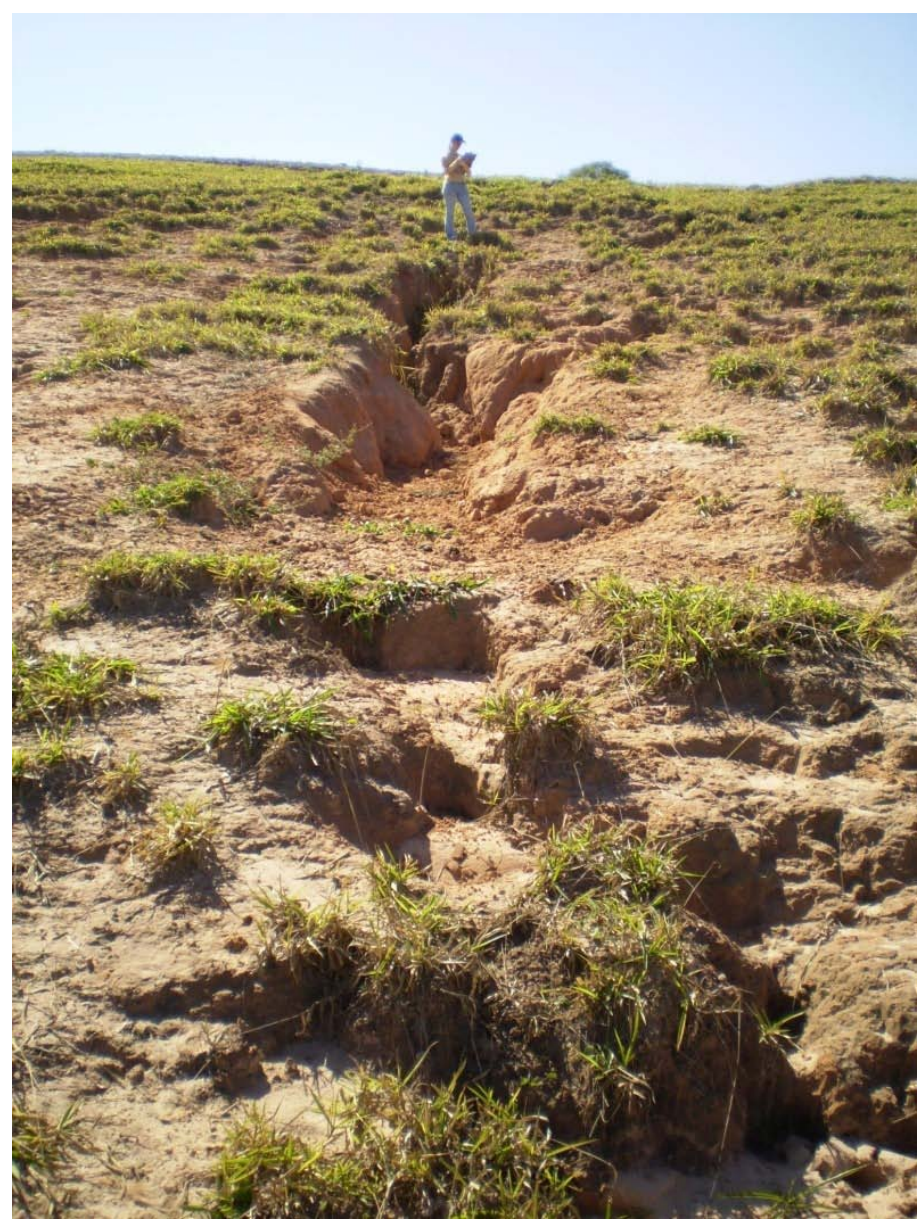

Figura 4: Erosão por ravina em área de pastagem no Município de Corumbataí, São Paulo, Brasil.

Para Ayres, as voçorocas (Figura 5) se configuram quando o processo erosivo evolui de tal maneira a formar um canal bem definido, envolvendo uma grande aceleração na degradação, e consequentemente perdas econômicas. Nesse ponto a recuperação e controle tornam-se muito difíceis. Guerra (1998) caracteriza ainda as voçorocas como feições erosivas relativamente permanentes nas encostas, possuindo paredes laterais íngremes e, em geral, fundo chato, 
ocorrendo fluxo de água no seu interior durante os eventos chuvosos, podendo esta se aprofundar tanto a ponto de atingir o lençol freático.

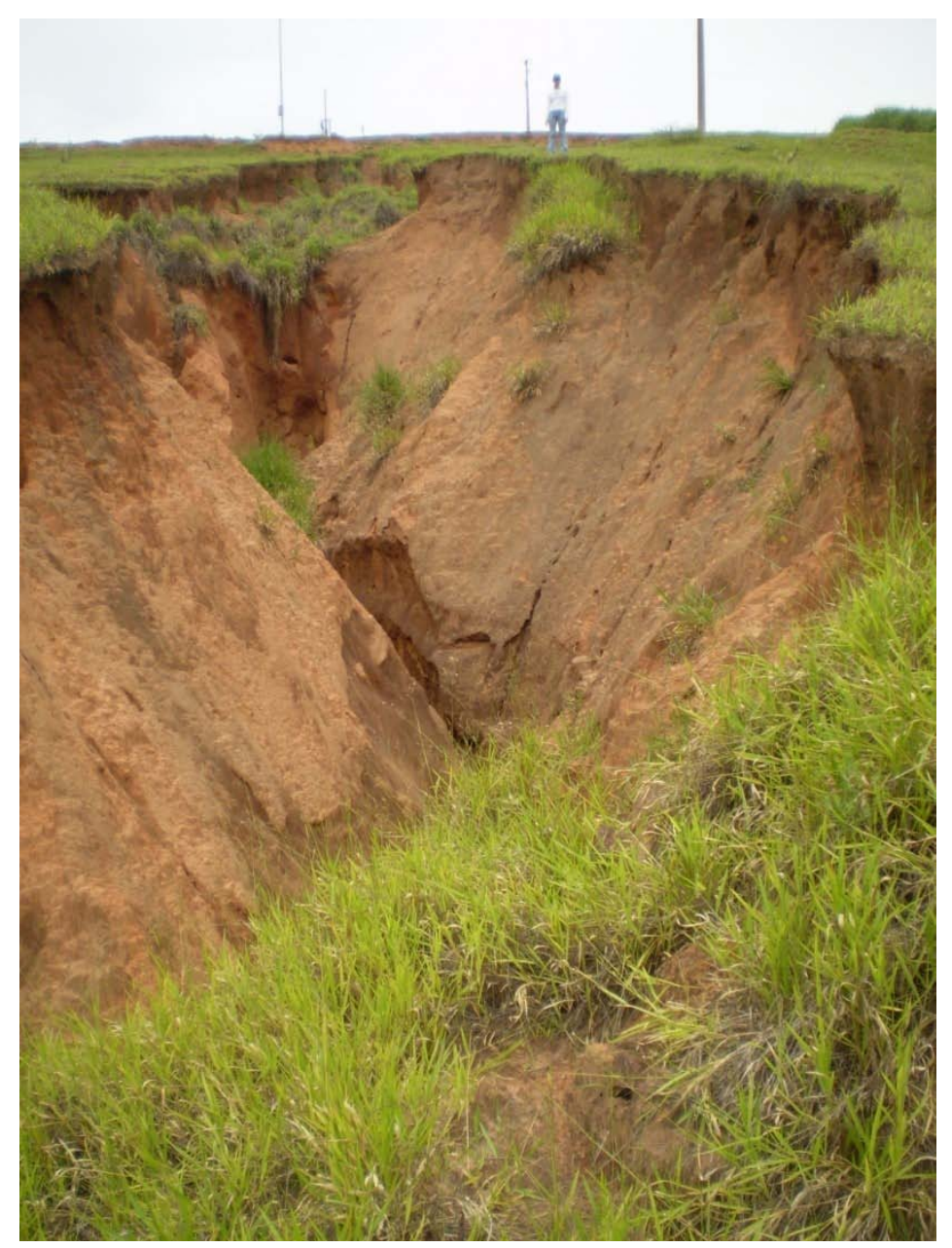

Figura 5: Erosão por voçoroca em área de pastagem no Município de Corumbataí, São Paulo, Brasil.

De acordo com Beasley (1972), uma voçoroca ocorre quando um canal superficial (sulcos e ravinas) foi erodido de forma que este não pode mais ser suavizado por práticas agrícolas convencionais. Para Morgan (1995), as voçorocas são canais íngremes relativamente permanentes que apresentam escoamento efêmero durante eventos chuvosos. São caracterizadas por possuir uma cabeceira e vários pontos de mudança brusca de inclinação, alternando seções de gradiente suave e perfis retos ou ligeiramente convexos. Apresentam ainda grandes profundidades e pequenas larguras, quando comparadas a canais regulares; e transportam grandes quantidades de sedimento.

Outro tipo de manifestação da erosão linear é o piping (Figura 6) ou erosão em túnel, que é causada pelo escoamento subsuperficial, ou em túnel, que age removendo e 
transportando as partículas de solo. Esse tipo de escoamento se inicia através de rachaduras, sulcos ou tocas de animais, promovendo uma rede de macroporos para rápida transmissão do fluxo (LAL, 1990). Selby (1993) complementa, que os fatores associados à ocorrência de erosão por piping são: a ocorrência de chuvas sazonais ou muito variáveis; solos sujeitos à rachaduras em períodos de seca; redução da cobertura vegetal; existência de uma camada relativamente impermeável no perfil do solo; existência de um gradiente hidráulico no solo; e existência de uma camada de solo dispersível.

De acordo com Guerra (1998), os dutos ou pipes são grandes canais abertos em subsuperfície, variando de poucos centímetros a vários metros de diâmetro. Em alguns casos, a evolução do piping pode resultar no colapso do solo situado a cima, o que pode contribuir para o surgimento de voçorocas. Esse tipo de feição é comumente encontrado nas paredes de grandes voçorocas, contribuindo para a evolução das mesmas.

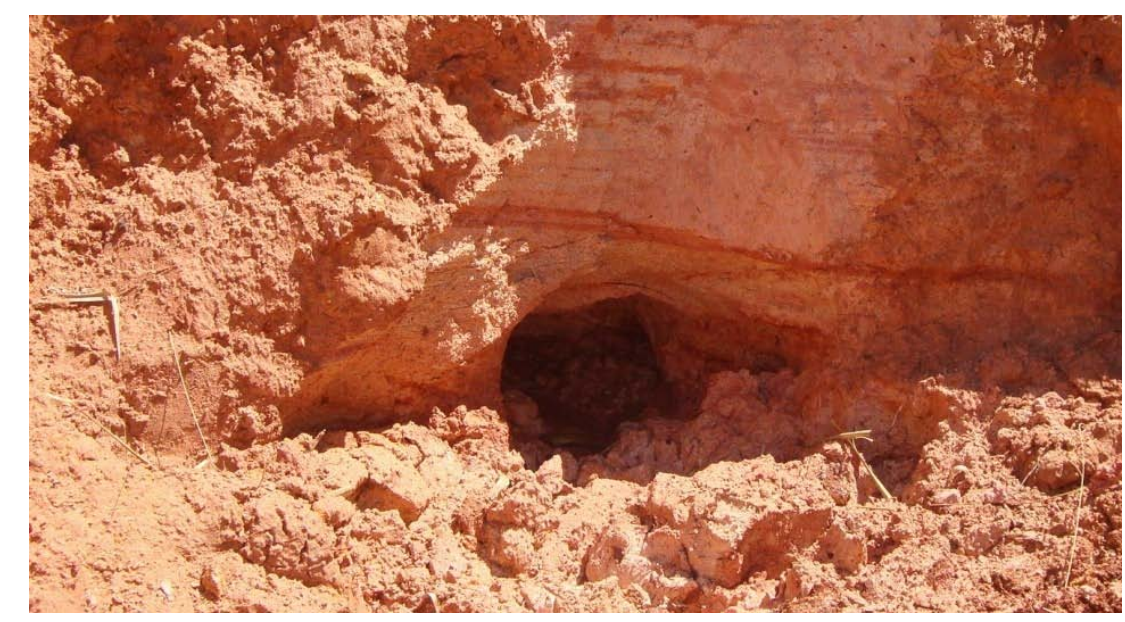

Figura 6: Erosão em piping no Município de Casa Branca, São Paulo, Brasil.

A erosão marginal, por sua vez, ocorre nas margens ou no fundo dos canais, sendo que esta última ocorre quando a inclinação ou o volume do escoamento são intensos. Mas a erosão das margens é a forma mais comum, sendo notada principalmente no começo das curvas de um rio meandrante (AYRES, 1936).

\subsection{Aspectos relacionados à degradação e recuperação}

A ABNT (1989) define degradação do solo como sendo um estado em que as características do solo são alteradas de forma adversa, em relação aos seus diferentes usos 
possíveis, tanto o estabelecido em planejamento quanto aos potenciais. Sobre esse significado, Bitar e Braga (1995), afirmam que este corresponde a uma situação de degradação motivada por diferentes tipos de intervenção no meio físico.

Lal (1990) afirma que a degradação do solo é um termo bastante abrangente, que implica o declínio da qualidade do solo devido à deterioração das propriedades físicas, químicas e biológicas do mesmo. $\mathrm{O}$ autor considera, nesse contexto, a erosão acelerada como sendo um processo que leva a degradação do solo.

Para Barrow (1991), a degradação do solo deve ser definida como a perda da utilidade, ou ainda como a redução ou modificação das características ou dos organismos, sem que estes possam ser substituídos. Para o referido autor esse conceito implica que a degradação ocorre até mesmo quando envolve a modificação para uma composição mais simples de flora ou fauna; ou a substituição de uma forma orgânica por outra inferior.

Blum (1997), por sua vez, define degradação do solo como a perda ou a redução das funções e dos usos do solo. Para ele, a degradação do solo pode ser um processo natural, causado pela ação do intemperismo; ou então pode ser causada pela ação antrópica, especialmente pelo uso diverso do solo. Segundo o autor, por uma breve análise histórica do uso do solo, pode-se ver que a principal interferência Humana, que levou à degradação do solo, foi através da remoção da cobertura vegetal das diferentes áreas, mas especialmente de florestas, para a implantação de sistemas agrícolas (plantações e pastagens), o que resultou em uma grande perda de sedimentos devido à erosão do solo, que podem ser encontrados depositados em rios e lagos.

Em contrapartida, Sánchez (2006) afirma que quando um ambiente é afetado pela ação humana ele pode ser recuperado mediante diferentes ações. Essas ações podem envolver medidas de melhoria do meio físico, como por exemplo, da condição do solo, a fim de restabelecer a vegetação ou a qualidade da água, e, consequentemente, as comunidades bióticas. E ainda, pode envolver medidas de manejo dos elementos bióticos do ecossistema, como o plantio de mudas de espécies arbóreas ou a reintrodução da fauna. Desse modo, o conceito de recuperação ambiental designa a aplicação de técnicas de manejo visando tornar um ambiente degradado apto para um novo uso produtivo, desde que sustentável.

No contexto do meio físico, a ABNT (1989) define recuperação do solo como sendo um processo de manejo do solo, no qual são criadas condições para que uma área natural ou perturbada, seja adequada a novos usos. Por outro lado, existem variantes da recuperação, que são diferenciadas em restauração e reabilitação. 
A abordagem da ABNT (1989), focada no meio físico, considera restauração como a recomposição de um solo de modo a reproduzir as condições exatas existentes antes de sua perturbação. Para Blum (1997), a restauração do solo só é possível quando há o conhecimento exato sobre os processos que levaram à degradação, e sobre quão avançado o processo se tornou ao longo do tempo. Segundo o mesmo, a restauração da degradação causada por processos erosivos, por exemplo, só é possível quando o solo alcança estabilidade, de modo que uma nova interferência na área irá causar apenas um novo processo erosivo. E ainda, segundo Sánchez (2006) restauração envolve o retorno das condições existentes antes da degradação.

A reabilitação, contudo, é uma modalidade mais frequente de recuperação, e envolve a adequação de uma área perturbada a um uso determinado e novo ao anterior à perturbação, segundo um projeto pré-determinado, e adequado as condições do ambiente em que será inserido (ABNT, 1989). No que se refere às características do solo, a reabilitação melhora suas propriedades, mas sem alcançar os níveis originais (BLUM, 1997).

\subsection{Medidas de Controle de Erosão Pluvial}

\subsubsection{Objetivos}

De acordo com Morgan (1995), a erosão deve ser controlada, em longo prazo, para prevenir a deterioração da qualidade do solo, impedindo que este atinja uma situação em que não possa ser recuperado, o que impediria opções para usos futuros. Mas, dado que a erosão é um processo natural, ela não pode ser evitada, de modo que as abordagens de prevenção devam atuar de modo a reduzir suas taxas a níveis aceitáveis de perda de solo.

As estratégias para conservação do solo, ou controle de erosão, se baseiam em alguns aspectos específicos, citados por vários autores. Ayres (1936) aponta que as medidas de controle de erosão têm como objetivo aumentar a absorção da água de escoamento através de melhoras nas taxas de infiltração tanto no momento em que a chuva cai, quanto aumentando o tempo de contato durante o escoamento. Lal (1990) complementa esse conceito, afirmando que o controle efetivo da erosão consiste na redução do impacto das gotas de chuva, no aumento da resistência do solo ao cisalhamento, e na diminuição da força cisalhante dos fluidos erosivos. Morgan (1995) considera como principais abordagens para controle da erosão as medidas citadas tanto por Ayres (1936) quanto por Lal (1990). Laflen e Roose (1997) acrescentam mais 
um ponto à lista citando a indução à deposição dos materiais destacados como mais uma técnica de controle da erosão. E finalmente, Unger (1996) complementa a idéia de Ayres (1936), citando que as técnicas relacionadas ao escoamento superficial devem, além de reduzir seu volume através do aumento de sua infiltração, minimizar os impactos negativos conseqüentes da sua ocorrência.

Muitos autores apresentam abordagens distintas para a erosão em áreas urbanas e em áreas rurais, no que se refere às medidas de controle de erosão. Nas áreas agrícolas os processos erosivos podem ser controlados através da adoção de práticas conservacionistas, que geralmente visam a máxima infiltração e o menor escoamento superficial (SALOMÃO e YWASA, 1995). A escolha da técnica a ser aplicada deve se adaptar às características físicas e químicas do solo, às características das encostas, e ao tipo de uso da terra (SALOMÃO, 2010).

Por outro lado, nas áreas urbanas, assim como nas rurais, o surgimento da erosão está associado à falta de planejamento, ou seja, a ocupação se dá sem levar em consideração aspectos como as particularidades do meio físico, as condições sociais e econômicas, e as tendências do desenvolvimento (SALOMÃO e YWASA, 1995). Nesse contexto, o objetivo das medidas de controle da erosão urbana deve se basear em manter a integridade física das cidades, de modo que a escolha das técnicas a serem adotadas deve variar de acordo com as necessidades de cada local (GALERANI et al 1995).

Essa diferenciação entre erosão urbana e rural é facilmente observada quando se analisa as classificações dos métodos de controle de erosão propostas por diversos autores. Muitas das classificações existentes estão normalmente associadas aos diferentes tipos de medidas relativas ao controle da erosão rural, como é o caso das classificações sugeridas por Lal (1990), Morgan (1995) e Salomão e Ywasa (1995).

A classificação proposta por Lal (1990) considera que, as técnicas que se baseiam no controle do impacto das gotas de chuva no solo são, em sua maioria, técnicas vegetativas ou biológicas. E que as técnicas agrícolas e de engenharia são utilizadas para diminuir a velocidade e a força cisalhante do escoamento.

Morgan (1995), por sua vez, divide as várias técnicas de conservação do solo em três grupos principais: as agrícolas, as de manejo do solo e as mecânicas. Segundo o autor, as técnicas agrícolas se baseiam na proteção do solo contra a erosão proporcionada pela vegetação. As técnicas de manejo consistem em maneiras de preparar o solo para promover o crescimento vegetal, melhorando sua estrutura, de modo que o torne mais resistente a erosão. $\mathrm{E}$ 
finalmente, as técnicas mecânicas ou físicas envolvem estruturas de engenharia que se baseiam na manipulação da superfície topográfica para controlar a ação do escoamento.

Salomão e Iwasa (1995) apontam que as técnicas de conservação do solo, adotadas na agricultura, são divididas em vegetativas, edáficas e mecânicas. Os autores consideram que as técnicas vegetativas utilizam a cobertura vegetal como critério de contenção da erosão. As edáficas abrangem as práticas conservacionistas que mantêm ou melhoram as condições de fertilidade do solo e que, indiretamente, controlam a erosão. E por último, as mecânicas englobam as práticas artificialmente desenvolvidas nas áreas de cultivo, cuja finalidade é controlar o escoamento superficial das águas e facilitar a sua infiltração.

Em relação às medidas de controle de erosão comumente empregadas nas áreas urbanas, não há uma classificação ou agrupamento específico. Para Galerani et al. (1995), os métodos adotados para controlar a erosão urbana variam de acordo com as necessidades de cada local, podendo envolver desde soluções individuais até soluções de grande porte, que abrangem obras de micro e macrodrenagem, contenção de taludes entre outras. Fendrich (1997), por sua vez, afirma que não existe uma única metodologia a ser aplicada, e que para cada caso deve ser utilizada uma técnica específica, determinada de acordo com as condições do uso, do meio físico e dos recursos disponíveis.

Gray e Sotir (1995) por sua vez, tratam de técnicas de proteção e controle da erosão em encostas, que podem ser aplicadas tanto em áreas rurais quanto em áreas urbanas. Segundo os autores as três principais categorias são as de construção viva, que tradicionalmente usam grama ou outras plantas vivas para controle da erosão primária; de construção inerte, que usam estruturas ou sistemas mecânicos inertes; e de construção mista, que abrange os métodos de bioengenharia e biotecnologia.

\subsubsection{Principais tipos de medidas}

As diferentes medidas existentes para controle da erosão, tanto para áreas rurais quanto para áreas urbanas, são tratadas por diversos autores em trabalhos internacionais como os de Ayres (1936), Zachar (1982), FAO (1986), Lal (1990) Morgan, Quinton e Rickson (1994) e Morgan (1995). No Brasil, se destacam os trabalhos realizados por DAEE (1989), Bertoni e Lombardi Neto (1993), Bidone e Tucci (1995), Salomão e Iwasa (1995), Fendrich (1997a, b), Obladen (1997); Righetto (1998) e Ridente Jr. et al. (1999), e Souza (2001). Pela análise da extensa bibliografia que abrange esse tema, foi possível perceber que algumas técnicas são abordadas com maior 
frequência, dada a sua facilidade de implantação e qualidade dos resultados obtidos. Essas técnicas foram reunidas e agrupadas, com base nos conceitos tratados anteriormente, em cinco grupos distintos: técnicas mecânicas, ecológicas, estruturais, agrícolas e de bioengenharia. Neste trabalho, foi considerado que as técnicas mecânicas constituem práticas artificiais, que depositam porções de solo de forma adequada, objetivando diminuir a velocidade do escoamento superficial e aumentar a infiltração. As técnicas ecológicas, no entanto, são as que utilizam apenas componentes vegetais para conter o processo erosivo. As técnicas estruturais englobam as metodologias que utilizam elementos mecânicos e estruturais, com diferentes finalidades dentro do cenário erosivo. As técnicas agrícolas tratam das técnicas conservacionistas do solo, associadas com esse tipo de atividade. E finalmente, as técnicas de bioengenharia utilizam materiais vivos, especialmente vegetação, em conjunto com elementos mecânicos e estruturais.

Os diferentes tipos de técnicas de controle de erosão podem ser utilizados com diferentes objetivos, ou seja, podem ser empregadas visando prevenir, controlar, mitigar ou recuperar uma área, frente à ação erosiva da água. A diferenciação entre os objetivos, adotada nesse trabalho, considera como atividades de prevenção aquelas que envolvam técnicas que buscam evitar a ocorrência do processo erosivo, impedindo a ação do agente deflagrador, ou diminuindo a vulnerabilidade dos fatores condicionantes da erosão. As atividades de controle, por sua vez, atuam de modo a impedir a evolução da erosão já existente, sobre qualquer circunstância, diminuindo a ação do deflagrador ou diminuindo a vulnerabilidade, mas sem alterar o estado atual da feição erosiva. O conceito de mitigação é adotado quando um grupo de técnicas é empregado visando à redução ou eliminação de algum impacto negativo relacionado à erosão, como por exemplo, quando se deseja evitar o transporte dos sedimentos destacados para o corpo d'água. E finalmente, a recuperação de um processo erosivo é considerada como a eliminação total das feições existentes e das condições de vulnerabilidade. O processo de recuperação da erosão pode envolver tanto ações que levem à reabilitação de um dado local, instituindo neste um uso diferente do prévio à degradação erosiva; quanto pode envolver ações que restituam as condições naturais e o uso anterior, constituindo assim uma situação de restauração.

Desse modo, as técnicas de controle de erosão mais abordadas pelos diferentes autores foram identificadas, e agrupadas de acordo com o tipo, e ainda classificadas quanto ao objetivo com que podem ser empregadas, de acordo com as definições tratadas anteriormente. 0 resultado dessa classificação pode ser observado na Tabela 1. 
Tabela 1: Classificação, quanto ao tipo, das principais medidas de prevenção, controle, mitigação e recuperação de erosão.

\begin{tabular}{|c|c|c|c|c|c|}
\hline & \multirow[b]{2}{*}{ Medidas } & \multicolumn{4}{|c|}{ Objetivo das Medidas } \\
\hline & & Prevenção & Controle & Mitigação & Recuperação \\
\hline \multirow{5}{*}{ 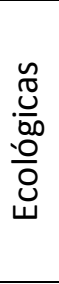 } & Revegetação & $x$ & $x$ & $x$ & $x$ \\
\hline & Pastagem & $x$ & $x$ & $x$ & $x$ \\
\hline & Faixa ripariana & $x$ & $x$ & $x$ & $x$ \\
\hline & Zonas de buffer & $x$ & $x$ & $x$ & $x$ \\
\hline & Barreira de galhos (Brush barrier) & $x$ & $x$ & $x$ & \\
\hline \multirow{13}{*}{$\frac{\frac{n}{\pi}}{\frac{0}{0}}$} & Plantas de cobertura & $x$ & $x$ & $x$ & \\
\hline & Culturas em faixa & $x$ & $x$ & $x$ & \\
\hline & Cordões de vegetação permanente & $x$ & $x$ & $x$ & \\
\hline & Faixas de bordadura & $x$ & $x$ & $x$ & \\
\hline & Alternância de capinas & $x$ & $x$ & $x$ & \\
\hline & Ceifa do mato & $x$ & $x$ & $x$ & \\
\hline & Cobertura morta & $x$ & $x$ & $x$ & \\
\hline & Controle do fogo & $x$ & & & \\
\hline & Adubação (verde, química e orgânica) & $x$ & $\mathrm{x}$ & $x$ & \\
\hline & Plantio Direto & $\mathrm{x}$ & $x$ & $\mathrm{x}$ & \\
\hline & Rotação de culturas & $x$ & $x$ & $x$ & \\
\hline & Calagem & & & $x$ & \\
\hline & Plantio em contorno & $x$ & $x$ & $x$ & $x$ \\
\hline \multirow{13}{*}{ 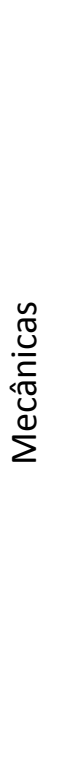 } & Terraceamento & $x$ & $x$ & $x$ & $x$ \\
\hline & Sulcos e camalhões em contorno & $x$ & & & \\
\hline & Canais escoadouros & $x$ & $\mathrm{x}$ & $x$ & \\
\hline & Barragens & $x$ & $x$ & $x$ & \\
\hline & $\begin{array}{l}\text { Adequação e conservação de estradas } \\
\text { vicinais e carreadores }\end{array}$ & $x$ & $x$ & $x$ & \\
\hline & Caixas de infiltração & $x$ & $x$ & $x$ & \\
\hline & Aterramento & & $x$ & $x$ & $x$ \\
\hline & Rip rap & $x$ & $\mathrm{x}$ & $\mathrm{x}$ & $x$ \\
\hline & Cordões de nível & $x$ & $x$ & $x$ & $x$ \\
\hline & Aterramento com resíduo & & $x$ & $x$ & $x$ \\
\hline & Retaludamento & $x$ & $x$ & $x$ & $x$ \\
\hline & Bermas & $x$ & $x$ & $x$ & $x$ \\
\hline & Barragem de Sedimento & $x$ & $x$ & $x$ & \\
\hline
\end{tabular}


Continuação da Tabela 1.

\begin{tabular}{|c|c|c|c|c|c|c|}
\hline & \multirow[b]{2}{*}{ Medidas } & \multicolumn{4}{|c|}{ Objetivo das Medidas } \\
\hline & & & Prevenção & Controle & Mitigação & Recuperação \\
\hline \multirow{24}{*}{ 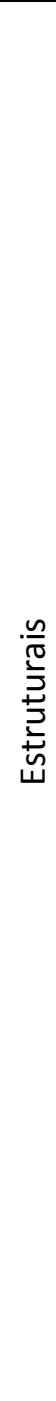 } & 1 & Muro de contenção & $x$ & $x$ & $x$ & \\
\hline & 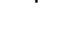 & Dique de Proteção & $x$ & $x$ & $x$ & \\
\hline & & Meios-fios/Guias & $x$ & $x$ & $x$ & $x$ \\
\hline & $\varepsilon$ & Sarjetas & $x$ & $x$ & $x$ & $x$ \\
\hline & 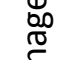 & Bocas-de-Lobo/Bocas coletoras & $x$ & $x$ & $x$ & $x$ \\
\hline & $\frac{\bar{\nu}}{\bar{\nu}}$ & Galerias & $x$ & $x$ & $x$ & $x$ \\
\hline & 을 & Poços de visita & $x$ & $\mathrm{x}$ & $x$ & $x$ \\
\hline & & Tubos de ligações & $x$ & $\mathrm{x}$ & $x$ & $x$ \\
\hline & & Caixas de ligação & $x$ & $x$ & $x$ & $x$ \\
\hline & \multirow{15}{*}{ 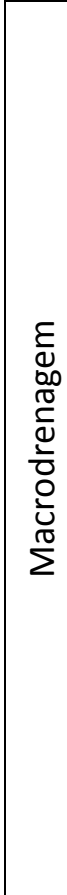 } & Canais: naturais ou artificiais & $x$ & $x$ & $x$ & $x$ \\
\hline & & Dissipadores de energia & $x$ & $x$ & $x$ & $x$ \\
\hline & & Ressalto Hidráulico: Canais abertos & & $x$ & $x$ & $x$ \\
\hline & & - Tipo SAF para $n^{\circ}$ Froude 1,7 a 17 & & $\mathrm{x}$ & $\mathrm{x}$ & $x$ \\
\hline & & - Tipo USBR II para ${ }^{\circ}$ Froude $\geq 4,5$ & & $x$ & $x$ & $x$ \\
\hline & & - Tipo USBR III para $n^{\circ}$ Froude $\leq 4,5$ & & $x$ & $x$ & $x$ \\
\hline & & - Tipo USBR IV para ${ }^{\circ}$ Froude $=2,5$ a 4,5 & & $x$ & $x$ & $x$ \\
\hline & & Barragens & $x$ & $x$ & $x$ & $x$ \\
\hline & & $\begin{array}{l}\text { Vertedores: Queda, Calha e Degrau } \\
\text { "Cacimbo" }\end{array}$ & & $\mathrm{x}$ & $\mathrm{x}$ & $x$ \\
\hline & & Bacia de acumulação & & & $x$ & $x$ \\
\hline & & Bacia dissipadoras & & $\mathrm{x}$ & $x$ & $x$ \\
\hline & & Proteção de taludes & $x$ & $x$ & $x$ & $x$ \\
\hline & & Aterramento com obras hidráulicas & & $\mathrm{x}$ & $x$ & $x$ \\
\hline & & Obras de Pavimentação & $x$ & $x$ & $x$ & $x$ \\
\hline & & Drenos & & $\mathrm{x}$ & $x$ & $x$ \\
\hline \multirow{5}{*}{\multicolumn{2}{|c|}{ 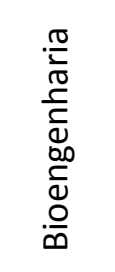 }} & Gabião Vegetado & $x$ & $x$ & $x$ & $x$ \\
\hline & & Geogrelha vegetada & $x$ & $x$ & $x$ & $x$ \\
\hline & & Mantas de gramíneas & $x$ & $\mathrm{x}$ & $x$ & $x$ \\
\hline & & Sistemas de celas de confinamento & $x$ & $x$ & $x$ & $x$ \\
\hline & & Tapete Biodegradável & $x$ & $x$ & $x$ & \\
\hline
\end{tabular}

Dado o grande número de técnicas de controle de erosão apresentadas nesse trabalho, serão descritas, de forma mais detalhada, apenas as medidas relacionadas às áreas de estudo, seja por terem sido empregadas, seja por apresentarem maior adequabilidade aos cenários de degradação analisados. 


\subsubsection{Medidas de recuperação de erosão}

\subsubsection{Revegetação}

No que diz respeito ao controle da erosão a revegetação é considerada como a técnica mais importante, sendo necessária para replantar florestas em áreas desmatadas, onde o risco de falha no restabelecimento vegetal é alto; e para cobrir áreas afetadas pela agricultura, buscando minimizar o dano durante o desflorestamento, estabelecendo a revegetação rapidamente, antes que ocorra deterioração das condições do solo (MORGAN, 1995). A revegetação tem sido intensamente utilizada no mundo desde a metade do século 20 , tanto em ecossistemas naturais, quanto em áreas degradadas, com o objetivo de proteger o solo da erosão pluvial, prevenir inundações, melhorar a estrutura vegetal e combater a desertificação (CHIRINO et al., 2006; ROMERO-DÍAZ; BELMONTE-SERRATO e RUIZ-SINOGA, 2010).

De acordo com Lal (1990) a cobertura florestal, tanto a plantada quanto a natural, fornece maior proteção ao solo contra a erosão, em comparação com culturas anuais ou sazonais, dado que a superfície do solo é continuamente coberta pela copa das árvores e pela serapilheira; e também por não ocorrer distúrbio no solo, como ocorre para o cultivo. O autor ainda aponta para o papel representado pelo sistema radicular das árvores, que forma uma rede, retendo o solo, fornecendo-o uma resistência adicional às forças de cisalhamento do escoamento superficial e do impacto da gota no solo.

Morgan e Rickson (1995) apontam ainda para a ação da cobertura vegetal no processo de infiltração da água no solo. Os autores afirmam que as taxas de infiltração são maiores no solo coberto do que no solo nu, dada a ação do sistema radicular e da fauna associada, que aumentam a porosidade, favorecendo a infiltração. Eles apontam também o fenômeno de evapotranspiração, como um benefício da cobertura vegetal em relação ao controle da erosão, dado que esse fenômeno contribui para a retirada do excesso de água do solo, o que retarda a formação do escoamento superficial.

Além das características apontadas pelos autores anteriores, Ayres (1936) cita as vantagens de realizar a revegetação com espécies florestais. Para o autor as árvores permitem o crescimento de outros tipos vegetais como ervas, gramíneas, arbustos e cipós no seu entorno, contribuindo para que a cobertura do solo seja mais efetiva na retenção da água, liberando-a gradualmente. Outras vantagens relacionadas ao uso de árvores consistem no fato de que estas podem ser facilmente estabelecidas, com baixo custo e de forma mais eficiente em comparação 
a outros tipos de cobertura vegetal. Por outro lado, há uma desvantagem associada à capacidade limitada desse tipo de vegetação em conter toda a água da chuva, dado que a cobertura fornecida pela folhagem e o sistema radicular são impotentes em prevenir a acumulação do escoamento superficial.

A aplicação dessa metodologia em projetos de prevenção, controle, mitigação ou recuperação da erosão deve ser devidamente programada. Morgan (1995) afirma que ao se desenvolver um plano de revegetação para uma determinada área, vários aspectos devem ser considerados. Segundo o autor, ensaios do solo devem ser realizados para estabelecer o $\mathrm{pH}$, os níveis de nutrientes, o teor de umidade, os níveis de salinidade e a presença de íons tóxicos, dado que esses fatores influenciam a gama de espécies que irão se desenvolver. As condições climáticas também devem ser estudadas, incluindo a frequência de secas e chuvas. A influência topográfica no clima local também é importante; por exemplo, diferenças de temperatura e umidade podem ser observadas entre encostas com insolação diferentes.

No que diz respeito às espécies de plantas a serem utilizadas, estas devem ser selecionadas com base em propriedades como rápido crescimento, resistência a doenças e pragas, habilidade de competir com espécies menos desejáveis e adaptabilidade às condições locais de solo e clima. Sempre que possível, as espécies nativas devem ser escolhidas. Pode-se ter uma boa indicação de quais espécies terão mais chances de sobreviver e se desenvolver através um estudo de áreas vizinhas. Porém o uso de espécies introduzidas ou exóticas não deve ser descartado, especialmente em locais onde tanto o ambiente local quanto as áreas adjacentes tenham sido degradados, e também em casos onde as espécies locais sejam limitadas. Deve-se ainda assegurar que o plano de revegetação permita a sucessão natural, de modo que as espécies pioneiras se estabeleçam, promovendo uma cobertura imediata, melhorando as qualidades do solo, e então permitindo que as espécies nativas as substituam. Na prática, geralmente, é necessária uma mistura de espécies vegetais, dado que é impossível prever o sucesso de uma única espécie em certos ambientes, onde não ocorra a devida manutenção. $A$ mistura de espécies deve incluir gramíneas, ervas e espécies lenhosas como arbustos e árvores (MORGAN, 1995).

A utilização da revegetação no controle da erosão pode variar para cada área, de acordo com os fatores citados anteriormente por Morgan (1995). Dessa forma, é compreensível que as abordagens dessa técnica sejam distintas em áreas tropicais e temperadas. Em seus estudos, desenvolvidos nos Estados Unidos, Ayres (1936) aponta que as árvores são o tipo mais adequado de vegetação para ser empregada em áreas degradadas por erosão. Para o autor, em casos de 
feições profundas, a revegetação com árvores deve ser associada a diques no interior da feição; porém, para controlar feições menos profundas apenas a revegetação é suficiente.

Em seu trabalho, Ayres (1936) descreve características técnicas relacionadas à implantação da revegetação em áreas degradadas por voçorocas. Segundo ele, em muitos casos, as árvores devem ser plantadas nas bordas das paredes e da cabeceira, estendendo-se cerca de 15 metros das mesmas, podendo este valor variar de acordo com a declividade e com as características do solo. O espaçamento entre as árvores, no interior das feições (englobando tanto as paredes quanto o fundo), deve ser em torno de 1 metro; enquanto que nas áreas de entorno não deve ser maior que 1,80 metros. Quanto à configuração, as árvores devem ter suas raízes fixadas de forma profunda, sendo o solo compactado ao redor das mesmas, com as mãos ou com alguma ferramenta. O autor sugere ainda espécies vegetais mais adequadas, caracterizadas por crescerem rápido, por apresentarem um sistema radicular espesso e amplo e por aumentar a fertilidade do solo onde se desenvolvem, o que favorece o surgimento de outras espécies vegetais. Morgan e Rickson (1995), por sua vez, descrevem a melhor configuração para a aplicação de coberturas vegetais para prevenção da erosão em encostas e taludes. Em seu trabalho os autores indicam diferentes espécies de gramíneas, adequadas para a proteção de encostas contra a erosão no Reino Unido. Da mesma forma, listam uma série de espécies vegetais empregadas com sucesso no controle da erosão superficial em áreas de construção e de minas desativadas nos EUA, classificadas quanto à adequabilidade ao clima e ao tipo de solo.

No Brasil, pode-se citar o trabalho realizado por Pereira (2008), que relaciona a revegetação com o controle da erosão. De acordo com o autor, se a vegetação for implantada de forma inadequada, áreas degradadas podem não ser controladas ou recuperadas, e ainda, áreas estáveis podem ser erodidas. São muitas as espécies vegetais que podem ser utilizadas para estabilizar taludes, revegetar áreas impactadas, controlar a erosão e proteger áreas marginais; e estas devem ser escolhidas com base nas características ambientais e climáticas. $O$ autor reúne em seu trabalho uma listagem de várias espécies de leguminosas e gramíneas, indicadas para o uso na recuperação de áreas degradadas e para o controle da erosão. Cada espécie é classificada de acordo com a sua adequabilidade a determinadas condições de altitude, precipitação, temperatura, fertilidade do solo, e tolerância a situações de seca, acidez, geada, fogo, alagamento e pragas. E ainda são caracterizadas quanto aos tipos de raízes, propagação, formação e porte. É apresentada também uma listagem de espécies arbóreas acompanhadas de suas características e usos específicos para a recuperação ambiental. 
Dada a importância da revegetação, ou reflorestamento, no controle da erosão, são comuns os casos de recuperação que envolvam essa técnica em conjunto de outras, geralmente mecânicas ou estruturais. Em seu trabalho, Zhang, Yang e Zepp (2004) apresentam um caso de recuperação de uma área erodida onde a revegetação foi aplicada em conjunto com outras técnicas. O local do estudo consiste em uma área experimental, degradada por voçorocas. $\mathrm{O}$ processo de recuperação incluiu medidas como a construção de diques de blocos de rocha no interior das feições; plantação em contorno de espécies pioneiras de árvores e arbustos de leguminosas locais; e aplicação de fertilizantes. O processo de revegetação se deu com a utilização de quatro espécies vegetais, e cobertura da superfície do solo com restos de palha, no interior das voçorocas. Nas paredes, por sua vez, foi empregada uma quinta espécie, semeada em sulcos, nas declividades inferiores a $30^{\circ}$, e em cavas, nas declividades superiores a $30^{\circ}$. Em ambos os casos foram empregados fertilizantes. Paralelamente foram adotadas as técnicascom o objetivo principal de melhorar as taxas de umidade do solo, reduzindo o escoamento superficial e de suavizar a topografia. O desempenho geral do plano de recuperação foi satisfatório. Os autores afirmaram que após 3 anos da implantação a cobertura vegetal passou a abranger $95 \%$ da área, sendo que espécies de diferentes estágios de sucessão surgiram, e que nenhuma planta morreu, mesmo nas épocas de seca. Passados 12 anos a fertilidade do solo aumentou, assim como as taxas de matéria orgânica, nitrogênio e $\mathrm{pH}$; garantindo o crescimento vegetal a longo prazo.

Outro exemplo bem sucedido de recuperação de uma área degradada por erosão, a partir de técnicas de revegetação consiste no projeto de reflorestamento do talude da estrada de Itaipu, no Município de Niterói, Rio de Janeiro, apresentado por Barroso et al. (2001). Segundo os autores, o talude sofria as consequências da movimentação do solo e da retirada da cobertura vegetal, sobretudo em áreas mais inclinadas, causando sérios prejuízos nas épocas de chuva. O projeto de recuperação envolveu, além da revegetação, medidas estruturais na forma de obras de drenagem (canaletas), dispostas no topo e no meio do talude, e de uma escada hidráulica e tubulação, cujo objetivo era disciplinar as águas do escoamento pluvial. A revegetação por sua vez, se deu após análise do solo que verificou as condições de degradação do mesmo, indicando a necessidade de adubação. Baseado no perfil longitudinal do talude foi determinado o espaçamento entre as plantas, de cerca de 1 metro, e então foram plantadas dez mil mudas, abrangendo uma área total de 1,5 hectare. Para esse projeto foram escolhidas seis espécies de leguminosas florestais, caracterizadas por apresentar rápido crescimento e boa adaptação ao ambiente da região, dado que não eram espécies nativas. $\mathrm{O}$ acompanhamento da 
evolução do plano indicou um bom desempenho, sobretudo no desenvolvimento de duas espécies, que chegaram a alcançar de 12 a 15 metros de altura passados sete anos. Foi detectada ainda no local a ocorrência da regeneração natural de várias espécies nativas, dado que a deposição de folhas e o crescimento das raízes estabilizam o solo, aumentam a atividade biológica e propiciando o estabelecimento de espécies mais exigentes em termos de nutrientes.

\subsubsection{Técnicas conservacionistas de pastagem}

As áreas de pastagem compreendem pastos melhorados, onde as espécies de gramíneas e de leguminosas, adaptadas às condições do solo e do clima locais, são plantadas e manejadas através de aplicações constantes de calcário, fertilizantes e matéria orgânica. Esse uso do solo pode também envolver espécies nativas de gramíneas e arbustos. Espera-se que a espécie de gramínea adotada confira uma cobertura densa e rente à superfície do solo, sendo assim uma boa opção para sua proteção contra a erosão (MORGAN, 1995). Faixas de pastagens permanentes podem ser empregadas entre áreas de cultivo e áreas florestais, constituindo assim uma medida econômica e efetiva de controle da erosão (AYRES, 1936).

Os problemas relacionados à utilização dessa medida no controle da erosão só se iniciam quando a cobertura é removida devido ao superpastoreio, embora esta possa ser acelerada pelas secas e pelas queimadas excessivas. A eficiência dessa metodologia é função da adoção de práticas de manejo, principalmente aquelas voltadas a manter as taxas de lotação (quantidade de animais por área) adequadas, o que muitas vezes é impossível, dada a questão cultural associada ao tamanho do rebanho (LAL, 1990 e MORGAN, 1995).

Bertoni e Lombardi Neto (1993) chamam a atenção para o fato de que, muitas vezes, o peso do gado pode ser muito grande, provocando o raleamento e a redução das pastagens. A solução desse problema aponta mais uma vez para a importância das práticas de manejo. Os autores indicam o rodízio de pastagens como solução, de modo que a área total seja dividida em um determinado número de parcelas, e que o gado seja passado de uma para a outra, dentro de uma determinada sequência, conferindo tempo para a recuperação da cobertura vegetal. Outra prática importante, que visa tanto a capacidade de suporte ao gado, quanto a proteção do solo contra a erosão, consiste no ressemeio periódico, empregando tanto a reforma da pastagem quanto a plantação de mudas de espécies de capim ou leguminosas mais indicadas.

Apesar da sua importância, não existem indicações precisas sobre práticas de manejo das pastagens, dado que as condições naturais e a adequabilidade das espécies variam com o local. 
Porém um guia geral de práticas foi proposto por Bertoni e Lombardi Neto (1993), através do qual os autores indicam que:

- O pasto deve ser mantido livre de ervas daninhas, e deve apresentar misturas de leguminosas e gramíneas;

- A fertilização química do solo deve ser aplicada sempre que for necessário. Assim como, a correção da acidez do solo, através da aplicação de calcário, também é necessária quando os níveis estiverem muito altos, o que pode interferir no desenvolvimento das leguminosas;

- Os pastos recém-estabelecidos não devem ser pastoreados até que o sistema radicular tenha se desenvolvido de forma adequada;

- As árvores de sombra, para abrigo do gado, devem ser plantadas na parte alta do terreno, longe de córregos e riachos;

- Deve-se evitar o superpastoreio;

- A adoção do pastoreio misto (várias espécies de animais) assegura uma melhor utilização da pastagem, e deve ser empregado quando possível;

- E finalmente, a adoção de sulcos e camalhões em contorno é uma prática aconselhável para solos argilosos, regiões de pouca chuva e para pastagens em formação.

Em seu trabalho Lal (1990) apresenta uma série de estudos que verificaram que as taxas de erosão em pastos bem manejados são menores do que em áreas de cultivo intenso; e também aponta resultados que indicam que a erosão é maior em pastagens degradadas, apontando para a importância da manutenção contínua dessa técnica.

Sistemas de pastagens tradicionais, bem adaptados às condições locais de clima, solo e vegetação, utilizam muito a técnica de rotação de pastagens, evitando situações de degradação do solo. Um exemplo descrito por Barrow (1989) cita uma comunidade do Quênia, que apresenta um sistema flexível, controlado cuidadosamente pelos anciãos. Por este, o gado é manejado nas planícies imediatamente após a época de cheia, buscando aproveitar ao máximo o bom desenvolvimento das gramíneas, sendo então encaminhado para áreas de montanhas, ligeiramente mais úmidas, nas estações secas. No final dessa estação a criação é estabelecida em uma propriedade rural, às margens de uma floresta que fornece forragem. Além disso, sorgo é plantado durante as chuvas, sendo manejado pelas mulheres, para servir de suplemento à dieta do gado. E ainda, nas estações secas, as pastagens montanhosas são manejadas comunitariamente, para serem usadas apenas em períodos de extrema seca. 
Práticas de manejo relacionadas à conservação da pastagem podem ser bastante eficientes. Na Figura 7, estão indicadas duas áreas de pastagem pertencentes ao município de Santa Rita do Araguaia - GO. Na Área 1 foram plantadas árvores nos cordões de nível, intensificando a ação preventiva dessa estrutura. Pode-se observar que não há a presença de feições erosivas, ou trechos de solo exposto nessa porção, em comparação com a Área 2 que apresenta os mesmos materiais geológicos, e onde não há a presença de medidas de conservação da pastagem. Nesse trecho, pode-se observar grandes falhas na continuidade do pasto, porções de solo exposto, e até mesmo feições erosivas.

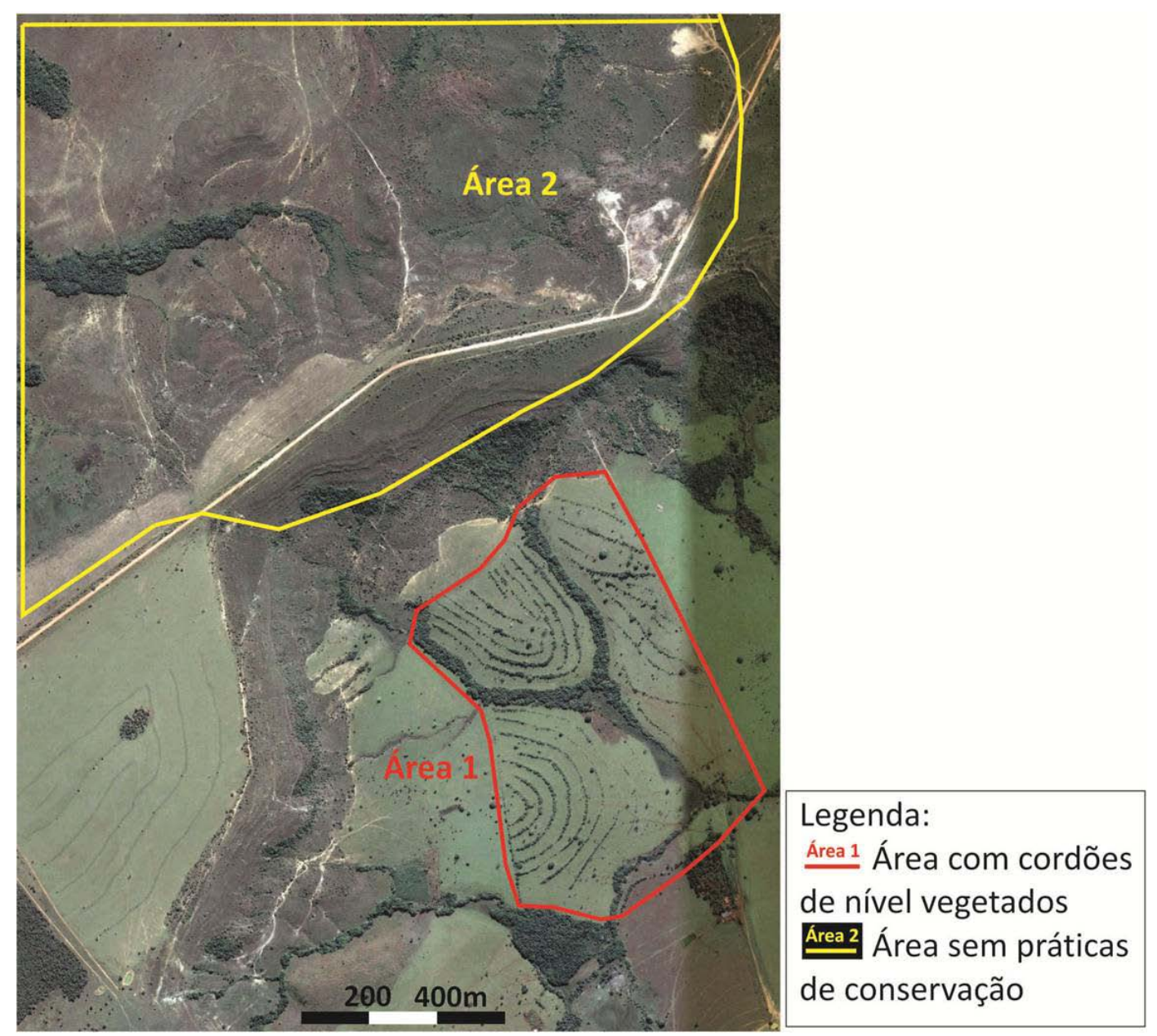

Figura 7: Pastagens com e sem práticas de manejo, com diferentes condições de conservação em Santa Rita do Araguaia, GO.

\subsubsection{Barreira de Galhos (Brush Barrier)}

Essa medida consiste no empilhamento ordenado de galhos e outras estruturas vegetais, na base de encostas e taludes. É uma técnica temporária, que consiste em uma barreira de 
sedimentos, construída em áreas que apresentam algum tipo de degradação, utilizando-se materiais disponíveis no próprio local, resultantes da remoção da cobertura vegetal (VIRGINIA DEPARTMENT OF CONSERVATION \& RECREATION, 1992 E ALASKA DEPARTMENT OF TANSPORTATION AND PUBLIC FACILITIES, 2001). O objetivo principal dessa medida é interceptar o escoamento acelerado, retendo o sedimento e impedindo-o de deixar a área de onde foi destacado. Secundariamente, apresenta a função de diminuir a velocidade do escoamento, e assim sua ação erosiva (VIRGINIA DEPARTMENT OF CONSERVATION \& RECREATION, 1992).

A barreira de galhos, apesar do nome, pode ser feita também a partir de ervas, cipós, raízes, solo, bloco de rochas e outros materiais. Estes são todos empilhados e posicionados no meio ou na base de encostas ou taludes suscetíveis à erosão laminar e linear (ALASKA DEPARTMENT OF TANSPORTATION AND PUBLIC FACILITIES, 2001).

Algumas considerações devem ser feitas para a construção dessa técnica. Além da disponibilidade de material no local, recomenda-se que a área de captação onde a barreira de galhos será aplicada não ultrapasse $2500 \mathrm{~m}^{2}$, para uma barreira de até 30 metros de comprimento; que o comprimento máximo da encosta a montante da medida não ultrapasse 30 metros; e que a inclinação máxima dessa encosta seja igual a $26,56^{\circ}$ ou $50 \%$ (VIRGINIA DEPARTMENT OF CONSERVATION \& RECREATION, 1992). No que se refere às dimensões da barreira de galhos, determina-se que a altura varie entre 0,9 a 1,5 metros, e que a largura da base compreenda entre 1,5 e 4,6 metros (ALASKA DEPARTMENT OF TANSPORTATION AND PUBLIC FACILITIES, 2001). A Figura 8 representa esquematicamente essa técnica.

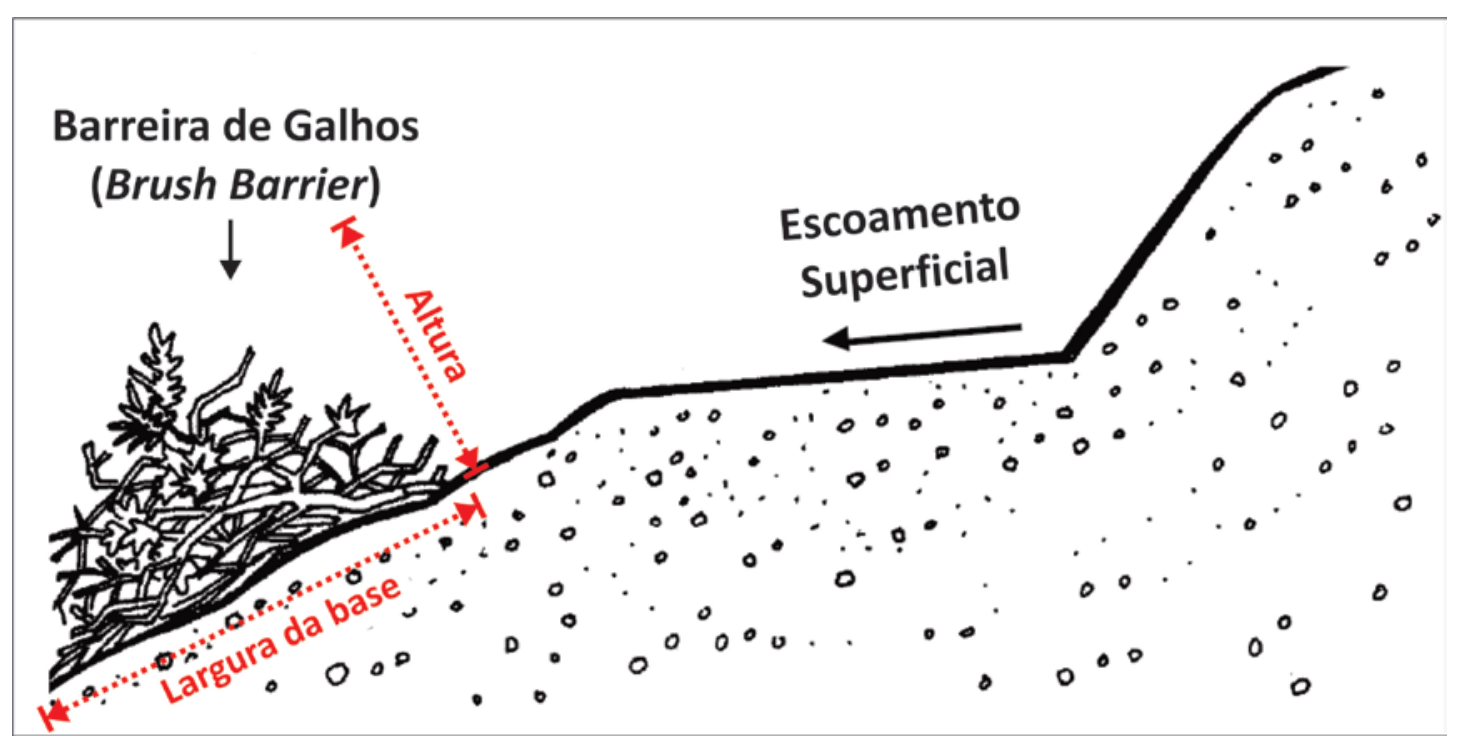

Figura 8: Seção transversal da Barreira de Galhos (Brush Barrier) (modificado de KELLER e SHERAR, 2003). 
Alguns cuidados são necessários durante a aplicação dessa medida: não se devem usar materiais que possuam diâmetro maior que $15 \mathrm{~cm}$, pois estes criam vazios nos montes, por onde o escoamento carregado de sedimentos pode passar facilmente. Deve-se evitar também que os materiais fiquem frouxos e criem vazios. E finalmente, deve-se ficar atento à acumulação dos sedimentos, dado que esta pode levar a barreira a perder sua capacidade de filtração. É importante considerar que as barreiras de galhos não atuam como barragens, dado que se estas fossem impermeáveis, a água do escoamento superficial se acumularia e um tratamento adicional seria necessário (ALASKA DEPARTMENT OF TANSPORTATION AND PUBLIC FACILITIES, 2001).

Dado o caráter vegetativo dessa medida, é necessário que ocorra manutenção da mesma. Tanto o Virginia Departament of Conservation \& Recreation (1992) quanto o Alaska Department of Transportation and Public Facilities (2001) recomendam inspeções semanais e/ou depois de grandes eventos de chuva, sobretudo para avaliar a acumulação de sedimento; sendo necessária a remoção do mesmo quando alcançarem altura igual a um terço a metade da altura da barreira.

Em alguns casos uma cobertura geotextil pode ser empregada, seguindo algumas especificações, favorecendo tanto a estabilização da barreira, quanto aumentando sua capacidade de filtração; enquadrando-se assim no grupo de técnicas de bioengenharia.

Rotta e Zuquette (2012) apresentam uma aplicação dessa medida em uma área afetada pela erosão no município de São Pedro - SP. A área compreende duas bacias hidrográficas de segunda ordem, que apresentam grandes voçorocas, bastante antigas, sobretudo próximas aos canais de drenagem, originadas pelo processo de uso e ocupação. A cobertura vegetal atual compreende um reflorestamento de eucaliptos com finalidade comercial, de modo que frequentemente as árvores são cortadas e replantadas. A preocupação com o processo erosivo se concentra na manutenção das encostas, o que motivou os proprietários a implantarem as barreiras de galhos (brush barrier) entre as faixas de eucalipto. As barreiras são constituídas de ramos secos e resíduos de galhos e casca de árvores, encontrados no próprio local, e apresentam como objetivo principal diminuir a velocidade do escoamento superficial, intensificar as taxas de infiltração, e filtrar o sedimento do escoamento. O sucesso dessa medida é verificado pela ausência de feições erosivas de qualquer dimensão nas encostas, e também pela manutenção das próprias barreiras. 


\subsubsection{Terraceamento}

Ayres (1936) afirma que os terraços consistem em séries de grandes ondulações em intervalos dispostos em uma encosta, e usualmente são construídos em leves degraus longitudinais que diminuem a velocidade do escoamento em excesso. Na prática, cada terraço funciona como um fosso raso que intercepta o escoamento superficial em sua área de captação e o conduz em menor velocidade, antes que a água tenha chance de alcançar volumes e velocidades erosivas.

Esse método consiste em um tipo especial de sulco ou canal, visando, além de interceptar a água da enxurrada, conduzir o excesso pelo canal. De acordo com Guerra (1998), os terraços devem ser construídos perpendicularmente à inclinação das encostas, para interromper o escoamento superficial, e também para reduzir o comprimento de rampas. É preciso definir o espaçamento e comprimento dos terraços, os locais de saída da água, e o próprio esquema geral dos terraços, numa encosta. Estes podem ser construídos com três objetivos básicos: interceptar o fluxo de água superficial e canalizá-lo perpendicularmente à inclinação das encostas; aumentar o armazenamento de água na encosta ou construir degraus, com mais de $30 \mathrm{~cm}$, que precisam ser cultivados.

Esquematicamente, o terraço constitui-se de um canal e um camalhão, sendo o canal a parte do terreno onde foi realizado o corte, e o camalhão ao aterro, construído a partir do solo removido do canal, conforme pode ser observado na Figura 9 (EMBRAPA, 2004).

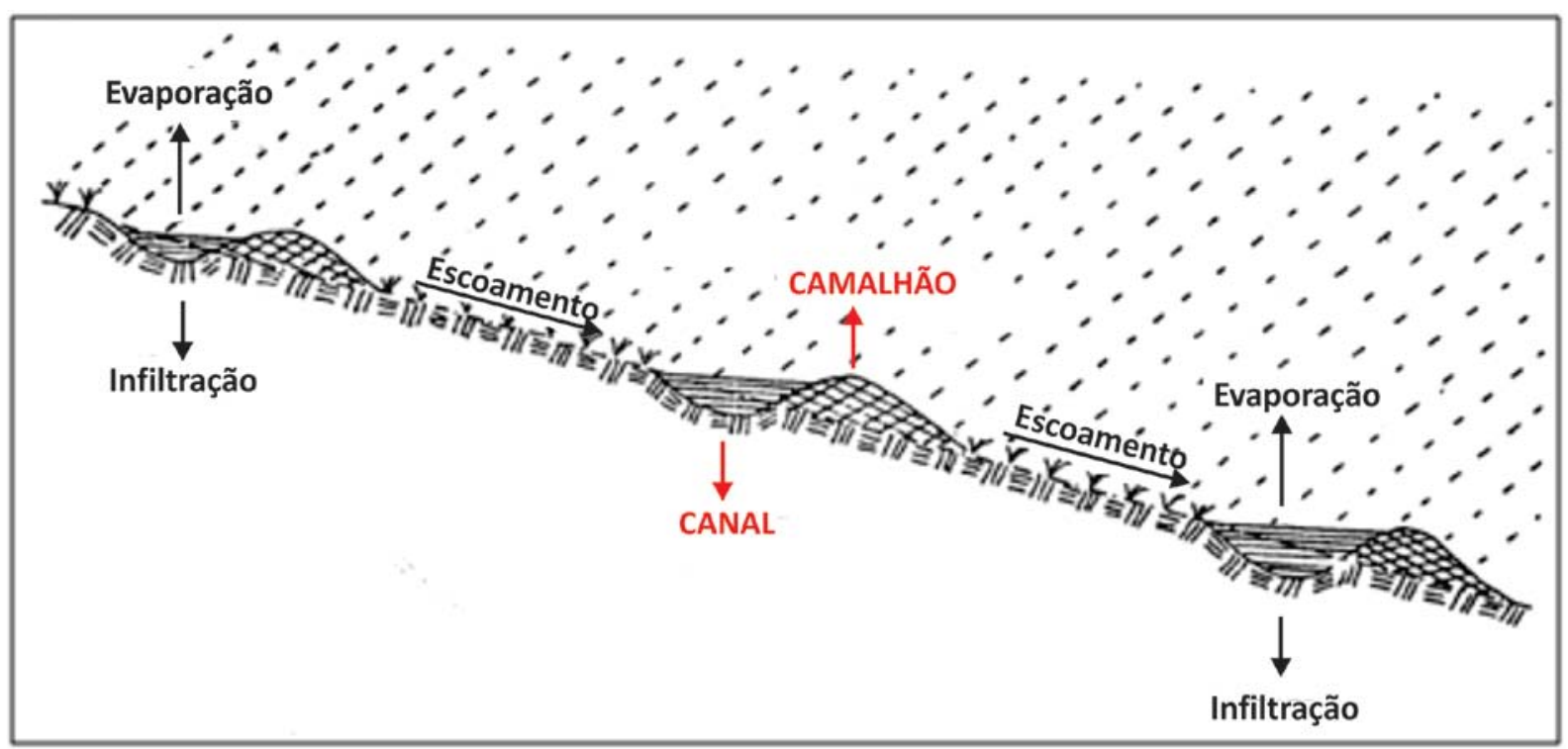

Figura 9: Visão esquemática do terraceamento indicando o seccionamento da rampa com a construção de terraços (BERTOLINI, D. et. al., 1989 apud EMBRAPA, 2004). 
Segundo Cadenas de Llano (1998), os terraços podem ser classificados quanto ao seu traçado, à sua função, ao seu perfil e quando ao seu modo de construção.

Quanto à função, tanto Cadenas de Llano (1998) quanto a Embrapa (2004) apontam a existência de dois tipos básicos de terraços: o de desnível ou drenagem e o de nível ou infiltração. O terraço de infiltração, segundo os autores, tem o objetivo de reter, armazenar e infiltrar o excesso de água proveniente do escoamento superficial, controlando assim a erosão. Já o terraço de drenagem deve interceptar o escoamento superficial e escoar disciplinadamente o excesso de água para canais escoadouros. A Embrapa (2004) indica que a escolha entre esses dois tipos de canais deve se basear nas propriedades físicas do solo, tais como textura, estrutura, profundidade efetiva e permeabilidade da camada superficial e subsuperficial, que definem a permeabilidade da água em seu perfil.

De acordo com o tipo de construção, Bertoni e Lombardi Neto (1993), apresentam os tipos Mangum, Nichols, que de acordo com sua dimensão podem ser separados em terraços de base larga e de base estreita. O tipo Mangum (Figura 10) é construído pelos dois lados do terreno, dando assim um terraço de camalhão mais alto; é o tipo adaptado para a conservação da água. A Embrapa (2004) afirma ainda que esse tipo de terraço apresenta canais mais largos e rasos. É ainda mais indicado para terrenos de menor declividade.

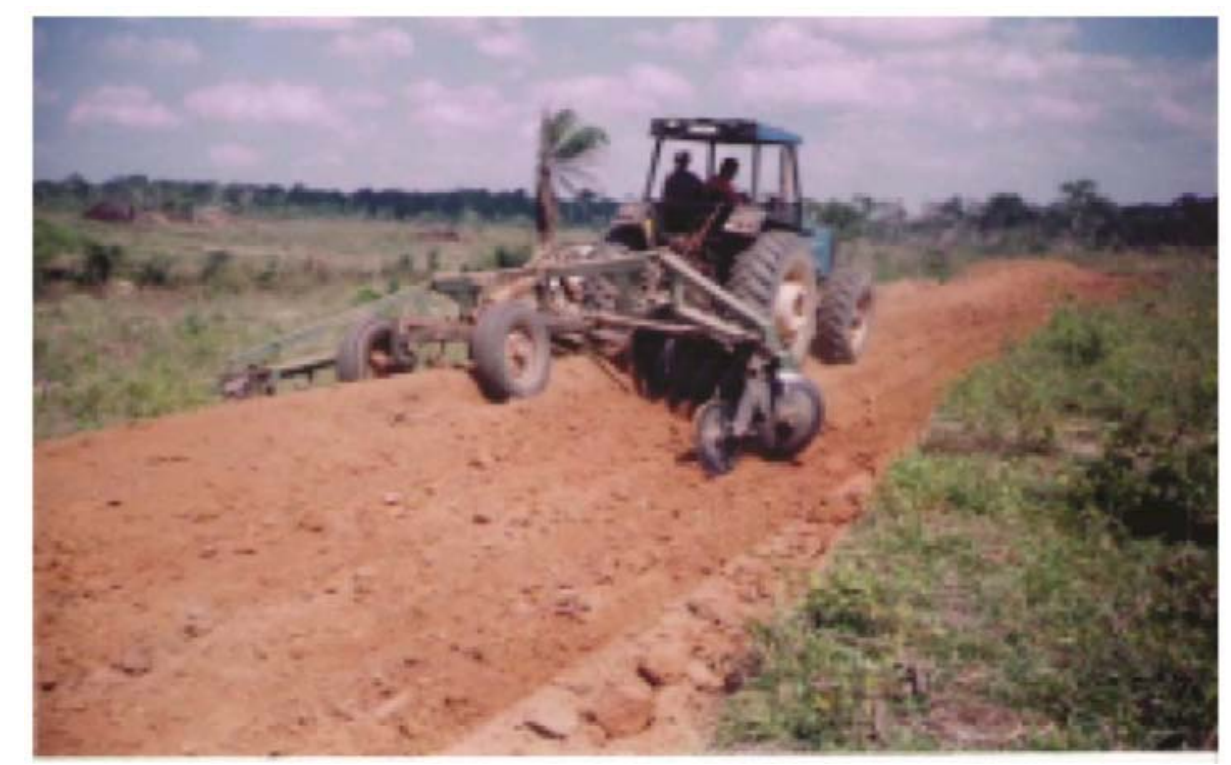

Figura 10: Terraço tipo Mangum, de base média, construído com terraceador, Acrelância - Acre (EMBRAPA, 2004).

O tipo Nichols (Figura 11) é construído cortando-se a terra e movimentando-a apenas do lado de cima do terreno, gerando um canal. A deposição do material retirado dá origem ao 
camalhão. Esse tipo de terraço se adéqua tanto a áreas de maior quanto de menor declividade, e para sua execução deve ser utilizado um arado de disco reversível (EMBRAPA, 2004).

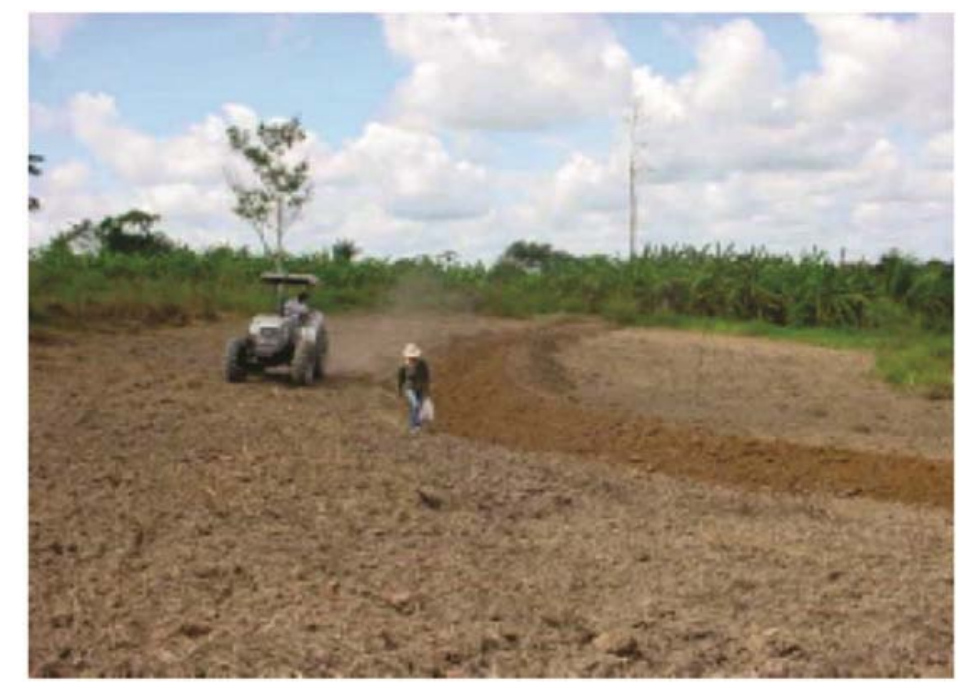

Figura 11: Terraço tipo Nichols, de base estreita, construído com arado reversível, em Bujari - Acre (EMBRAPA, 2004).

O tipo de base larga é bastante largo, raso, de suave inclinação. É usado freqüentemente em áreas de cultivo, uma vez que permitem o uso de máquinas agrícolas. Indicado para terrenos pouco inclinados de $0,5 \%$ a $12 \%$ de declividade, mas caso seja um solo de boa permeabilidade, a declividade pode atingir $20 \%$. Porém, em terrenos com topografia irregular, é bastante difícil sua construção. Enquanto que o de base estreita consiste em uma combinação de valetas e leiras (montes de terra em nível) de pequenas dimensões. É chamado de "cordões-em-contorno", sendo normalmente indicado para pequenas propriedades, com baixa intensidade de mecanização agrícola e para áreas com até $18 \%$ de declividade (BERTONI E LOMBARDI NETO, 1993 e EMBRAPA 2004).

Por fim, quanto à forma, os terraços se dividem em Patamar, circular e comum. O tipo conhecido como Patamar consiste em plataformas construídas em terrenos de grande inclinação (declividades superiores a 18\%), formando uma espécie de degraus (BERTONI E LOMBARDI NETO, 1993). São construídos perpendicularmente à linha de maior declive, e constituem uma plataforma onde são plantadas as culturas, e um talude que deve ser estabilizado com revestimento de grama ou outro tipo de vegetação (EMBRAPA, 2004). O tipo Individual consiste em um pequeno patamar circular ou oval construído ao redor de cada planta de culturas perenes já formadas; sendo também usado em terreno de grande inclinação (BERTONI E LOMBARDI NETO, 1993). 
E ainda, o tipo comum é definido pela Embrapa (2004) como uma construção de terra, em nível ou em desnível composta por um canal e um camalhão, utilizado em terrenos de até $18 \%$ de declividade. O tipo comum embutido é construído de tal forma que seu canal tem formato triangular, e o talude que o separa do camalhão é praticamente vertical. E o tipo comum "murundum" possui um camalhão alto, de cerca de 2 metros, e um canal de sessão triangular. Não é favorável ao cultivo, sendo aconselhável apenas em casos em que se deseja reter grandes quantidades de água.

Em termos construtivos, Ayres (1936) afirma que o primeiro terraço, de qualquer tipo, deve ser localizado próximo o suficiente do topo da encosta para prevenir que a erosão se inicie. Os demais terraços devem ser espaçados buscando servir ao mesmo propósito. Essa estrutura não deve ser construída seguindo precisamente o contorno do terreno, sendo necessário um ligeiro desnível longitudinal, que tem como função coletar a água, e conduzi-la ao longo do terraço, até uma tomada d'água (canal) localizada nas bordas do terreno. O tamanho e a inclinação do canal devem ser ajustados para carregar o máximo escoamento, evitando, porém que sua velocidade seja muito intensa, e que haja transbordamento. Nesse contexto o autor afirma que o escoamento máximo, ou crítico, pode ser obtido pela Equação 1.

$$
Q=C \times I \times A
$$

Onde:

$Q=$ escoamento crítico em $\left(\mathrm{m}^{3} \mathrm{~s}^{-1}\right)$;

$C=$ coeficiente de escoamento, que representa a relação entre a taxa de escoamento e a taxa de precipitação;

$\mathrm{I}=$ intensidade da precipitação $\left(\mathrm{m} / \mathrm{s} \cdot \mathrm{m}^{2}\right)$;

$A=$ função do comprimento do terraço e do espaçamento entre estes $\left(\mathrm{m}^{2}\right)$.

Ayres (1936) indica também que o espaçamento entre os terraços deve ser tal que sua construção seja econômica, com pouca interferência no uso do solo e que demande pouca manutenção. Esse valor deve ser expresso em metros, podendo ser obtido por uma regra empírica, que consiste em adicionar $3 \%$ à declividade do terreno e dividir por dois. Essa regra pode ser utilizada para inclinações de até $6 \%$, sendo que para valores superiores é indicado que os espaçamentos sejam muito maiores. Em seu trabalho, o autor apresenta ainda uma tabela 
(Tabela 2) com valores médios de espaçamento entre terraços, relacionados a declividades médias do terreno, obtidos a partir de experiências locais nos Estados Unidos.

Tabela 2: Valores de espaçamento entre terraços obtidos a partir de experiências locais nos Estados Unidos (AYRES, 1936).

\begin{tabular}{|c|c|c|c|}
\hline \multirow{2}{*}{$\begin{array}{c}\text { Declividade } \\
(\mathbf{m} / \mathbf{1 0 0} \mathbf{m})\end{array}$} & \multicolumn{2}{|c|}{ Desnível vertical entre terraços (m) } & Distância entre \\
\cline { 2 - 3 } & Estados do norte & Estados ao Sul & terraços (m) \\
\hline 2 & 0,84 & 0,76 & 41,91 \\
\hline 4 & 1,04 & 0,91 & 25,91 \\
\hline 6 & 1,22 & 1,07 & 20,32 \\
\hline 8 & 1,45 & 1,22 & 18,10 \\
\hline 10 & 1,68 & 1,37 & 16,76 \\
\hline 12 & 1,92 & 1,52 & 16,00 \\
\hline 14 & 2,16 & 1,68 & 15,46 \\
\hline
\end{tabular}

Beasley (1972) indica que os principais fatores que afetam o espaçamento entre terraços são a inclinação do terreno, o tipo de solo, a intensidade de chuva, o tipo de cultivo e o tipo de maquinário a ser utilizado no manejo do solo. Ele afirma que, em muitos lugares, o espaçamento entre os terraços é determinado por experiência de campo, mas apresenta uma equação que pode ser utilizada em locais que não estejam disponíveis maiores informações. A equação é:

$$
V I=X S+Y
$$

Onde:

$\mathrm{VI}=$ intervalo vertical entre os terraços $(\mathrm{m})$;

$X$ = variável dependente da localização geográfica;

$\mathrm{S}=$ declividade média do terreno (\%);

$\mathrm{Y}=$ variável com valores entre 1 e 4 , que dependem da erodibilidade do solo, dos sistemas de cultivo e do sistema de manejo, O valor mais baixo é aplicado para solos muito erodíveis, com métodos convencionais de cultivo, onde poucos resíduos são deixados na superfície. E o valor mais alto é aplicado para solos resistentes à erosão, onde os métodos de cultivo deixam grandes quantidades de resíduo na superfície.

Vale ressaltar que o intervalo vertical, ou diferença de elevação entre os terraços, obtido por essa equação, é utilizado para determinar o "layout" de terraços paralelos, pois em 
topografias irregulares a distância superficial entre os terraços varia de acordo com a inclinação do terreno (BEASLEY, 1972).

Dando continuidade, Beasley (1972) afirma que em terraços paralelos o intervalo horizontal pode ser obtido a partir do valor do intervalo vertical, sendo então empregado para se obter o espaçamento entre os terraços. O intervalo horizontal pode ser calculado a partir da equação 3.

$$
H I=\frac{V I}{S} \times 100
$$

Onde:

$\mathrm{HI}=$ intervalo horizontal entre os terraços $(\mathrm{m})$;

$\mathrm{VI}=$ intervalo vertical entre os terraços $(\mathrm{m})$;

S: declividade média do terreno (\%).

Para muitos valores de inclinação do terreno que os terraços são construídos, praticamente não há diferença entre a distância horizontal e a distância entre os terraços, de modo que a segunda pode ser obtida a partir da primeira, por meio de relações geométricas simples, conforme sugere a Figura 12 (BEASLEY, 1972).

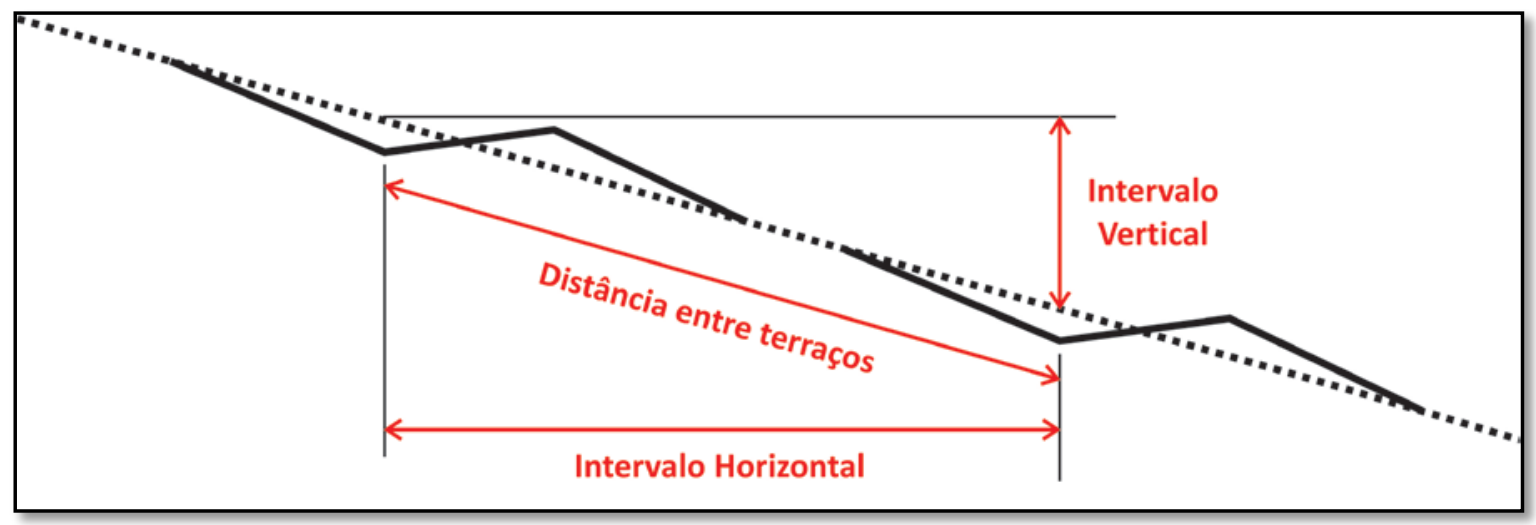

Figura 12: Medidas relacionadas ao espaçamento entre terraços (modificado de BEASLEY, 1972).

Em seu trabalho Bertoni e Lombardi Neto (1993) reuniram uma série de equações que são utilizadas para o cálculo do espaçamento entre os terraços, em diferentes lugares do mundo, tanto para terraços paralelos, quanto para terraços não paralelos. Além disso, os autores apresentam o trabalho desenvolvido por Bertoni (1959) que se baseou em experiências de 10 
anos com solos brasileiros, para propor uma equação (representada a seguir) adaptada aos solos do estado de São Paulo.

$$
E V=0,4518 \times K \times D^{0,58}
$$

Onde:

$\mathrm{EV}=$ espaçamento vertical entre terraços;

$\mathrm{D}=$ declividade do terreno;

$\mathrm{K}=$ constante para cada tipo de solo, cujos valores calculados foram os seguintes: arenoso $=0,835$, argiloso $=0,954$, roxa $=1,212$.

Quanto ao gradiente, os terraços podem ser de vários tipos, sendo que cada um se adapta melhor a condições específicas. Os terraços em nível são usados satisfatoriamente em solos que permitam taxas de infiltração aproximadamente iguais a taxas de escoamento, ou em regiões de chuva esparsa. No último caso, é possível fechar as duas extremidades do terraço e forçar toda água a se infiltrar no solo. Já terraços com inclinação são facilmente demarcados e necessitam menos manutenção para retirada de sedimentos dos canais (AYRES, 1936).

Beasley (1972) indica que é difícil construir terraços com inclinação inferir a 0,1\%, mas sugere valores entre $0,2 \%$ para solos de baixa permeabilidade e $0 \%$ para solos altamente permeáveis. Porém, ele afirma que gradientes muito elevados exigem cuidados, dado que estes podem aumentar a velocidade do escoamento, ocasionando erosão no canal. Existem recomendações para velocidade máxima que pode ser aplicada nos canais, a partir da qual, pode-se obter o gradiente máximo, pela fórmula de Manning, para valores de rugosidade em torno de 0,03 .

Em termos de seções transversais, os terraços devem ser construídos ajustando-se a largura e profundidade dos canais para suportar ou exceder o escoamento crítico. A capacidade coletora do canal pode ser obtida pela fórmula (AYRES, 1936):

$$
Q=a \frac{1,486}{n} R^{\frac{2}{3}} S^{\frac{1}{2}}
$$

Onde:

$\mathrm{Q}=$ Capacidade de vazão $\left(\mathrm{m}^{3} / \mathrm{s}\right)$;

$\mathrm{a}=$ área da seção transversal do canal $\left(\mathrm{m}^{2}\right)$; 
$\mathrm{n}$ = coeficiente cujo valor depende do grau de rugosidade ou irregularidade do canal;

$\mathrm{R}=\mathrm{a} / \mathrm{p}=$ raio hidráulico que consiste no quociente da área da seção transversal do canal, divido pelo perímetro molhado $(p)$;

$\mathrm{S}=$ gradiente $(\mathrm{m} / 100 \mathrm{~m})$.

Pode-se perceber que o formato da seção do canal afeta a vazão através do fator $R$. Um canal largo e raso é melhor que um estreito e profundo, pois facilita a utilização de máquinas agrícolas no local, e tem capacidade de transportar as mesmas quantidades de escoamento, em uma velocidade menor (AYRES, 1936). Os tipos existentes de seção são, principalmente, os de base larga inclinados, de base larga em nível, de encosta íngreme, de canal plano ou de bancadas. As dimensões de cada um são determinadas de acordo com o volume de escoamento que devem suportar, baseando-se nas relações geométricas e na equação de Manning, adequadas a cada caso (BEASLEY, 1972).

Sang-Arun et al. (2006) apresentam um estudo realizado em uma vila localizada na província de Chiang Rai, no norte da Tailândia, onde o crescimento populacional fez com que muitos grupos étnicos ocupassem áreas montanhosas e praticassem cultivos intensivos, para garantir sua sobrevivência. Áreas com declividades entre 12\% e 35\% foram ocupadas, de modo que representantes de instituições passaram a orientar essas famílias a construírem terraços de bancadas, entre outras práticas, para controlar a erosão. $O$ trabalho dos referidos autores buscou analisar a eficiência de quatro tipos de terraços adotados na área, assim como verificar as características da erosão do local. Os terraços se diferenciavam quanto ao camalhão, sendo o tipo A em nível, o B inclinado, o C em nível com bancadas e o $D$ inclinado com cobertura vegetal de ervas daninhas. A avaliação dos processos erosivos nas encostas indicou que os terraços $A$ e $B$ não foram eficientes no controle da erosão, dado a presença de sulcos, ravinas e até mesmo pequenas voçorocas nas encostas. Por outro lado, os tipos $C$ e $D$ foram eficientes, indicando que as bancadas e a cobertura vegetal foram efetivas na prevenção da erosão. Outro experimento foi realizado pelos autores buscando avaliar a efetividade da cobertura vegetal na redução de perdas do solo, cujo resultado indicou que o acúmulo do escoamento superficial em solos sem cobertura era 3,7 vezes maior do que nos solos cobertos com ervas daninhas e resíduos, dada a maior percolação da água da chuva no último caso. De um modo geral, pode-se concluir por esse trabalho que os terraços são estruturas bastante efetivas na prevenção da erosão, desde que o tipo adotado seja adequado às condições naturais do solo e do clima. 


\subsubsection{Sulcos e Camalhões em contorno}

Os sulcos e camalhões em contorno são uma prática muito eficiente de retenção das águas da chuva em pastagens, em áreas com chuvas escassas. Sua aplicação é recomendada em áreas em que o pasto ainda não esteja proporcionando uma cobertura eficiente, ou em terrenos muito inclinados, ou em áreas com superpastoreio. Essa estrutura atua retendo e distribuindo a água da chuva, favorecendo o desenvolvimento vegetal. Estruturalmente essa técnica consiste em um pequeno canal seguido de um pequeno dique de terra, que devem ser executados em contorno. Para realizar a marcação dos sulcos e camalhões devem-se dispor linhas niveladas distanciadas em 30 metros, sobre elas tiram-se linhas paralelas, de baixo para cima, onde serão feitos os sulcos e os camalhões. O espaçamento entre essas estruturas depende de características como infiltração, movimentação da água no solo, custo da construção e necessidade de maior ou menor conservação da água; podendo variar entre 1 e 10 metros, sendo mais comumente empregado com distância de 3 metros (Bertoni e Lombardi Neto, 1993).

\subsubsection{Caixa de Infiltração}

Cunha e Santos (1985) apresentam diversas medidas de prevenção de erosão em estradas de terra, sendo uma delas a caixa de infiltração ou retenção, também conhecida como sangradouro ou sangras laterais. Os autores recomendam que em regiões de solos arenosos muito erodíveis pode-se encaminhar a água das chuvas para essa estrutura, dispostas lateralmente as vias. Sua construção deve ser feita acompanhando-se o relevo, e estas devem estar espaçadas de modo a melhor captar a água que deve ser direcionada por canaletas. Porém, é necessário que ocorra manutenção periódica dessa estrutura, visando retirar a película de argila que se deposita no fundo, e que com o passar do tempo pode impedir a infiltração, e retirar os sedimentos de um modo geral, que causam o assoreamento da estrutura, e levam à perda de sua função.

No município de Brotas - SP foi identificada a utilização dessa estrutura em estradas de terra, que ligam pequenas propriedades rurais à área urbana. Na Figura 13 pode-se observar 0 emprego dessa medida de prevenção de erosão, ao longo da estrada não pavimentada. A acumulação da água de chuva ocorre visando seu armazenamento e infiltração. 


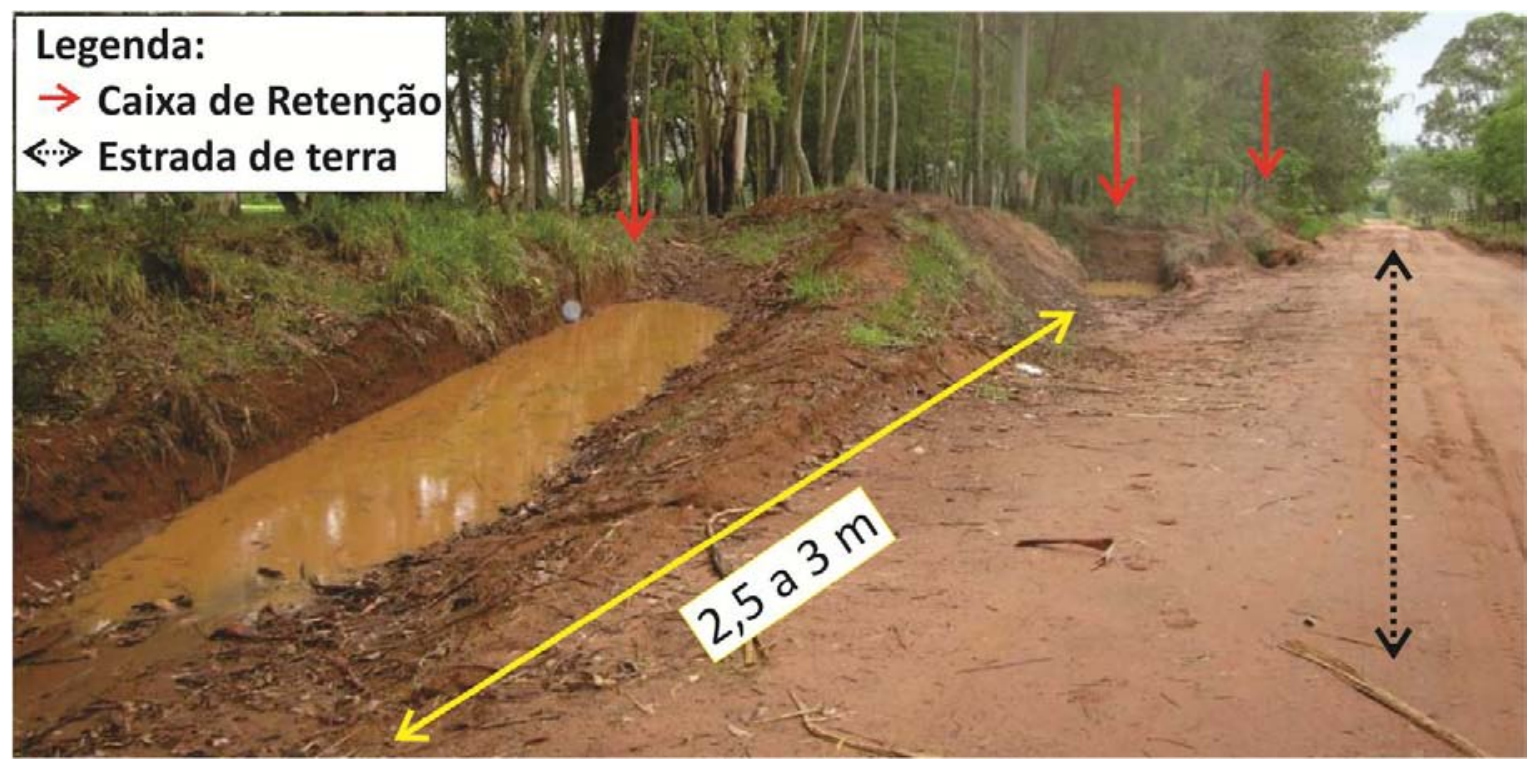

Figura 13: Caixas de Infiltração ou Retenção dispostas ao longo de uma estrada de terra no município de Brotas - SP.

\subsubsection{Aterramento}

Segundo Galerani et al. (1995), esse método consiste em aterrar novamente o local erodido. Porém essa técnica se apresenta como uma solução a ser utilizada quando o processo erosivo ainda está se iniciando, nos estágios de sulcos e ravinas. Quando o processo está adiantado, a solução pode ser considerada inviável economicamente. Iwasa e Fendrich (1998) afirmam, contudo, que quando bem empregada, essa medida implica na recuperação da erosão. De acordo com Souza (2001), os materiais empregados para o aterramento são os materiais inconsolidados, e dependendo das condições podem ser empregados os da própria região, com o cuidado para não acarretar o desenvolvimento de uma nova feição erosiva na área de empréstimo.

Kertzman, Pastore e Ridente Jr. (1995) alertam que em situações com afloramento de água subterrânea no fundo da erosão, o aterramento simples não é adequado. Segundo os autores, obras de controle de erosão que ignoram as águas subsuperficiais são responsáveis por inúmeros insucessos. Nesse contexto, Magalhães (2001) considera a contenção de voçorocas e ravinas como um processo que envolve uma série de obras, cujos objetivos são: desviar as águas pluviais, conter a água e o solo, proteger o solo, e evitar novas erosões. Dentre as inúmeras obras que podem ser empregadas, destaca-se o aterro das feições com drenos de fundo. A implantação dessa medida envolve a etapa de instalação do dreno no fundo da feição, seguida do aterramento do local erodido com solo, brita, seixos, pedras, entre outros materiais. Mattos 
(1995) complementa que com a execução da canalização, dentro da vala criada pela erosão, consegue-se o fechamento da voçoroca, por aterro controlado, o que permite retornar a condições próximas das anteriores. O autor enfatiza, porém, que essa medida deve ser utilizada apenas quando o valor do terreno, seja para uso rural ou para uso urbano, justifique o custo necessário para preenchimento de grandes feições erosivas.

Outra prática bastante empregada, embora não adequada, corresponde a disposição de resíduos sólidos no interior de feições erosivoas. Cavaguti (1995) afirma que durante décadas, quase todos os municípios brasileiros utilizavam o lixo no controle da erosão, acreditando estar resolvendo tanto o problema de disposição final quanto o da erosão do solo. Porém o autor apresenta uma série de consequências negativas dessa prática. Ele aponta para problemas como a formação de trincas e o desnivelamento da superfície em virtude do recalque causado pela redução do volume do lixo em decomposição, que favorecem a infiltração da água, e aceleram o processo erosivo. A alta permeabilidade do lixo e sua menor resistência à erosão levam à retomada do processo erosivo com maior intensidade, rompendo-se o aterro e surgindo novas feições, de dimensões maiores que as originais, o que envolve ainda o espalhamento de lixo à jusante. Há ainda o problema relacionado com o chorume, que contamina o solo e os recursos hídricos, de modo que pessoas, principalmente crianças, e animais podem se contaminar, gerando graves problemas e saúde.

Em seu trabalho, Gavaguti (1995) cita pelo menos cinco voçorocas no município de Bauru - SP que foram aterradas com lixo, constituindo-se assim, segundo o autor, boçorocaslixões. Nesse município o lixo coletado pelos caminhões compactadores era transportado e descartado à montante das erosões, sendo então empurrado para o seu interior por tratoresesteira. Quando toda a feição era preenchida, o lixo era recoberto com uma camada de solo menor que $30 \mathrm{~cm}$ e ligeiramente compactado. Em nenhum momento houve impermeabilização da base ou coleta do chorume, sendo que a contaminação do lençol freático foi comprovada, em áreas próximas a nascentes, que por sua vez também apresentaram contaminação. Além dos problemas relacionados à contaminação, o autor indicou a reativação de algumas feições, o que Ihe permitiu concluir que o uso do lixo urbano no controle da erosão não é adequado, podendo acarretar problemas ambientais e de saúde, caso mal executado.

Ferreira (2004) apresenta em seu trabalho o histórico de recuperação de feições erosivas situadas em uma área de aproximadamente $2 \mathrm{~km}^{2}$, pertencente à área urbana do município de São Pedro. A área possuía três grandes voçorocas principais, acompanhadas de sulcos e ravinas, em diferentes estágios de evolução. Ao longo do tempo, várias medidas de recuperação foram 
adotadas, sendo uma destas o aterramento acompanhado de obras de drenagem. Porém, verificou-se nessa área, que em diferentes períodos, para determinados eventos de chuva, as feições aterradas eram reativadas, devido à ausência ou subdimensionamento das estruturas de drenagem. Na Figura 14, por exemplo, observa-se uma feição erosiva, associada a uma das grandes voçorocas, que havia sido aterrada, e que foi reativada por um evento chuvoso, colocando em risco uma casa localizada na área. E ainda, na Figura 15 observa-se a formação de uma nova voçoroca devido ao rompimento de obras de drenagem pluvial de uma porção aterrada, que levaram ao solapamento da base.

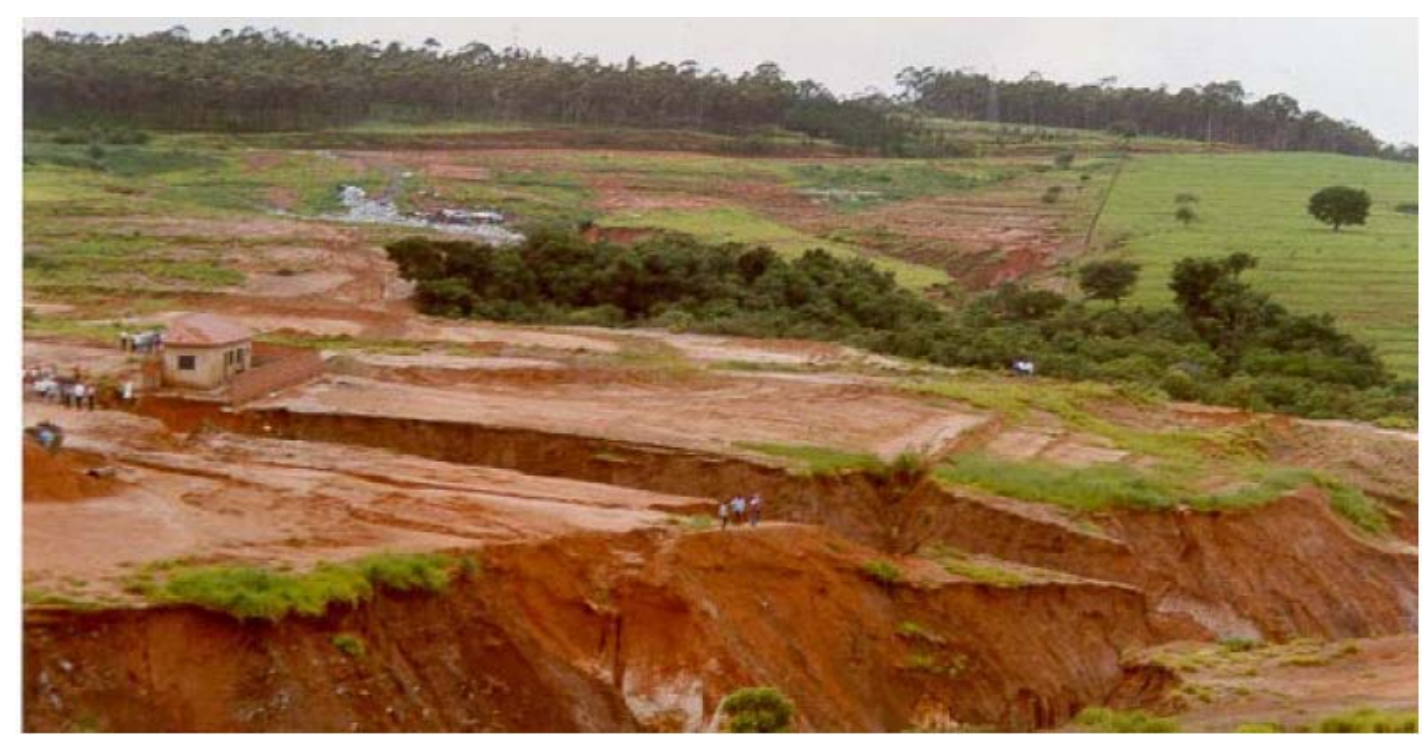

Figura 14: Feição erosiva que havia sido aterrada e foi reativada no município de São Pedro - SP (FERREIRA, 2004). 


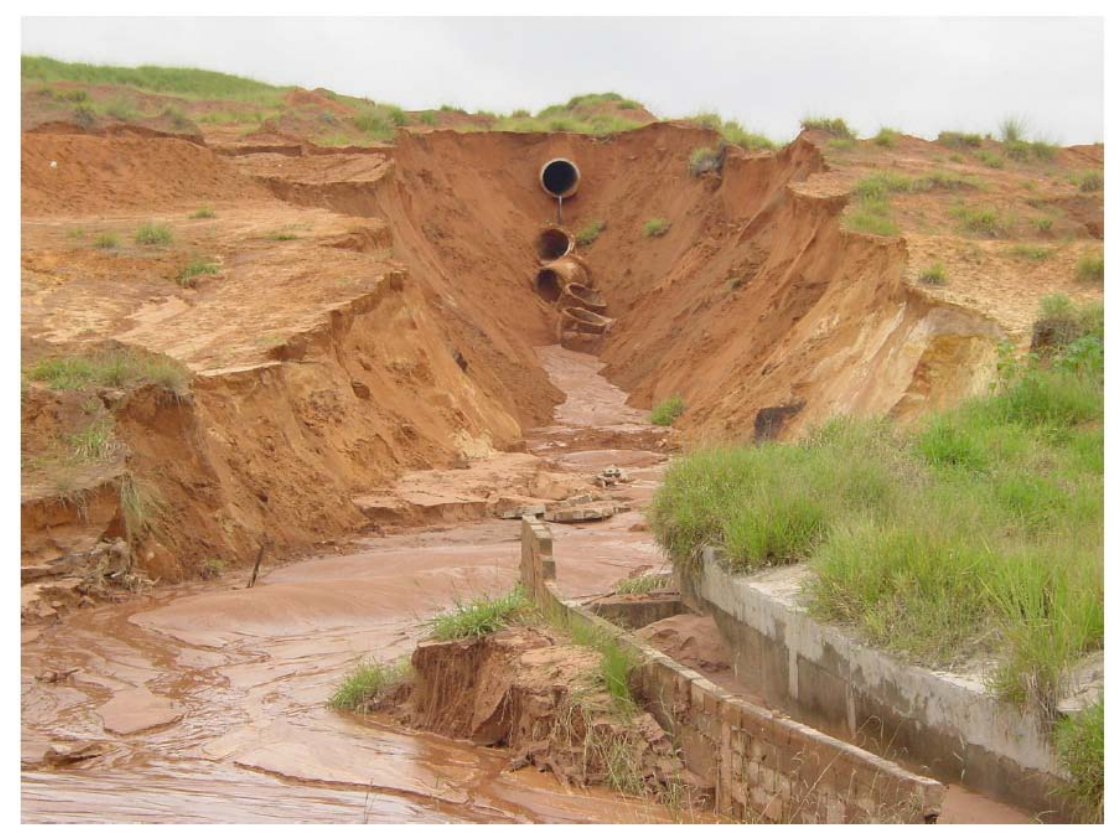

Figura 15: Voçoroca originada pelo rompimento de obras de drenagem pluvial associadas ao aterramento no município de São Pedro - SP (FERREIRA, 2004).

\subsubsection{Muro de Contenção}

Estruturas de contenção posicionadas na base dos taludes ajudam a estabilizá-los contra movimentos de massa e ainda protegem sua face contra a erosão. Existem vários tipos de estruturas que podem ser utilizadas, cuja seleção depende de considerações sobre as restrições do local, disponibilidade de materiais, aparência do muro, facilidade de construção, oportunidade de incorporar vegetação à estrutura e custos (GRAY e LEISER, 1982).

De acordo com Gray e Leiser (1982) e Gray e Sotir (1995), as estruturas de contenção podem ser classificadas em duas categorias: de gravidade e de não gravidade. As de gravidade são sub-classificadas em: estruturas de reforço (buttress structures), muros de gravidade coerente (coherent gravity walls), muros de blocos articulados (articulated block walls), (breast walls) e revestimentos (revetments). Essas estruturas resistem a forças laterais pelo seu peso. Os muros construídos de concreto projetado, aço, gabião ou terra armada se comportam como massas coerentes, enquanto que os muros de blocos articulados e de rochas são dispostos de forma que o atrito entre as unidades estruturais forneçam coerência e resistência ao cisalhamento e ruptura. Os principais tipos de muro de gravidade descritos pelos autores são:

- Muro de flexão e Muro com contraforte (Cantilever and Counterfort Wall): são estruturas construídas com concreto armado, que podem ser bastante altas, mas com economia de material em relação aos muros convencionais de alvenaria e concreto. 0 muro de flexão 
(cantilever) pode apresentar altura de até 9 metros, e o com contraforte (counterfort), 8 metros. O primeiro é reforçado na direção vertical para resistir a momentos de flexão (sendo este máximo na base do muro), e na direção vertical para prevenir rachaduras. Os contrafortes atrás do segundo tipo também são reforçados para resistir a tensões. Ambos são relativamente caros e requerem cuidados na construção. Essas estruturas estão representadas esquematicamente na Figura 16.

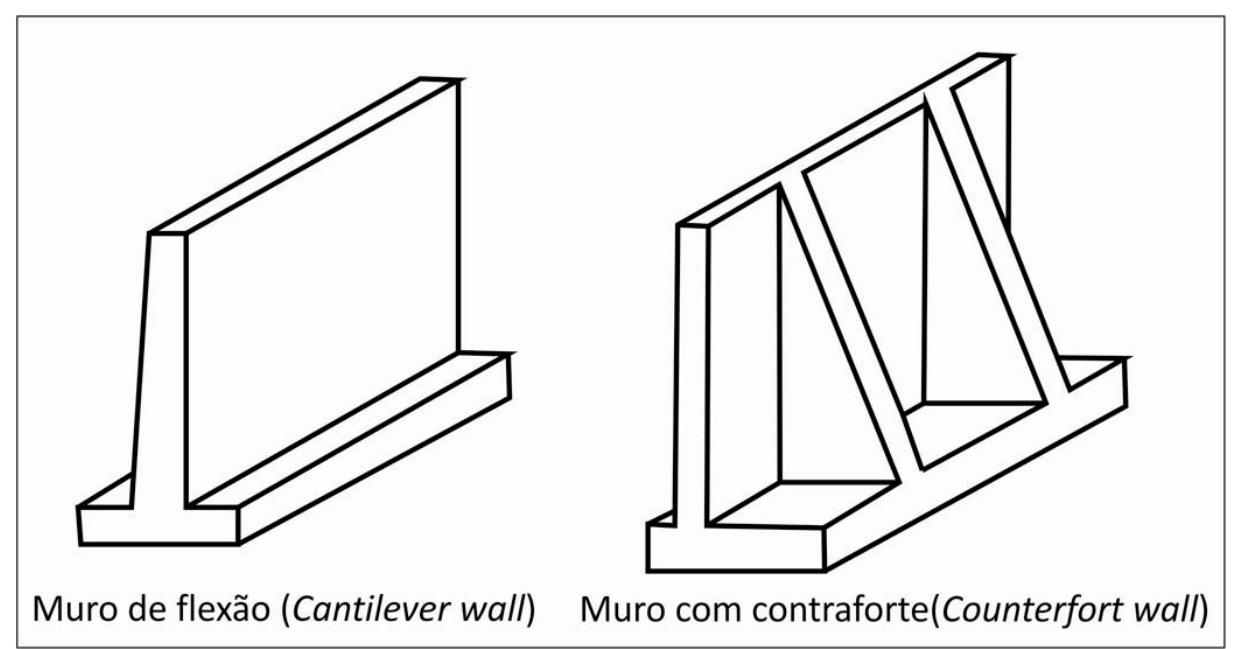

Figura 16: Esquema da estrutura dos muros de flexão e com contraforte (modificado de GRAY e LEISER, 1982)

- Muros em caixa (Crib Walls): consistem em cavidades, como caixas, formadas por estacas de madeira arranjadas e reforçadas com feixes de concreto ou de aço, preenchidas com solo ou rocha. Uma variação desse tipo compreende o muro de caixa (Bin wall) que consiste em caixas de aço parafusadas em unidades modulares e dispostas para formar um muro. Essa estrutura pode ser vertical ou inclinada, visando aumentar a estabilidade. Podem ser deixadas aberturas entre as células que permitam o estabelecimento de vegetação. Esse tipo de muro é relativamente barato. Na Figura 17 pode-se observar um esquema dessa estrutura, e na Figura 18 um exemplo de aplicação. 


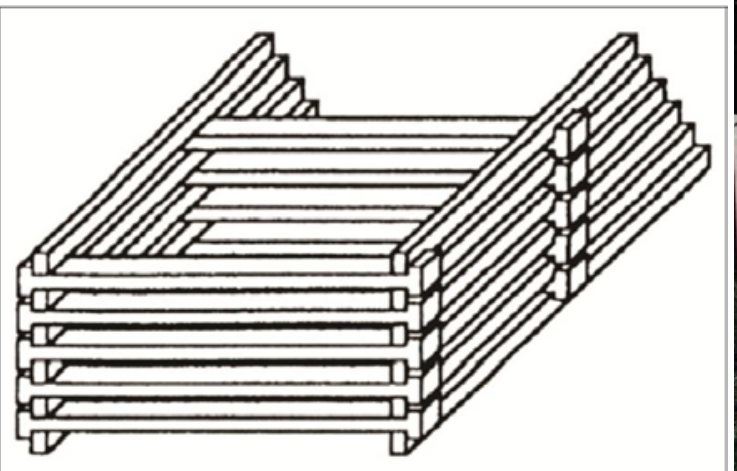

Muro em caixa (Crib wall)

Figura 17: Esquema da estrutura do muro em caixa (crib wall) (modificado de GRAY e LEISER, 1982).

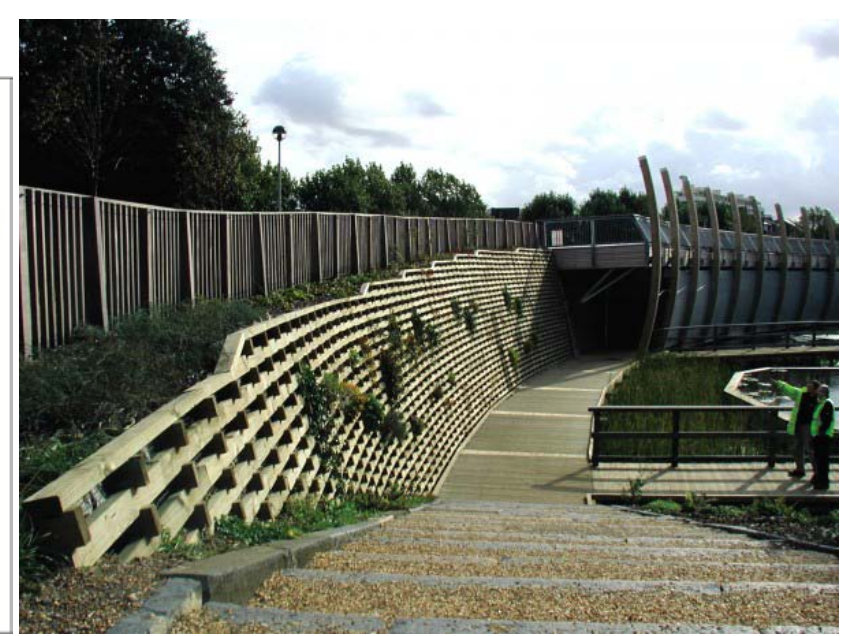

Figura 18: Aplicação do muro em fogueira (crib wall) no Mile End Park, Londres, com a aplicação de estacas de madeira e altura de 7,8 metros (http://www.phigroup.co.uk/tags/retainingwalls/mile-end-park-stepney-london)

- Muro de Gabião (Gabion Wall): os gabiões são cestos metálicos feitos com telas de arame grosso. As cestas são preenchidas com pedras ou rochas e empilhadas uma sobre as outras, na forma de um muro de gravidade. O Gabião é dependente da resistência ao cisalhamento das rochas que o preenchem, e que Ihe conferem estabilidade interna. Já a estabilidade externa, a forças laterais, é conferida pelo seu peso. Dada a porosidade do gabião, esta estrutura pode ser vegetada, sendo bastante flexível, fácil de lidar e barata.

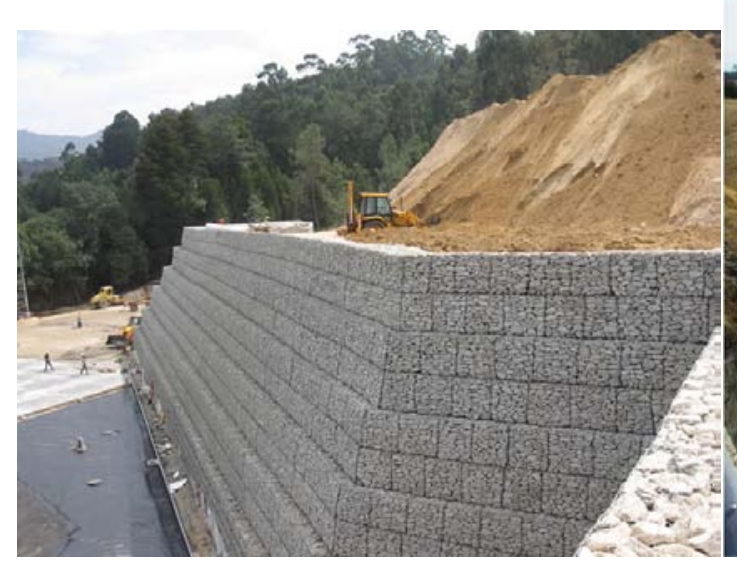

Figura 19: Exemplo de aplicação de um muro de gabião

(http://www.projectista.pt/produto/mu ros-de-gabioes-santos-mouta-2/)

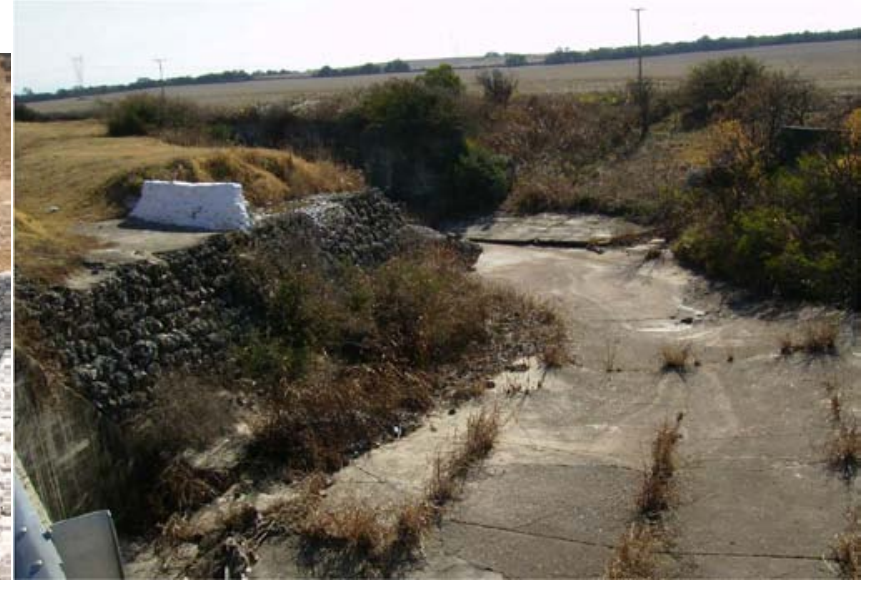

Figura 20: Rio Cuarto - Argentina. 
- Muro de Terra Armada (Reinforced Earth Walls): consiste em uma matriz granular reforçada com camadas de tiras metálicas. A tensão de cisalhamento que se desenvolve em um aterro reforçado é transferida por atrito de superfície para resistência à tração nas tiras de metal. As tiras estão ligadas aos elementos de cobertura, que são painéis finos de concreto préfabricados empilhados um sobre os outros. Pequenas tensões laterais atuam nos elementos de cobertura da frente da estrutura, sendo que a maior parte da tensão do solo é retomada em resistência à tração ao longo das tiras de reforço. O volume reforçado pode ser considerado e analisado como uma estrutura de gravidade.

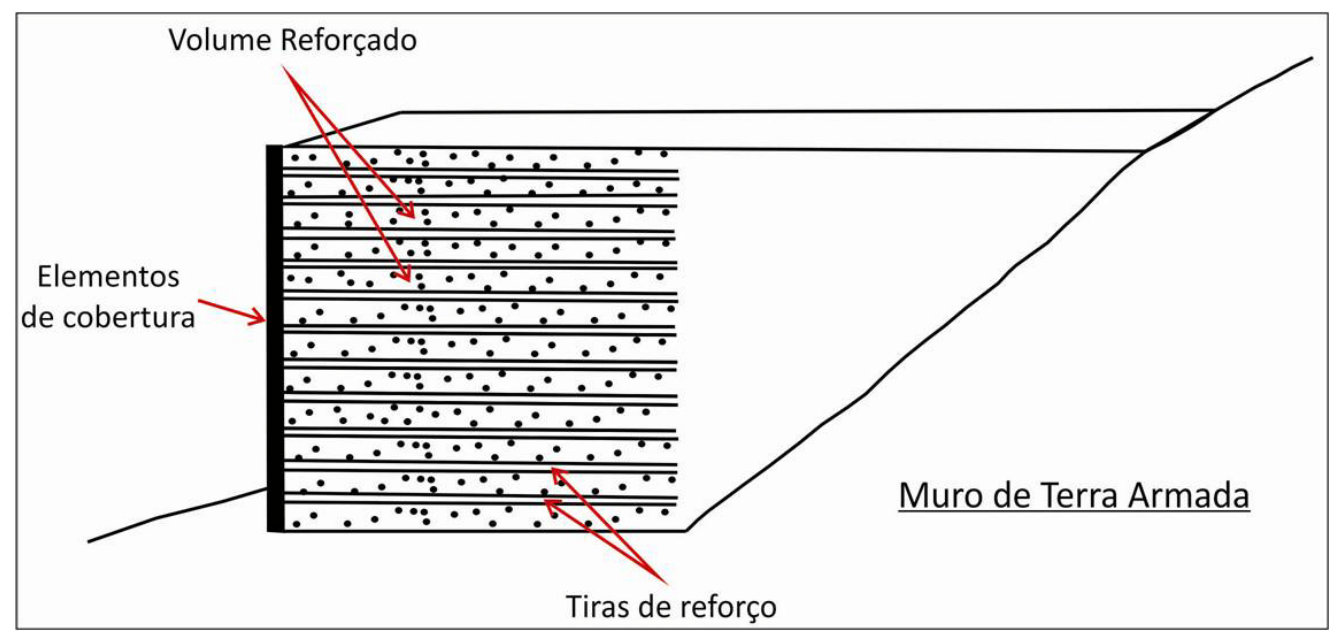

Figura 21: Esquema da estrutura do muro de terra armada (modificado de GRAY e LEISER, 1982).

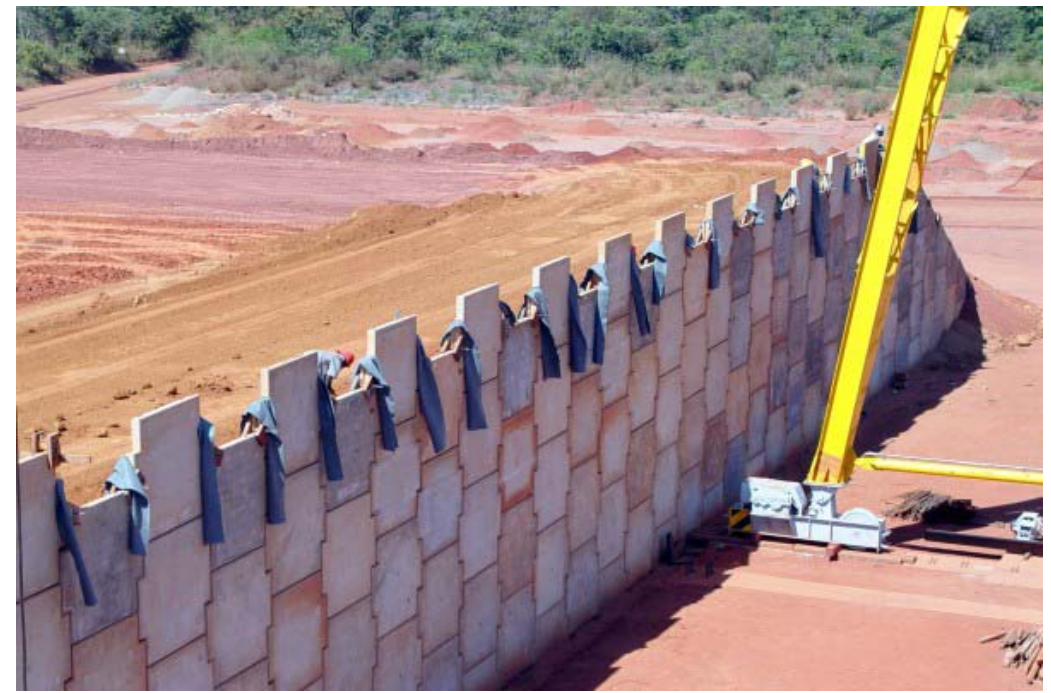

Figura 22: Aplicação de um muro de terra armada, enfatizando os elementos de cobertura (http://www.terraarmada.com.br/projetos. php?ord=alfa\&propg $=8 \& x=753125 \& a n c=1$ ). 
- Muros de terra estabilizados mecanicamente (Mechanically Stabilized Earth Walls): Essa estrutura emprega diferentes tipos de inclusões, de vários formatos e propriedades, utilizadas para reforçar muros de contenção. As inclusões podem ser geogrelhas de polímeros ou telas soldadas a filamentos de fibras de poliéster. Os aterros reforçados com inclusões são conhecidos como "estabilizantes mecânicos de solo". O muro de arame soldado, por exemplo, é uma estrutura composta de arame e solo granular. As seções de malha de arame, com formato de " $L$ " são dispostas e conectadas entre sucessivas aberturas no aterro. A malha de arame proporciona tanto o reforço no aterro quanto contenção na face do muro, constituindo-se uma estrutura que compartilha características dos gabiões e dos muros de terra armada. Muros com geogrelhas utilizam reforços poliméricos, bastante resistentes e flexíveis, que podem ser construídos envolvendo-se a geogrelha em sucessivas elevações do aterro, sem a necessidade de um revestimento separado. Ambos os tipos de muros são de relativo baixo custo, fáceis de serem erguidos, e bem adaptados ao tratamento vegetado.

- Muro de alvenaria de pedra e Muro de blocos articulados (Rock Breast Walls and Articulated Block Walls): ambos podem ser considerados como estruturas de gravidade que resistem a forças laterais, principalmente pelo seu peso. Deve haver atrito suficiente ou articulação entre as unidades (rochas ou blocos) para resistir à ruptura por cisalhamento. Esses muros devem ser erguidos em uma base firme e são dispostos contra a encosta com pequenas quantidades de material atrás deles. Nenhum dos dois tipos é designado para resistir a grandes tensões laterais, de modo que sua altura é limitada. Suas principais funções são proteger a base da encosta contra o desgaste do fundo e prover resistência lateral. Eles são usualmente construídos com inclinação suficiente para aumentar a estabilidade e diminuir os esforços laterais. São bastante porosos e permitem que sejam incorporadas plantas nos vãos da estrutura. 


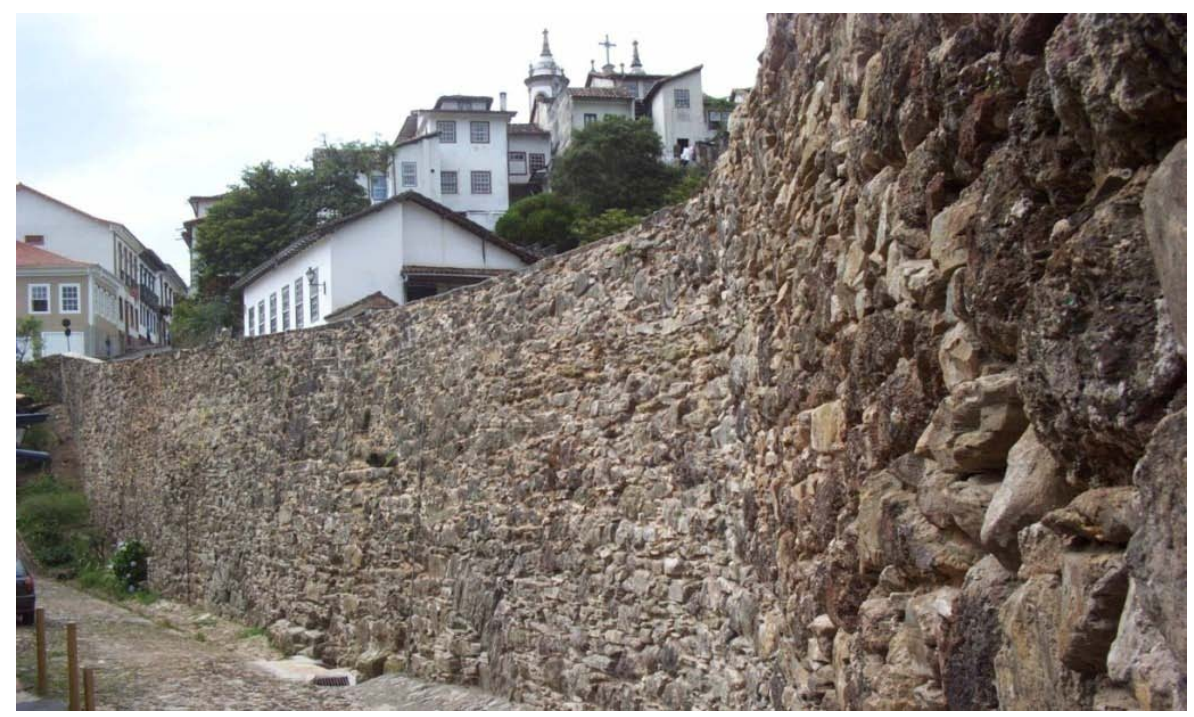

Figura 23: Muro de blocos de rocha em Ouro Pedro- MG.

- Muro de Estacas e Muro Atirantado (Pile and Tie-Back Walls): são empregados como muros de retenção em situação onde restrições e condições da fundação limitem o uso de estruturas de gravidade. Os muros de estacas são constituídos de linhas de pilhas de cilindros de concreto. Essa estrutura tem sido utilizada para suportar estradas de pequeno volume que cortam terrenos íngremes, caracterizados por solos fracos e superficiais, sustentados por uma zona de rocha alterada que aumenta em competência, com a profundidade. Os muros atirantados, por sua vez, consistem em revestimentos finos e flexíveis conectados a uma rede de tirantes. Os tirantes podem estar conectados a placas encaixadas ou blocos de concreto, ou podem estar acimentados no local. 


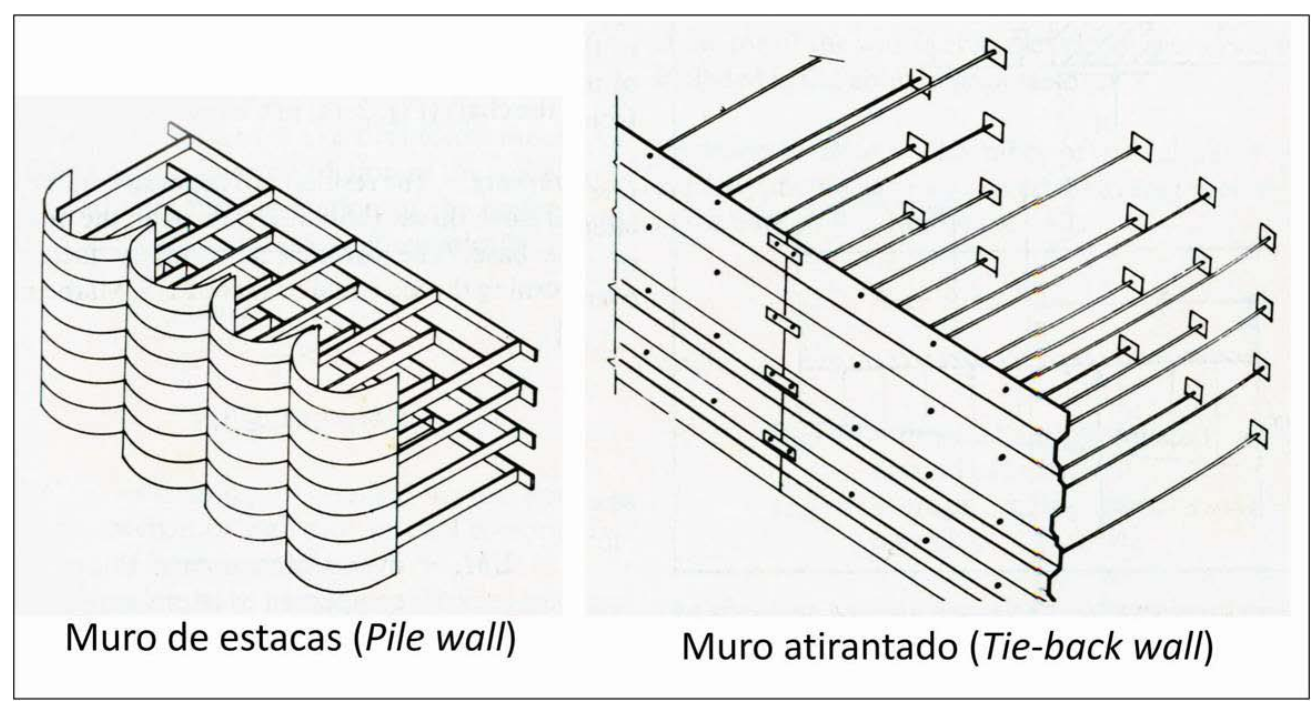

Figura 24: Esquema da estrutura de muros de estacas e do muro atirantado (modificado de GRAY e LEISER, 1982).

Os critérios de desenvolvimento dos muros de gravidade podem ser descritos em projetos padrões, que são desenvolvidos para cada tipo de muro de retenção, com base nos princípios de mecânica dos solos e experiências anteriores. A eficiência dessa estrutura depende de questões de estabilidade externa e interna. No que se refere à componente externa, são necessários cálculos para determinar a estabilidade do muro contra o deslizamento da base, tombamento, capacidade de carga e ruptura da encosta. Quanto à estabilidade interna, os muros de retenção devem ser capazes de resistir a tensões a que estes são submetidos, sendo que sua resposta varia de acordo com o tipo de estrutura empregada. Além disso, é necessária a proteção dos componentes estruturais contra a ação do intemperismo, de raízes, e da corrosão. (GRAY e SOTIR, 1995).

Muitos muros de contenção podem ser construídos para condições específicas de inclinação e carregamento, e com diferentes alturas. Existem diferentes guias construtivos, que variam de acordo com o tipo de muro adotado, e com as condições locais em que serão empregados. Por outro lado, há fatores e condições gerais que devem ser sempre consideradas, como a altura máxima do muro, condições de sobrecarga, resistência e acabamento dos elementos estruturais, inclinação do muro, sequência de montagem, tipos de fixadores ou conectores, gradação e compactação do material de preenchimento e aterro, condições de fundação no contato muro e solo, e condições da presença da água no solo (GRAY e LEISER, 1982). 


\subsubsection{Cordões de Nível}

Os cordões de nível consistem em bancos de terra, de 1,5 a 2 metros de largura, posicionados ao longo da encosta para agir como uma barreira para o escoamento superficial, formando uma área de armazenamento a montante, e quebrando a encosta em segmentos menores, buscando diminuir o escoamento superficial. Essa técnica é adequada para declividades de 1 a $7^{\circ}$ e são muito utilizadas em pequenas propriedades nos trópicos. Os cordões são geralmente espaçados de 10 a 20 metros, sendo geralmente construídos de maneira simples. Não são necessárias especificações precisas para o seu desenho, e desvios na sua inclinação de até 10\%, no contorno, são permitidos (MORGAN, 1995).

Em um distrito pertencente ao norte da Etiópia, proprietários agrícolas utilizam diferentes técnicas de conservação do solo e da água, sendo uma delas conhecida como cordões de pedras, empregados especialmente entre os anos de 1991 e 2002, com configuração igual a representada na Figura 25. Nesse período os fazendeiros construíram cordões em contorno, com altura variando de 0,3 a 1,2 metros. Os cordões eram compostos por fragmentos de rocha de 10 a $40 \mathrm{~cm}$ de diâmetro, preenchidos com fragmentos menores, de 5 a $10 \mathrm{~cm}$ de diâmetro, e finalizados com uma cobertura de solo rico em fragmentos de rocha (diâmetro médio igual a 2 $\mathrm{cm}$ ), que atua como um filtro, retendo o sedimento, em eventos de chuva mais intensos (Figura 26). Os materiais empregados nesse local variavam entre fragmentos de basalto, areia ou fragmentos de calcário. A utilização dessa medida envolvia atividades de manutenção dos cordões, sempre que necessário, através da reconstrução de partes rompidas, e do aumento de sua altura, em cerca de $8 \mathrm{~cm}$, conforme o assoreamento a montante da estrutura. Estudos realizados na área constataram que a utilização dessa medida diminuiu em $68 \%$ a perda de solo por erosão, e ainda, contribuíram para que a infiltração e a produtividade fossem levemente elevadas. Outro benefício associado a essa técnica consiste na redução da declividade do terreno entre os cordões, devido à acumulação de sedimento a trás dessas estruturas. Verificouse que em alguns pontos a declividade foi suavizada em até $3 \%$, num período de 3 a 21 anos, o que em geral beneficia a prática agrícola local (NYSSEN et al, 2007). 


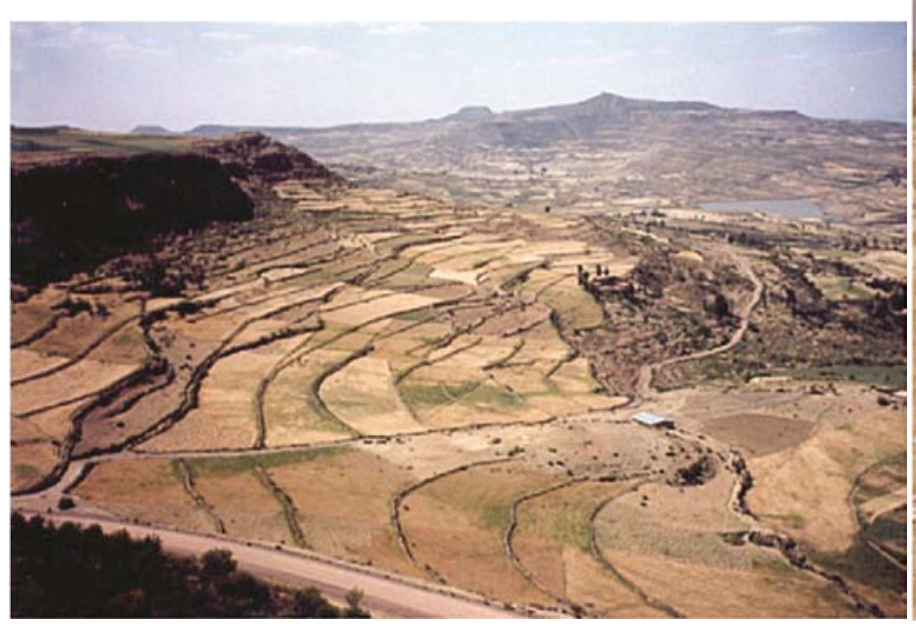

Figura 25: Cordões de pedras em área agrícola da Etiópia (NYSSEN et al, 2007).

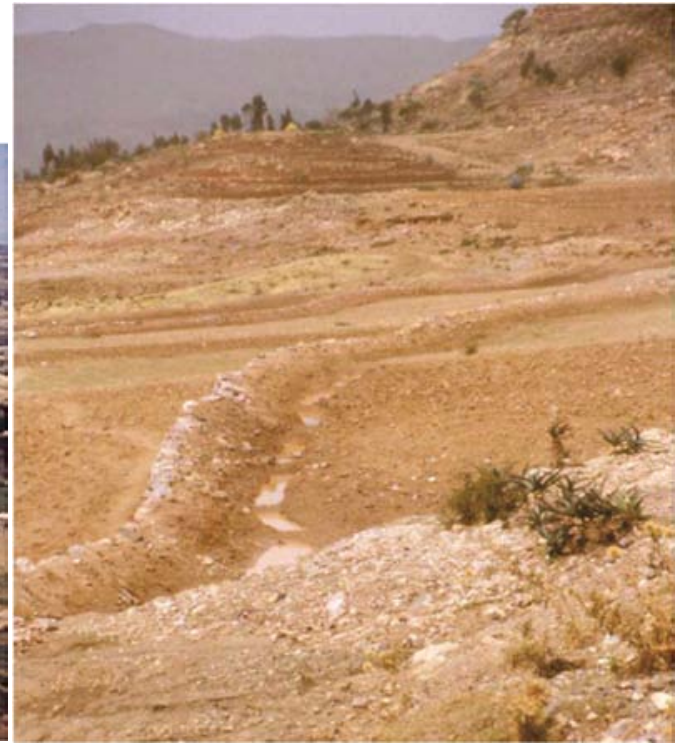

Figura 26: Cordão de pedras preenchido com solo rico em fragmentos de rocha (NYSSEN et al, 2007).

\subsubsection{Retaludamento}

O retaludamento é um tipo de obra que ocorre, muitas vezes, associado ao aterramento de erosões. Sua finalidade é estabilizar os taludes contra a erosão pluvial e possíveis escorregamentos. Essa técnica é empregada por meio de serviços de terraplanagem, ou de cortes e aterros, associados a medidas de proteção superficial, como a revegetação e estruturas de drenagem superficial (IWASA e FENDRICH, 1998).

O processo de retaludamento consiste na terraplanagem, através da qual se alteram, por cortes ou aterros, os taludes originalmente existentes (CARVALHO, 1991). A alteração busca, basicamente, reduzir a altura e o ângulo de inclinação de uma encosta ou talude de corte. $A$ vantagem na mudança da geometria consiste no fato de esta ser permanente, melhorando assim a estabilidade do maciço (RODRIGUES e LOPES, 1998).

O retaludamento pode ainda ser empregado para suavizar os taludes de uma erosão, uma vez que as vertentes internas das voçorocas são bastante íngremes, o que exige a diminuição da declividade, tanto para fornecer estabilidade aos taludes, reduzindo a ação da gravidade, quanto para facilitar o plantio de vegetação. Mas a aplicação dessa técnica para recuperação de voçorocas, só deve ocorrer após a implantação de uma completa rede de drenagem no fundo da feição. É recomendado ainda que os novos taludes tenham declividades 
de 2:1, e que sejam protegidos por obras de drenagem superficial, como canaletas (FILIZOLA et al, 2011).

Em alguns casos é necessária a reconstrução total do talude, que deve ocorrer tomandose uma série de cuidados, como os relativos à escolha da jazida de solo adequada; ao tratamento do solo da jazida; à limpeza do terreno para preparo da fundação; à estocagem do solo superficial para utilização na faze final do aterro; à preparação do contato entre o solo e o aterro na forma de degraus; à preparação do sistema de drenagem de base; e à compactação adequada do aterro (CARVALHO, 1991).

Guidicini e Nieble (1976) apontam que cuidados devem ser tomados ao se realizar o retaludamento, ou outro tipo de intervenção na geometria de taludes. Para os autores, acrescentar sobrecargas na porção superior, ou retirar parte da massa na porção inferior podem gerar condições de instabilidade. No que se refere ao retaludamento, quando executado para aumentar a estabilidade da massa, pode resultar em uma diminuição das forças solicitantes, e conduzir à ruptura; e ainda, pode levar à diminuição da pressão normal atuante no plano de ruptura potencial, e consequentemente da força de atrito resistente (GUIDICINI e NIEBLE, 1976).

De acordo com Oliveira (2006), existem quatro formas principais de se modificar a geometria de um talude para melhorar sua estabilidade. A primeira consiste em eliminar a massa instável, ou potencialmente instável, devendo ser empregada apenas em situações extremas, em que se prove que a nova configuração será estável. A segunda forma consiste em retirar material da parte superior da massa potencialmente deslizante, dado que essa porção é a que mais favorece situações de instabilidade, apresentando menor resistência, dada à elevada declividade dessa porção. A aplicação dessa metodologia é indicada para situações em que o material seja de fácil escavação, e fácil acessibilidade. A terceira forma indicada pelo autor emprega blocos de terra ou enrocamento no pé do talude, de forma que o peso conferido leve a um aumento nas tensões normais na parte inferior da superfície de deslizamento, aumentando sua resistência. E finalmente, a quarta maneira de conferir estabilidade aos taludes compreende a disposição de bermas intermediárias. Essa técnica apresenta benefícios extras, pois facilita o processo construtivo e as operações de manutenção, retêm a queda de fragmentos de rocha, e permitem a colocação de várias estruturas de drenagem que diminuem a ação erosiva da água de escoamento. A estabilidade alcançada por um talude com bermas é muito superior à de um talude contínuo de igual altura e com ângulo igual ao do degrau.

Sponga e Coelho (2001) apresentam a recuperação de uma área degradada por erosão, que envolveu um conjunto de técnicas simples, entre elas o retaludamento. A área afetada é 
uma Reserva Biológica, denominada Jardim Botânico, localizada na cidade de Goiânia - GO. O processo de urbanização nas adjacências do local não envolveu a construção de galerias de drenagem pluvial, de modo que com o tempo, a erosão que existia no local, e que apresentava dimensões modestas, evoluiu de para uma voçoroca com ramificações, chegando a interceptar o lençol freático, conforme pode ser observado na Figura 27.

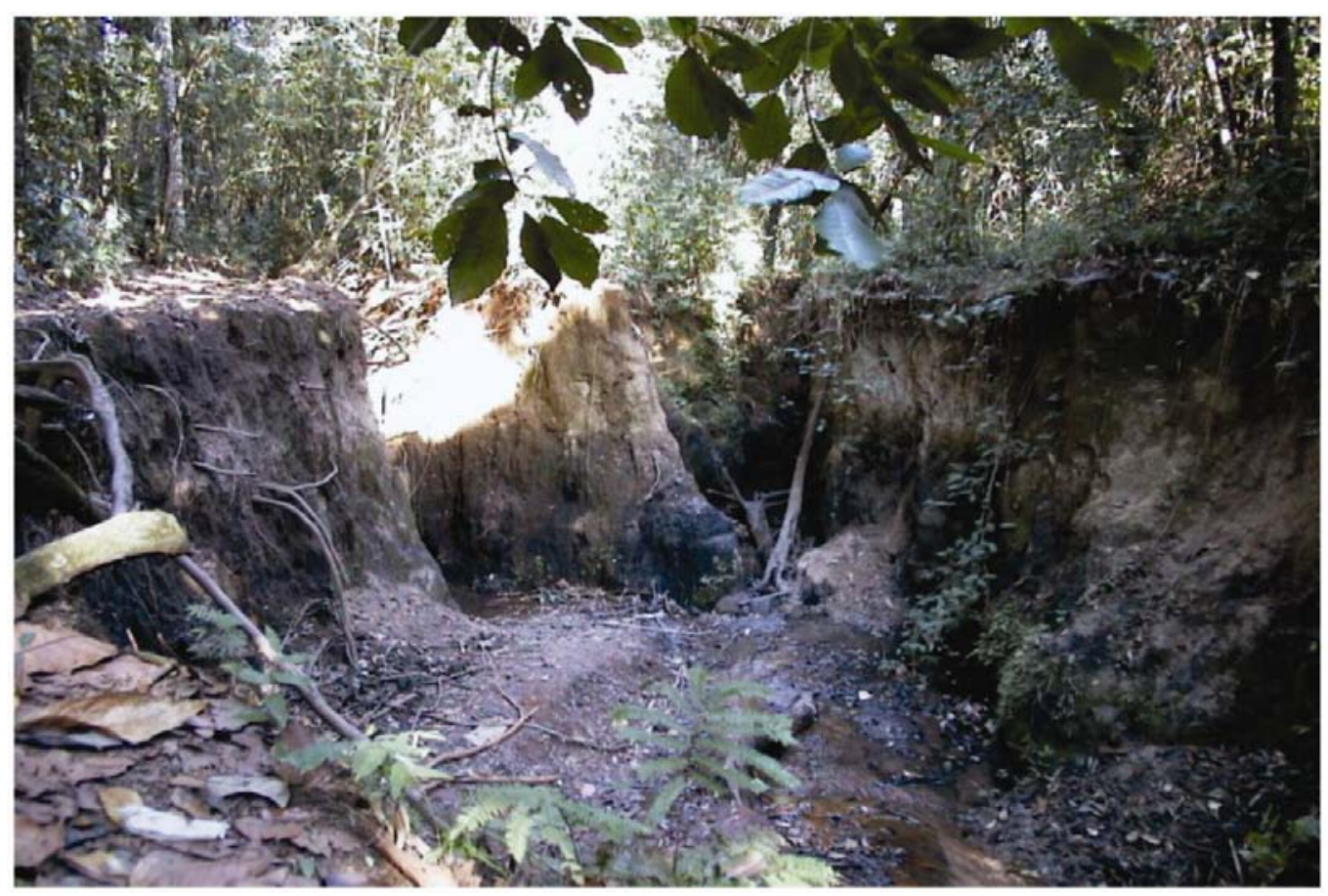

Figura 27: Voçoroca do Jardim Botânico de Goiânia - GO, com interceptação do nível freático (SPONGA e COELHO, 2001).

Nesse contexto, foi executado um projeto de recuperação, que se iniciou com a construção de um sistema de drenagem de fundo, que buscava captar vários pontos de afloramento do lençol subterrâneo. Aliado à drenagem de fundo, foi construído um canal principal, com material natural, e duas calhas, constituídas de madeira e pedras (Figura 28). Após a conclusão do sistema de drenagem, como é recomendado, foi realizado o retaludamento das paredes da feição, com geometria variável (Figura 29). Nos taludes modificados foi ainda aplicada a hidrossemeadura e uma manta antierosiva biodegradável, cuja finalidade era conferir estabilidade. Esse projeto foi bastante eficiente, dado que atuou na eliminação do problema relacionado à drenagem pluvial, e ainda estabilizou a voçoroca, recuperando-a adequadamente, como indicado na Figura 30. 


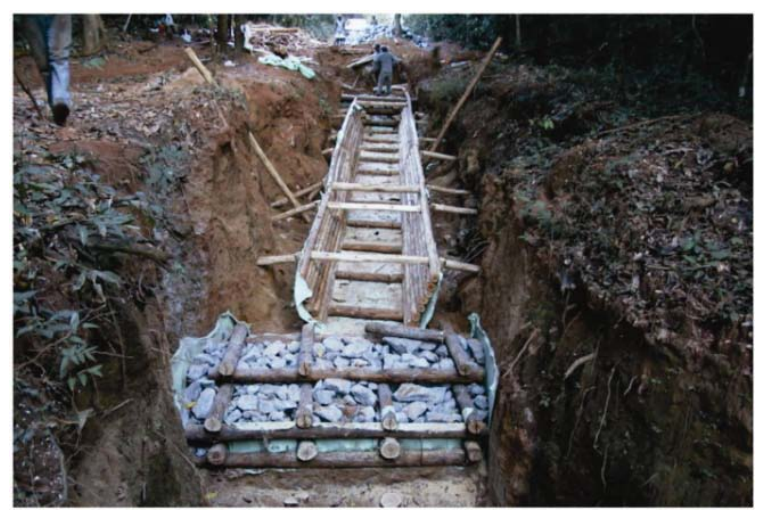

Figura 28: Construção do canal principal e da canaleta, integrantes do sistema de drenagem da recuperação da voçoroca do Jardim Botânico de Goiânia - GO (SPONGA e COELHO, 2001).

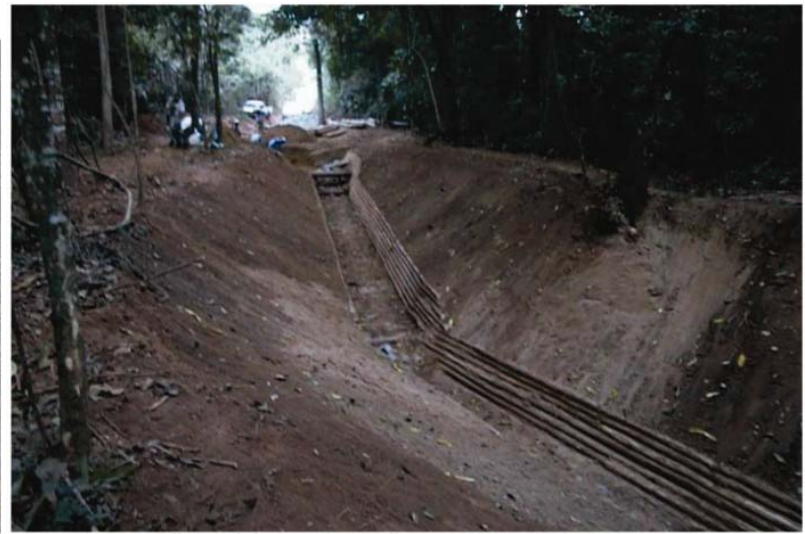

Figura 29: Retaludamento das paredes da voçoroca no entorno do canal principal da feição do Jardim Botânico de Goiânia - GO (SPONGA e COELHO, 2001).

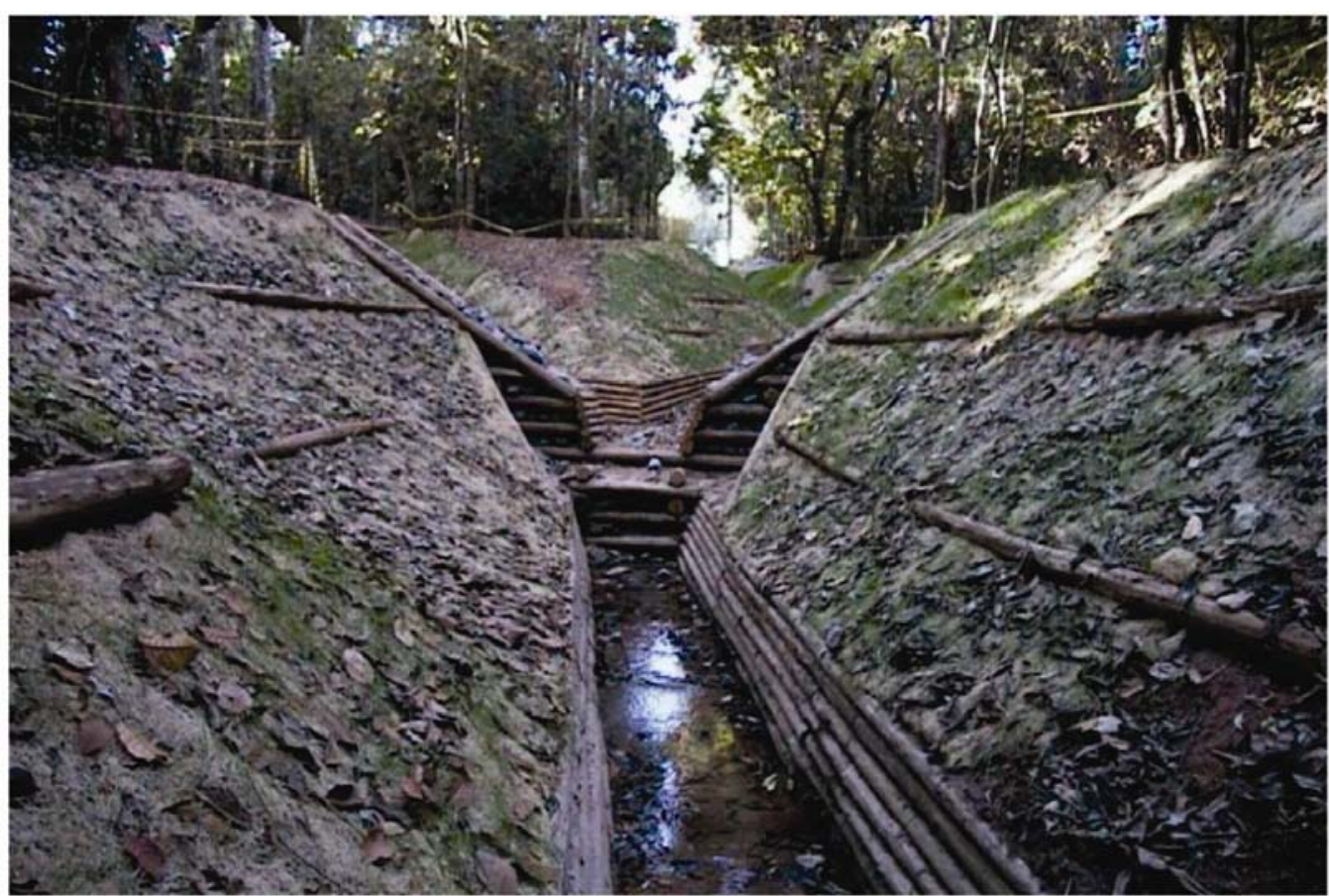

Figura 30: Voçoroca do Jardim Botânico de Goiânia - GO totalmente recuperada (SPONGA e COELHO, 2001).

\subsubsection{Obras de drenagem}

Nas áreas urbanas, o principal objetivo de medidas de controle de erosão é manter a integridade das cidades, sendo que os métodos adotados variam de acordo com as necessidades do local. As principais técnicas de controle de erosão na área urbana envolvem soluções 
individuais, ou até mesmo grandes projetos, tais como a manutenção de áreas permeáveis dentro dos lotes, e estruturas de macro e microdrenagem (GALERANI et al, 1995).

O sistema de drenagem, de um modo geral, consiste num conjunto da infraestrutura existente em uma cidade para realizar a coleta, o transporte e o lançamento final das águas superficiais. É constituído por uma série de medidas que visam a minimizar os riscos a que estão expostas as populações, diminuindo os prejuízos causados pelas inundações e possibilitando o desenvolvimento urbano de forma harmônica, articulada e ambientalmente sustentável (FEAM, 2006).

A microdrenagem, nesse contexto, consiste em estruturas de condução das águas superficiais, sendo de grande importância no controle da erosão, uma vez que evita o escoamento direto sobre o solo (GALERANI et al, 1995). Complementando esse princípio, Bidone e Tucci (1995) apontam que as estruturas de microdrenagem consistem em condutos pluviais em nível de loteamento ou de rede primária urbana, sendo os principais elementos indicados a seguir.

- Galeria: consiste em canalizações públicas usadas para conduzir águas pluviais provenientes das bocas-de-lobo e das ligações privadas (BIDONE e TUCCl, 1995). São canalizações subterrâneas que integram o sistema de drenagem ao sistema urbano, possibilitando a livre circulação de veículos e pessoas (DNIT, 2004). É recomendado que essa estrutura apresente um diâmetro de, no mínimo, 0,30 m, para seções circulares; devendo ser projetada para funcionar a seção plena com a vazão de projeto. A velocidade máxima admissível varia de acordo com o material empregado na rede, sendo admissível velocidades entre $5 \mathrm{~m} / \mathrm{s}$ e 0,6 m/s, para tubos de concreto, por exemplo (BIDONE e TUCCI, 1995).

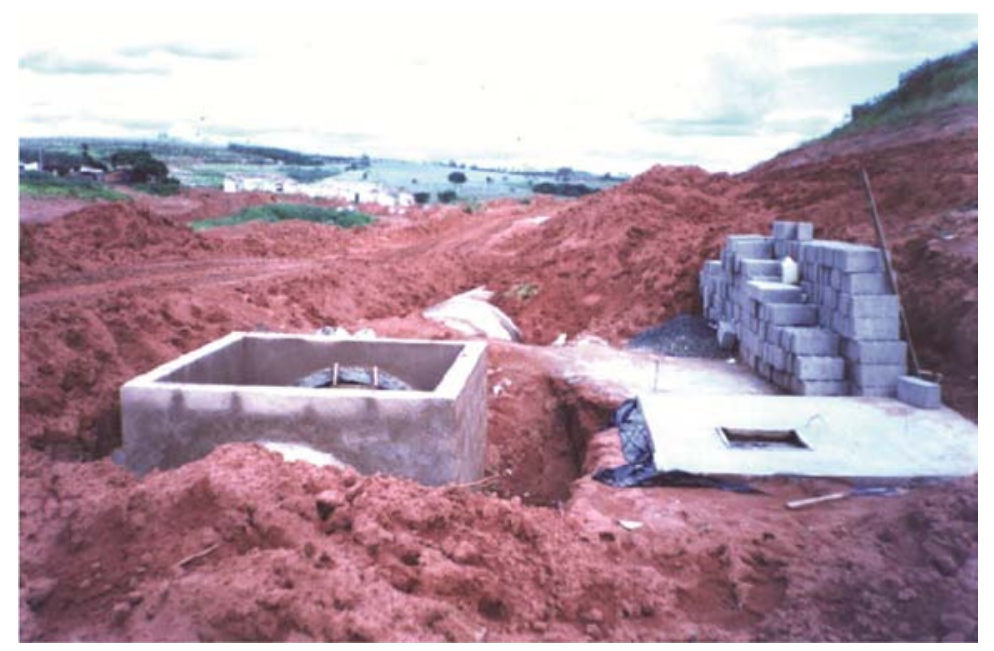

Figura 31: Exemplo de galeria em construção em São Pedro - SP (FERREIRA, 2004). 
- Poço de visita: é um dispositivo localizando em pontos convenientes do sistema de galerias, que permite a mudança de direção, de declividade e de diâmetro, e que permite a limpeza das canalizações (BIDONE e TUCCI, 1995; DNIT, 2004). Essa estrutura apresenta uma abertura na parte superior, ao nível do terreno, e possui dois compartimentos distintos, a chaminé e o balão, que são construídos de tal forma a permitir a entrada do operador e a execução de manobras por este, em seu interior (FERNANDES, 2002). A porção de galeria situada entre dois poços de visita é denominada trecho.

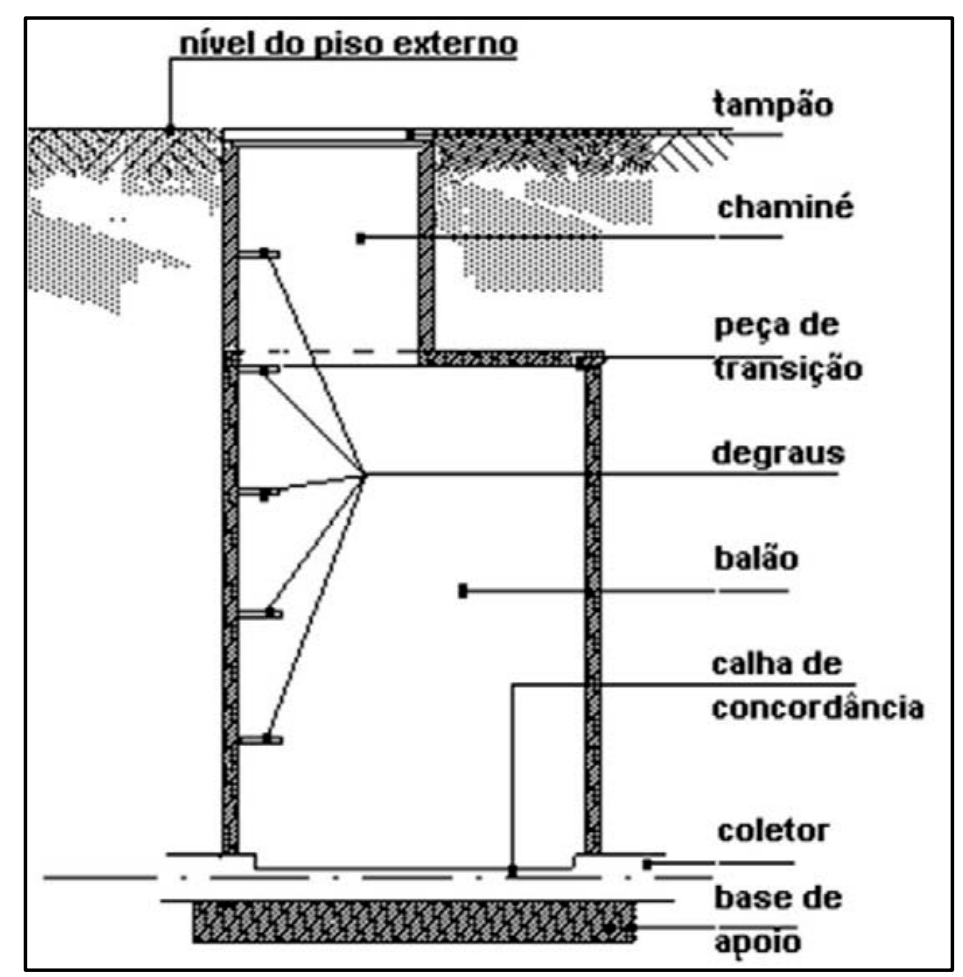

Figura 32: Esquema de um poço de visita (FERNANDES, 2002).

- Caixa de ligação: esse tipo de estrutura é empregado quando é necessária a utilização de bocas-de-lobo intermediárias para evitar a chegada de mais de quatro tubulações em um mesmo poço de visita. Sua função é a mesma do poço de visita, porém não são visitáveis (BIDONE e TUCCI, 1995). 


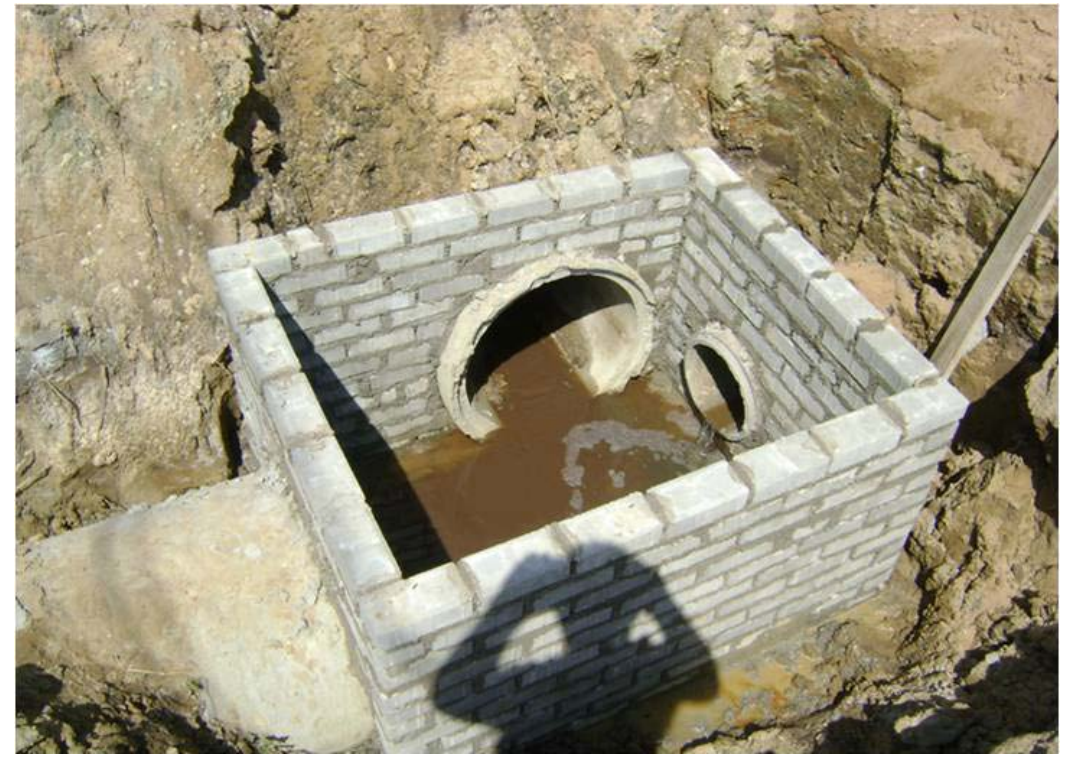

Figura 33: Exemplo de uma caixa de ligação (http://www.jtbterraplenagem.com.br/obras.html).

Bocas-de-lobo: Bidone e Tucci (1995) definem essa estrutura como dispositivos localizados em pontos convenientes, nas sarjetas, para captação das águas pluviais e posterior encaminhamento para estruturas subterrâneas. As bocas-de-lobo, ou bocas coletoras, podem ser classificadas quando à estrutura de abertura, sendo assim laterais, gradeadas com barras, combinadas ou múltiplas. No que se refere à localização ao longo das sarjetas, estas podem estar dispostas em pontos onde sua capacidade atinja o limite máximo, denominadas intermediárias. Podem ser dispostas nas esquinas dos quarteirões, buscando evitar o prolongamento do escoamento pelo leito dos cruzamentos, sendo assim conhecidas como de cruzamento; e ainda podem ser classificadas como bocas coletoras de pontos baixos, caracterizadas por receberem contribuições por dois lados, visto que se situam em pontos onde há a inversão côncava da declividade de rua, ou seja, na confluência de duas sarjetas de um mesmo lado da rua. E finalmente, quanto ao funcionamento, dependendo da altura da água na sarjeta e da abertura da boca coletora, elas podem ser do tipolivre, que funciona como vertedor, ou do tipo afogada, a que funciona como orifício, sendo estas mais frequentes em pontos baixos e, na maioria, com grades (FERNANDES, 2002).

Vale ressaltar que a disposição dessas estruturas deve se dar de maneira a conduzir adequadamente as vazões superficiais para as galerias. Em pontos mais baixos devem-se dispor essas estruturas para evitar a criação de zonas mortas com alagamentos e águas paradas (BIDONE e TUCCI, 1995). 


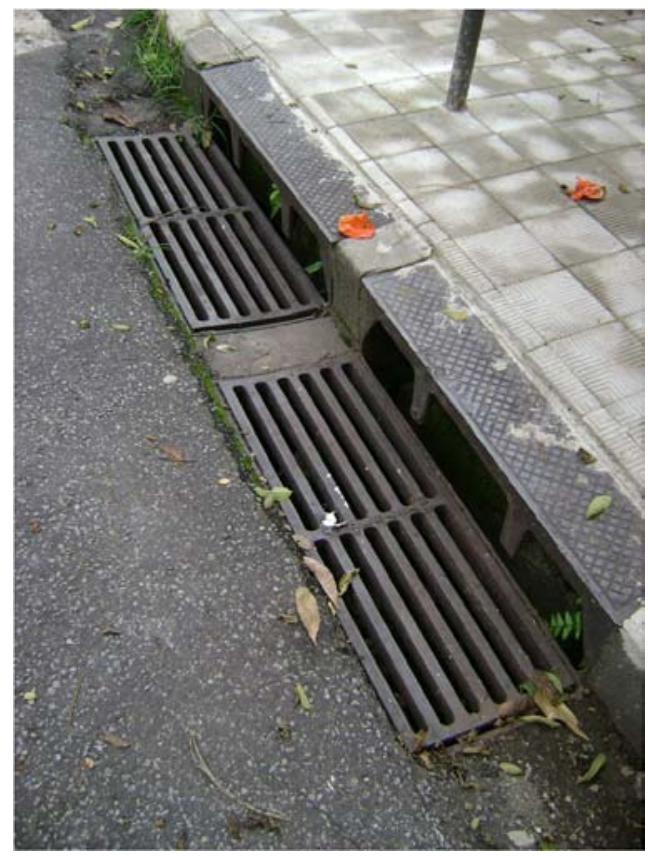

Figura 34: Exemplo de boca-de-lobo gradeada (http://pt.wikipedia.org/wiki/Ficheiro:Boca de lobo.JPG).

- Tubos de ligações: são canalizações destinadas a conduzir as águas pluviais captadas nas bocas-de-lobo para as galerias ou poços de visitas (BIDONE e TUCCI, 1995; site).

- Meios-fios: compreendem elementos de pedra ou concreto, dispostos entre o passeio e a via pública, paralelamente ao eixo da rua, e com sua face superior no mesmo nível do passeio (BIDONE e TUCCI, 1995).

- Sarjetas: são faixas de via pública, paralelas e vizinhas ai meio-fio, que formam uma calha receptora das águas pluviais, que incidem sobre as vias públicas e que para elas escoam. Consiste basicamente em um canal longitudinal, em geral triangular, que coletam e conduzem as águas até pontos de coleta (BIDONE e TUCCI, 1995; FERNANDES, 2002).

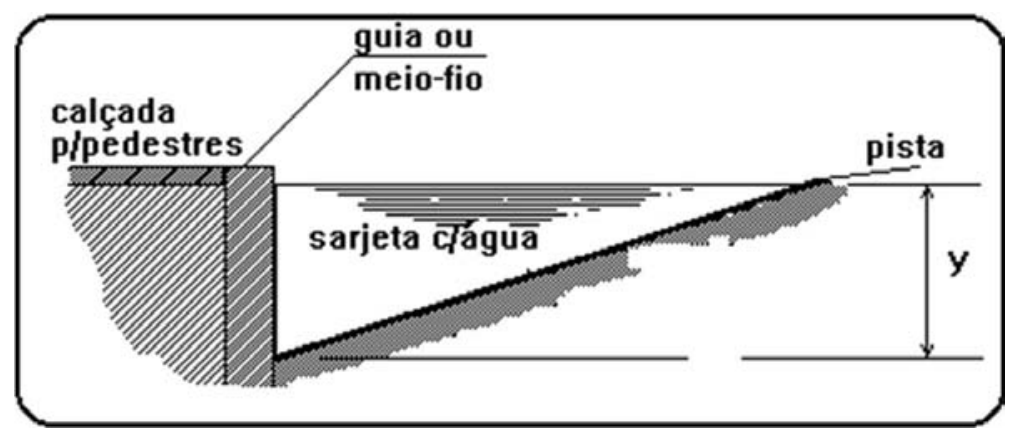

Figura 35: Esquema de uma sarjeta (FERNANDES, 2002). 
- Sarjetões: consistem em calhas localizadas nos cruzamentos de vias públicas, normalmente de seção triangular, formadas pela sua própria pavimentação e destinadas a orientar o fluxo das águas que escoam pelas sarjetas ou encaminhar efluentes destas para pontos de coleta (BIDONE e TUCCI, 1995; FERNANDES, 2002).

- Condutos forçados: são obras que atuam na condução das águas superficiais coletadas de maneira segura e eficiente, e sem preencher toda a seção transversal do conduto (BIDONE e TUCCI, 1995).

- Estações de bombeamento: compreende o conjunto de obras e equipamentos que retiram água de um canal de drenagem, quando não há condição de escoamento por gravidade, para outro canal em nível mais elevado ou receptor final (BIDONE e TUCCI, 1995).

O projeto do sistema de microdrenagem de uma cidade deve levar algumas considerações em questão. Este deve ser composto por três conjuntos de cálculos, o da capacidade admissível das sarjetas, das bocas de lobo e do sistema de galerias pluviais. Para isto, são empregados simultaneamente conceitos e formulações de processos hidrológicos, para a estimativa de vazões de projeto, e relativos ao escoamento em superfície livre, para o projeto hidráulico dos condutos (POMPÊO, 2001).

Deve-se então realizar um traçado da rede pluvial, em planta com escala de detalhe (1:2000 ou 1:1000), seguindo-se algumas regras básicas. Os divisores de bacia e as áreas de contribuição devem ser assinalados nas plantas; os trechos de escoamento apenas por sarjetas devem ser indicados por setas; as galerias pluviais devem ser lançadas sob os passeios, sempre que possível; o sistema coletor de uma via poderá ser uma rede única; e as soluções mais adequadas, para cada rua, são aquelas adequadas economicamente à sua largura e condições de pavimentação (BIDONE e TUCCI. 1995).

Para dar prosseguimento ao escoamento superficial proveniente das ruas, sarjetas, valas e galerias, ou seja, das estruturas de microdrenagem, são empregadas as estruturas de macrodrenagem, cuja função é conduzir essas águas a um destino final. A macrodrenagem de uma área urbana consiste na rede de drenagem natural, pré-existente nos terrenos antes da ocupação, ou seja, correspondem aos córregos, riachos e rios localizados nos talvegues e vales (MARTINS, 1995).

Muitos dos problemas erosivos urbanos estão relacionados com o lançamento das águas dos emissários no terreno natural. Mesmo em casos em que são construídos dissipadores de energia, dependendo da declividade do terreno, e da resistência do solo, o volume de água pode dar início ao processo erosivo, a jusante do lançamento, de forma acelerada, levando à 
destruição do dissipador e do próprio emissário (GALERANI et al, 1995). Para evitar esse tipo de problema podem ser utilizadas uma série de estruturas de macrodrenagem, como as indicadas a seguir.

- Canais: são estruturas que podem ser construídas em concreto armado, alvenaria, gabiões, ou simplesmente escavados no terreno e protegidos com cobertura vegetal (DAEE, 1990). Em muitos casos são necessárias obras e projetos de retificação e ampliação das seções dos canais naturais, ou a construção de canais artificiais ou galerias de grandes dimensões. Essa estrutura, porém, apresenta uma particularidade, o escoamento nela é hidrodinâmico, ou seja, varia no tempo e no espaço em função de eventos hidrológicos e de peculiaridades no traçado. Há ainda os canais fechados, que são mais completos, pois o escoamento pode deixar de ser livre para ser forçado, de acordo com a variação das condições (MARTINS, 1995).

- Emissário: compreende o coletor que recebe a água dos coletores principais de toda a bacia. No caso de áreas urbanas os emissários ocorrem sob a forma de tubos com diâmetros comerciais, quando o volume de água admite; na forma de galerias subterrâneas de formas diversas; ou de canais abertos (GALERANI et al, 1995).

- Dissipadores de energia: estas estruturas são dispostas na saída dos emissários, com a finalidade de reduzir a velocidade das águas, permitindo um fluxo tranquilo no talvegue receptor. A dissipação da energia hídrica se dá pela introdução do jato d'água a um choque com um defletor vertical, ou através da formação de ressalto hidráulico. Existem vários tipos de dissipadores de energia, sendo os principais o BP (Bradley Peterka), o MS (Munir Saab), a bacia de imersão e os dissipadores de ressalto hidráulico (GALERANI et al, 1995).

- Vertedores: essas estruturas são construídas em locais de barramento da água escoada, tendo como objetivo conduzir a água em excesso controladamente. Os tipos mais comuns de vertedores são: o de queda e o vertedor em tubulação (cachimbo ou tulipa). Os vertedores devem ser associados à obras de dissipação de energia, como bacias, degraus hidráulicos, chicanas, entre outros (DAEE, 1990).

- Espigões: São obras que visam à estabilização de fundo, contendo o alargamento do talvegue, que foi transformado em canal. Os espigões contribuem para a deposição de material nas margens do canal, protegendo-as. Estruturalmente, consistem em paramentos executados junto às margens dos rios, afastando-se das mesmas em diagonal ao sentido do escoamento. A deposição de sedimentos desses paramentos contribui para a criação de um 
vórtice, e consequentemente, para a redução de velocidade do escoamento, estreitando assim a seção do canal (GALERANI et al, 1995).

- Barragem de assoreamento: esse tipo de barragem leva a diminuição da velocidade da água e a uma maior decantação de sólidos suspensos, ocasionando na diminuição da declividade do fundo do talvegue. Existem vários tipos de barragens, cuja construção varia em complexidade de acordo com a altura. Estas podem ser construídas em terra, pedras, gabião, concreto e concreto armado (GALERANI et al, 1995). Essa estrutura é bastante utilizada no interior de voçorocas que apresentam escoamento de fundo, podendo, nesse caso, ser construídas com terra, madeira, sacos de solo-cimento, gabião e concreto (DAEE, 1990).

- Bacia de acumulação: as águas provenientes de emissários devem ser conduzidas a locais de maior estabilidade, para evitar a erosão; Em situações que esses locais encontram-se distantes, pode-se optar pela utilização de um reservatório de acumulação, com emissário reduzido, que recebe as águas da drenagem urbana e então conduz a água acumulada até um local conveniente (GALERANI et al, 1995).

- Drenos enterrados: em certas situações, como em voçorocas, o lençol freático é suspenso, formando um canal com escoamento superficial, ou subsuperficial. Nesses casos, para evitar o agravamento do processo erosivo, e buscando a recuperação desse tipo de feição, são aplicados drenos enterrados. Os tipos mais comumente empregados em voçorocas são: o dreno cego (Figura 36), composto por uma valeta revestida com material filtrante e por um seguimento de tudo perfurado, disposto na saída do dreno; e sobre o material filtrante instala-se material impermeável, constituído por argila ou plástico. O dreno com geotextil (Figura 37) compreende um revestimento de uma vala, com manta geotextil de preenchimento, que envolve totalmente o material filtrante de enchimento, funcionando como um selo. E ainda, o dreno de bambu (Figura38) é executado com bambus amarrados em feixes, assentados na vala e envolvidos com brita ou geotextil, fechando a vala com material impermeável (DAEE, 1990).

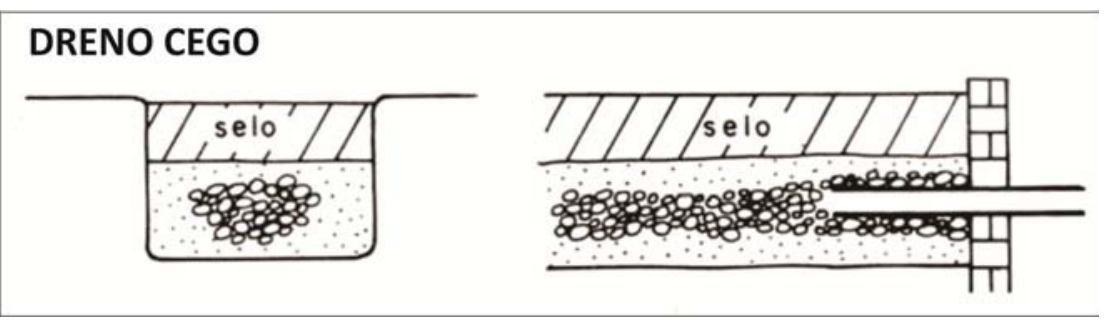

Figura 36: Dreno de fundo, ou enterrado, do tipo cedo (DAEE, 1990). 


\section{DRENO DE GEOTEXTIL}

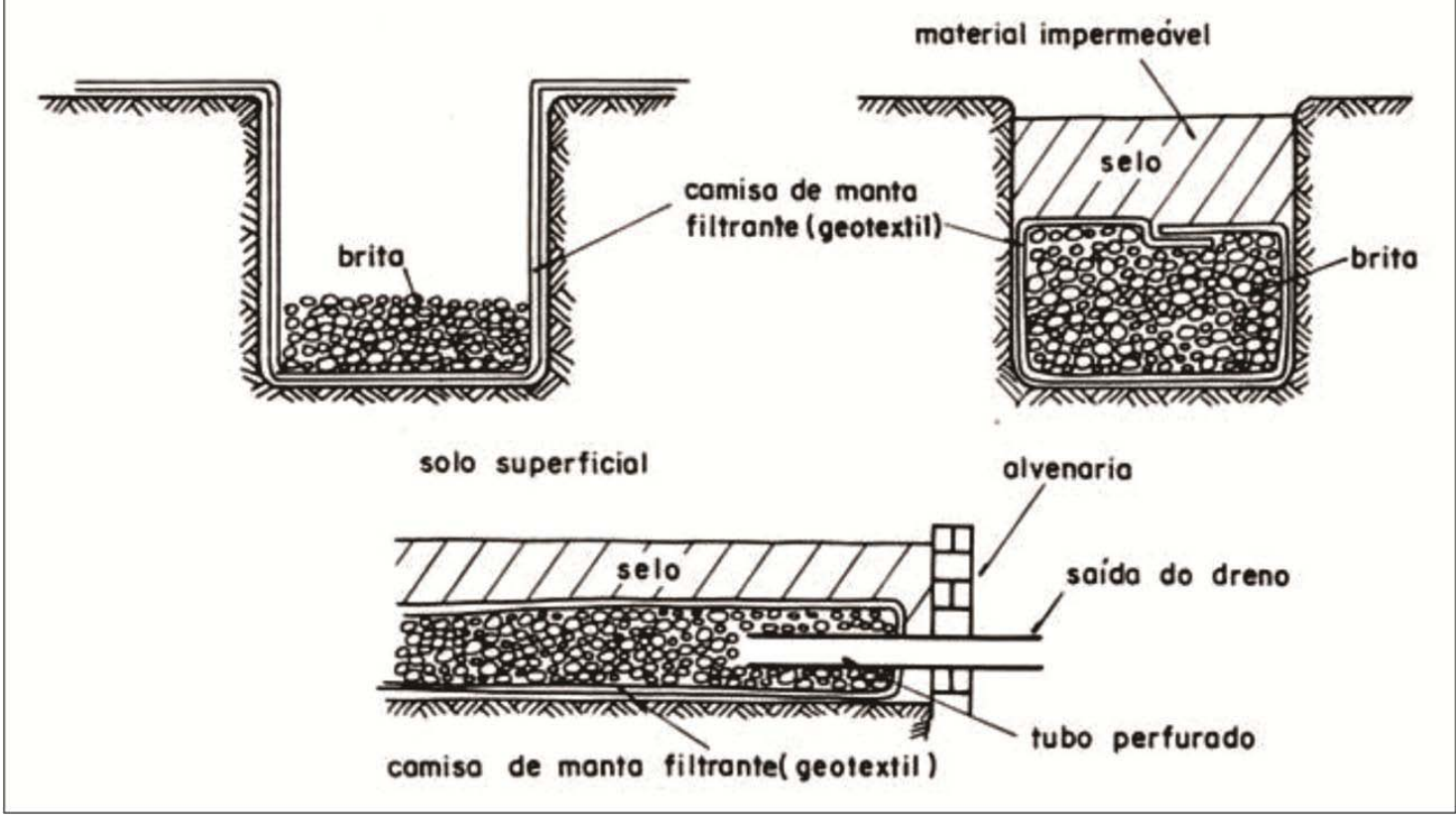

Figura 37: Dreno de fundo, ou enterrado, de geotextil (DAEE, 1990).

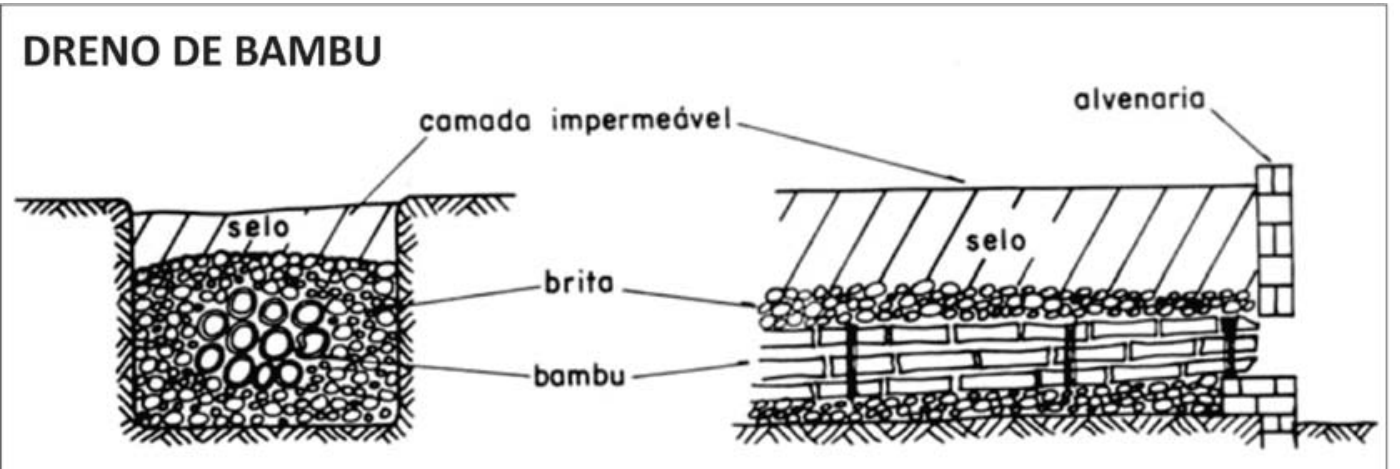

Figura 38: Dreno de fundo, ou enterrado de bambu (DAEE, 1990). 


\section{MATERIAIS E MÉTODOS}

O desenvolvimento desse trabalho envolveu uma série de etapas, que compreenderam tanto trabalhos de escritório, quanto de campo, que posteriormente serviram de base para a avaliação final. Essas etapas estão sumarizadas no fluxograma da Figura 39.

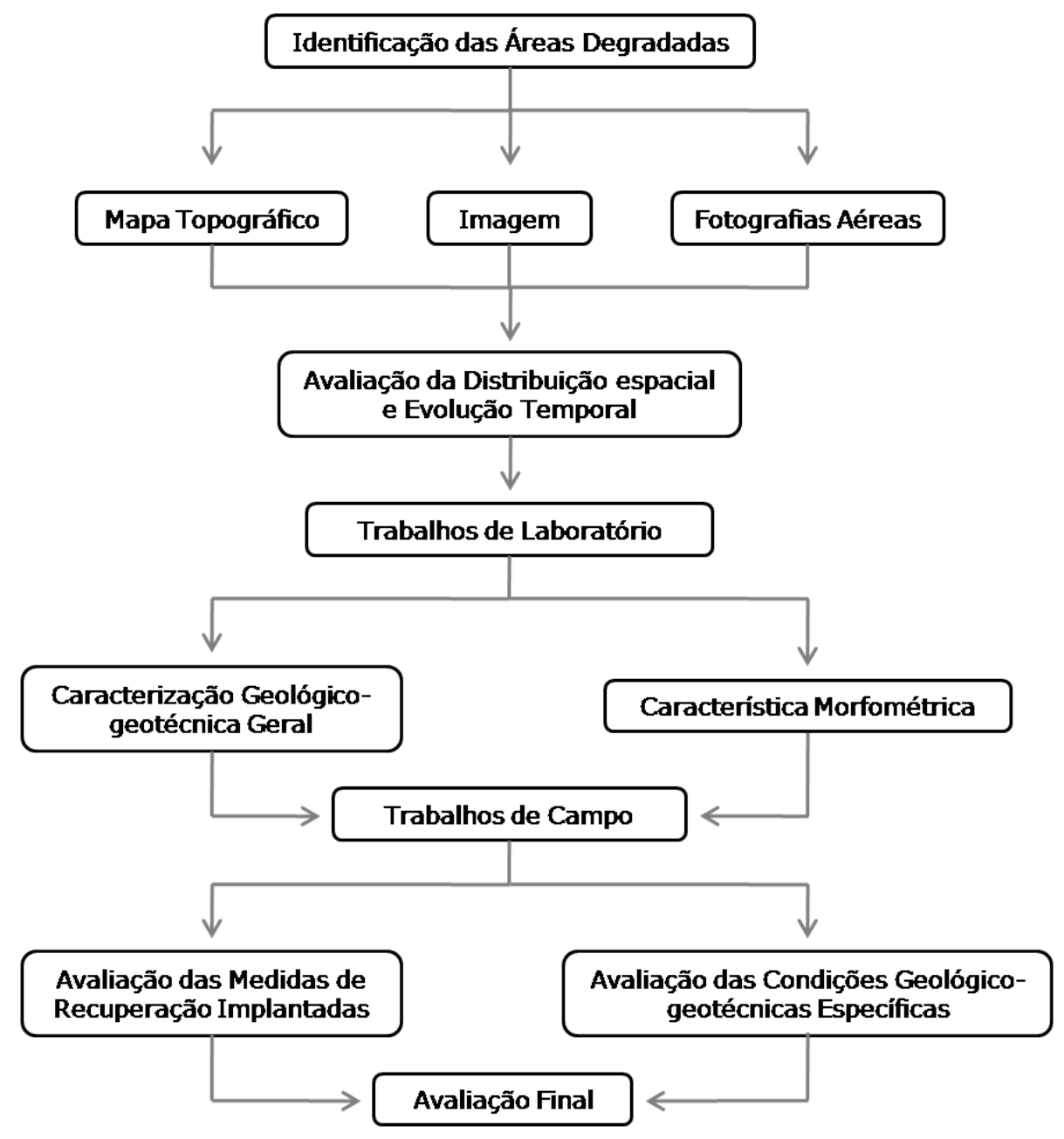

Figura 39: Fluxograma indicando as principais etapas do trabalho.

\subsection{Trabalhos de escritório}

A primeira etapa compreendeu a identificação de diferentes áreas degradadas por processos erosivos em que foram adotadas medidas de prevenção, controle, mitigação ou recuperação da erosão; e que são o objeto de estudo desse trabalho. Após a identificação 
dessas áreas, foram reunidos materiais cartográficos que as abrangessem, como mapas topográficos nas escalas de 1:10000, imagens de satélite, e fotografias aéreas dos anos de 1972, 1978, 1995, 2000, 2006, 2011. Além da obtenção desses materiais, foi realizado levantamento bibliográfico, tanto de trabalhos anteriores realizados nos locais de estudo, quanto de bibliografias relacionadas à temática erosiva, sobretudo quanto às técnicas de recuperação.

Em um segundo passo, com o auxílio dos materiais cartográficos, e do software AutoCAD Map 2009, os mapas topográficos foram digitalizados e as áreas de estudo, que compreendem bacias hidrográficas, foram delimitadas. A base topográfica digital foi ainda utilizada para gerar superfícies representativas das diferentes áreas, com o auxílio do software Surfer 8, nas quais foram localizadas as principais feições erosivas atualmente existentes, cujas coordenadas foram obtidas em campo, com o auxílio de GPS.

As fotografias aéreas e as imagens de satélite, por sua vez, foram empregadas na avaliação temporal da dinâmica do uso e ocupação do solo, do processo erosivo, e das medidas de recuperação, para cada área. A partir desses materiais, baseando-se também nas informações encontradas nos trabalhos anteriores, foi realizada a caracterização geológicogeotécnica dos materiais geológicos, considerando-se aspectos como distribuição espacial, tipos e texturas; e também foram identificados os aspectos geomorfológicos de cada área.

\subsection{Trabalhos de campo}

Após as etapas de escritório deu-se início aos trabalhos de campo, que apresentavam dois objetivos principais. O primeiro objetivo relaciona-se à realização de uma caracterização geológico-geotécnica em termos de propriedades relacionadas à erodibilidade e as morfométricas específicas de cada área, e de cada feição; complementando-se assim as informações obtidas nos trabalhos anteriores. O segundo objetivo das atividades de campo, por sua vez, era o de identificar as medidas de recuperação existentes nas áreas estudadas, e em seguida, realizar uma avaliação prévia de sua eficiência e adequabilidade.

Para a realização dessa etapa foi desenvolvida uma ficha de campo, cujo preenchimento tem o intuito de orientar, tanto a obtenção das principais informações sobre o meio físico e sobre as medidas de recuperação, quanto direcionar as análises prévias dessas informações. As fichas abordavam oito tópicos principais, que compreendem: informações iniciais sobre a área; caracterização da erosão; materiais geológicos; vegetação; uso da área; águas; medidas de 
recuperação adotadas; e características do relevo. Um exemplar da ficha de campo está representado pelo Anexo 1 desse trabalho.

\subsection{Avaliação final}

A partir de todas as informações, obtidas tanto nas etapas de escritório quanto de campo, foi realizada uma análise com o objetivo de avaliar o sucesso ou o fracasso de cada medida de recuperação adotada, assim como o grau de adequação ao problema.

Inicialmente, considerou-se, sob uma ótica geral, que uma medida, ou o conjunto de medidas, adotada em uma área, alcança a eficiência no momento em que não se verifica a progressão, reativação, ou surgimento de feições erosivas; e quando as taxas de sedimentos gerados pela região são estabilizadas ou reduzidas. Com base nesse pressuposto, cada cenário foi avaliado a partir da identificação de uma série de aspectos, indicados a seguir.

1) Relativo à presença de feições erosivas:

- Foram identificadas as feições existentes;

- Foi avaliado se essas feições estavam ativas ou estáveis;

- Foi verificado se havia possibilidade de reativação das feições estáveis;

- E foi identificada a origem do processo erosivo.

2) Quanto ao objetivo pretendido com a aplicação de cada medida foi verificado se ele pretendeu:

- Prevenir;

- Controlar;

- Mitigar;

- Ou recuperar.

3) Em relação à compatibilidade das técnicas adotadas estas foram analisadas:

- Em relação ao cenário erosivo;

- Em relação ao uso e ocupação do local;

- Em relação a si mesmas (se são complementares).

4) Quanto à escolha das medidas, foi avaliado se elas consideraram:

- Os aspectos geológico-geotécnicos dos materiais geológicos;

- Os aspectos geológico-geotécnicos envolvidos no projeto; 
- As condições do meio físico, como o tipo de vegetação, regime de chuvas, e tipo de relevo.

5) Quanto à escolha das medidas foi verificado ainda se esta se baseou em estudos prévios de adequabilidade.

6) Quanto à execução das obras de implantação das medidas verificou-se:

- Se estas seguiram determinações de projeto;

- Se os métodos executivos foram adequados;

- Se as dimensões das estruturas eram adequadas.

7) Relativo aos problemas ocorridos com as diferentes medidas empregadas verificouse:

- Quais tipos de problemas ocorreram;

- A frequência com que os diferentes problemas ocorreram;

- O motivo da ocorrência dos mesmos.

8) Quanto à relação entre o uso desenvolvido após a recuperação e as medidas empregadas, também foi avaliada a sua compatibilidade.

9) Quanto à abrangência das medidas, observou-se:

- Se estas eram pontuais, ou seja, se eram restritas à atuação em problemas específicos;

- Ou se atuavam em toda a área, com diferentes objetivos.

Após a avaliação individual dos aspectos descritos, foi realizada uma análise conjunta das informações, o que permitiu avaliar a eficiência e adequabilidade dos cenários de recuperação. $\mathrm{E}$ finalmente, a partir da identificação dos principais problemas existentes em cada área, foram propostas soluções mais efetivas.

\subsection{Lista de Materiais}

Os materiais utilizados para o desenvolvimento desse trabalho foram:

- Mapas topográficos da região de São Pedro na escala 1:10000;

- Fotografias aéreas, em diferentes escalas, dos anos de 1962, 1972, 1988, 1995, 2000 e 2006;

- Imagem de satélite do ano de 2011;

- Fichas de campo;

- Softwares: AutoCAD Map 2009 e Surfer 8. 


\section{CARACTERIZAÇÃO DA ÁREA DE ESTUDO}

Nesse trabalho foram estudadas 4 áreas, sendo elas bacias hidrográficas pertencentes à cidade de São Pedro - SP, designadas ao longo do trabalho por Área 1, Área 2, Área 3 e Área 4.

Dentre às áreas que pertencem a esse município, a Área 1 corresponde à um loteamento em fase de execução, cujas atividades foram interrompidas, dando lugar à um uso provisório, que compreende a cobertura por pastagens acompanhada da criação de gado. A Área 2, compreende um bairro residencial de São Pedro, bastante ocupado, mas com terrenos vagos. A Área 3, por sua vez, compreende um bairro ocupado em sua maioria por pousadas, apresentando vários lotes desocupados, e ainda ruas sem pavimentação. Por último, a Área 4 corresponde a uma área rural, onde o uso compreende a plantação de eucalipto com finalidade comercial. A Figura 40 mostra a localização das quatro áreas. 


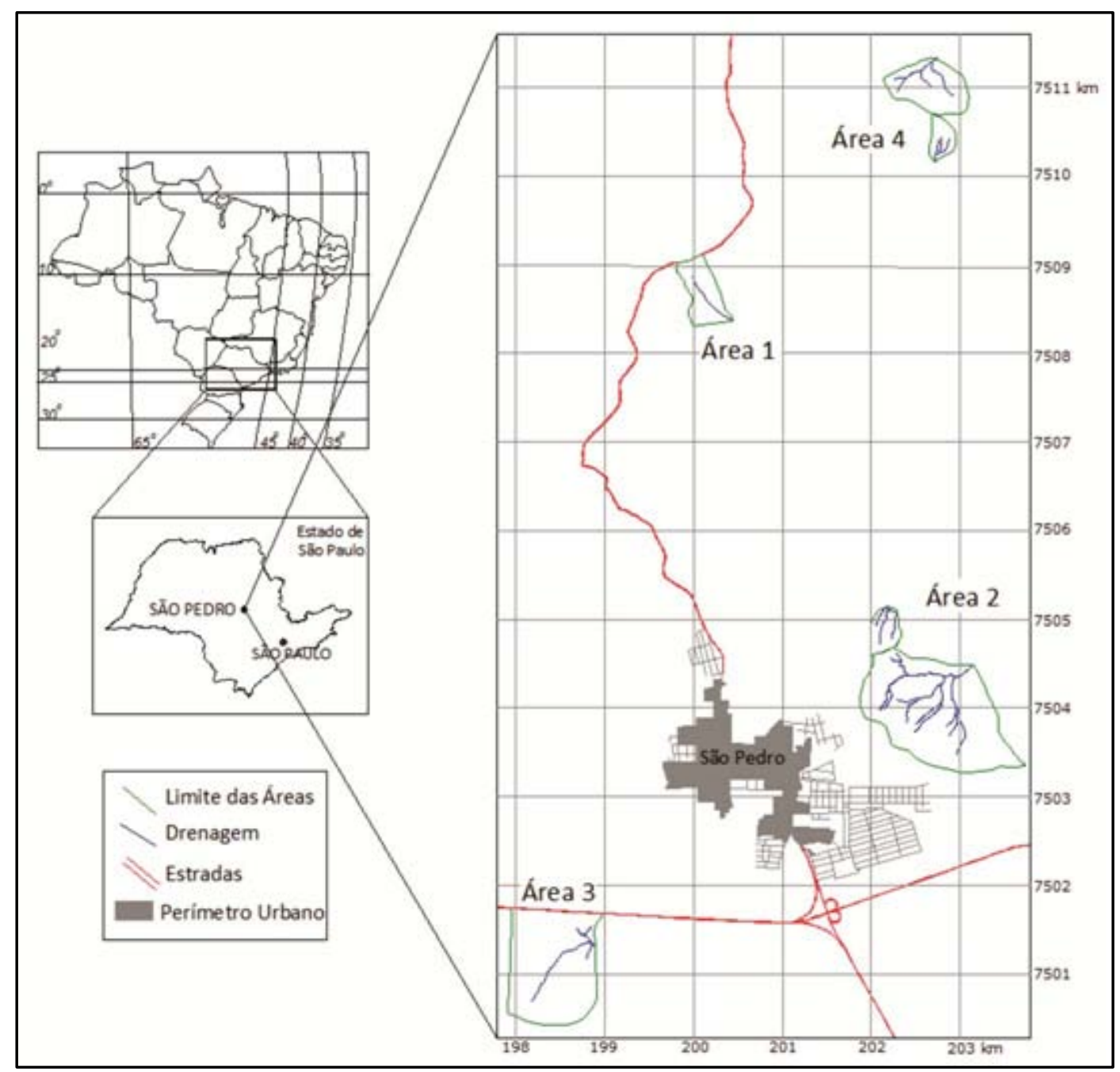

Figura 40: Localização das áreas de estudo pertencentes ao município de São Pedro - SP.

Quanto à geomorfologia, as áreas compreendem partes das zonas geomorfológicas denominadas de Planalto Ocidental, Cuestas Basálticas e Depressão Periférica, com altitudes que variam entre 955 a 505 metros.

O tipo climático da região se enquadra como Cwa, de acordo com a classificação de Koppen (1948), apresentando chuvas totais anuais variando entre 1200 a $2000 \mathrm{~mm}$, com períodos de chuva e de seca bem definidos.

A geologia da região é constituída por rochas pertencentes a quatro formações geológicas: Formação Itaqueri, Formação Serra Geral, Formação Botucatu e Formação Pirambóia. As características principais dessas formações estão representadas na Tabela 3. 
Tabela 3: Características básicas das formações geológicas da região.

\begin{tabular}{|c|c|c|c|}
\hline Formação Geológica & Idade & Litologias & Características Básicas \\
\hline Itaqueri & $\mathrm{K}$ & $\begin{array}{c}\text { Arenitos } \\
\text { Siltitos } \\
\text { Argilitos }\end{array}$ & $\begin{array}{c}\text { Intercalados, com camadas desde } \\
\text { métrica até dezenas de metros }\end{array}$ \\
\hline Serra Geral & J-K & Basaltos & Muito fraturados \\
\hline Botucatu & T-J & Arenitos eólicos & $\begin{array}{c}\text { Arenitos silicificados no topo e } \\
\text { friáveis na base }\end{array}$ \\
\hline Pirambóia & $\mathrm{T}$ & Arenitos Fluviais & $\begin{array}{c}\text { Arenitos com até 25\% de finos } \\
\text { (cimento) }\end{array}$ \\
\hline
\end{tabular}

As litologias apresentadas são recobertas por pacotes de materiais inconsolidados, predominantemente residuais, com espessuras variando entre 0,5 até 20 metros; e com texturas relacionadas ás rochas de origem, predominantemente arenosas ( $>50 \%$ areia).

A Figura 41 representa um perfil geológico da região, onde podem ser observadas as formações geológicas, a distribuição dos diferentes tipos de materiais inconsolidados, as classes geomorfológicas, e a localização das Áreas 1, 2, 3 e 4. 
Zonas Geomorfológicas

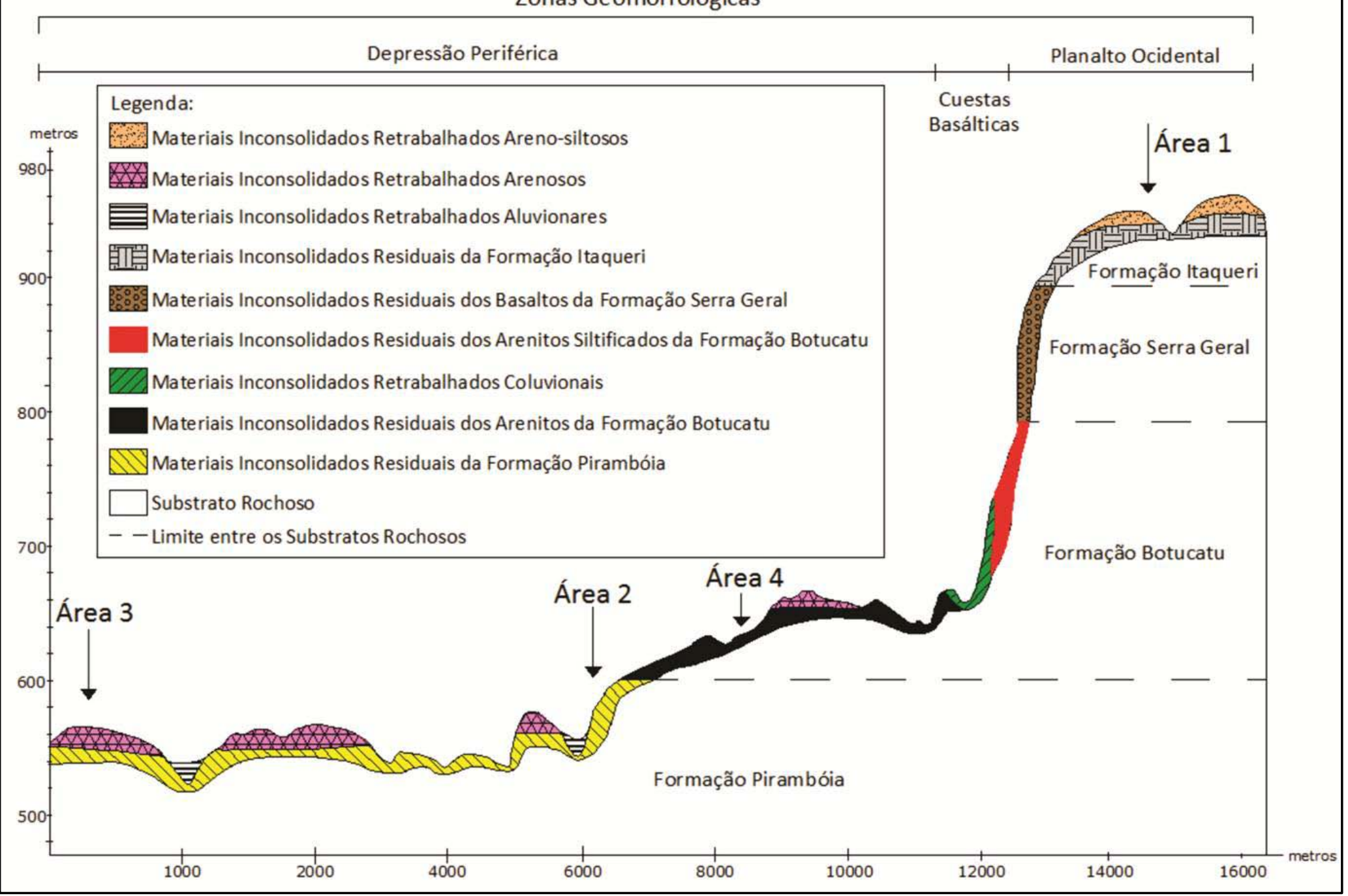

Figura 41: Secção dos materiais geológicos (SE - NW) e das zonas geomorfológicas das Áreas 1,2,3 e 4. 


\section{APRESENTAÇÃO E ANÁLISE DOS RESULTADOS}

\section{1. Área 1}

\subsubsection{Características Básicas}

A Área 1, conforme pode ser observado na Figura 41, localiza-se na zona geomorfológica do Planalto Ocidental, em uma bacia hidrográfica de primeira ordem, com altitudes variando entre 915 e 955 metros.

Quanto aos materiais geológicos, a área está assentada sobre os materiais inconsolidados residuais arenosos, originados de arenitos da Formação Itaqueri, e sobre os retrabalhados areno-siltosos, conforme pode ser observado na Figura 42.

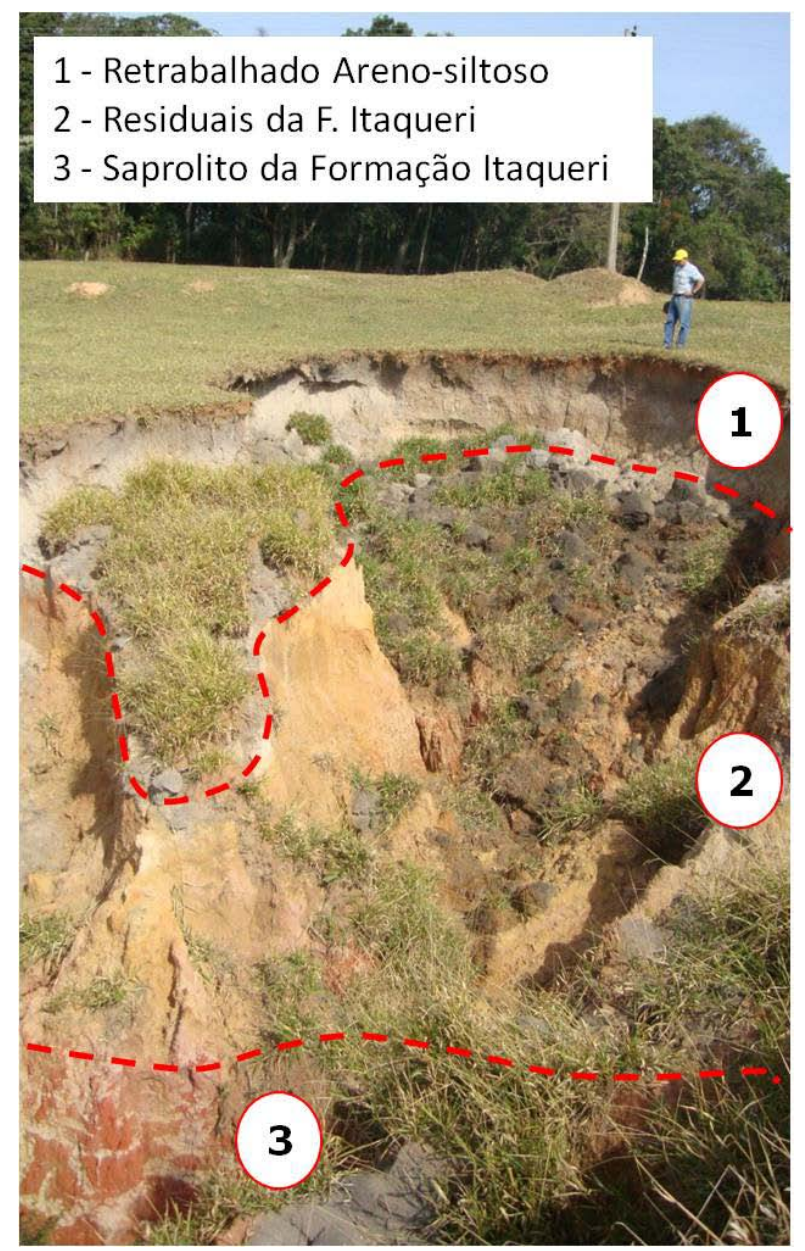

Figura 42: Materiais Geológicos presentes na Área 1. 
Os arenitos residuais da Formação Itaqueri são medianamente cimentados por finos e/ou óxidos e hidróxidos de ferro, e constituídos predominantemente por grãos de quartzo e finos (argila e silte).

Os materiais inconsolidados residuais da Formação Itaqueri ocorrem sotopostos aos arenosos retrabalhados areno-siltosos, com espessuras inferiores a $5 \mathrm{~m}$, e texturalmente são silto-argilosos e arenosos. As texturas estão relacionadas as duas litologias que são predominantes: arenito de topo, ocorrendo nas porções mais elevadas e um siltito-argiloso sotoposto, gerando materiais inconsolidados, e às vezes encontram-se recobertos por retrabalhados. Normalmente, ocorre um pacote bem desenvolvido de cerca de $3 \mathrm{~m}$ de espessura sobre pacotes de saprolitos e rochas alteradas. Estes materiais quando arenosos são bastante erodíveis. Associado encontra-se uma superfície que condiciona fortemente o processo erosivo que é o limite entre a porção mais evoluída e o saprolito.

Por sua vez, os materiais inconsolidados retrabalhados areno-siltosos, foram caracterizados química e fisicamente por Fernandes (2003), através da realização de vários ensaios. Os resultados obtidos pela autora estão representados na Tabela 4, e de maneira geral indicam que esse material apresenta massa específica dos sólidos $p_{s}$ ) igual a $2,67 \mathrm{~g} / \mathrm{cm}^{3}$; com predomínio da fração de areia, mas com uma pequena contribuição de material argiloso.

Tabela 4: Caracterização química e física dos materiais inconsolidados retrabalhados areno-siltosos (FERNANDES, 2003).

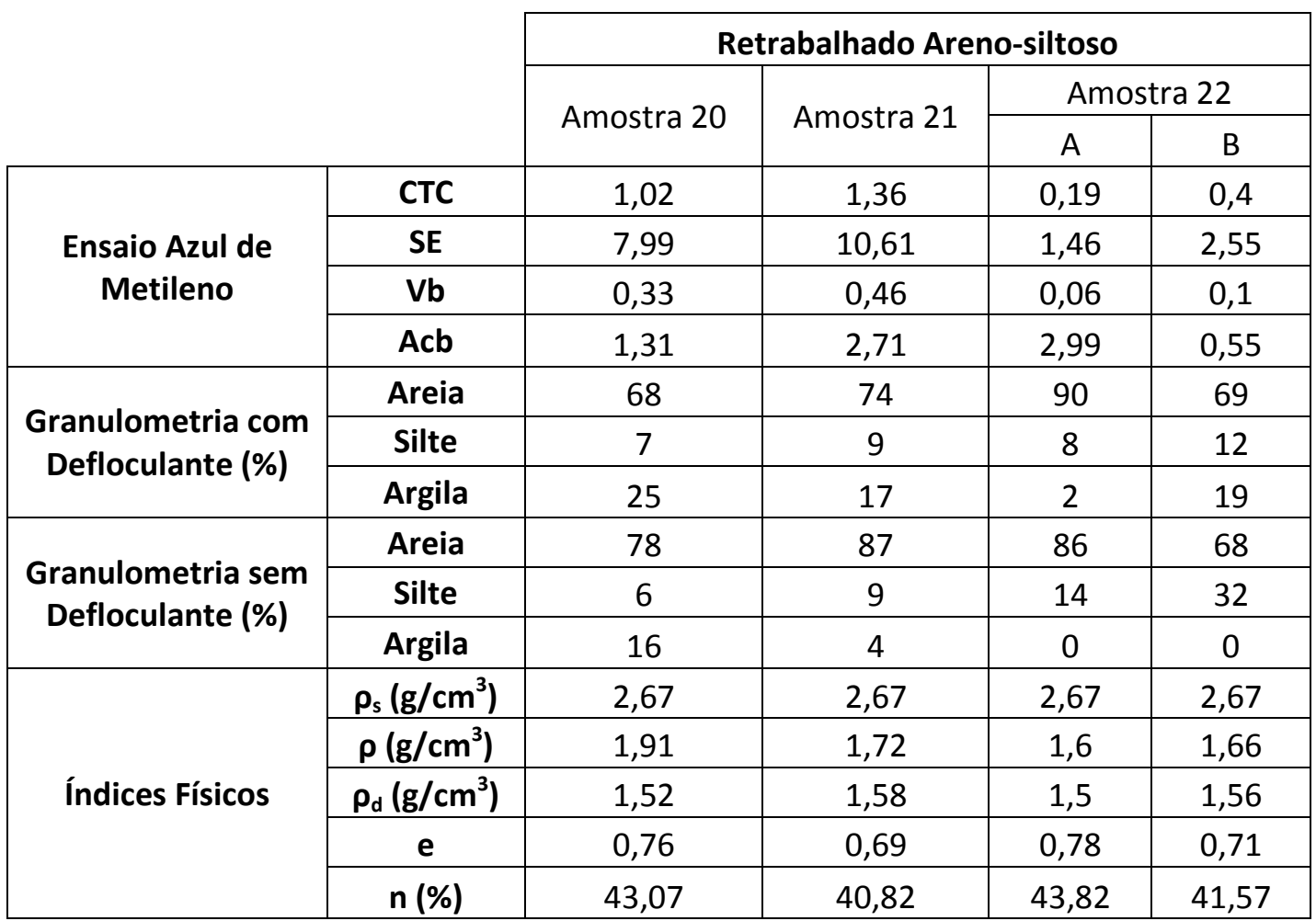


Fernandes (2003) realizou também ensaios de absorção de água e de perda de massa, em amostras com diferentes graus de desenvolvimento, possibilitando o cálculo da erodibilidade para esse material, tanto pelo método de Pejon (1992), quanto pelo método de Nogami \& Villibor (1979), cujos resultados se encontram na Tabela 5, indicando, de um modo geral, baixa erodibilidade do material.

Tabela 5: Erodibilidade dos materiais inconsolidados retrabalhados areno-siltosos, obtidos pelos métodos de PEJON (1992), e de NOGAMI e VILLIBOR (1979) (FERNANDES, 2003).

\begin{tabular}{|c|c|c|}
\cline { 2 - 3 } \multicolumn{1}{c|}{} & \multicolumn{2}{c|}{ Retrabalhado Arenoso de Serra } \\
\cline { 2 - 3 } \multicolumn{1}{c|}{} & $\begin{array}{c}\text { Erodibilidade - } \\
\text { PEJON (1992) }\end{array}$ & $\begin{array}{c}\text { Erodibilidade - NOGAMI } \\
\text { e VILLIBOR (1979) }\end{array}$ \\
\hline Amostra 21A & 2,25 & 2,93 \\
\hline Amostra 21B & 2,52 & 3,28 \\
\hline Amostra 22A & 31,17 & 40,53 \\
\hline Amostra 22B & 6,18 & 8,03 \\
\hline Amostra 22C & 4,79 & 6,23 \\
\hline Amostra 22D & 5,87 & 7,63 \\
\hline
\end{tabular}

\subsubsection{Características do processo erosivo}

O processo erosivo na Área 1 teve início com a mudança da cobertura vegetal, que deixou de ser nativa para dar lugar às pastagens. Porém o processo foi acelerado devido à tentativa de implantação de um loteamento no local, que envolveu a construção de itens de infraestrutura como ruas, rede de energia, obras pluviais e de abastecimento. Contudo, essa atividade foi interrompida por questões legais, dando lugar a um uso provisório, que retomou a criação de gado, com cobertura do solo por pastagens, porém, sem a retirada da infraestrutura urbana. Como resultado dessa prática, as obras de infraestrutura, sobretudo os traçados das ruas e as obras pluviais, favoreceram a ação erosiva da água, o que levou os proprietários a adotarem medidas de controle e recuperação da erosão.

As principais feições erosivas observadas nessa área ocorrem próximas à drenagem, ao longo das duas margens, num total de 15 feições, englobando tanto voçorocas contínuas e perpendiculares em relação ao canal de drenagem, quanto ravinas, igualmente posicionadas. As dimensões e o grau de atividade dessas feições se intensificam quanto mais próximas à nascente. Na Figura 43 tem-se uma superfície representativa da Área 1, gerada no Surfer pelo 
método de interpolação denominado Mínima Curvatura. Nesta está indicada a localização das principais feições erosivas. E em sequência, na Tabela 6 podem-se observar as principais características geométricas dessas feições, e aspectos relacionados à sua estabilidade. 


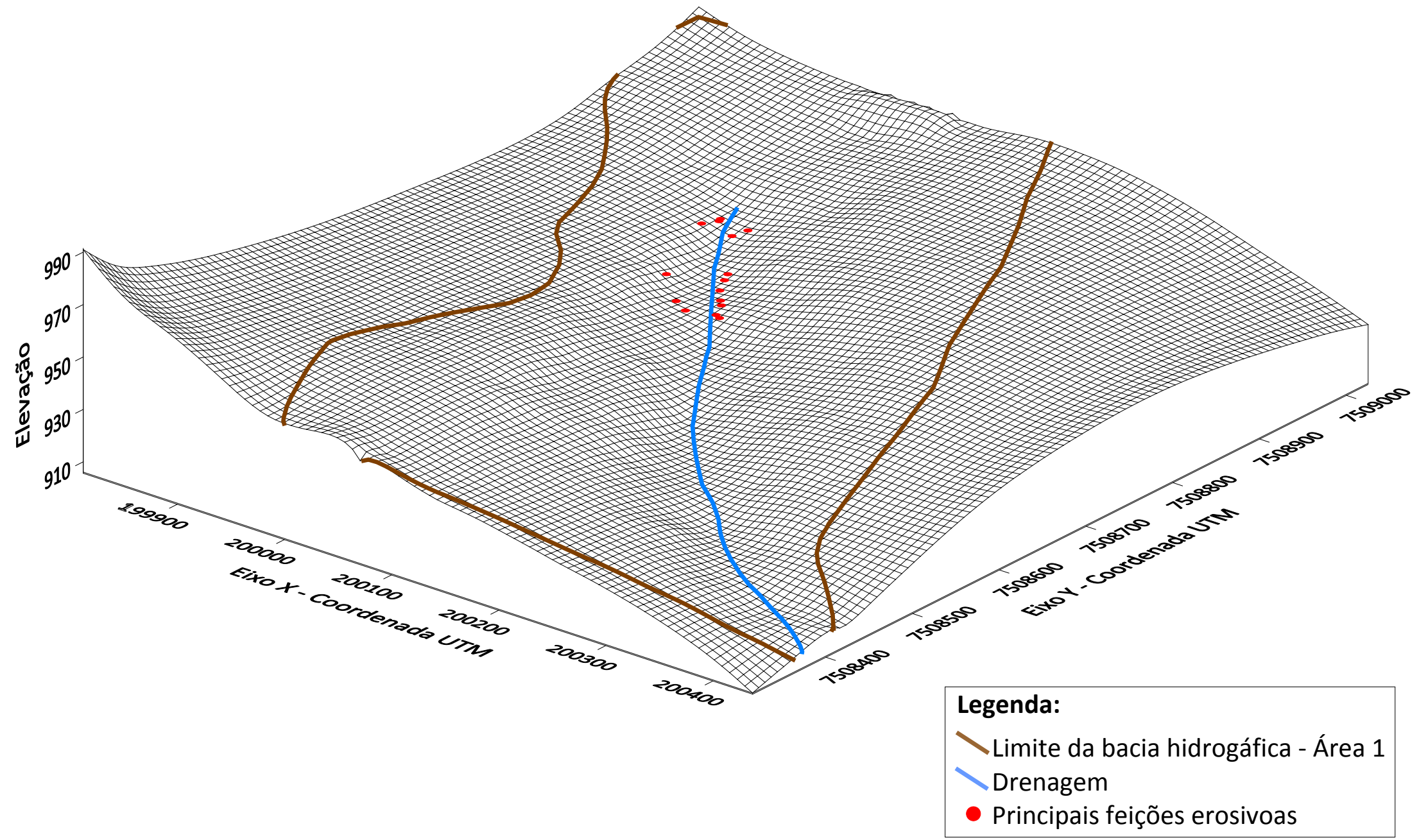

Figura 43: Superfície 3D representativa da Área 1, com localização das principais feições erosivas. 
Tabela 6: Caracterização das principais feições erosivas da Área 1.

\begin{tabular}{|c|c|c|c|c|}
\hline Feição & \begin{tabular}{|c|} 
Comprimento \\
médio $(\mathrm{m})$
\end{tabular} & $\begin{array}{l}\text { Largura } \\
\text { média }(\mathrm{m})\end{array}$ & \begin{tabular}{|c|} 
Profundidade \\
média $(\mathrm{m})$
\end{tabular} & Caracterização \\
\hline F 1 & 5 & 2 & 4 & $\begin{array}{l}\text { Processo erosivo ativo, com } \\
\text { afloramento do lençol, e cabeceira e } \\
\text { paredes bastante íngremes. }\end{array}$ \\
\hline F 2 & 4 a 5 & 3 a 5 & 4 & $\begin{array}{l}\text { Processo erosivo ativo, apresentando } \\
\text { cabeceira e paredes bastante íngremes. }\end{array}$ \\
\hline F 3 & 15 & 10 a 15 & 4 a 5 & $\begin{array}{l}\text { Processo erosivo ativo, com } \\
\text { afloramento do lençol, e cabeceira e } \\
\text { paredes bastante íngremes. }\end{array}$ \\
\hline F 4 & 30 & 4 a 10 & 6 a 15 & $\begin{array}{l}\text { Processo erosivo ativo, com } \\
\text { afloramento do lençol. }\end{array}$ \\
\hline F 5 & 20 & 15 & 8 a 10 & $\begin{array}{l}\text { Processo erosivo ativo, apresentando } \\
\text { cabeceira e paredes bastante íngremes. }\end{array}$ \\
\hline F 6 & 12 a 15 & 3 a 5 & 3 a 4 & $\begin{array}{l}\text { Processo erosivo ativo, com } \\
\text { afloramento do lençol. }\end{array}$ \\
\hline F 7 & 4 & 0,5 & 0,5 & $\begin{array}{l}\text { Pouco evoluída, mas pode ser ativada } \\
\text { em períodos chuvosos. }\end{array}$ \\
\hline F 8 & 1,5 & 1,5 & 0,5 & $\begin{array}{l}\text { Pouco evoluída, mas pode ser ativada } \\
\text { em períodos chuvosos. }\end{array}$ \\
\hline F 9 & 5 & 0,7 & 0,5 & $\begin{array}{l}\text { Pouco evoluída, mas pode ser ativada } \\
\text { em períodos chuvosos. }\end{array}$ \\
\hline F 10 & 3 a 5 & 15 & 2 & $\begin{array}{l}\text { Pouco evoluída, mas pode ser ativada } \\
\text { em períodos chuvosos. }\end{array}$ \\
\hline F 11 & 3 & 8 & 3 a 4 & $\begin{array}{l}\text { Apresenta certa estabilidade, com } \\
\text { vegetação no interior, mas pode ser } \\
\text { reativada nos períodos chuvosos, dada } \\
\text { sua proximidade com o canal principal. }\end{array}$ \\
\hline F 12 & 3 a 6 & 3 a 6 & 3 & $\begin{array}{c}\text { Apresenta certa estabilidade, com } \\
\text { bastante vegetação no interior, mas } \\
\text { pode ser reativada nos períodos } \\
\text { chuvosos. }\end{array}$ \\
\hline F 13 & 8 & 0,5 a 1 & 0,5 a 1 & $\begin{array}{c}\text { Apresenta certa estabilidade, com } \\
\text { bastante vegetação no interior, mas } \\
\text { pode ser reativada nos períodos } \\
\text { chuvosos. }\end{array}$ \\
\hline F 14 & 2 a 6 & 2 & 2 & $\begin{array}{c}\text { Processo erosivo ativo, com } \\
\text { afloramento do lençol, e cabeceira e } \\
\text { paredes bastante íngremes. }\end{array}$ \\
\hline F 15 & 10 & 5 & 2 a 6 & $\begin{array}{l}\text { Processo erosivo ativo, com } \\
\text { afloramento do lençol, e cabeceira e } \\
\text { paredes bastante íngremes. }\end{array}$ \\
\hline
\end{tabular}


As Figuras 44 e 45 representam as feições de grande porte (voçorocas) F3 e F5, localizadas na margem direita do córrego, próximas à nascente; caracterizadas por elevado grau de atividade do processo erosivo, pela presença de afloramento do lençol freático, e por apresentarem paredes bastante íngremes. Por outro lado, as Figuras 46 e 47 mostram as feições F11 e F14 localizadas na margem esquerda, indicando que o processo erosivo nessa região é menos intenso, com feições de menor porte, porém também ativo.

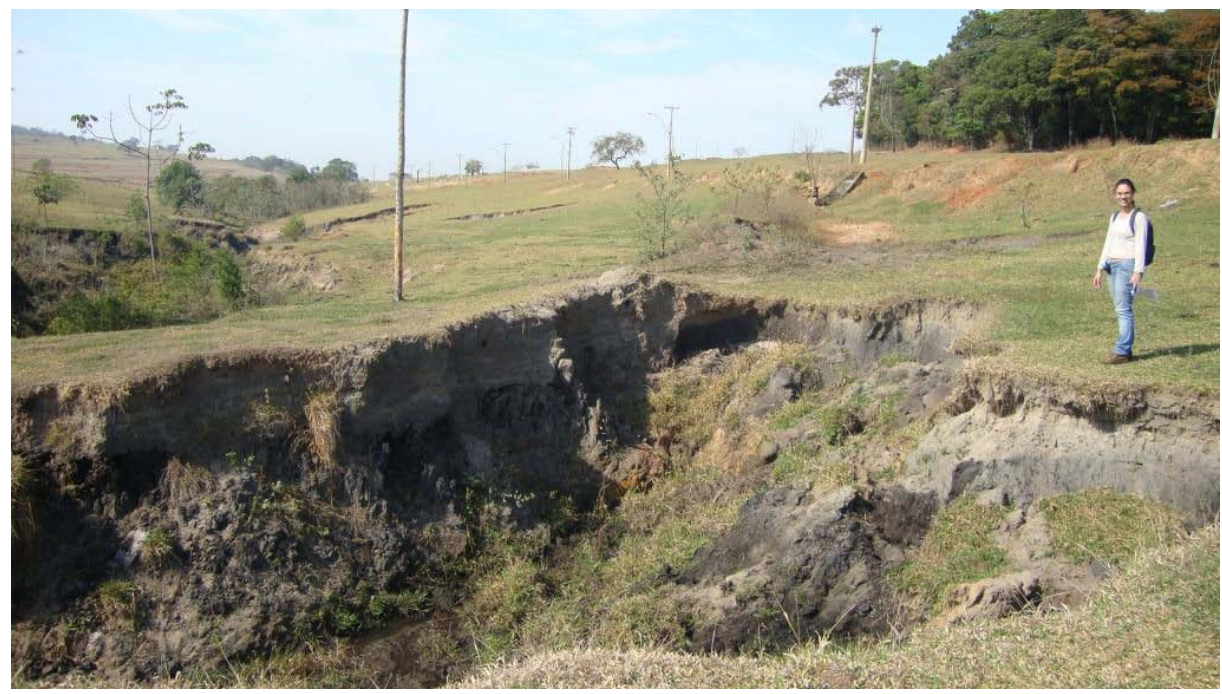

Figura 44: Voçoroca F3, bastante ativa, localizada na margem direita do córrego.

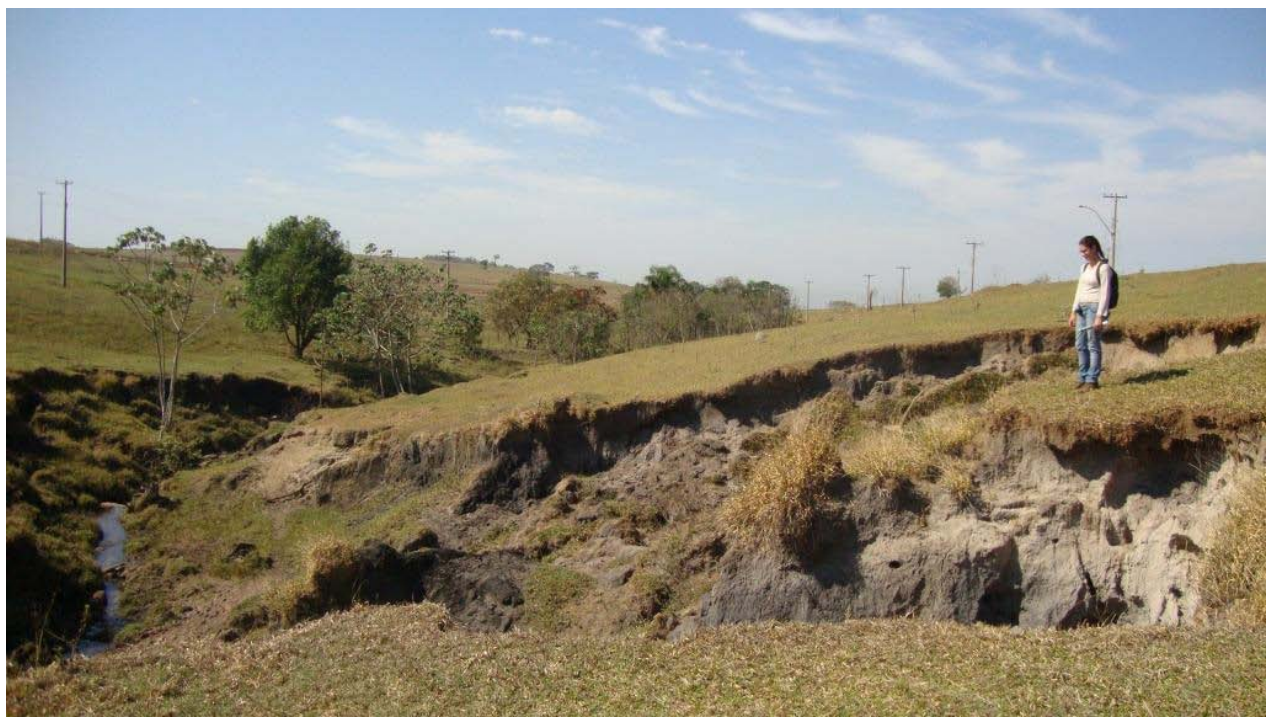

Figura 45: Feição F5, bastante ativa, localizada na margem direita do córrego. 


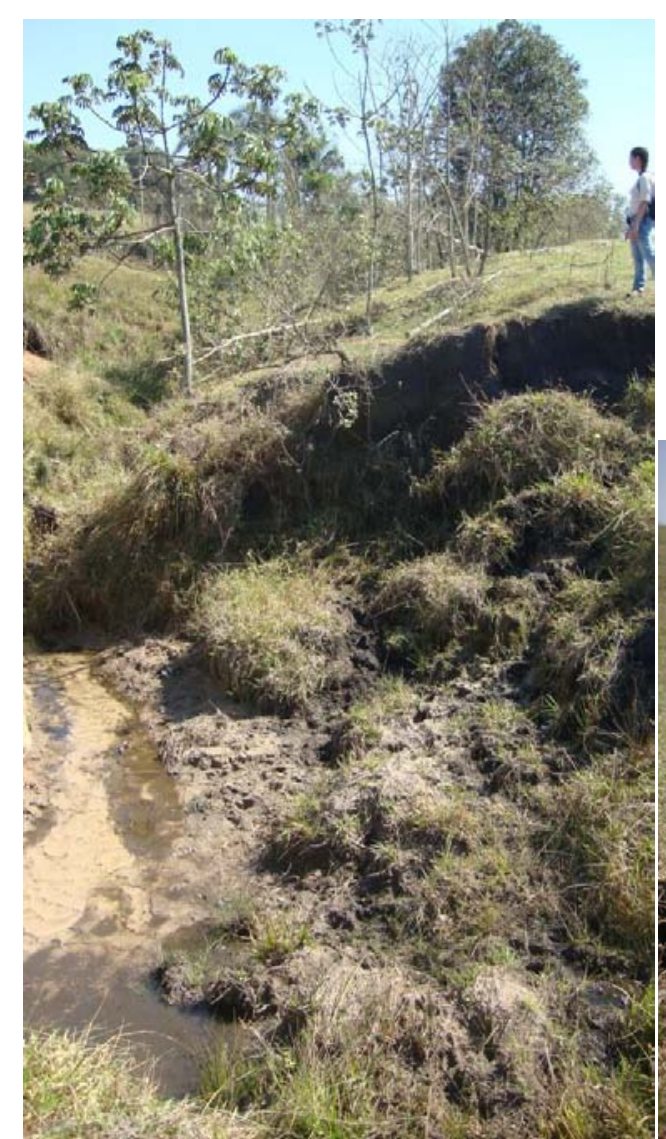

Figura 46: Feição F11, de menor porte, localizada na margem esquerda.

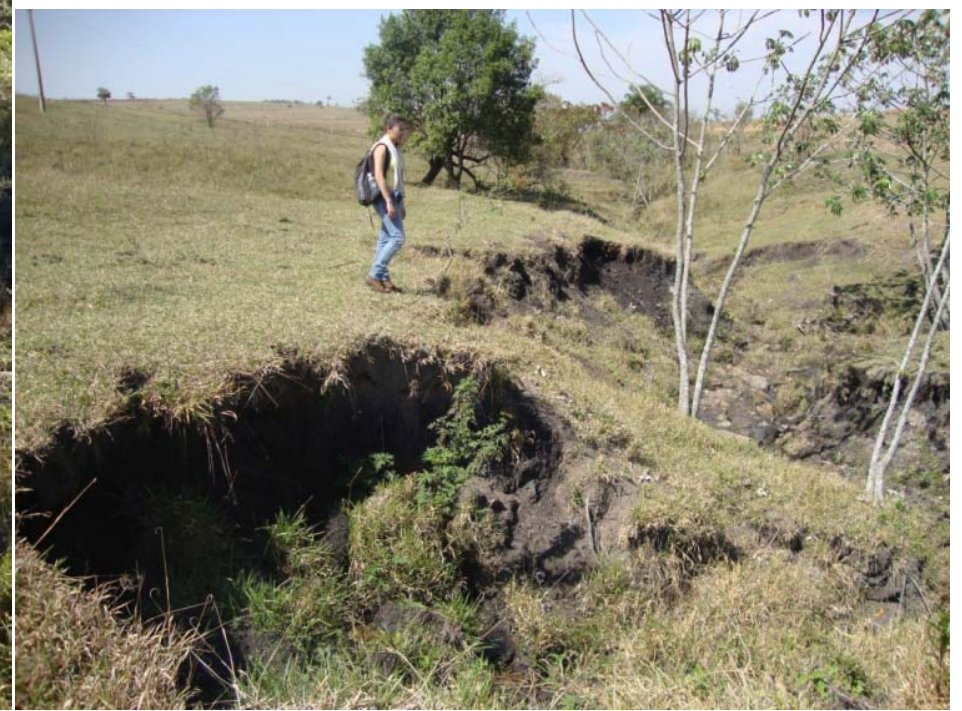

Figura 47: Voçoroca F14, com processo erosivo ativo, que se localizada na margem esquerda, próxima à nascente.

Além das feições erosivas de grande porte, podem ser observados ravinas e sulcos nas encostas e nos traçados de ruas, estando muitas vezes associados a trilhas de gado (Figuras 48 e 49). De um modo geral, observa-se que o processo erosivo nessa área encontra-se ativo, tanto na área atingida por voçorocas, quando nas encostas, onde há predomínio de sulcos e ravinas. 


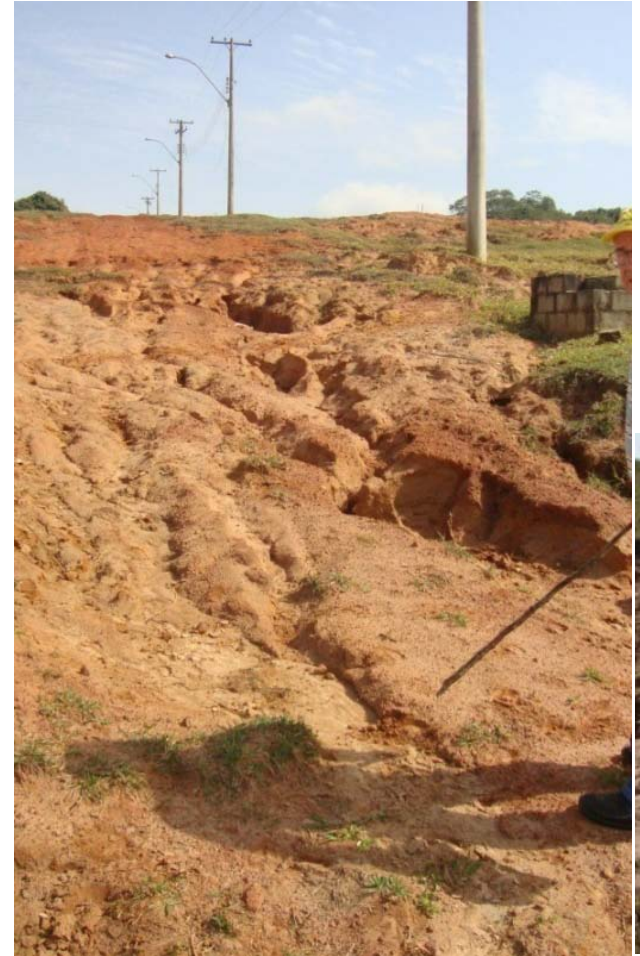

Figura 48: Trecho de uma das ruas do loteamento da Área 1 degradada por sulcos ravinas.

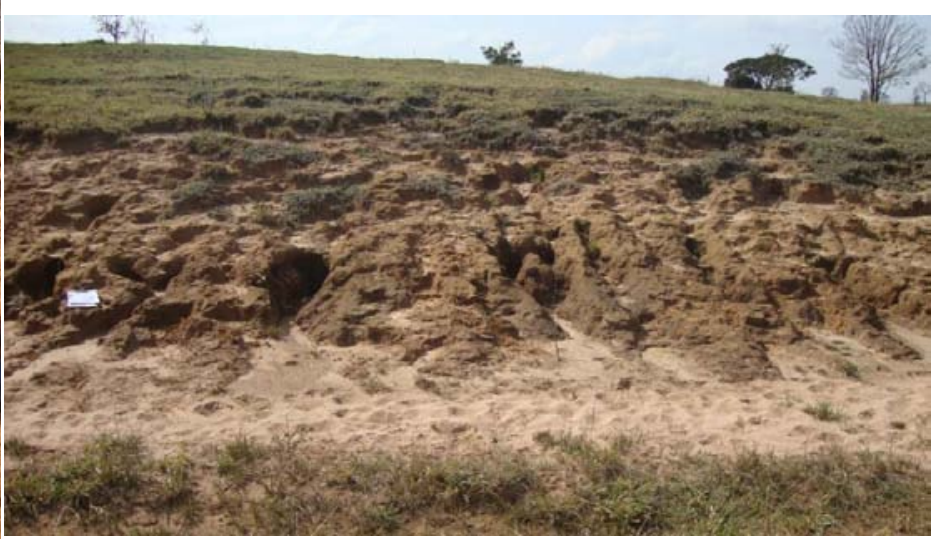

Figura 49: Trecho de uma encosta da Área 1 com a presença de sulcos.

\subsubsection{Descrição das medidas de recuperação.}

Uma das ações adotadas no sentido de controlar os processos erosivos na Área 1 relaciona-se ao próprio uso do solo, e consiste na cobertura com pastagem, como pode ser observado na Figura 50. Essa medida foi empregada em associação à construção de cordões em nível que se estendem por toda área, acompanhando o relevo, e apresentando dimensões iguais a 4 metros de largura, 0,5 metros de altura, e espaçamento entre si variando de 10 a 30 metros. Essa estrutura está apresentada na Figura 51. 


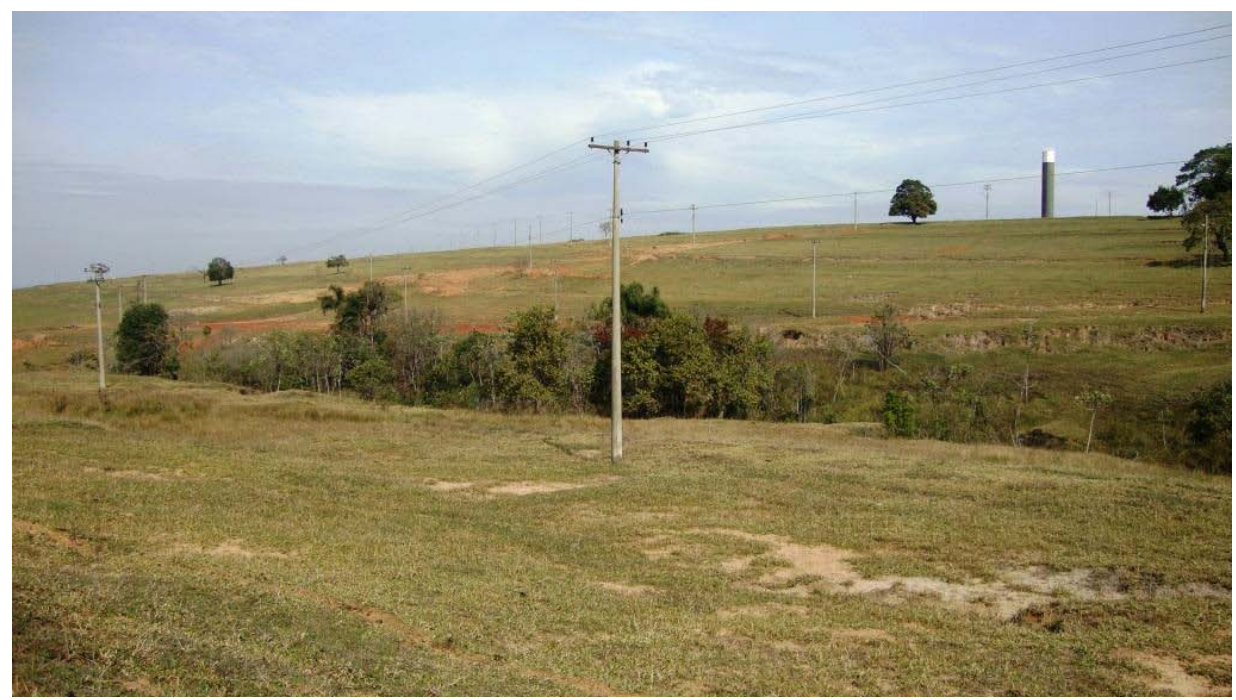

Figura 50: Cobertura do solo com pastagens na Área 1.

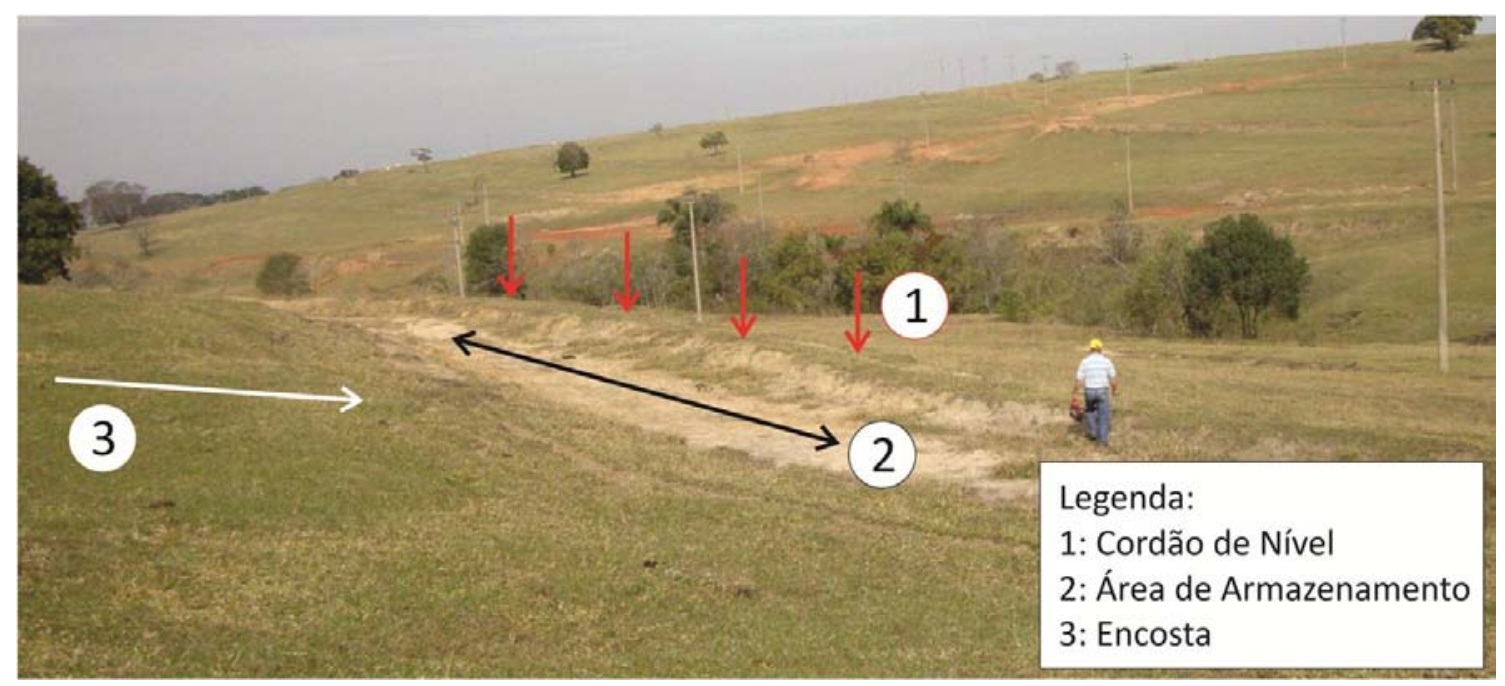

Figura 51: Esquema de um cordão de nível presente nas encostas da Área 1.

Na encosta direita da Área 1, encontra-se a rua principal do loteamento, paralela ao córrego, cujo traçado favorece a concentração do escoamento superficial. Visando evitar que este atinja a área onde estão as grandes feições, o solo foi movimentado e acumulado na borda da rua, principalmente em seu trecho inicial, formando uma espécie de dique ou barreira de proteção, cuja altura é superior ao nível da via (Figura 52). Verificou-se, porém que essa estrutura sofreu ação do processo erosivo. 


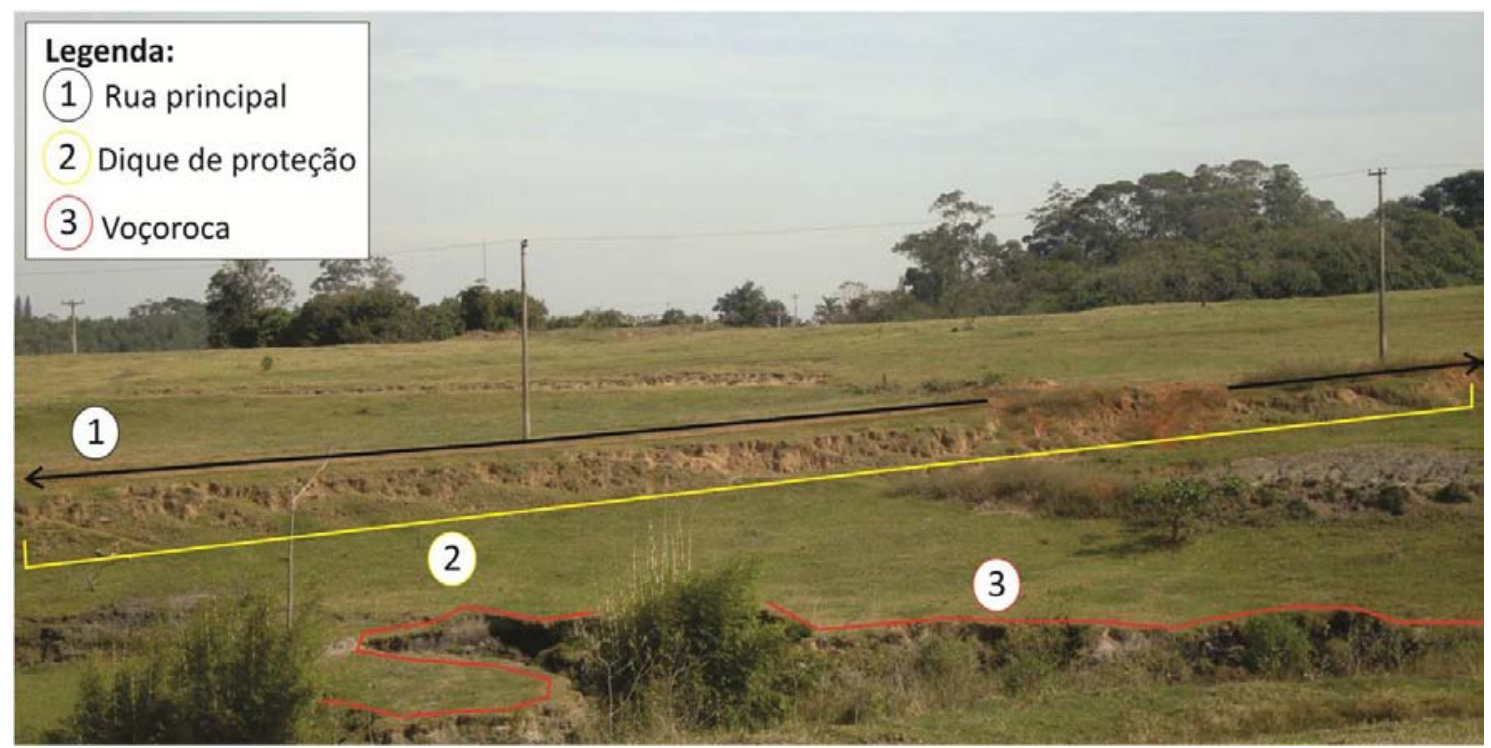

Figura 52: Dique ou barreira de proteção associado à rua principal com o objetivo de diminuir o escoamento superficial que alcança as grandes feições da região.

Além disso, algumas saídas de tubulações, integrantes do sistema de drenagem pluvial, foram dispostas próximas ao canal de drenagem, visando desviar o escoamento de pontos mais elevados das encostas, e proteger as ruas da ação erosiva (Figura 53). Mas a consequência dessa ação foi a concentração do fluxo e aceleração da erosão em pontos específicos próximos ao canal de drenagem. Como solução, diferentes estruturas foram posicionadas nas saídas das tubulações, com o intuito de barrar o escoamento superficial e de aumentar a infiltração. Dentre elas foram utilizados blocos de rochas, muro de contenção e cordão de nível, como podem ser observados nas Figuras 54, 55 e 56. 


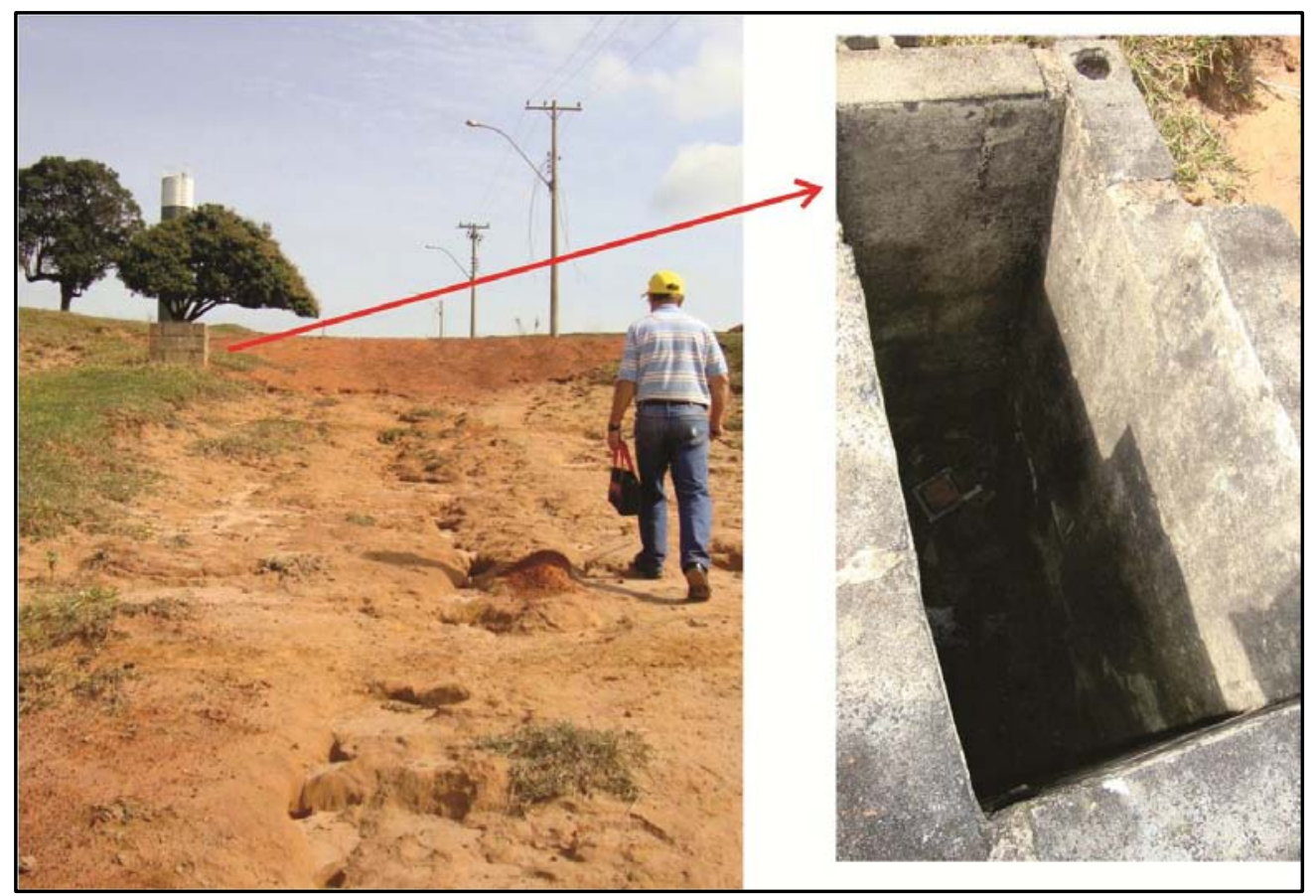

Figura 53: Caixa de Passagem próxima a uma das ruas para redirecionamento da água de escoamento superficial.

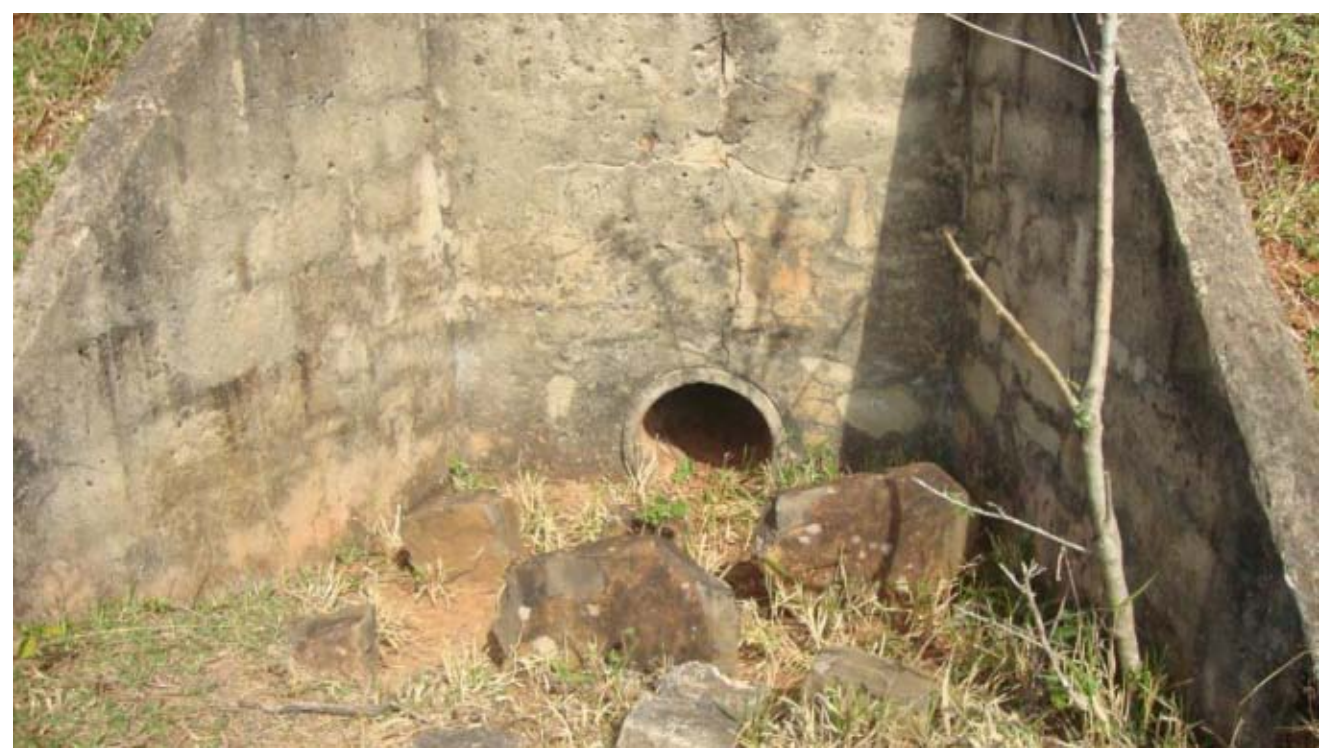

Figura 54: Blocos de rocha dispostos na frente de uma saída de tubulação para contenção da velocidade do escoamento. 


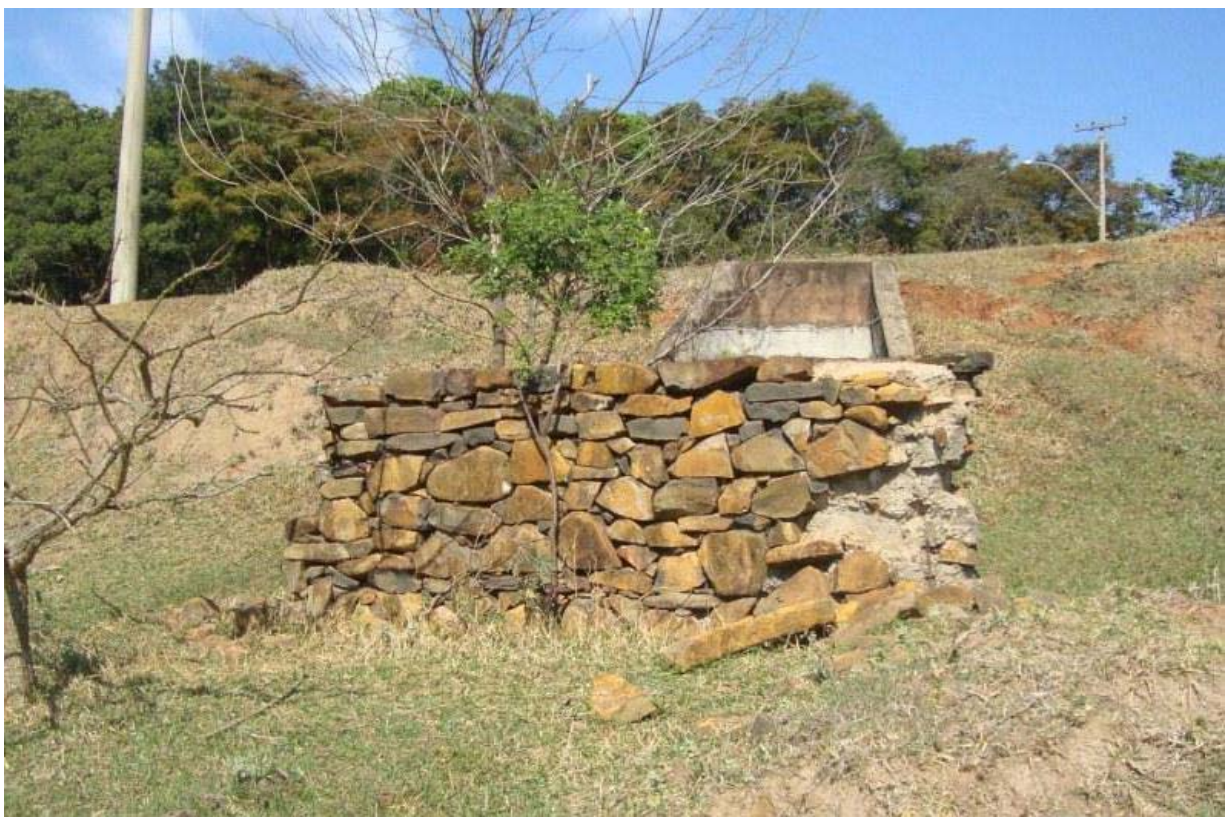

Figura 55: Muro de contenção posicionado na frente de uma saída de tubulação para contenção da velocidade do escoamento.

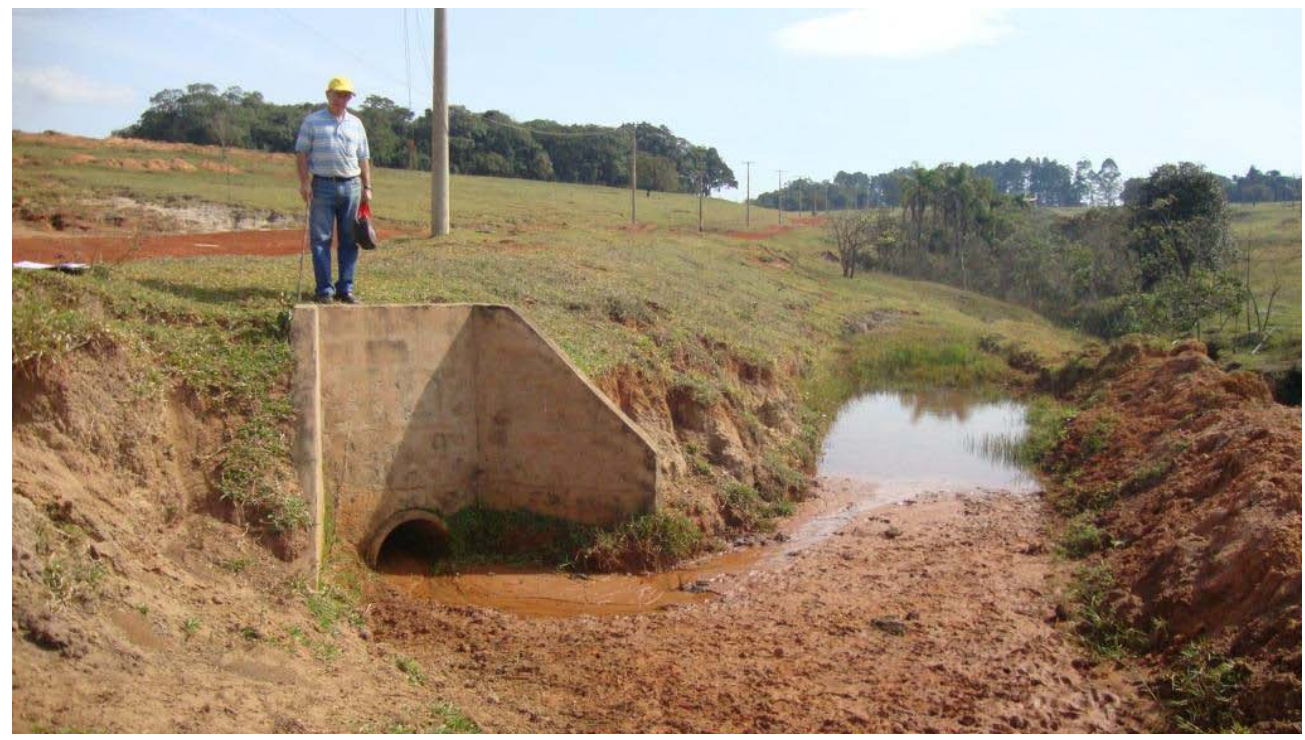

Figura 56: Cordão de nível construído na frente de uma saída de tubulação para evitar que o escoamento superficial acelere a erosão no local.

Recentemente, a área próxima ao córrego, que concentra as feições de grande porte foi cercada, visando impedir o acesso do gado, que ao caminhar contribui para a desagregação do solo, e cujas trilhas favorecem o escoamento superficial concentrado. 


\subsubsection{Análise da eficiência das medidas de recuperação de erosão}

A utilização da pastagem como cobertura vegetal, objetivando o controle da erosão, atua no sentido de prevenir o processo, protegendo o solo. Dado que essa não é a vegetação nativa do local, sua adoção deveria ser acompanhada de cuidados. Entretanto, o que se observou na área, foi que sua utilização, em conjunto com a criação intensiva de gado, foi ineficiente na proteção do solo, o que acarretou o surgimento de locais que facilitaram a ação erosiva do escoamento. Para que essa técnica seja utilizada com sucesso, devem ser adotadas práticas de manejo, como o ressemeio periódico, o controle do número de animais por área, o rodízio de pastagem, o uso de fertilizantes, entre outros.

Os cordões de nível, também atuam no sentido de proteger as encostas da ação do escoamento superficial acelerado, e foram adequadamente construídos acompanhando o relevo. Porém, através dos trabalhos de campo, verificou-se que o espaçamento entre essas estruturas não era adequado, e que essa medida não foi adotada em áreas próximas ao córrego. De um modo geral, a adoção conjunta dos cordões de nível e da cobertura do solo por pastagem não foi eficiente na proteção total das encostas da Área 1, dada a presença de sulcos e ravinas em alguns trechos, próximos aos cordões. No que se refere às características geométricas dessa estrutura, recomenda-se que sua largura seja entre 1,5 e 2 metros, e não 4 metros como foi observado. Por sua vez, o espaçamento deve ser em torno de 10 a 20 metros, mas em alguns pontos foram identificados valores de até $30 \mathrm{~m}$. Outro aspecto importante que deve ser considerado é que essa medida é recomendada para inclinações suaves, justificando-se assim a ausência de cordões nas áreas próximas ao canal, que são mais inclinadas.

O desvio de parcela do escoamento superficial das partes superiores das encostas para áreas próximas aos canais de drenagem, através das obras de microdrenagem, não atingiu o sucesso pretendido na proteção das ruas e das próprias encostas, dado a presença de sulcos e ravinas nas mesmas, como foi apresentado anteriormente. Além disso, as saídas dessas tubulações próximas à drenagem ocasionaram um novo problema de erosão, que é acentuado pelo escoamento superficial concentrado proveniente da rua principal, e que atuam diretamente na dimensão e evolução das feições erosivas de grande porte que margeiam o canal. Nesse contexto citam-se as medidas adotadas para barrar e diminuir a velocidade do fluxo superficial originado na saída das tubulações. Observou-se que os blocos de rocha e o muro de contenção não alcançaram a eficiência esperada, mas, por outro lado, o cordão de nível foi eficaz em conter o escoamento acelerado, dado a presença de água acumulada a montante dessa estrutura. 
Quanto à aplicação das estruturas de microdrenagem, pode-se afirmar que os problemas relacionados a essa técnica indicam a falta de estudos para a determinação da vazão, da área de captação e de questões estruturais, que resultaram no seu subdimensionamento. Faltou ainda determinar a configuração ideal das estruturas, e utiliza-las de forma correta, ou seja, conduzindo adequadamente o escoamento, e prevenindo erosão; e não o intensificando, como foi observado. A utilização de blocos de rocha, muro de contenção, e cordão de nível para diminuir a ação erosiva do escoamento superficial concentrado, proveniente das tubulações, por sua vez, não foi adequada. Nesse caso, a solução seria melhorar o sistema de microdrenagem, eliminando os problemas relacionados ao seu dimensionamento e disposição no terreno; e ainda, poderiam ser empregados dissipadores de energia, como escadas hidráulicas ou enrocamento, devidamente planejados, nas áreas próximas ao canal principal.

O dique ou barreira de proteção empregado na lateral da rua principal não apresentou grande eficiência na proteção da área que abriga as feições principais, uma vez que as feições apresentam-se ativas, e que a própria barreira apresenta sinais de degradação. No contexto da ocupação urbana, a melhor alternativa a essa estrutura seria a utilização de obras de microdrenagem, como canaletas, que conduziriam a água do escoamento pluvial de forma adequada, evitando sua ação erosiva.

No que se refere à cerca que foi disposta no entorno das feições de grande porte, desde que sua execução e manutenção sejam adequadas, esta cumprirá o objetivo de impedir a ação de pisoteamento, e a intensificação do escoamento por meio de trilhas do gado.

Sob uma ótica geral, verificou-se que nessa área nenhuma iniciativa se deu no sentido de recuperar as feições de grande porte. Para isso as feições teriam de ser aterradas, em conjunto da construção de estruturas de drenagem e de obras de retaludamento. Dado o custo envolvido em obras dessa magnitude, uma alternativa seria apenas controlar o processo por meio de obras de drenagem mais simples, e do reflorestamento de toda a área próxima ao canal. Observou-se também que a maioria das técnicas adotadas tinha como objetivo apenas proteger as encostas, visando a retomada do loteamento. Porém, muitas foram mal dimensionadas, sendo insuficientes, e em alguns casos, agravantes no controle da erosão. Algumas melhorias seriam necessárias para a manutenção dessas técnicas, como a correção dos cordões de nível, e a manutenção da pastagem. E ainda, vale ressaltar que a melhoraria do sistema de microdrenagem é imprescindível para a ocupação urbana nesse local. 


\section{2. Área 2 e Área 3}

\subsubsection{Características básicas}

A Área 2 localiza-se na zona geomorfológica da Depressão Periférica (Figura 41), em uma bacia hidrográfica de quarta ordem, com altitudes que variam entre 505 e 615 metros. Em sequência, a Área 3, também localizada na Depressão Periférica, constitui uma bacia hidrográfica de segunda ordem, com altitudes variando entre 535 e 640 metros.

No que se refere aos materiais inconsolidados, conforme pode ser observado na Figura 41, em ambas as áreas são encontrados os residuais da Formação Pirambóia e os Retrabalhados Arenosos de Topo.

Os Residuais da Formação Pirambóia são solos arenosos variando entre médio e fino, com valor de $\rho_{s}$ (massa específica dos sólidos) entre 2,66 e $2,7 \mathrm{~g} / \mathrm{cm}^{3}$, muito próximos ao do quartzo. Fernandes (2003) e Yamanouth (2003) realizaram a caracterização química e física desse material, por meio de diferentes ensaios, cujos resultados podem ser observados nas Tabelas 7 e 8 a seguir.

Tabela 7: Caracterização química e física dos materiais inconsolidados residuais da Formação Pirambóia. (FERNANDES, 2003).

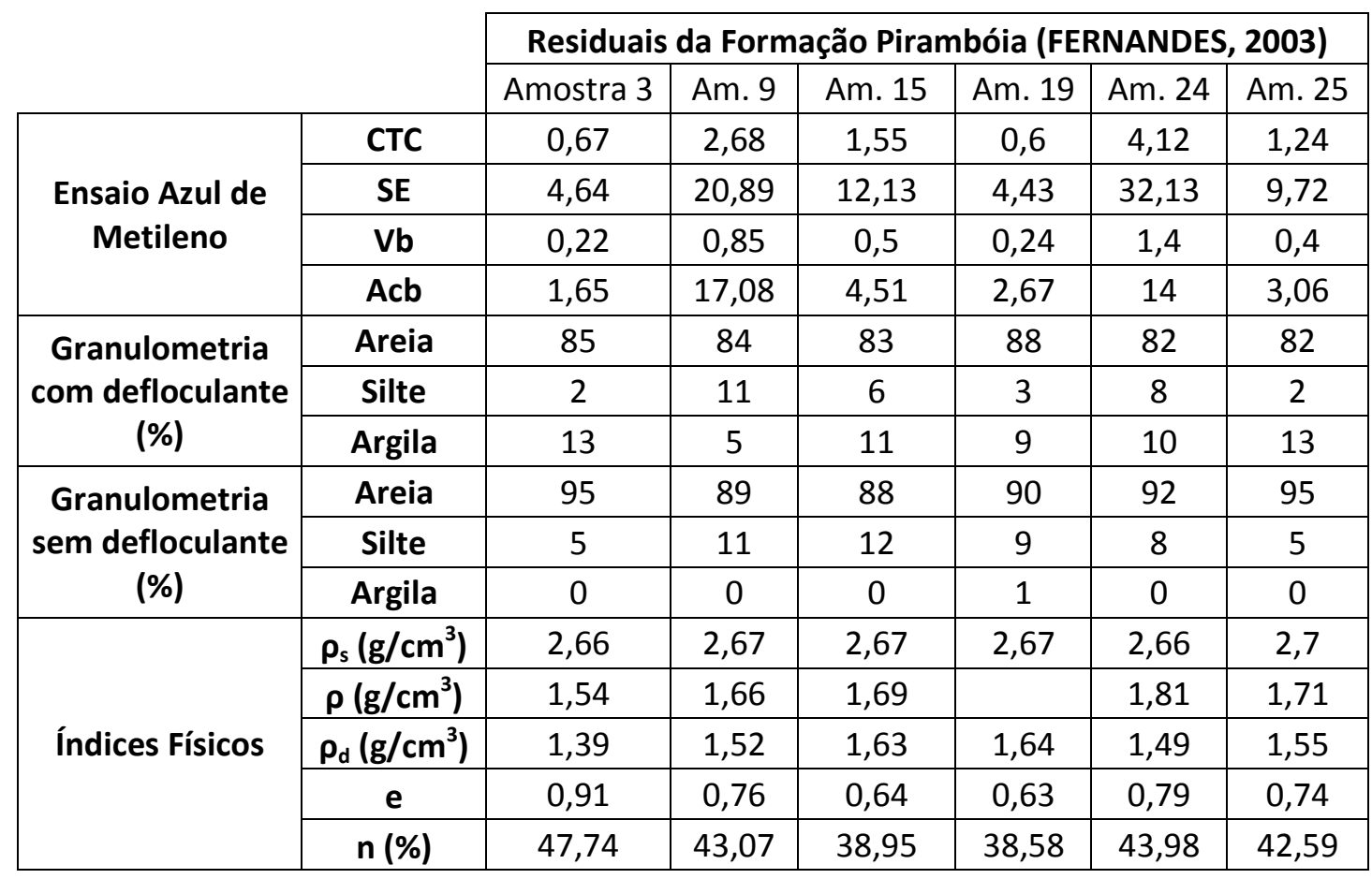


Tabela 8: Caracterização química e física dos materiais inconsolidados residuais da Formação Pirambóia. (YAMANOUTH, 2003).

\begin{tabular}{|c|c|c|c|c|c|c|c|}
\hline & \multicolumn{6}{|c|}{ Residuais da Formação Pirambóia (YAMANOUTH, 2003) } \\
\hline & & Amostra 25 & Am. 26 & Am. 28 & Am. 24 & Am. 7 & Am. 29 \\
\hline \multirow{4}{*}{$\begin{array}{l}\text { Ensaio Azul de } \\
\text { Metileno }\end{array}$} & CTC & 0,5 & 0,5 & 1,2 & 0,3 & 1,1 & 0,8 \\
\hline & SE & 4 & 4 & 9 & 3 & 6 & 4 \\
\hline & Vb & 0,17 & 0,15 & 0,38 & 0,11 & 0,34 & 0,26 \\
\hline & Acb & 3 & 3,2 & 3,2 & 2,5 & 3,2 & 4,3 \\
\hline \multirow{3}{*}{$\begin{array}{c}\text { Granulometria } \\
\text { com } \\
\text { Defloculante (\%) }\end{array}$} & Areia & 93,4 & 93,4 & 84,2 & 94 & 91 & 89,5 \\
\hline & Silte & 1 & 1,9 & 1 & 1,6 & 1,5 & 2,3 \\
\hline & Argila & 5,6 & 4,7 & 11,8 & 4,4 & 7,5 & 8,2 \\
\hline \multirow{3}{*}{$\begin{array}{c}\text { Granulometria } \\
\text { sem } \\
\text { Defloculante (\%) }\end{array}$} & Areia & 99,5 & 99,2 & 39 & 100 & 97,5 & 96,2 \\
\hline & Silte & 0 & 0,8 & 12 & 0 & 2,3 & 3,8 \\
\hline & Argila & 0 & 0 & 0 & 0 & 0,2 & 0 \\
\hline \multirow{5}{*}{ Índices Físicos } & $\rho_{s}\left(\mathrm{~g} / \mathrm{cm}^{3}\right)$ & 2,624 & 2,648 & 2,625 & 2,64 & 2,645 & 2,611 \\
\hline & $\rho\left(\mathrm{g} / \mathrm{cm}^{3}\right)$ & - & - & - & - & - & - \\
\hline & $\rho_{d}\left(\mathrm{~g} / \mathrm{cm}^{3}\right)$ & 1,65 & 1,597 & 1,57 & 1,631 & 1,585 & 1,494 \\
\hline & e & 0,59 & 0,66 & 0,67 & 0,62 & 0,67 & 0,75 \\
\hline & $n(\%)$ & 37,12 & 39,69 & 40,19 & 38,22 & 0,75 & 42,78 \\
\hline
\end{tabular}

Yamanouth (2003) descreveu ainda o perfil típico desse material como sendo constituído por: rocha sã, rocha muito alterada, solo saprolítico e solo residual. A rocha sã, como foi mencionada, compreende os arenitos da Formação Pirambóia. A rocha muito alterada, segundo a autora, apresenta coloração alaranjada e estruturas primárias como estratificações cruzadas de pequeno e médio porte. O solo saprolítico consiste em um material arenoso de coloração rosada, de cerca de 0,5 metro de espessura, onde podem ser encontrados matacões de rocha branda. E por último, o solo residual consiste em um material arenoso de granulometria média a fina, com coloração amarela esbranquiçada e com espessuras que variam entre 4 e 5 metros.

Por fim, a autora realizou ensaios de absorção de água e de perda de massa que possibilitaram o cálculo da erodibilidade, tanto pelo método de Pejon (1992), quanto pelo método de Nogami \& Villibor (1979), cujos resultados se encontram na Tabela 9 e indicam, de um modo geral, baixa resistência à erosão. 
Tabela 9: Erodibilidade dos materiais inconsolidados residuais da Formação Pirambóia, obtidos pelos métodos de PEJON (1992), e de NOGAMI e VILLIBOR (1979) (YAMANOUTH, 2003).

\begin{tabular}{|c|c|c|}
\cline { 2 - 3 } \multicolumn{1}{c|}{} & \multicolumn{2}{c|}{ Residuais da Formação Pirambóia } \\
\cline { 2 - 3 } & $\begin{array}{c}\text { Erodibilidade - } \\
\text { PEJON (1992) }\end{array}$ & $\begin{array}{c}\text { Erodibilidade - NOGAMI } \\
\text { e VILLIBOR (1979) }\end{array}$ \\
\hline Amostra 25 & 1,06 & 1,38 \\
\hline Amostra 26 & 0,73 & 0,95 \\
\hline Amostra 28 & 0,62 & 0,81 \\
\hline Amostra 24 & 0,65 & 0,85 \\
\hline Amostra 7 & 0,44 & 0,57 \\
\hline Amostra 29 & 0,34 & 0,44 \\
\hline
\end{tabular}

Por sua vez, os materiais inconsolidados Retrabalhados Arenosos de Topo, caracterizados por Yamanouth (2003), indicaram a presença de uma grande quantidade de finos, com até $27 \%$ de argila; e ainda, apresentaram coloração avermelhada e espessura de cerca de 3 metros. A caracterização física e química desse material foi realizada tanto por Yamanouth (2003) quanto por Fernandes (2003), cujos resultados estão apresentados a seguir.

Tabela 10: Caracterização química e física dos materiais inconsolidados Retrabalhados Arenosos de topo (FERNANDES, 2003).

\begin{tabular}{|c|c|c|c|c|c|c|c|c|}
\hline & & \multicolumn{7}{|c|}{ Retrabalhado Arenoso de Topo (FERNANDES, 2003) } \\
\hline & & Am. 1 & Am. 2 & Am. 8 & Am. 13 & Am. 17 & Am. 18 & Am. 23 \\
\hline \multirow{4}{*}{$\begin{array}{c}\text { Ensaio Azul de } \\
\text { Metileno }\end{array}$} & CTC & 0,53 & 0,49 & 1,04 & 2,15 & 0,47 & 1 & 3 \\
\hline & SE & 4,11 & 3,8 & 8,41 & 16,81 & 3,66 & 7,79 & 23,41 \\
\hline & Vb & 0,17 & 0,12 & 0,34 & 0,22 & 0,15 & 0,32 & 0,96 \\
\hline & Acb & 0,94 & 1,5 & 4,29 & 6,87 & 7,47 & 6,37 & 9,57 \\
\hline \multirow{3}{*}{$\begin{array}{c}\text { Granulometria } \\
\text { com Defloculante } \\
\text { (\%) }\end{array}$} & Areia & 73 & 88 & 86 & 85 & 40 & 90 & 79 \\
\hline & Silte & 9 & 4 & 6 & 5 & 58 & 5 & 11 \\
\hline & Argila & 18 & 8 & 8 & 10 & 2 & 5 & 10 \\
\hline \multirow{3}{*}{$\begin{array}{c}\text { Granulometria } \\
\text { sem Defloculante } \\
(\%)\end{array}$} & Areia & 99 & 94 & 94 & 91 & 79 & 92 & 88 \\
\hline & Silte & 1 & 4 & 2 & 6 & 21 & 4 & 10 \\
\hline & Argila & 0 & 2 & 4 & 3 & 0 & 4 & 2 \\
\hline \multirow{5}{*}{ Índices Físicos } & $\rho_{s}\left(\mathrm{~g} / \mathrm{cm}^{3}\right)$ & 2,68 & 2,72 & 2,72 & 2,68 & 2,73 & 2,67 & 2,67 \\
\hline & $\rho\left(\mathrm{g} / \mathrm{cm}^{3}\right)$ & 1,69 & 1,71 & 1,71 & 1,63 & 1,69 & 1,54 & \\
\hline & $\rho_{d}\left(\mathrm{~g} / \mathrm{cm}^{3}\right)$ & 1,63 & 1,59 & 1,52 & 1,36 & 1,63 & 1,39 & 1,41 \\
\hline & e & 0,64 & 0,71 & 0,79 & 0,97 & 0,67 & 0,92 & 0,89 \\
\hline & n (\%) & 39,18 & 41,54 & 44,12 & 49,25 & 40,29 & 47,94 & 47,19 \\
\hline
\end{tabular}


Tabela 11: Caracterização química e física dos materiais inconsolidados Retrabalhados Arenosos de Topo (YAMANOUTH, 2003).

\begin{tabular}{|c|c|c|c|c|c|c|c|c|c|}
\hline & \multicolumn{8}{|c|}{ Retrabalhado Arenoso de Topo (YAMANOUTH, 2003) } \\
\hline & & Am. 32 & Am. 33 & Am. 6 & Am. 11 & Am. 34 & Am. 17 & Am. 23 & Am. 27 \\
\hline \multirow{4}{*}{$\begin{array}{l}\text { Ensaio Azul de } \\
\text { Metileno }\end{array}$} & CTC & 0,9 & 0,9 & 1,1 & 1,9 & 0,9 & 0,8 & 0,5 & 0,7 \\
\hline & SE & 7 & 7 & 8 & 15 & 7 & 6 & 4 & 5 \\
\hline & Vb & 0,3 & 0,3 & 0,35 & 0,62 & 0,3 & 0,26 & 0,15 & 0,22 \\
\hline & Acb & 3,5 & 3,6 & 2 & 2,3 & 1,5 & 2,1 & 1,8 & 2,2 \\
\hline \multirow{3}{*}{$\begin{array}{c}\text { Granulometria } \\
\text { com } \\
\text { Defloculante } \\
\text { (\%) }\end{array}$} & Areia & 88 & 88,9 & 80,3 & 64 & 74 & 85,3 & 88,3 & 88,5 \\
\hline & Silte & 36 & & & 85 & 52 & 23 & 35 & 88,3 \\
\hline & Argila & 8,4 & 8,2 & 17,6 & 27,5 & 20,8 & 12,3 & 8,2 & 88,5 \\
\hline \multirow{3}{*}{$\begin{array}{c}\text { Granulometria } \\
\text { sem } \\
\text { Defloculante } \\
\text { (\%) }\end{array}$} & Areia & 96 & 95,2 & 93 & 66 & 81,5 & 92,5 & 91 & 93,2 \\
\hline & cilts & 3,2 & 20 & 6,2 & 19,5 & 11,9 & 20 & 20 & 6,8 \\
\hline & Argila & 0,8 & 9 & 0,8 & 14,5 & 6 & 3,9 & 0,2 & 0 \\
\hline \multirow{5}{*}{ Índices Físicos } & $\rho_{\mathrm{s}}\left(\mathrm{g} / \mathrm{cm}^{3}\right)$ & 2,64 & 2,59 & 2,67 & 2,74 & 2,74 & 2,657 & 2,641 & 2,649 \\
\hline & $\rho\left(\mathrm{g} / \mathrm{cm}^{3}\right)$ & - & - & - & - & - & - & - & - \\
\hline & $\rho_{d}\left(g / \mathrm{cm}^{3}\right)$ & 1,561 & 1,529 & 1,542 & 1,414 & 1,33 & 1,527 & 1,435 & 1,497 \\
\hline & e & 0,69 & 0,69 & 0,73 & 0,93 & 1,06 & 0,77 & 0,84 & 0,74 \\
\hline & $\mathrm{n}(\%)$ & 40,87 & 40,97 & 42,29 & 48,32 & 51,37 & 42,53 & 45,66 & 43,49 \\
\hline
\end{tabular}

Yamanouth (2003) realizou ainda os ensaios de absorção de água e de perda de massa, para diferentes amostras, calculando assim os valores de erodibilidade tanto pelo método de Pejon (1992), quanto pelo método de Nogami \& Villibor (1979). Os resultados obtidos pela autora estão representados na Tabela 12. É possível verificar uma grande variabilidade nos valores encontrados, porém a autora afirma que o valor baixo é mais condizente com as observações de campo, dada a presença de feições erosivas no local. Fernandes (2003) também caracterizou esse material, em diferentes pontos de amostragem, sendo seus resultados coerentes com os descritos por Yamanouth (2003). 
Tabela 12: Erodibilidade dos materiais inconsolidados Retrabalhados Arenosos de Topo, obtidos pelos métodos de PEJON (1992), e de NOGAMI e VILLIBOR (1979) (YAMANOUTH, 2003).

\begin{tabular}{|c|c|c|}
\cline { 2 - 3 } \multicolumn{1}{c|}{} & \multicolumn{2}{c|}{ Retrabalhados Arenosos de Topo } \\
\cline { 2 - 3 } \multicolumn{1}{c|}{} & $\begin{array}{c}\text { Erodibilidade - } \\
\text { PEJON (1992) }\end{array}$ & $\begin{array}{c}\text { Erodibilidade - NOGAMI e } \\
\text { VILLIBOR (1979) }\end{array}$ \\
\hline Amostra 32 & 0,69 & 0,89 \\
\hline Amostra 33 & 1,58 & 2,06 \\
\hline Amostra 6 & 25,23 & 32,79 \\
\hline Amostra 11 & 0,64 & 0,83 \\
\hline Amostra 34 & 3,82 & 4,97 \\
\hline Amostra 17 & 0,89 & 1,16 \\
\hline Amostra 23 & 1,09 & 1,42 \\
\hline Amostra 27 & 0,84 & 1,1 \\
\hline
\end{tabular}

\subsubsection{Característica do processo erosivo: Área 2}

O tipo de ocupação e uso do solo existente na Área 2 se alterou ao longo dos anos, sendo que inicialmente a área era coberta por pastagens, com exceção de alguns trechos onde a vegetação ciliar havia sido mantida. A adoção desse tipo de cobertura do solo envolveu uma etapa de desmatamento, que somada à ação de pisoteamento do solo e surgimento de trilhas de gados, contribuiu para a evolução dos processos erosivos na área, levando ao surgimento de grandes voçorocas, além de sulcos e ravinas. As 14 principais feições erosivas nesse período foram identificadas com auxílio de uma fotografia aérea do ano de 1972, e estão identificadas na Figura 57.

Por volta do ano de 1995, o perímetro urbano de São Pedro passou por uma fase de expansão, de modo que grande parte da Área de estudo passou a ser ocupada por áreas urbanas em consolidação. No ano de 2000 o bairro Jardim Botânico (Área 2) já estava estruturado, com vias de acesso e alguns lotes ocupados. Mas para que a ocupação urbana da área fosse efetiva algumas medidas de controle e recuperação de erosão foram adotadas. Através da fotografia aérea do ano de 2006 pode-se observar a nova configuração dessa área, indicando que a maioria das feições erosivas de grande porte foram recuperadas, dando lugar a delimitações de medidas de recuperação, conforme indicado na Figura 58. 


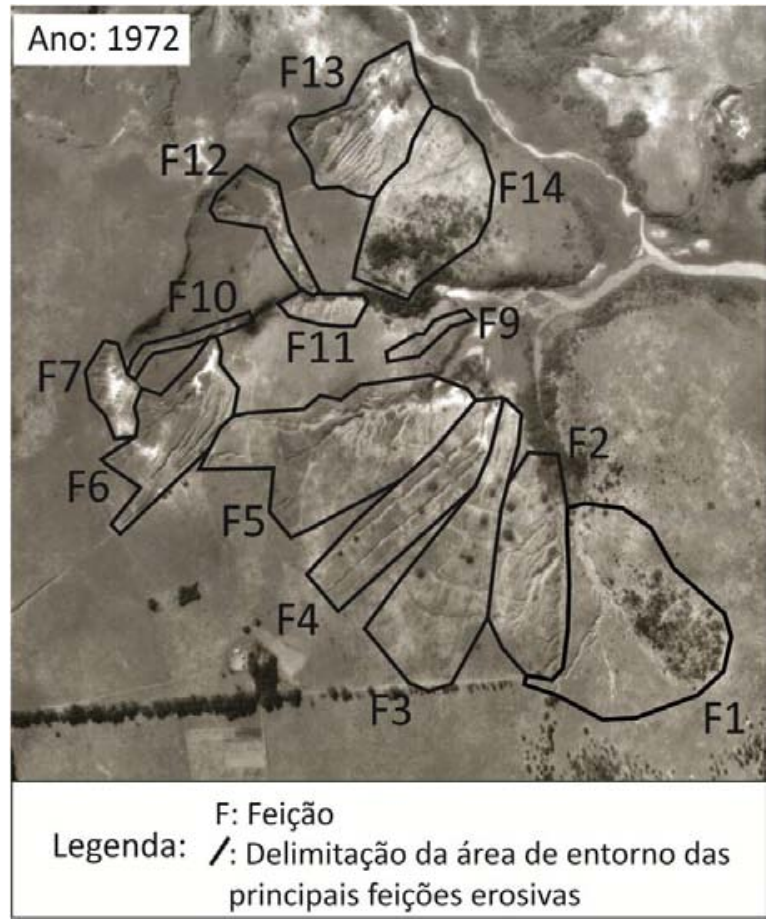

Figura 57: Delimitação dos conjuntos das principais feições de grande porte existentes na Área 2, para o ano de 1972.

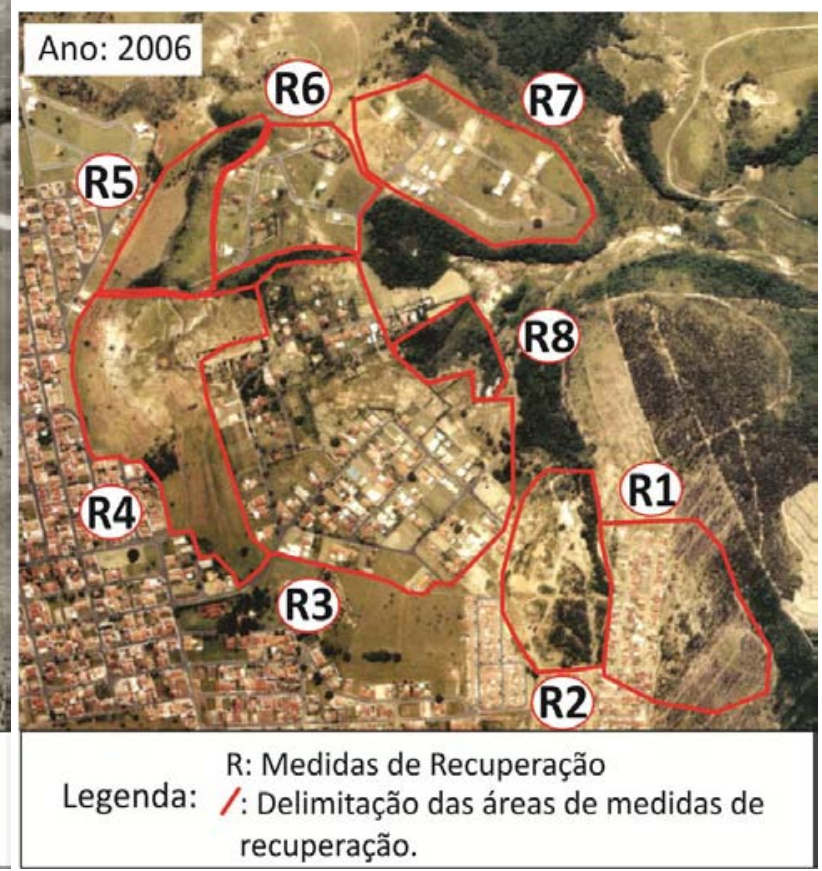

Figura 58: Delimitação das áreas que apresentam diferentes medidas de recuperação da erosão, para o ano de 2006.

Através dos trabalhos de campo verificou-se que duas feições de grande porte foram reativadas na área: a F2 e a F12, e que uma nova surgiu (F15), próxima à feição F2. As principais características geométricas dessas feições, e aspectos relacionados à sua estabilidade estão indicados na Tabela 13. E em sequência, na Figura 59, observa-se a superfície da Área 2, (obtida no Surfer pelo método de interpolação Radial Bases Function), com indicação da localização dessas três feições principais. 
Tabela 13: Caracterização das principais feições erosivas da Área 2.

\begin{tabular}{|c|c|c|c|c|}
\hline Feição & $\begin{array}{l}\text { Comprimento } \\
\text { Médio (m) }\end{array}$ & $\begin{array}{c}\text { Largura } \\
\text { Média }(\mathrm{m})\end{array}$ & \begin{tabular}{|c|} 
Profundidade \\
Média (m)
\end{tabular} & Caracterização \\
\hline F2 & 400 & 80 & 20 a 60 & $\begin{array}{l}\text { Feição contínua de cabeceira, cujo } \\
\text { trecho inicial, próximo à cabeceira, } \\
\text { possui formato em "U", e apresenta-se } \\
\text { bastante estável (primeiros } 120 \\
\text { metros). Nesse ponto há uma } \\
\text { barragem para retenção dos } \\
\text { sedimentos. A jusante da barragem a } \\
\text { feição apresenta certa instabilidade } \\
\text { nas paredes e, sobretudo no fundo, } \\
\text { onde há o afloramento do lençol } \\
\text { freático que escoa interruptamente. } \\
\text { Há ainda pequenas ramificações no } \\
\text { trecho final, que apresentam potencial } \\
\text { de evolução. }\end{array}$ \\
\hline F12 & 100 & 5 a 15 & 4 & $\begin{array}{l}\text { Feição contínua de encosta, reativada } \\
\text { pelo escoamento superficial } \\
\text { concentrado proveniente de uma das } \\
\text { vias do bairro, localizada em um lote } \\
\text { vazio. }\end{array}$ \\
\hline F15 & 4 & 8 & 3 & $\begin{array}{l}\text { Feição descontínua de encosta, } \\
\text { recente, bastante ativa, com presença } \\
\text { de afloramento do lençol freático, e } \\
\text { formação de piping no fundo. }\end{array}$ \\
\hline
\end{tabular}




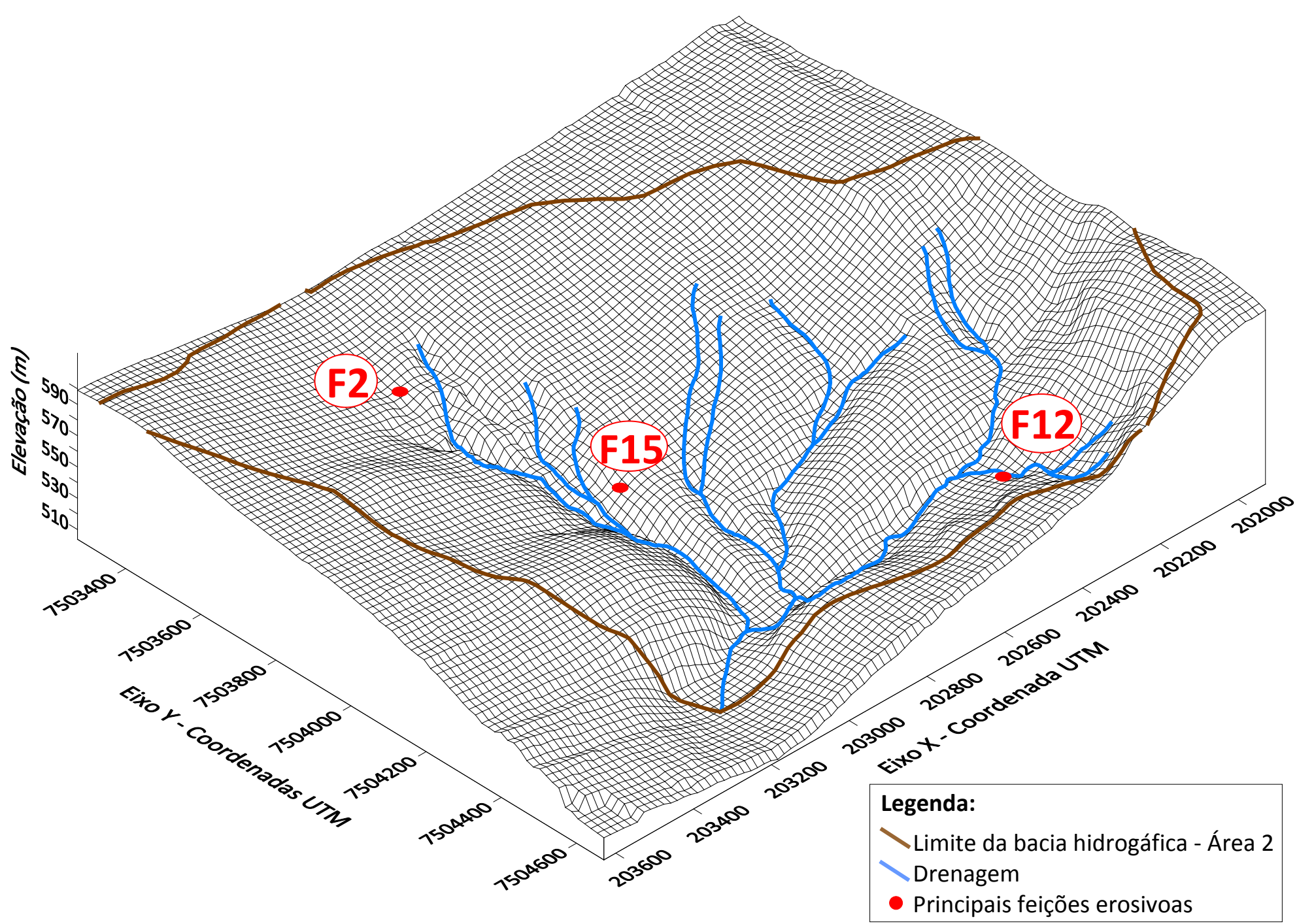

Figura 59: Superfície 3D representativa da Área 2, com localização das principais feições erosivas. 
As Figuras 60 e 61 representam a cabeceira e o comprimento da feição F2, respectivamente, que é a maior feição erosiva dessa área, e que foi reativada após ser recuperada. Em sequência, na Figura 62, pode-se observar a feição F12, que havia sido aterrada, mas que também foi reativada. E finalmente, nas Figuras 63 e 64, tem-se a feição F15, que surgiu em decorrência da pré-disposição do solo à erosão, e do mau posicionamento de uma canaleta.

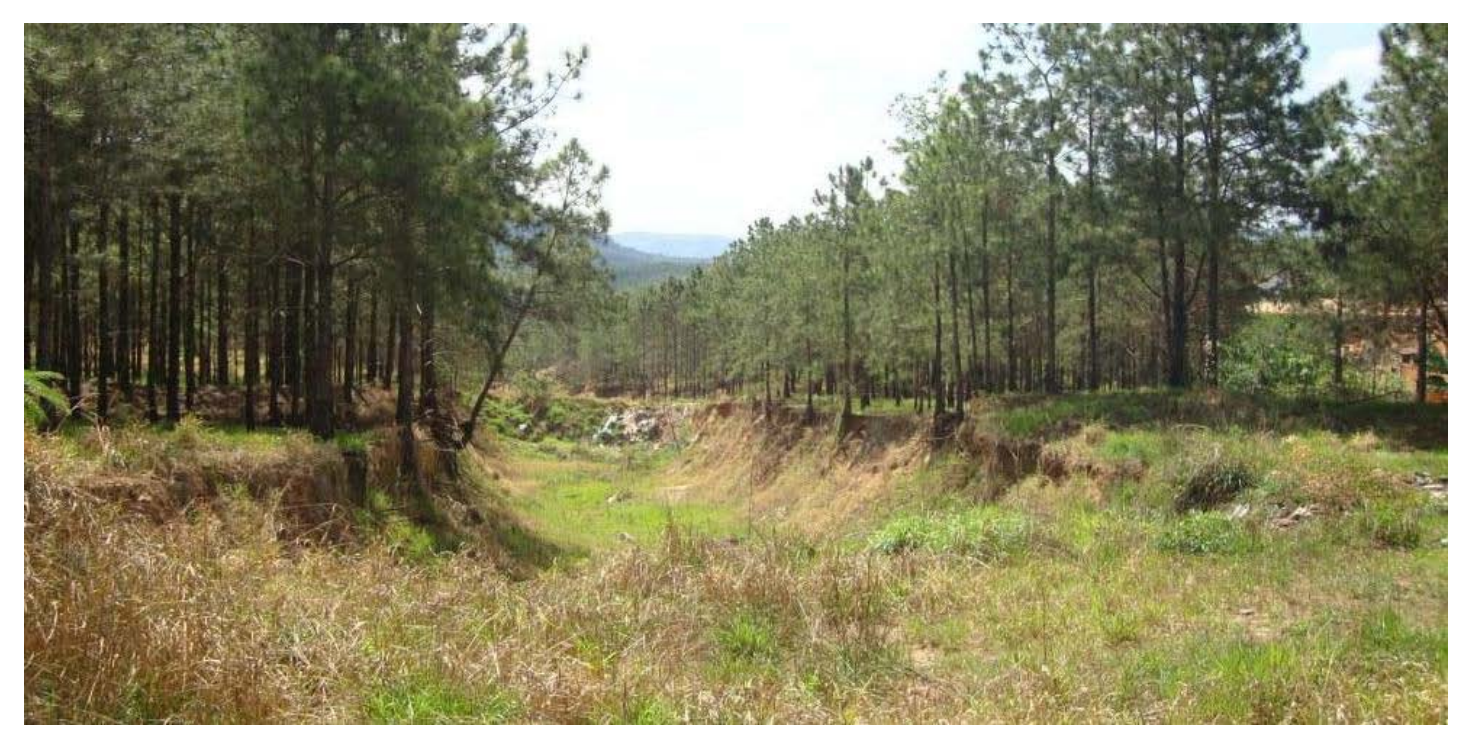

Figura 60: Cabeceira da Feição F2 pertencente à Área 2.

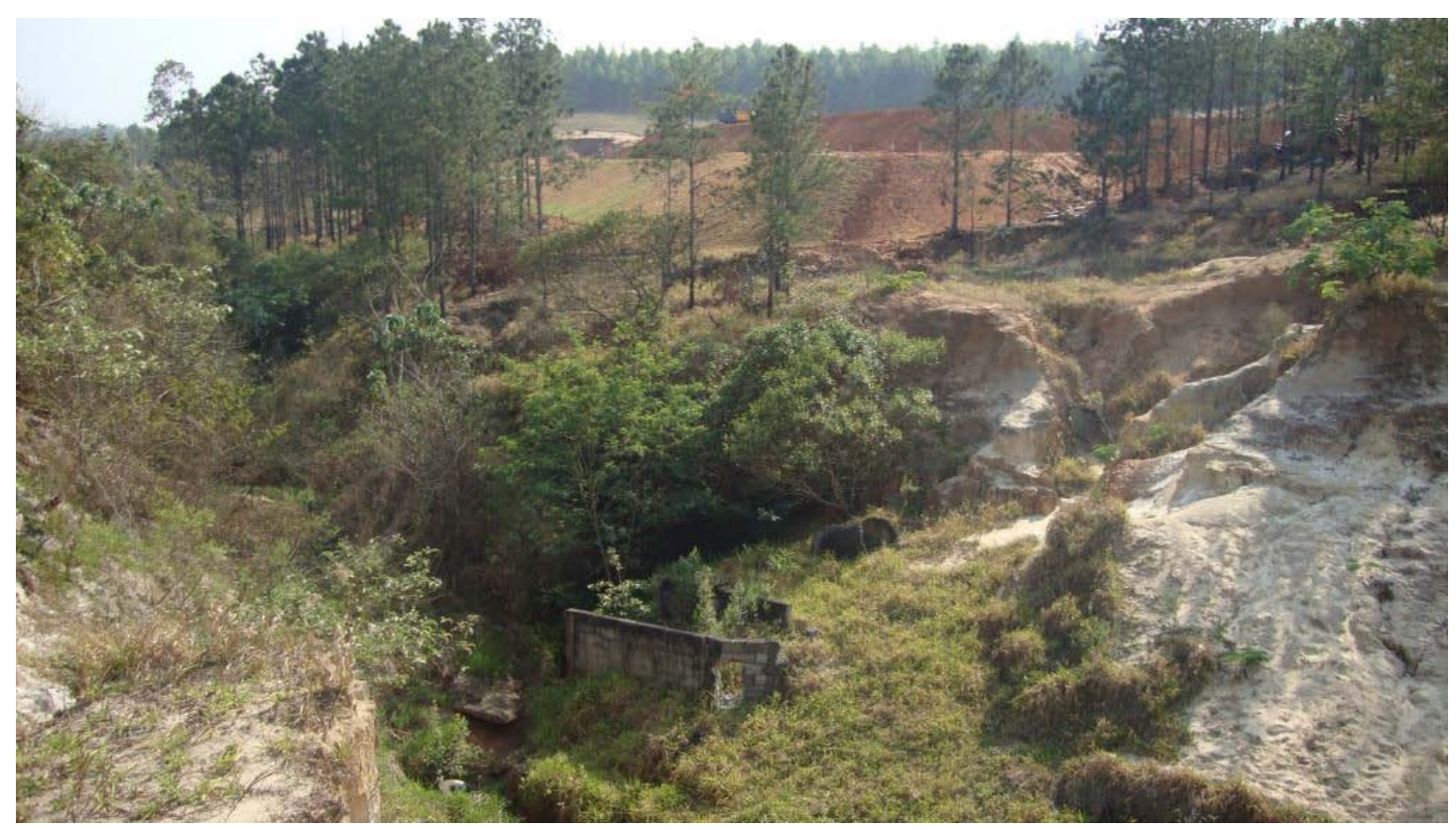

Figura 61: Feição F2, com destaque para a presença de água no interior. 


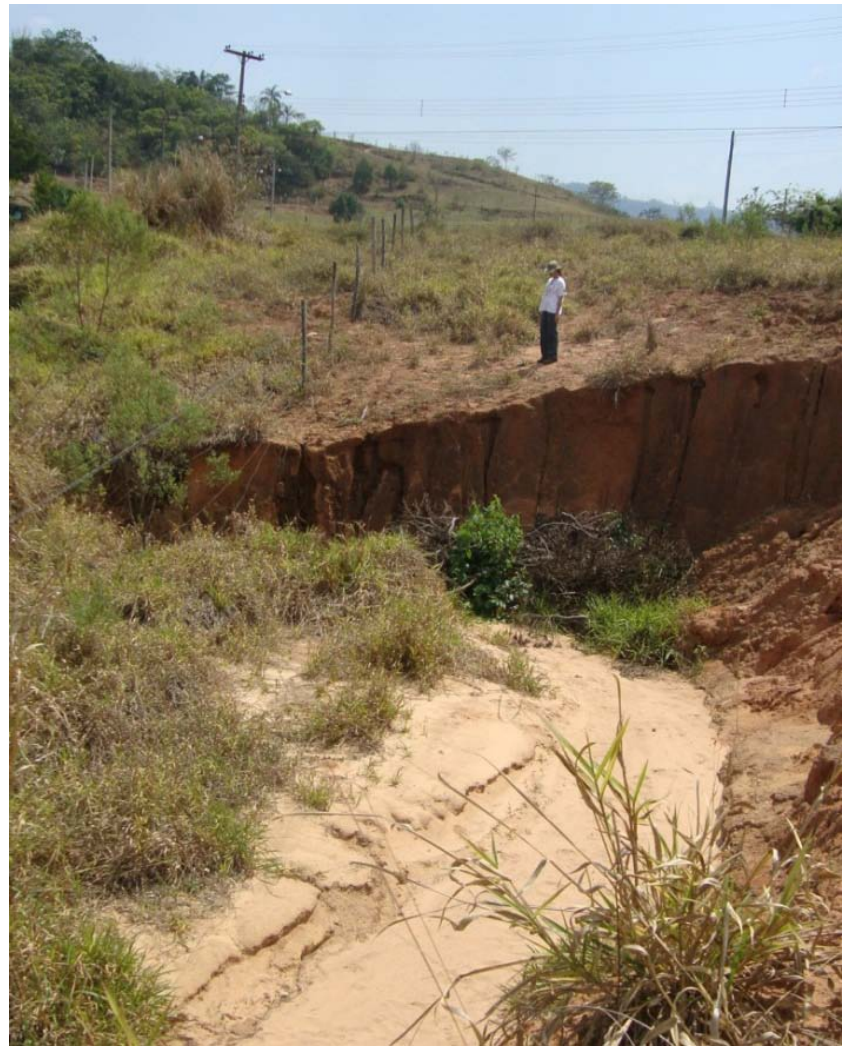

Figura 62: Feição F12 reativada em lotes não ocupados do bairro Jardim Botânico (Área 2).

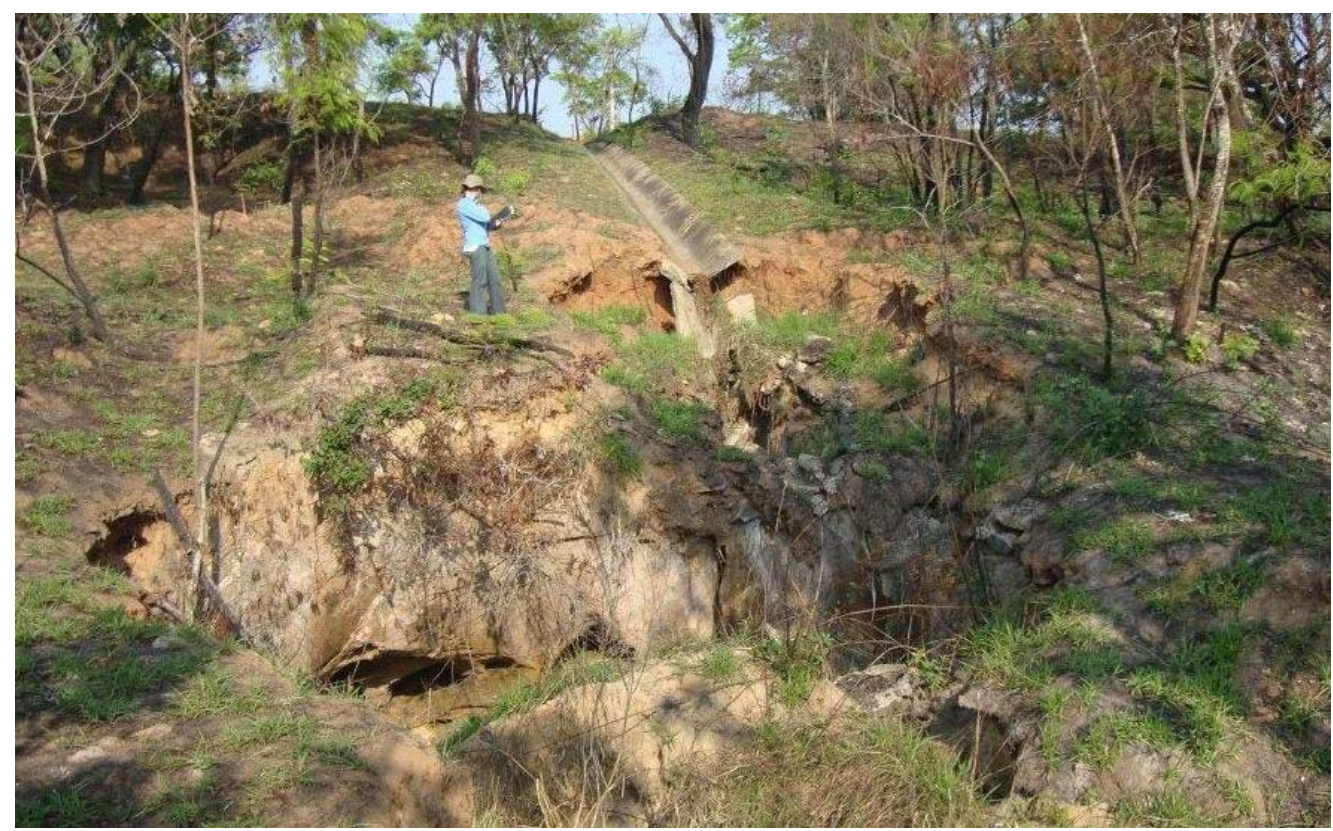

Figura 63: Feição F15, próxima a F2, que surgiu após a ocupação urbana da Área 2. 


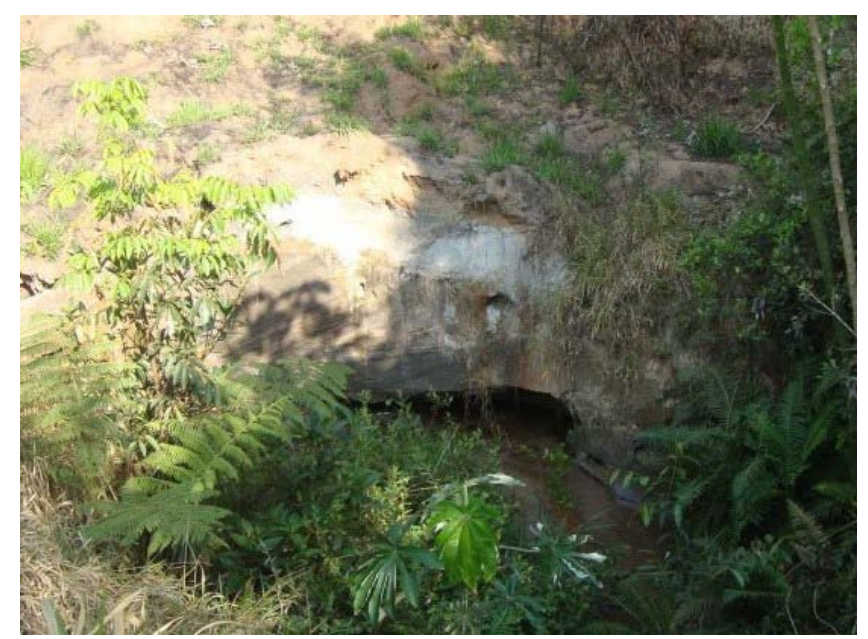

Figura 64: Detalhe para o processo de piping e a presença de água no interior da feição F15.

\subsubsection{Descrição das medidas de recuperação: Área 2}

As atividades de controle e recuperação da erosão empregadas na Área 2 sofreram alterações ao longo dos anos, e puderam ser identificadas pela análise de fotos aéreas dos anos de 1962, 1972, 1988, 1995, 2000 e 2006. Nos primeiros anos, entre 1962 e 1972, quando o uso do solo ainda era a pastagem, foram utilizados cordões de nível ao longo das encostas. Em seguida, entre 1972 e 1988 ocorreram algumas mudanças: em primeiro lugar, na área que abrangia o grupo de feições erosivas F1 (representada na Figura 57), o pasto foi substituído por pinus. Nesse período ainda foi realizado o reflorestamento da área que abrangia o grupo de feições F6 (Figura 57); e o aterramento, reflorestamento, e construção de cordões de nível na área ocupada pelas feições F3 (Figura 57).

Já entre os anos de 1988 e 1995 a alteração do uso e ocupação da área foi definitiva na mudança de cenário das medidas de recuperação. Para proporcionar a implantação do bairro os grupos de feições F1, F3, F4, F5, F6, F7, F10, F13, F14 e parte da F12 foram aterrados, e para proteger o aterro foram feitos cordões de nível apenas nas áreas que eram ocupadas pelas feições F3, F4, F5, F6, F7, F13 e F14. Nesse período, merece destaque as atividades de recuperação realizadas na feição F2: em seu interior escoava esgoto e águas pluviais, que foi canalizado, seguido do aterro da feição. Entre 1995 e 2000, foi possível observar a manutenção dos cordões de nível em alguns trechos, e, principalmente, a ocupação de parte da área pelo loteamento, o que envolveu a construção de vias e de algumas casas, sobretudo nas áreas antes ocupadas pelas feições F3, F4 e F5. Por outro lado, a feição F2, que havia sido recuperada, foi reativada e o sistema de drenagem no seu interior foi destruído, de modo que uma nova 
medida, com o objetivo de conter sua evolução, foi empregada, sendo esta a plantação de pinus em seu entorno, em conjunto da construção de cordões de nível. Além disso, foi construída uma barragem próxima à cabeceira dessa feição, que além de atuar na retenção de sedimentos, atua como uma passarela para a passagem da população. E ainda, parte da feição F12 que havia sido aterrada foi reativada devido ao traçado de vias de acesso em sua proximidade.

Finalmente, pela análise da fotografia do ano de 2006, foi possível delimitar 8 áreas principais de recuperação (Figura 58). Nesse período ocorreu a intensificação da ocupação, sobretudo nas áreas R3, R6 e R7, o que envolveu o aterramento e consolidação das vias. A área R1, que havia sido reflorestada entre 1972 e 1988, teve parte de sua área ocupada por um loteamento de baixo padrão. As áreas R4 e R5, que foram aterradas no passado, não foram ocupadas pelo bairro, permanecendo a cobertura por pastagem, com a presença de cordões de nível. A área R8, por sua vez, consiste em um trecho em que houve recuperação da mata ciliar por iniciativa dos moradores.

A situação atual das áreas de recuperação foi verificada pelos trabalhos de campo, sendo constatado que poucas modificações ocorreram nos últimos 6 anos. As áreas R4 e R5, ainda permanecem cobertas por pastagem, com a presença de cordões de nível para o controle da erosão, com a presença de um pequeno número de animais (Figura 65). Vale ressaltar que a declividade nesses trechos é bastante acentuada, de forma que a construção de casas seria bastante onerosa, o que provavelmente impede a ocupação urbana mais efetiva em curto prazo nesse local. Próximo à área R8 surgiu uma nova iniciativa de revegetação de áreas não ocupadas, próximas ao canal de drenagem, por meio da plantação de mudas de diferentes espécies. Porém verificou-se que nem todas se adaptaram às condições locais (Figura 66). Já na área R2, que compreende a feição F2 reativada, ainda são encontrados a plantação de pinus e os cordões de nível no entorno (Figura 67), assim como a barragem (Figura 68), e estruturas de drenagem no seu interior; porém, os moradores locais passaram a depositar lixo e entulho no interior e entorno da feição, de forma desordenada, e sem intuito de recuperação (Figuras 69 e 70). 


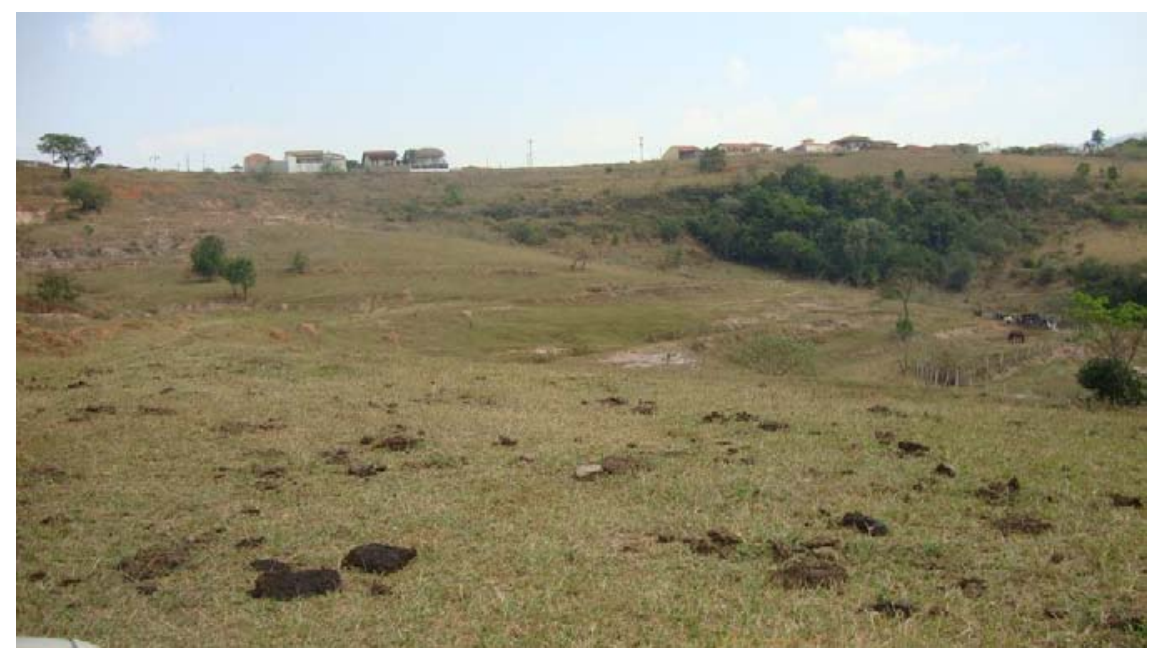

Figura 65: Representação do tipo de uso e de medidas de controle da erosão das áreas R4 e R5.

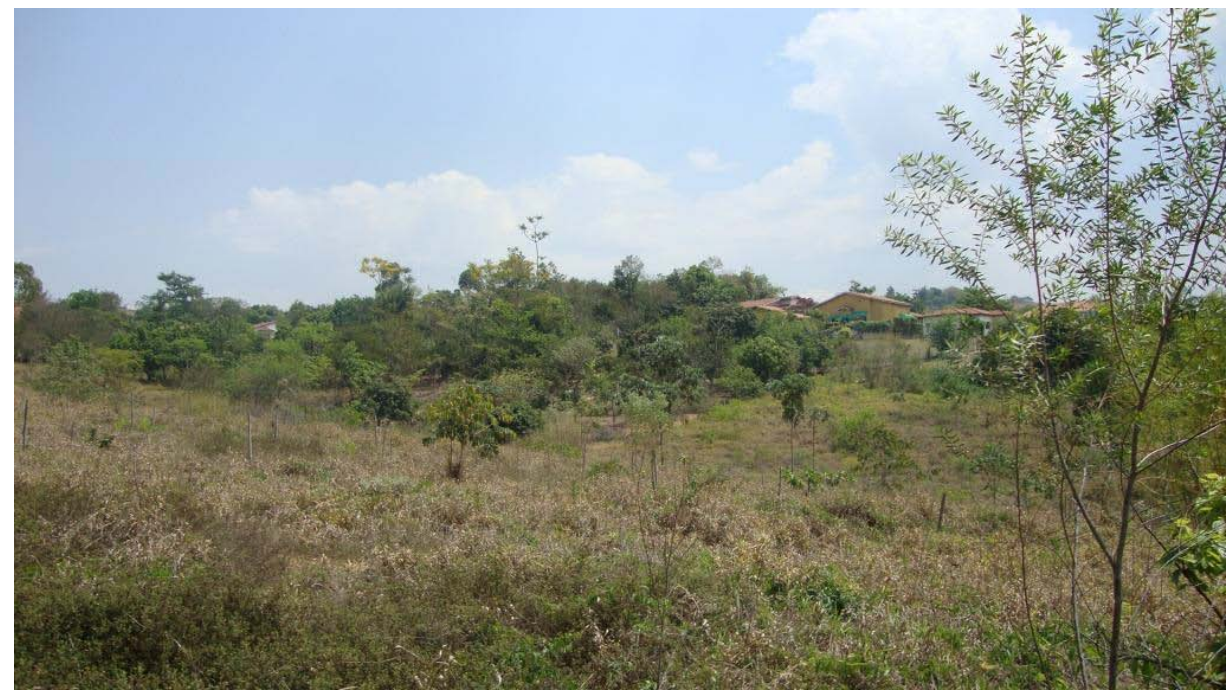

Figura 66: Área próxima à R8 com plantação de mudas, indicando uma iniciativa de revegetação de uma área não ocupada, próxima à drenagem principal. 


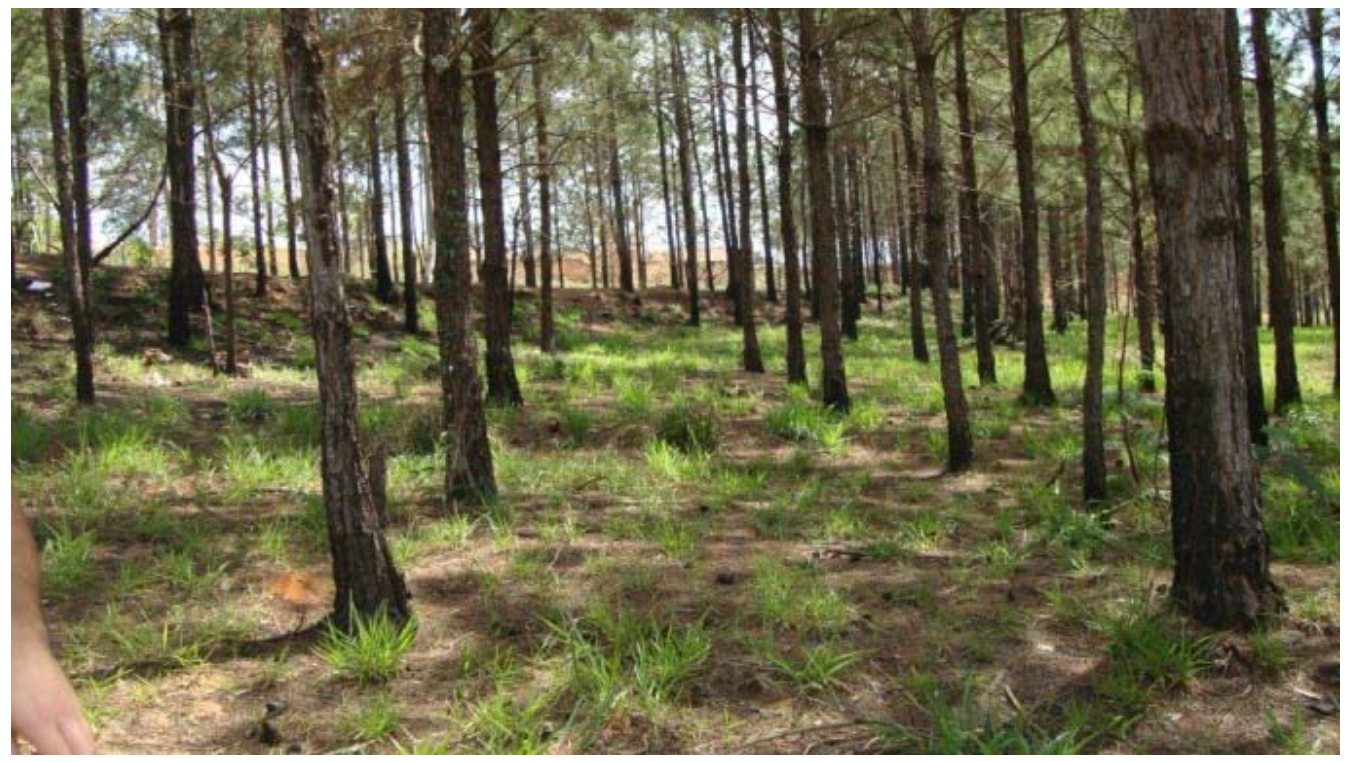

Figura 67: Plantação de pinus em associação com cordões de nível no entorno da feição F2, com o objetivo de controle do processo erosivo.

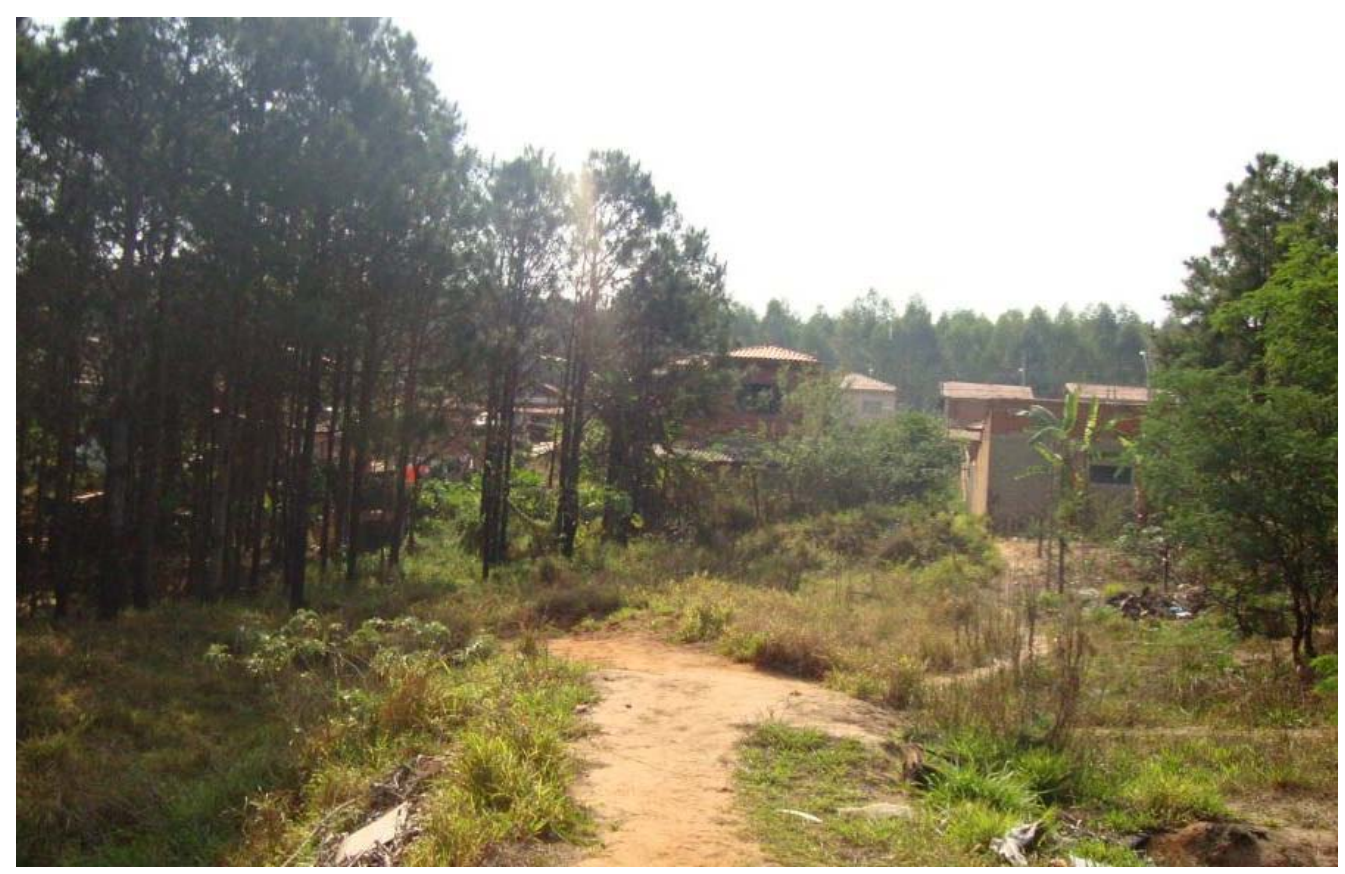

Figura 68: Barragem de sedimento no interior da feição F2. 


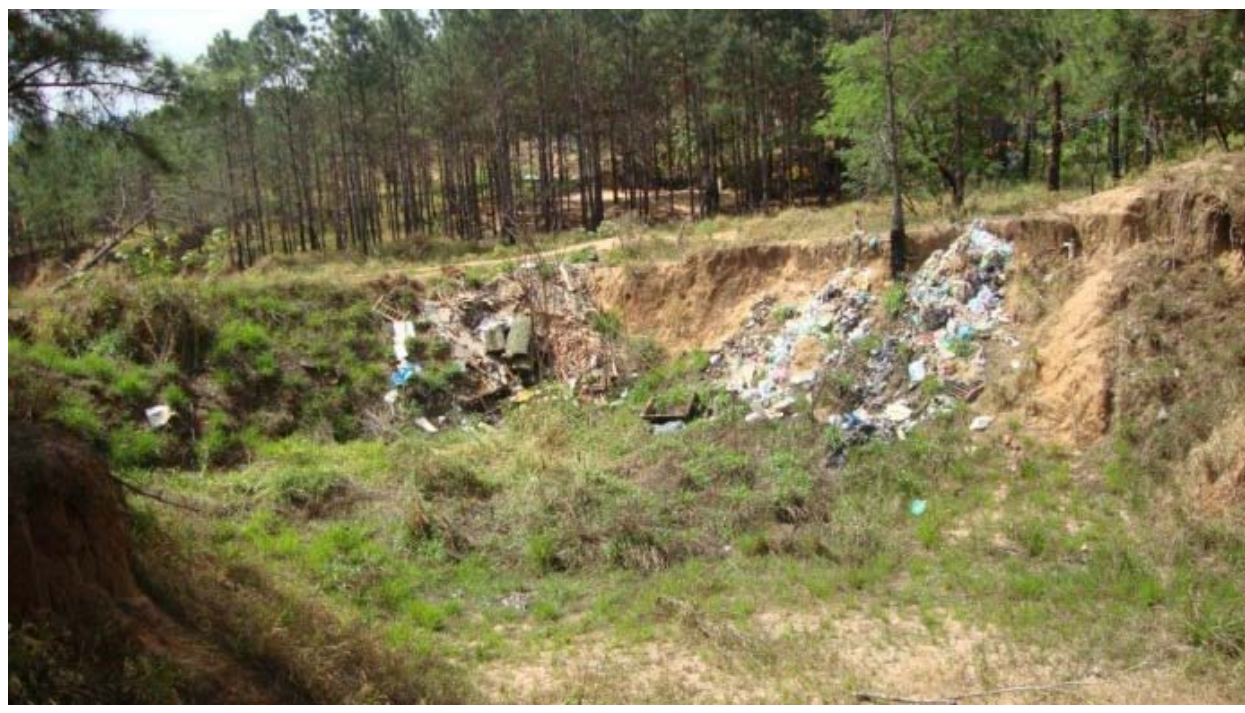

Figura 69: Lixo depositado por moradores no interior da feição F2.

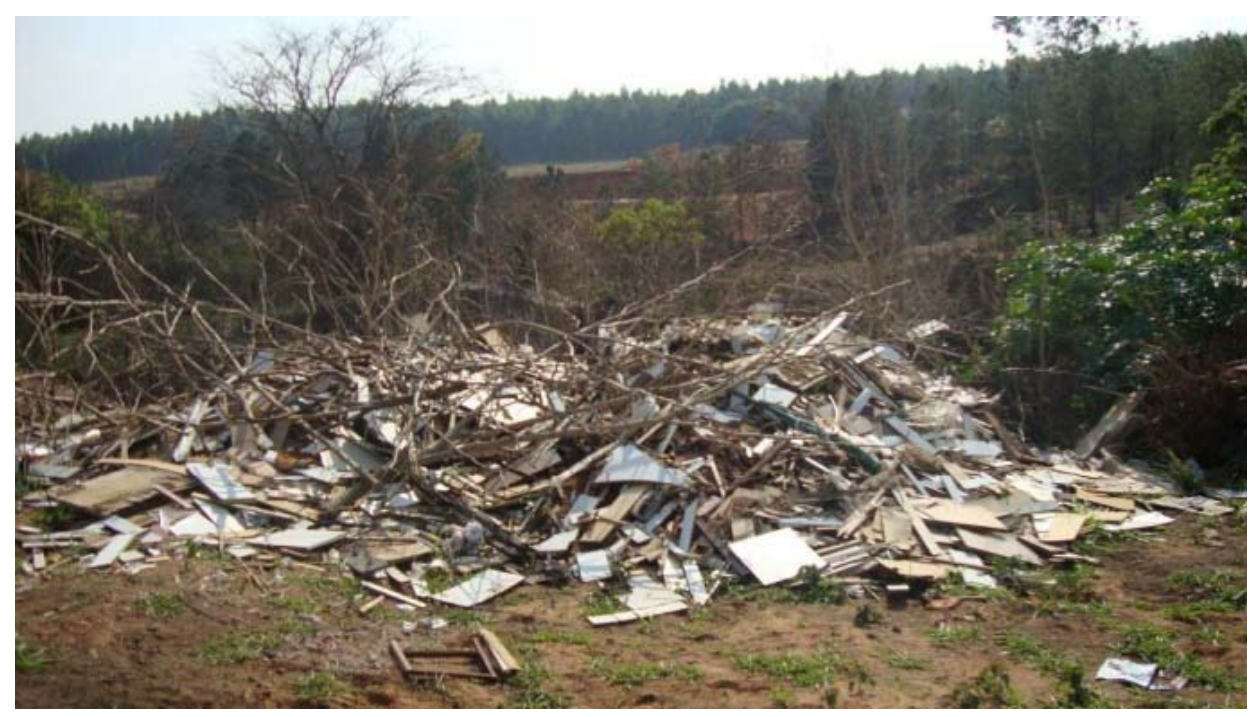

Figura 70: Entulho depositado por moradores no entorno da feição F2.

Finalmente, nas áreas R3, R6 e R7, onde se concentram as casas e vias de acesso, verificou-se pelos trabalhos de campo que o sistema de gestão das águas pluviais atua no sentido que concentram e direcionar o escoamento para áreas sem ocupação, a jusante. Em outras palavras, algumas ruas foram traçadas perpendicularmente às curvas de nível do terreno, com inclinações acentuadas, o que concentra e acelera o fluxo. Não existem estruturas coletoras ao longo das vias, apenas no final, de modo que a água de chuva que escoa superficialmente é concentrada e direcionada, por meio de canaletas, para áreas próximas à drenagem principal, onde não há ocupação, como está representado na Figura 71. 


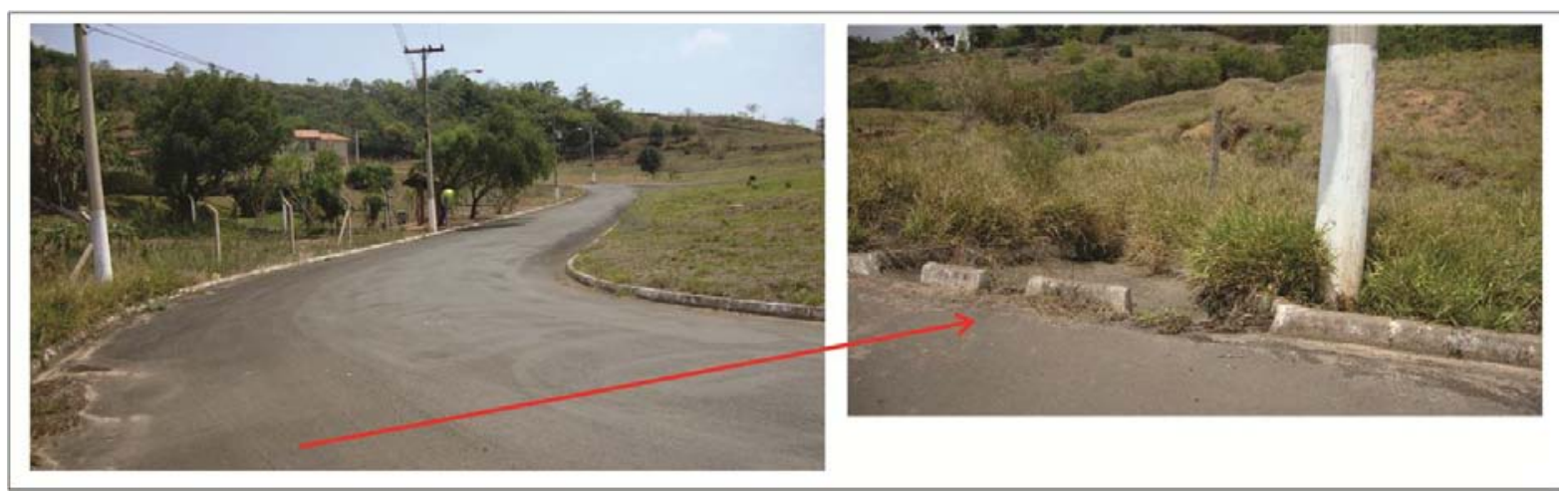

Figura 71: Via sem estruturas coletoras da água pluvial, com inclinação que favorece a concentração do escoamento, que é interceptado por uma canaleta que direciona o fluxo para uma área desocupada, próxima ao canal de drenagem.

\subsubsection{Análise da eficiência das medidas de recuperação de erosão: Área 2}

Nessa área as medidas de recuperação de erosão foram sendo modificadas de acordo com a evolução do uso e ocupação. Inicialmente, com a criação de gado, as principais medidas de controle de erosão eram a cobertura por pastagem e os cordões de nível. A primeira costuma atuar positivamente na estabilização e proteção do solo, mas é prejudicada pelo pisoteamento do gado e pelo surgimento de trilhas que concentram o fluxo. Os cordões, por sua vez, mesmo associados com a pastagem, não foram eficientes na proteção do solo dessa área, dado o elevado número de feições de grande porte que existiam no passado. Nesse contexto, pode-se citar a ausência de ações efetivas nas grandes feições como um fator de insucesso no processo de recuperação ou controle da área, dado que os cordões não são suficientes para prevenir a evolução de erosões aceleradas.

Com o tempo as iniciativas de recuperação se diferenciaram. Entre 1972 e 1988, a plantação de pinus nas áreas correspondentes às feições F1 e F6 se deu, sem ações efetivas nas feições, buscando-se apenas a contenção do processo erosivo, fornecendo maior estabilidade ao solo com a mudança de cobertura. Por outro lado, a feição F3 foi aterrada, os cordões de nível foram refeitos, no trecho superior foram plantados pinus, e no restante da área permaneceram as pastagens. Analisando a foto área de 1988 verificou-se que essas ações foram eficientes no seu conjunto, dado que o aterro eliminou as feições, e os cordões de nível permaneceram bem definidos e íntegros.

Entre os anos de 1988 e 1995, com a implantação do bairro do Jardim Botânico, várias feições foram aterradas, e cordões de nível foram feitos para garantir a integridade dos lotes. $E$ 
ainda, foi construído um sistema de drenagem no interior da feição F2, para coletar o esgoto e a água pluvial que corriam no seu interior, e que contribuíam para a sua evolução; sendo que esta foi também aterrada. $O$ aterro dessas áreas se deu utilizando o próprio solo do local, sendo que a compactação se restringiu aos lotes ocupados. $O$ indicado é que para a aplicação dessa técnica deva ocorrer uma análise do material inconsolidado a ser empregado, para avaliar se este é adequado, e para prever detalhes da execução da técnica. O aterro de áreas com fluxo subsuperficial e superficial deve envolver ainda drenos ou estruturas de macrodrenagem bem dimensionados, caso contrário o aterro pode ser novamente erodido.

No período entre 1995 e 2000 os aterros e as curvas de nível do bairro sofreram manutenção, dado que o processo erosivo não havia sido totalmente controlado. Mas de um modo geral foram observados benefícios, dado que as feições pré-existentes foram praticamente eliminadas. Por outro lado, duas situações particulares merecem destaque nesse período: em primeiro lugar, a feição F2 que havia sido canalizada e aterrada foi reativada. Esse processo se deu em decorrência do subdimensionamento das canalizações, que se romperam e liberaram o escoamento, reativando assim o processo erosivo no local. Em decorrência desse acontecimento foram plantados pinus no entorno da feição, com o objetivo de controlar o seu avanço. Mas essa medida claramente não foi suficiente, dado que não impede totalmente que o escoamento superficial alcance a feição, e se some ao escoamento de fundo, acelerando assim o processo. A segunda feição que merece destaque nesse período é a F12. Em decorrência da ocupação do bairro e da construção das vias, essa feição, que havia sido parcialmente aterrada, foi reativada. Sua reativação é consequência do traçado de uma rua, que é bastante inclinada, e que não possui estruturas coletoras de água. O que se observa ainda hoje, é que essa rua concentra o fluxo, e o despeja em uma canaleta que direciona a água para lotes vazios onde se localiza a feição F12, contribuindo diariamente para sua evolução.

No ano de 2006, não ocorreram grandes modificações no cenário de recuperação da erosão dessa área; ocorrendo apenas a intensificação da ocupação em alguns pontos. Entretanto, vale a pena resaltar que as áreas R4 e R5 não foram ocupadas por casas, permanecendo com pasto e cordões de nível. Nesse ponto verificou-se a presença de sulcos, o afloramento do substrato rochoso, e algumas falhas na cobertura vegetal, o que indicam a necessidade de manutenção das estruturas de prevenção da erosão. É interessante também ressaltar que a área R8, reflorestada por iniciativa da população permanece bastante estável.

A situação atual da área, verificada pelos trabalhos de campo, identificou apenas duas modificações nas formas de controle e recuperação da erosão no local. A primeira consiste na 
iniciativa de reflorestamento de uma área próxima a área R8, que se mostrou pouco eficiente. Foram observadas muitas mudas mortas na área, apesar de outras terem sobrevivido. $O$ ideal seria escolher espécies vegetais que melhor se adaptassem às condições naturais do local, previamente determinadas, dando preferência às espécies nativas. Outra medida observada relaciona-se a feição F2: atualmente são depositados entulhos e resíduos de poda e capina em seu interior e áreas adjacentes, mas essas atividades não afetam o desenvolvimento do processo erosivo, dado que é restrito a alguns pontos.

Um aspecto muito importante observado nessa área relaciona-se com o traçado das ruas, e com as estruturas de microdrenagem do bairro. Como foi dito, nas áreas R3, R6 e R7, as ruas concentram e aceleram o escoamento superficial, sendo que muitas foram construídas de forma inadequada, perpendicularmente ao sentido das curvas de nível do terreno. O sistema empregado na área atua coletando essa água por meio de canaletas apenas no trecho final da via, direcionando a água para áreas não ocupadas. As canaletas por sua vez também concentram e aceleram o escoamento superficial, que em períodos chuvosos pode alcançar quantidades e volumes acentuados; provocando assim erosão nessas áreas sem ocupação, ou mesmo reativando feições antigas, como o ocorreu com a feição F12. Claramente esse sistema não é adequado à realidade do local, um sistema mais completo de microdrenagem deveria ser construído no bairro, com coletores ao longo das vias, e não apenas no final, diminuindo assim o volume de água que alcança as áreas desocupadas. Outra medida simples que evitaria o surgimento de erosão a jusante das canaletas seriam a adoção de estruturas dissipadoras de energia, que conduzissem as águas do escoamento de forma disciplinada até o canal principal.

\subsubsection{Características do processo erosivo: Área 3}

O uso e ocupação da Área 3 iniciou-se com o desmatamento e recobrimento do solo por pastagens, para a criação de gado, o que contribuiu para a presença de várias estradas de terra e caminhos preferenciais, que contribuíram para a evolução da erosão nessa região. Nesse período surgiu a principal feição erosiva dessa área, que consiste em uma voçoroca de grande porte, contínua e de cabeceira, em relação ao canal de drenagem, com ramificações, que pode ser observada na Figura 72A, identificada como F1.

Por volta dos anos 70 essa área passou a ser loteada, visando a construção de pousadas, o que envolveu a preparação de lotes e o traçado de vias. Para isso algumas medidas de recuperação de erosão tiveram de ser adotadas, como o aterramento da feição F1. Nesse 
mesmo ano foi identificada a feição F2, que consistia em uma porção de solo exposto, gerada através da movimentação do solo durante o aterramento, e não uma erosão bem definida; mas que indicava a ausência de cobertura vegetal de proteção nas áreas antes ocupadas pela feição principal (Figura 72B).

Por fim, nos anos mais recentes, a ocupação da área tornou-se mais efetiva, com a construção de várias casas. Atualmente ainda existem vários lotes desocupados, e as ruas não foram recapeadas, mas a redução da feição F1 é bastante visível. Por outro lado, essa feição foi reativada, sob a forma de novas feições individuais, indicadas na Figura $72 C$ por F3, F4, F5 e F6.

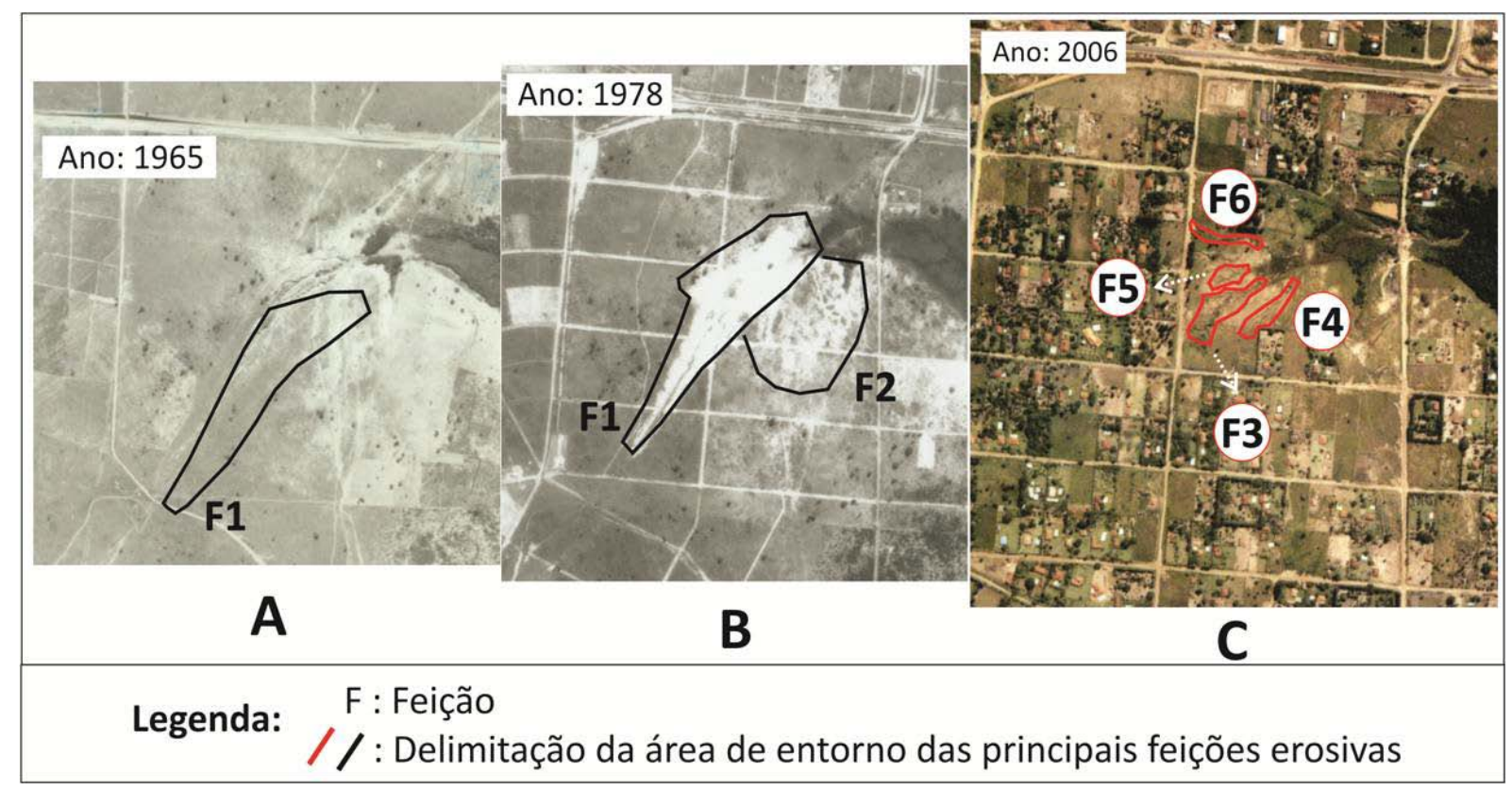

Figura 72: Principal feição erosiva da Área 3 e sua evolução ao longo do tempo.

Através dos trabalhos de campo foram identificadas as principais características geométricas das feições atuais, assim como os aspectos relacionados à sua estabilidade. Os resultados dessa análise estão indicados na Tabela 14. E ainda, na Figura 73, observa-se a superfície da Área 3, (obtida no Surfer pelo método de interpolação Radial Bases Function), e a localização das quatro feições atuais. 
Tabela 14: Caracterização das principais feições erosivas da Área 3.

\begin{tabular}{|c|c|c|c|c|}
\hline Feição & $\begin{array}{l}\text { Comprimento } \\
\text { Médio (m) }\end{array}$ & $\begin{array}{l}\text { Largura } \\
\text { Média } \\
\text { (m) }\end{array}$ & $\begin{array}{l}\text { Profundidade } \\
\text { Média (m) }\end{array}$ & Caracterização \\
\hline F3 & 150 & 10 & 1 a 2 & $\begin{array}{l}\text { Reativação da feição original, com muitas } \\
\text { ramificações. Porém a evolução da feição } \\
\text { ainda não provocou a conexão da mesma } \\
\text { com a drenagem, de modo que, } \\
\text { atualmente, essa feição pode ser } \\
\text { caracterizada por descontínua de } \\
\text { encosta. Em alguns pontos as paredes } \\
\text { indicam atividade, embora o fundo esteja } \\
\text { estável. Por outro lado, essa feição } \\
\text { apresenta potencial de evolução nos } \\
\text { períodos chuvosos. }\end{array}$ \\
\hline F4 & 150 & até 40 & Menor que 1 & $\begin{array}{l}\text { Reativação de uma ramificação da feição } \\
\text { original. Apresenta-se consideravelmente } \\
\text { estável, com formado em "U" e fundo } \\
\text { bastante vegetado. Porém, pode evoluir } \\
\text { facilmente nos períodos chuvosos. Não } \\
\text { apresenta conectividade com a } \\
\text { drenagem, dada a ação do aterramento. }\end{array}$ \\
\hline F5 & 50 & 10 & 1 a 2 & $\begin{array}{l}\text { Reativação da feição original, com } \\
\text { indícios de que pode evoluir nos períodos } \\
\text { chuvosos, e também sem conectividade } \\
\text { com a drenagem, dada a ação do } \\
\text { aterramento. Consiste assim em uma } \\
\text { feição descontínua de encosta. }\end{array}$ \\
\hline F6 & 70 & 10 & até 4 & $\begin{array}{c}\text { É a feição mais evoluída atualmente, } \\
\text { possuindo conectividade com a } \\
\text { drenagem, sendo assim uma feição } \\
\text { contínua de cabeceira. Apresenta sulcos e } \\
\text { ângulos negativos em suas paredes, } \\
\text { indicando que o processo erosivo está } \\
\text { ativo, podendo evoluir muito nos } \\
\text { períodos chuvosos. }\end{array}$ \\
\hline
\end{tabular}




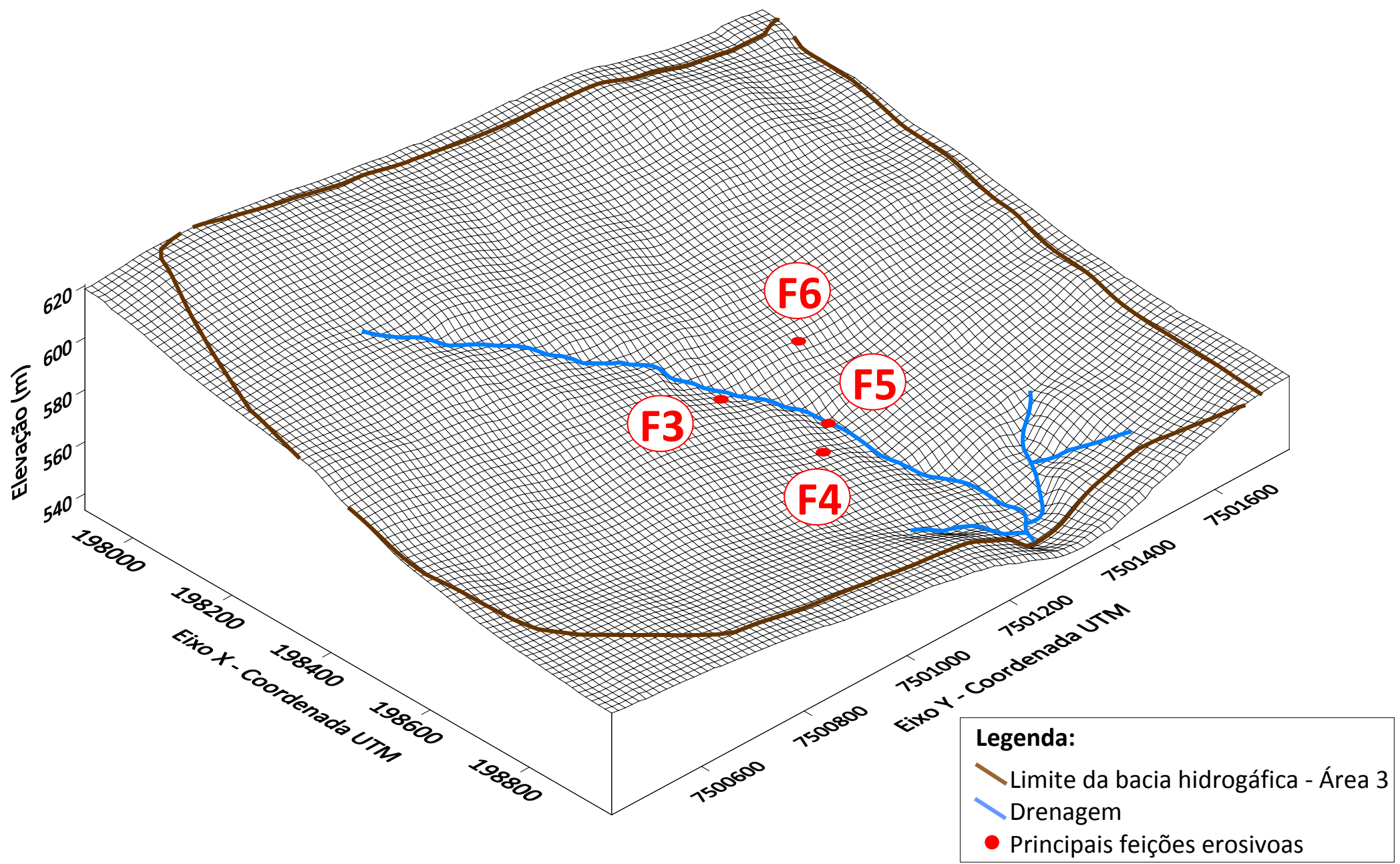

Figura 73: Superfície 3D representativa da Área 3, com localização das principais feições erosivas. 
Nas Figuras 74, 75 e 76 podem-se observar as condições atuais das feições F6, F3 e F5, respectivamente. É possível verificar que as feições F3 e F6 apresentam ramificações, sendo a segunda mais ativa; e ainda, pela observação da feição F4, que está menos evoluída que as demais, fica bastante claro o processo de aterramento nessa área.

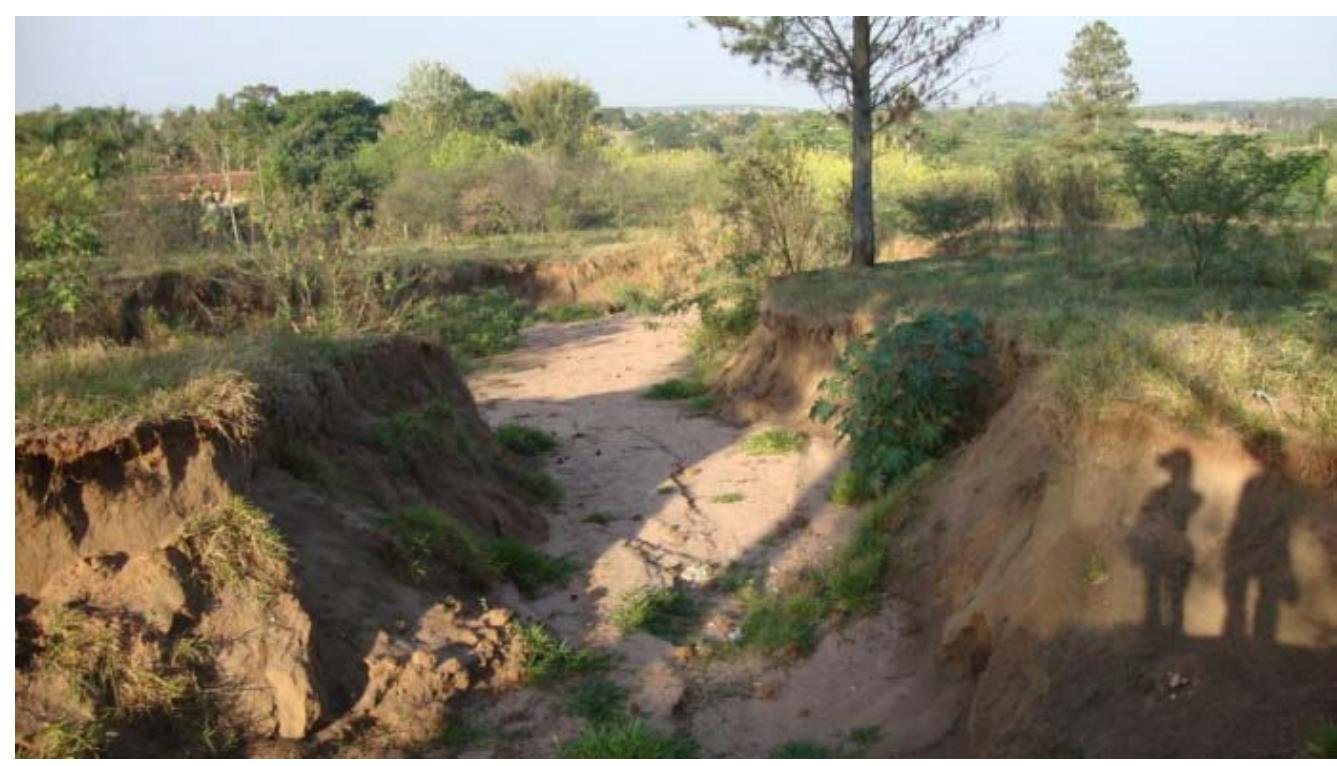

Figura 74: Feição F6, bastante ativa, e com ramificações.

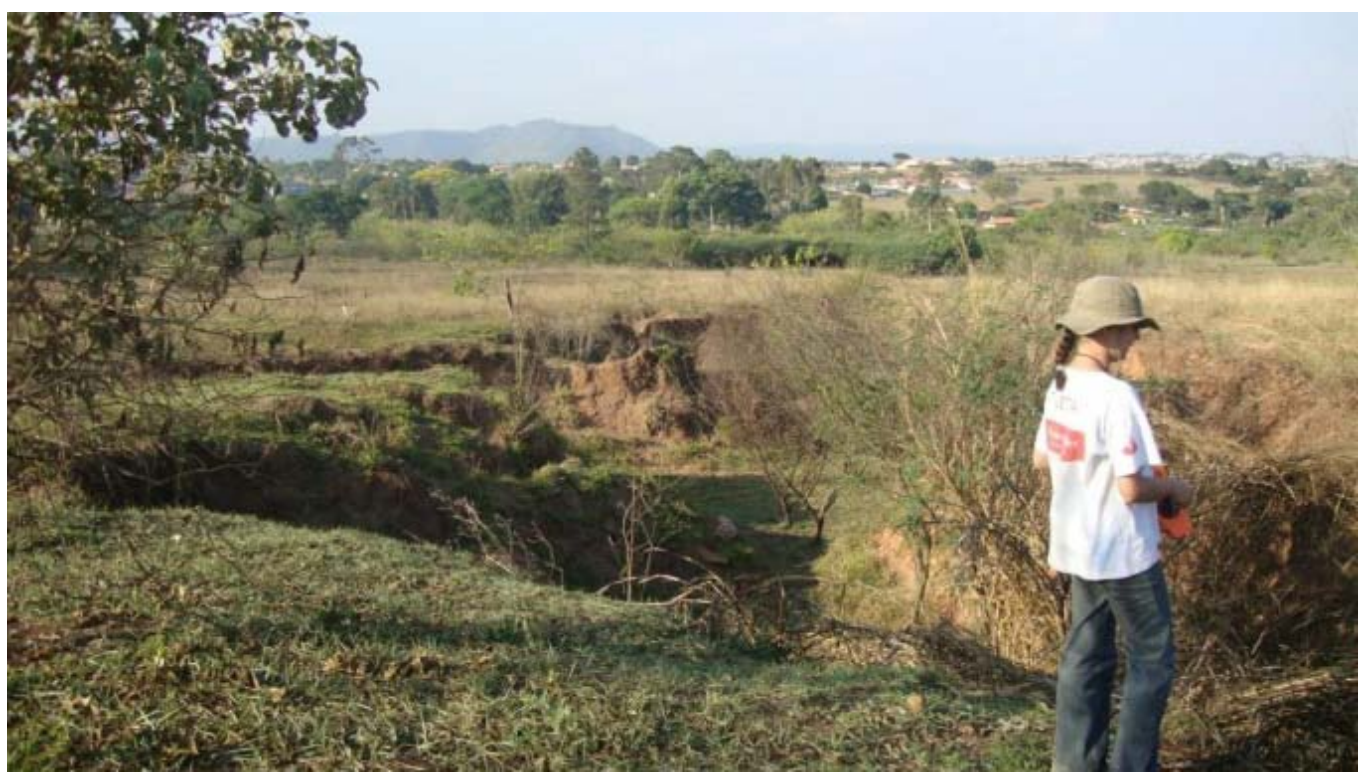

Figura 75: Feição F3, com potencial para evolução. 


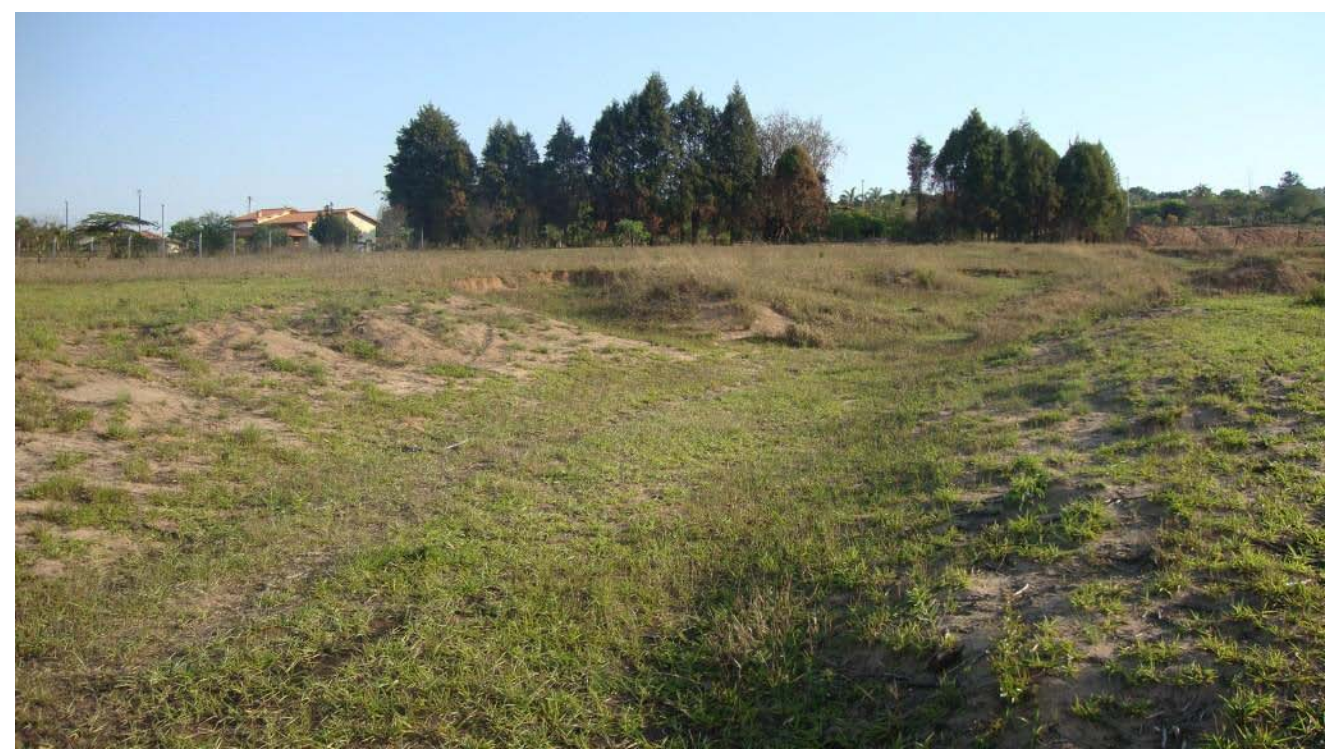

Figura 76: Feição F4, pouco evoluída, mas com potencial para aceleração dos processos erosivos nos períodos chuvosos.

\subsubsection{Descrição das medidas de recuperação: Área 3}

O processo de recuperação da erosão na Área 3, como foi citado anteriormente, se baseou no aterramento da feição F1. Observando-se a Figura 72B, vê-se que a feição principal F1 abrangia cerca de 8 quadras, sendo o seu aterro crucial para a ocupação urbana. No trecho mais próximo ao canal de drenagem, onde hoje estão localizadas as feições F3, F4, F5 e F6 (Figura 72C) também houve aterramento, mas o processo erosivo foi reativado. Além do aterro, nas quadras em que as feição foram reativadas há cobertura vegetal de gramíneas, que possui um papel importante na proteção do solo contra a ação do escoamento superficial. E ainda, foi verificado que ao redor da quadra onde as feições se localizam foi feita uma espécie de barreira de proteção, com o próprio solo do local, objetivando diminuir o volume do escoamento superficial que chega até as feições, retardando sua evolução, como está representado na Figura 77. 


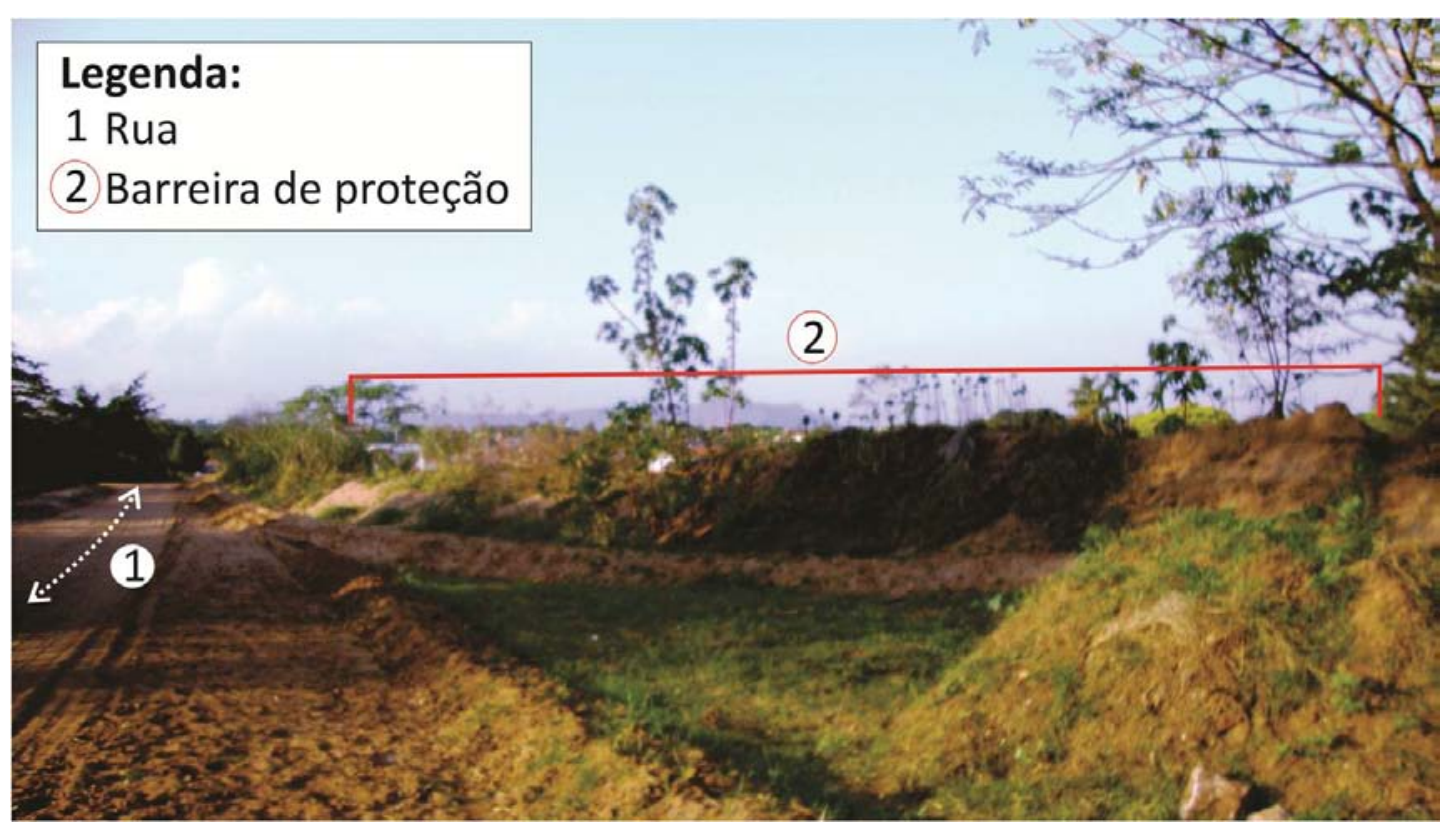

Figura 77: Barreira de proteção na forma de elevações de solo, dispostas ao redor da área, onde estão localizadas as feições erosivas da Área 3.

\subsubsection{Análise da eficiência das medidas de recuperação de erosão: Área 3}

Por análise da Figura 72 pode-se observar que o aterro da feição F1 foi fundamental para a implantação do loteamento nessa área. Das oito quadras atingidas pela feição F1, seis não apresentam sinais de processo erosivo ativo, conforme se vê na Figura $72 \mathrm{C}$, indicando uma eficiência do aterramento. Por outro lado, analisando a mesma Figura, em duas quadras a erosão ainda permanece. Por trabalhos de campo constatou-se que essa área também foi aterrada, porém não de forma eficiente, de modo que o processo erosivo foi reativado, levando ao surgimento das novas feições. Verificou-se também que para o aterro foi utilizado o solo do próprio local, sem a compactação necessária. Como foi dito anteriormente, o aterro de uma área deve envolver a análise do material inconsolidado a ser empregado, para avaliar se este é adequado, e para prever detalhes da execução. Dada a presença de fluxo subsuperficial e superficial no local, essa medida deveria envolver ainda a presença de drenos ou estruturas de macrodrenagem, de modo a evitar a reativação da erosão.

A cobertura vegetal de gramíneas, assim como a barreira de proteção que contorna a quadra, adotadas em conjunto com o aterramento, mostrou-se insuficientes na diminuição do volume de escoamento superficial para proteger a área, que é bastante suscetível aos processos erosivos. No caso das gramíneas, é necessário que haja manutenção da mesma, buscando evitar 
o surgimento de falhas, que favorecem o processo erosivo. Já a barreira em torno da quadra, não é suficiente para impedir todo o escoamento atinja as feições.

Verificou-se ainda que não existe nenhum tipo de estrutura de microdrenagem nessa área. Dado o uso urbano do local, e as condições de evolução da erosão verificadas, esse tipo de estrutura é essencial. Para sua adoção, devem ser realizados os estudos estruturais e hidrológicos necessários à escolha adequada das estruturas a serem usadas, e ainda o dimensionamento e construção das mesmas.

\section{3. Área 4}

\subsubsection{Características Básicas}

A Área 4 insere-se na zona geomorfológica da Depressão Periférica, em duas bacias hidrográficas de segunda ordem, cujas altitudes variam entre 580 e 664 metros, conforme foi apresentado na Figura 41. Em relação aos materiais inconsolidados, observando-se a mesma figura vê-se que nessa área são encontrados os residuais da Formação Botucatu, podendo ocorrer também os Retrabalhados Arenosos.

Os materiais inconsolidados Residuais da Formação Botucatu foram caracterizados química e fisicamente por Fernandes (2003). A autora indica que esses materiais são arenosos, com valor de massa específica dos sólidos $\left(\rho_{\mathrm{s}}\right)$ em torno de $2,73 \mathrm{~g} / \mathrm{cm} 3$; e que apresentam baixa erodibilidade, de acordo com os resultados obtidos nos ensaios de absorção de água e perda de massa. Os resultados obtidos pela autora estão indicados nas Tabelas 15 e 16. 
Tabela 15: Caracterização química e física dos materiais inconsolidados Retrabalhados Areno-siltosos (FERNANDES, 2003).

\begin{tabular}{|c|c|c|}
\hline & & Residuais da F. Botucatu \\
\hline & & Amostra 10 \\
\hline \multirow{4}{*}{$\begin{array}{l}\text { Ensaio Azul de } \\
\text { Metileno }\end{array}$} & CTC & 2,18 \\
\hline & SE & 17,29 \\
\hline & Vb & 0,71 \\
\hline & Acb & 2,31 \\
\hline \multirow{3}{*}{$\begin{array}{c}\text { Granulometria } \\
\text { com Defloculante } \\
(\%)\end{array}$} & Areia & 68 \\
\hline & Silte & 10 \\
\hline & Argila & 22 \\
\hline \multirow{3}{*}{$\begin{array}{c}\text { Granulometria } \\
\text { sem Defloculante }\end{array}$} & Areia & 74 \\
\hline & Silte & 26 \\
\hline & Argila & 0 \\
\hline \multirow{5}{*}{ Índices Físicos } & $\rho s(\mathrm{~g} / \mathrm{cm} 3)$ & 2,73 \\
\hline & $\rho(\mathrm{g} / \mathrm{cm} 3)$ & 1,87 \\
\hline & $\rho d(g / c m 3)$ & 1,7 \\
\hline & e & 0,61 \\
\hline & n (\%) & 37,73 \\
\hline
\end{tabular}

Tabela 16: Erodibilidade dos materiais inconsolidados Retrabalhados Areno-siltosos, obtidos pelos métodos de PEJON (1992), e de NOGAMI e VILLIBOR (1979) (FERNANDES, 2003).

\begin{tabular}{|c|c|c|}
\cline { 2 - 3 } \multicolumn{1}{c|}{} & \multicolumn{2}{c|}{ Residuais da F. Botucatu } \\
\cline { 2 - 3 } \multicolumn{1}{c|}{} & $\begin{array}{c}\text { Erodibilidade - } \\
\text { PEJON (1992) }\end{array}$ & $\begin{array}{c}\text { Erodibilidade - Nogami } \\
\text { \& Villibor (1979) }\end{array}$ \\
\hline Amostra 10A & 11,11 & 14,45 \\
\hline Amostra 10B & 10,41 & 13,54 \\
\hline Amostra 30A & 10,03 & 13,04 \\
\hline Amostra 30B & 8,62 & 11,20 \\
\hline
\end{tabular}

Os materiais inconsolidados Retrabalhados Arenosos, por sua vez, já foram caracterizados anteriormente na descrição física das Áreas 2 e 3.

\subsubsection{Caracterização do processo erosivo}

A Área 4 teve seu processo erosivo acelerado pelo desmatamento, para posterior implantação de pastagens, uma vez que a alteração do tipo de cobertura vegetal facilitou a ação do escoamento superficial, em pontos próximos aos canais de drenagem, levando ao surgimento de voçorocas de grande porte. Os grupos de feições existentes nessa área estão representados 
nas Figuras 78 e 79. Com o tempo a pastagem foi substituída pela plantação de eucalipto, com finalidade comercial, sendo essa a configuração atual da área (Figura 79). Apesar da mudança no uso e ocupação as feições permaneceram sem grandes alterações.

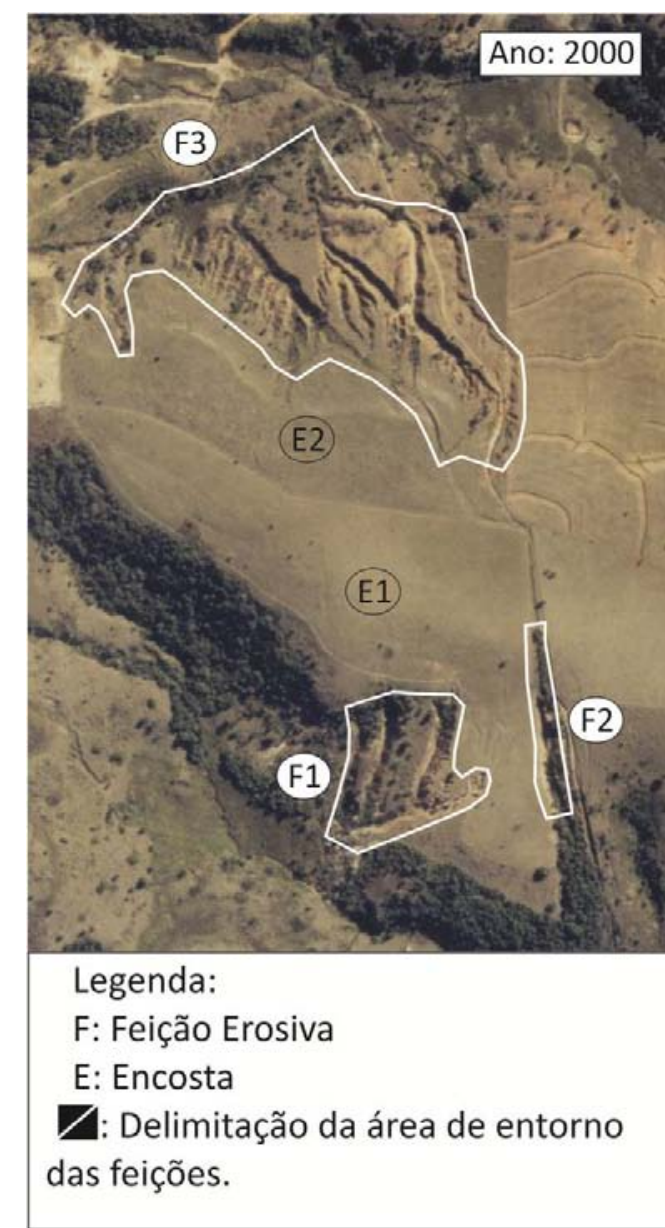

Figura 78: Delimitação das principais feições erosivas da Área 4, com detalhe para o ocupação da área por pastagens.

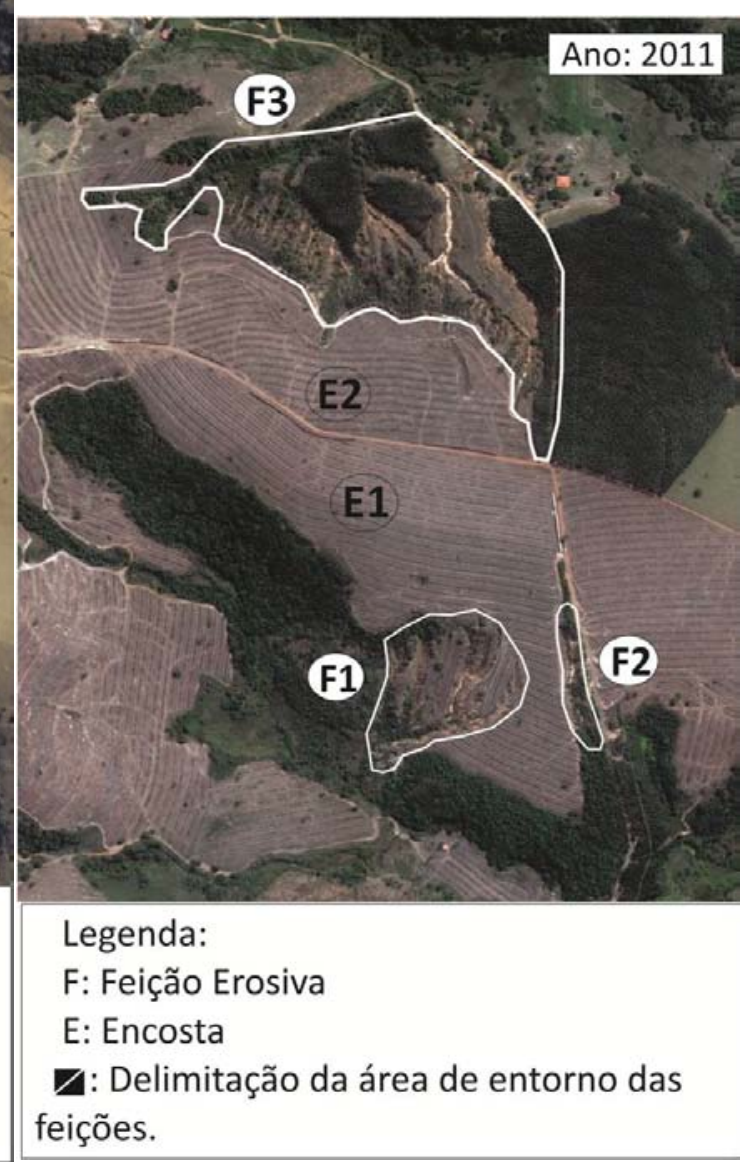

Figura 79: Delimitação das principais feições erosivas da Área 4, com detalhe para o ocupação da párea por plantação de eucalipto.

Através dos trabalhos de campo foi possível verificar as características geométricas e as condições de estabilidade das três feições erosivas dessa área, sumarizadas na Tabela 17. E também foram geradas as superfícies representativas das duas bacias que compreendem a Área 3, nas quais foram localizadas as três voçorocas principais. Na Figura 80 tem-se a bacia que compreende as feição F1 e F2, gerada pelo método de interpolação Kriging, e na Figura 81, encontra-se a bacia hidrográfica que compreende a feição F3, gerada pelo método Radial Bases Function. 
Tabela 17: Caracterização das principais feições erosivas encontradas na Área 4.

\begin{tabular}{|c|c|c|c|c|}
\hline Feição & $\begin{array}{c}\text { Comprimento } \\
\text { médio (m) }\end{array}$ & $\begin{array}{c}\text { Largura } \\
\text { média (m) }\end{array}$ & $\begin{array}{c}\text { Profundidade } \\
\text { média (m) }\end{array}$ & $\begin{array}{c}\text { Caracterização } \\
\text { F1 }\end{array}$ \\
\hline F2 & 100 & 100 & 50 & $\begin{array}{c}\text { Feição com ramificações; bastante } \\
\text { ativa, com formado em "V", } \\
\text { presença de água no fundo, paredes } \\
\text { com sulcos e desmoronamentos; e } \\
\text { pouca vegetação no interior. } \\
\text { Compreende uma feição contínua } \\
\text { de cabeceira. }\end{array}$ \\
\hline F3 & 30 & 50 & $\begin{array}{c}\text { Feição descontínua de cabeceira, } \\
\text { com indicações de atividade do } \\
\text { processo erosivo, sobretudo nas } \\
\text { paredes. Sem água no interior, e } \\
\text { com potencial para evolução, } \\
\text { sobretudo nos períodos chuvosos. }\end{array}$ \\
\hline 200 & 200 & 40 a 50 & $\begin{array}{c}\text { Feição bastante ramificada, contínua } \\
\text { de cabeceira, com formato em "V", } \\
\text { sem a presença de água próximo à } \\
\text { cabeceira. Apresenta vegetação de } \\
\text { pequeno porte no interior, mas há } \\
\text { indícios de evolução do processo } \\
\text { nos períodos chuvosos, sobretudo } \\
\text { nas paredes. }\end{array}$ \\
\hline
\end{tabular}




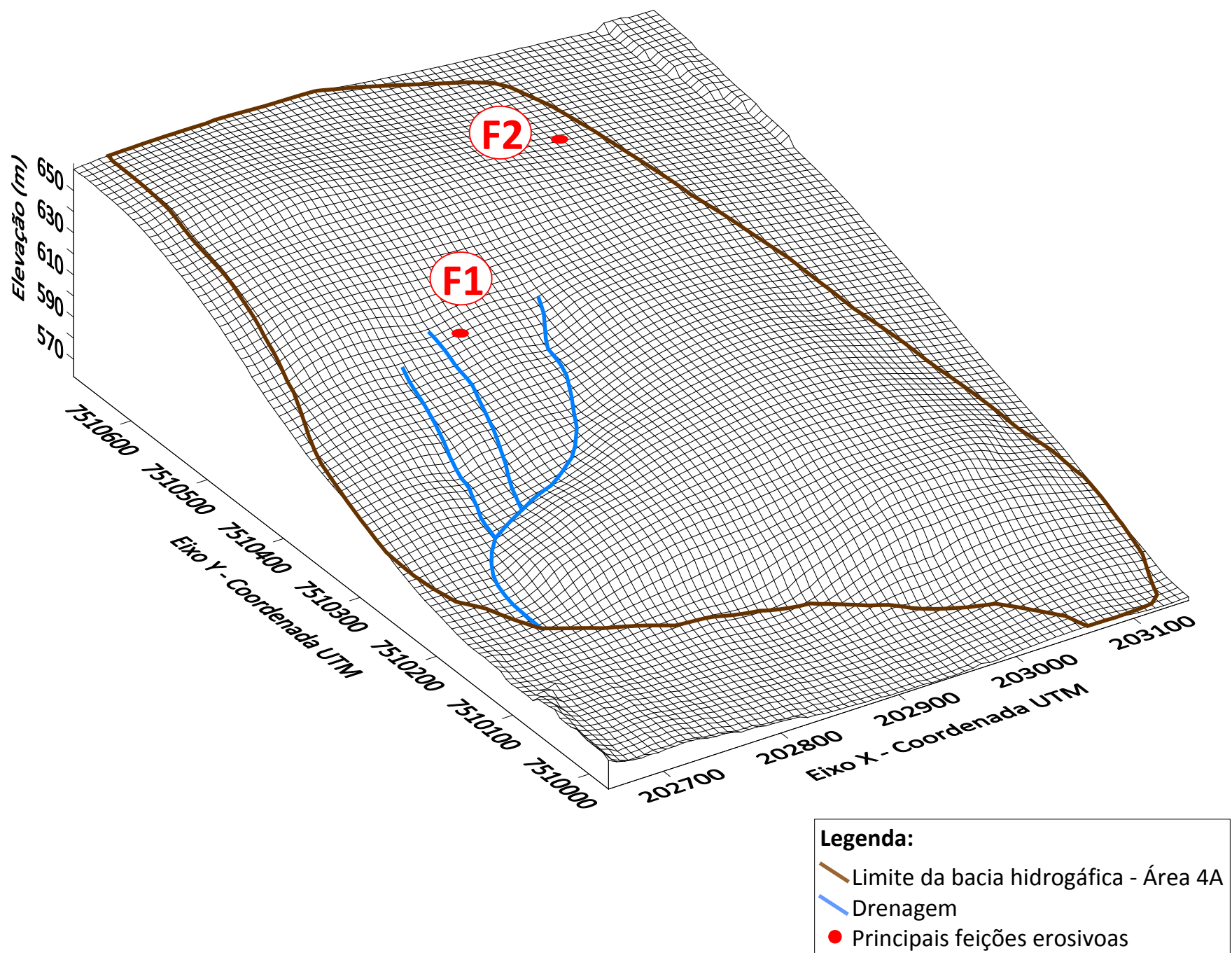

Figura 80: Superfície 3D representativa de uma das bacias hidrográficas que compreendem a Área 4, com localização das principais feições erosivas. 


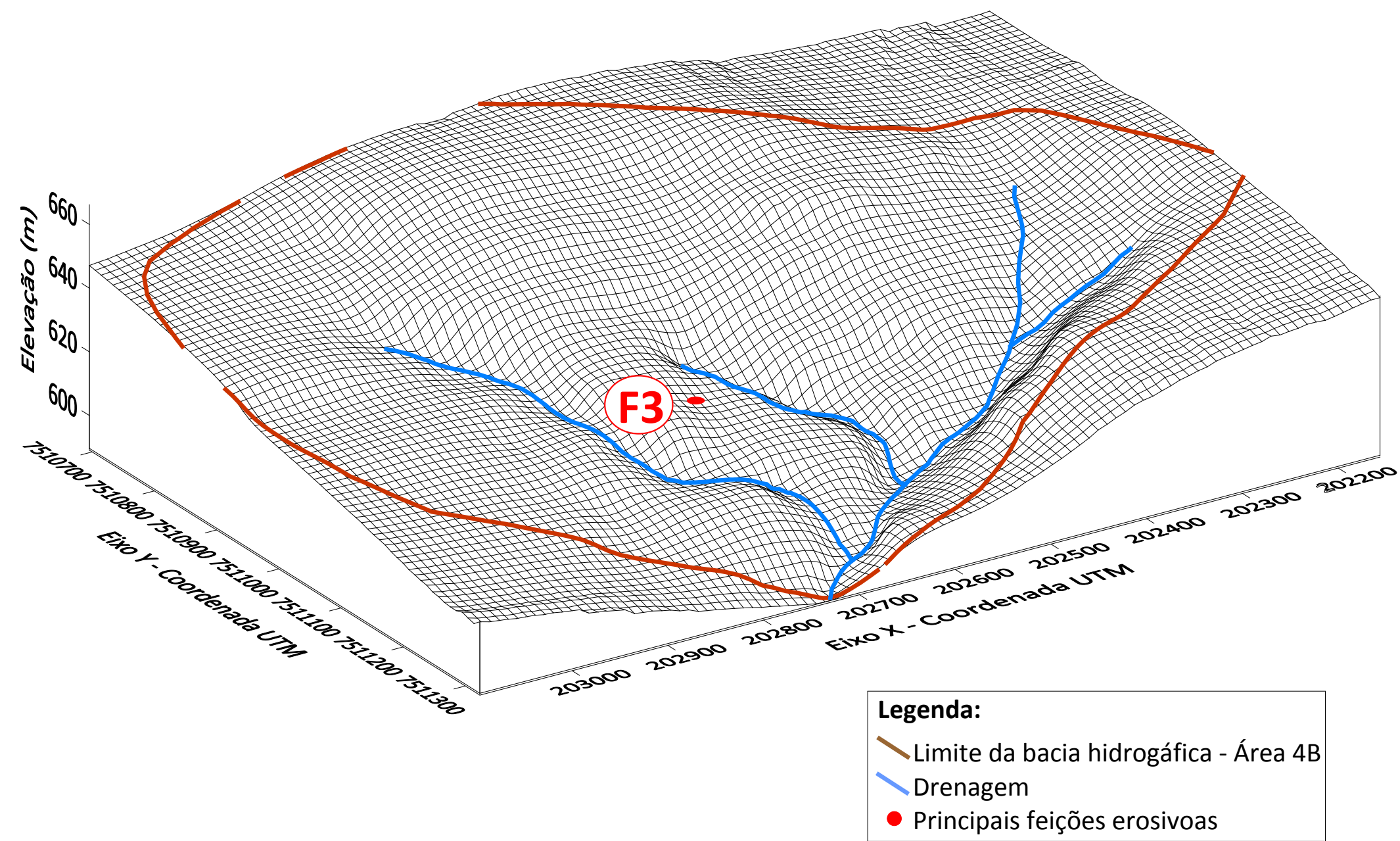

Figura 81: Superfície 3D representativa de uma das bacias hidrográficas que compreendem a Área 4, com localização das principais feições erosivas. 
Duas ramificações da feição F1 estão representadas pelas Figuras 82 e 83, através das quais se pode visualizar como o processo erosivo nessa feição é bastante ativo. Em sequência, na Figura 84, tem-se a feição F2. E nas Figuras 85 e 86, ramificações da feição F3.

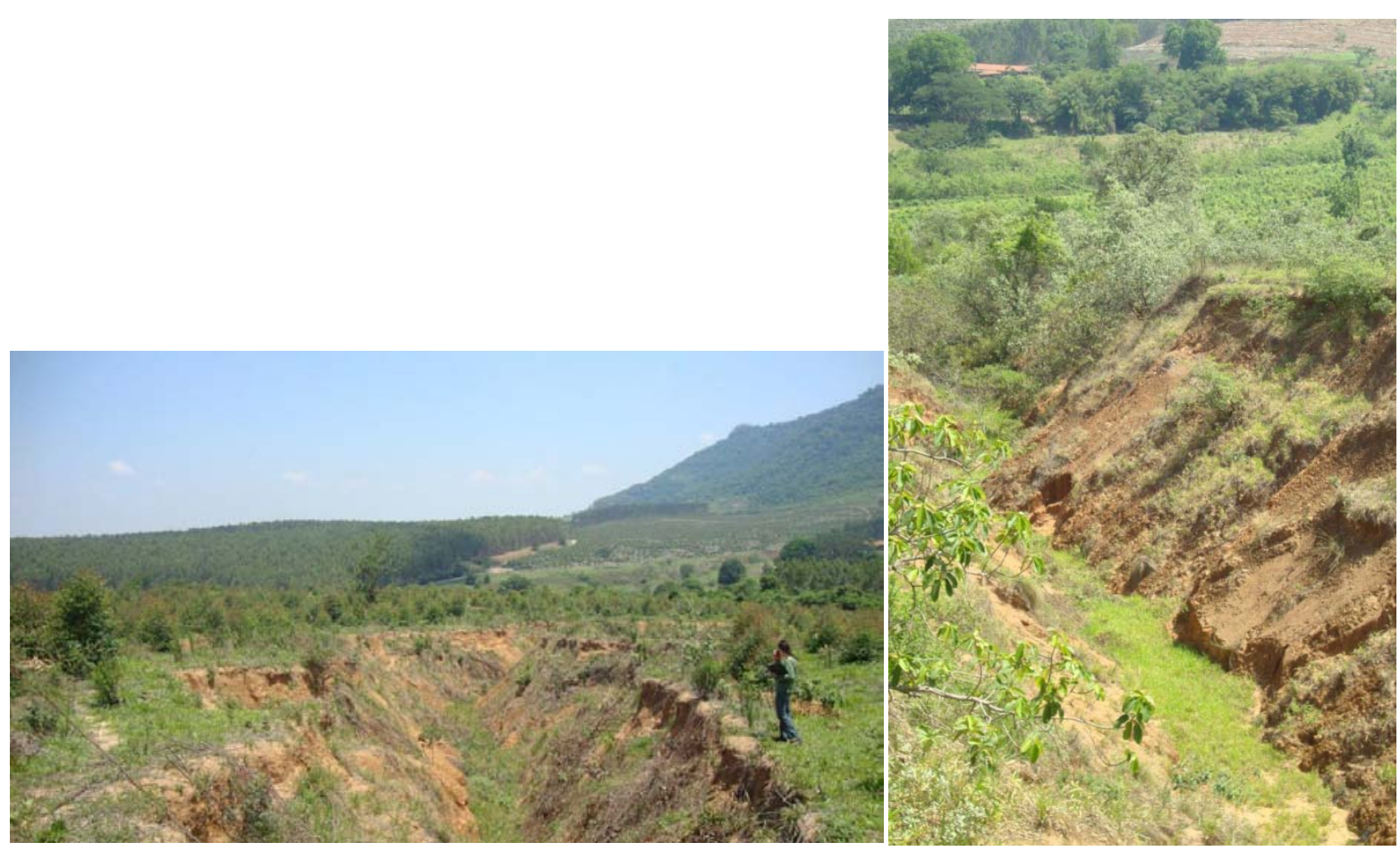

Figura 82: Ramificação da feição F1.

Figura 83: Ramificação da F1 com presença de água no interior.

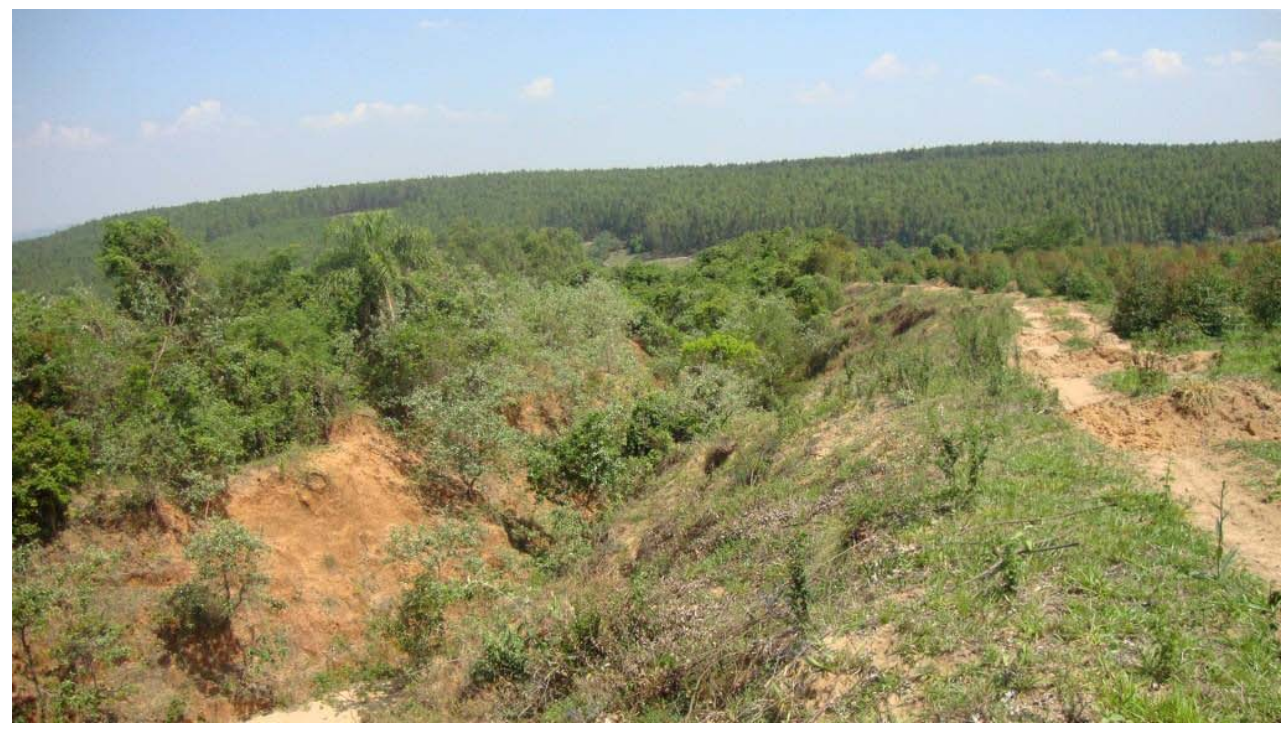

Figura 84: Feição F2, com a presença de vegetação no interior. 


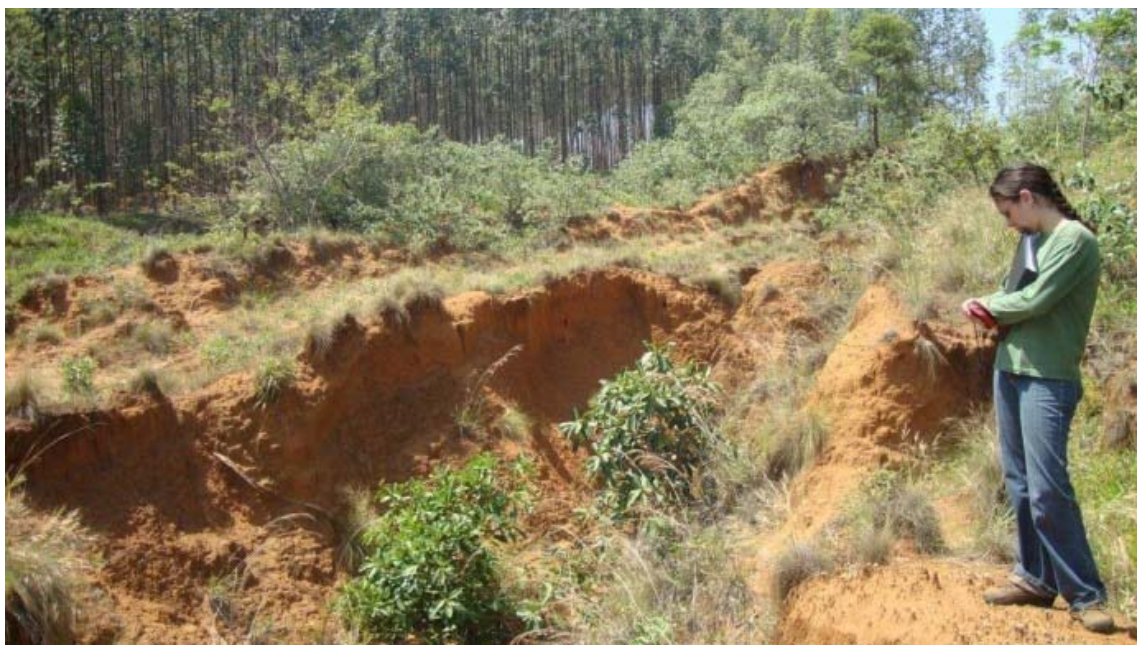

Figura 85: Ramificação da feição F3, com a presença de seixos.

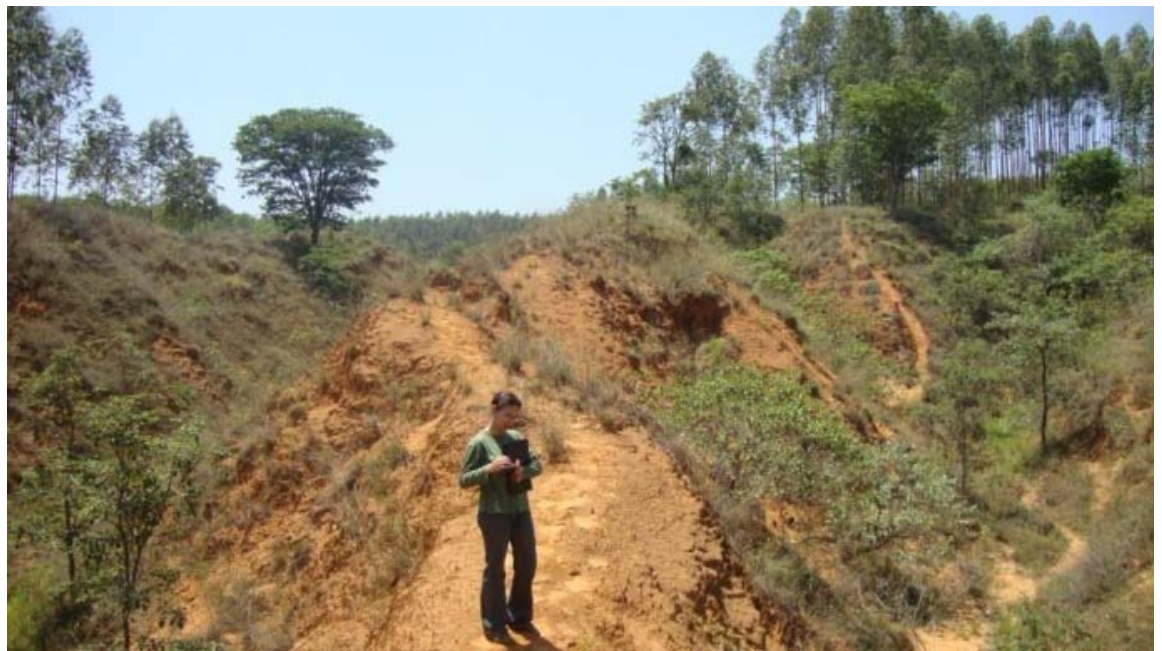

Figura 86: Ramificações da feição F3.

\subsubsection{Descrição das medidas de recuperação}

Analisando as Figuras 78 e 79 verifica-se que as áreas de entorno das feições, no passado, eram ocupadas por pasto, com a presença de alguns cordões de nível; entretanto, por volta do ano 2005, o uso do solo foi alterado, de modo que a pastagem foi substituída por plantação de eucalipto, com finalidade comercial. Para evitar que o escoamento superficial atuasse de modo a acelerar os processos erosivos já intensos na área, foi adotada uma medida de controle da erosão nessas encostas, denominada brush barrier ou barreira de galhos. Essa medida consiste em colocar ramos secos ou resíduos de galhos e casca de árvore entre as fileiras de eucalipto, para barrar o escoamento superficial, diminuindo sua velocidade; e aumentando a 
infiltração (Figuras 87 e 88). Por outro lado, não foram observadas medidas que atuassem no sentido de recuperar as grandes voçorocas da área, em nenhum período. Observou-se apenas, que algumas árvores de eucalipto, próximas a essas feições, não foram cortadas, ou seja, foram dispostas na tentativa de colaborar com o controle do processo erosivo na área.

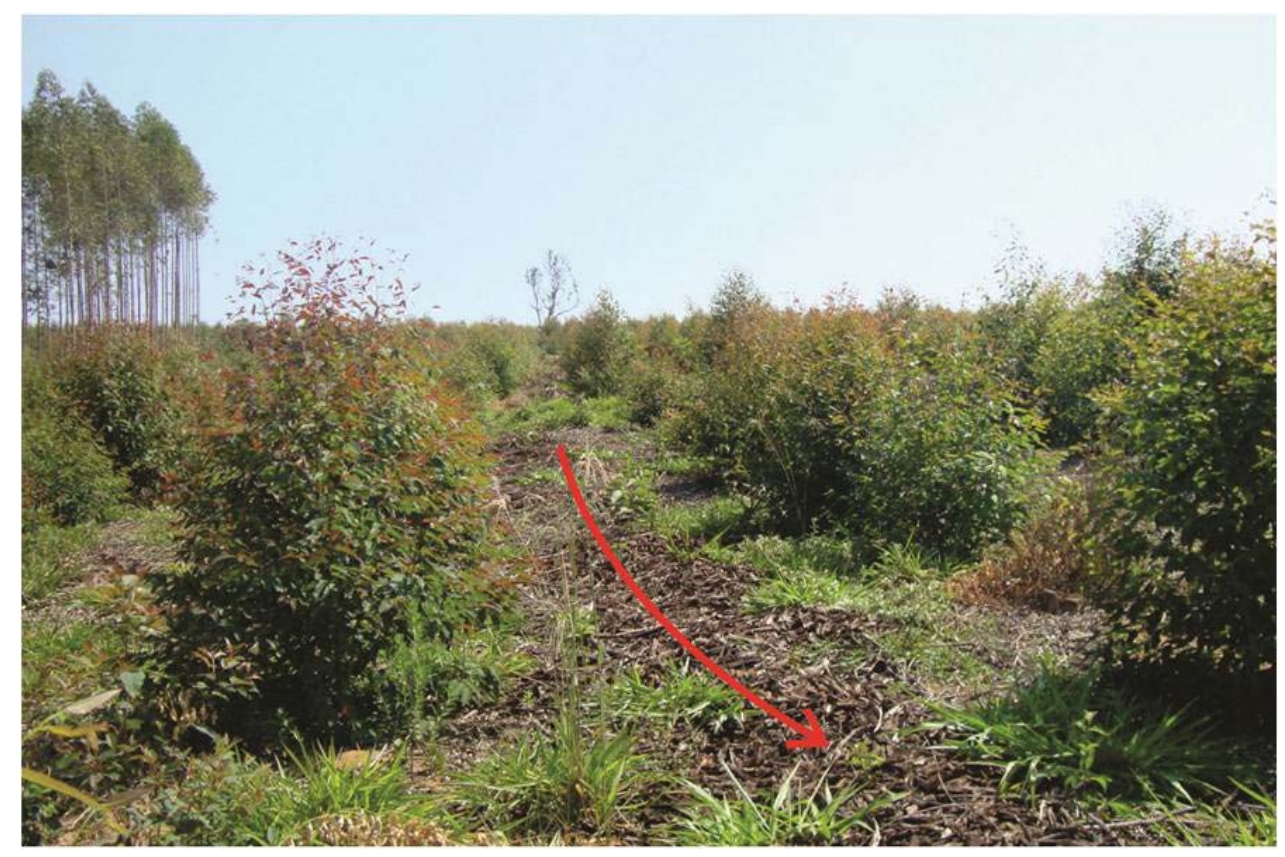

Figura 87: Resíduos de galho e cascas de madeira dispostos entre as fileiras de eucalipto. 


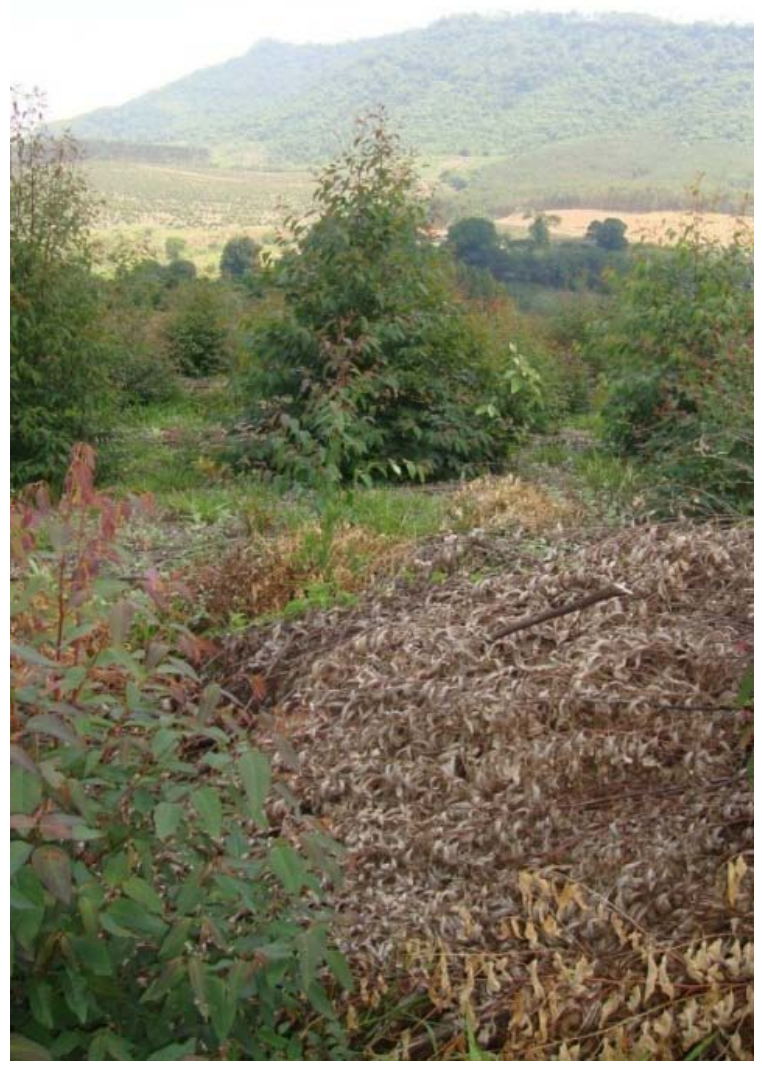

Figura 88: Galhos e folhagem secos dispostos entre as fileiras de eucalipto.

Em torno na feição F2 foi empregada outra medida de controle de erosão, que consiste em várias depressões no solo, feitas por máquina agrícola, ao longo da margem da feição, conforme pode ser observado na Figura 89. Essa medida visa barrar o escoamento superficial, fazendo-o acumular, e consequentemente, aumentar a infiltração, diminuindo assim o volume e a velocidade de água que alcança a feição. 


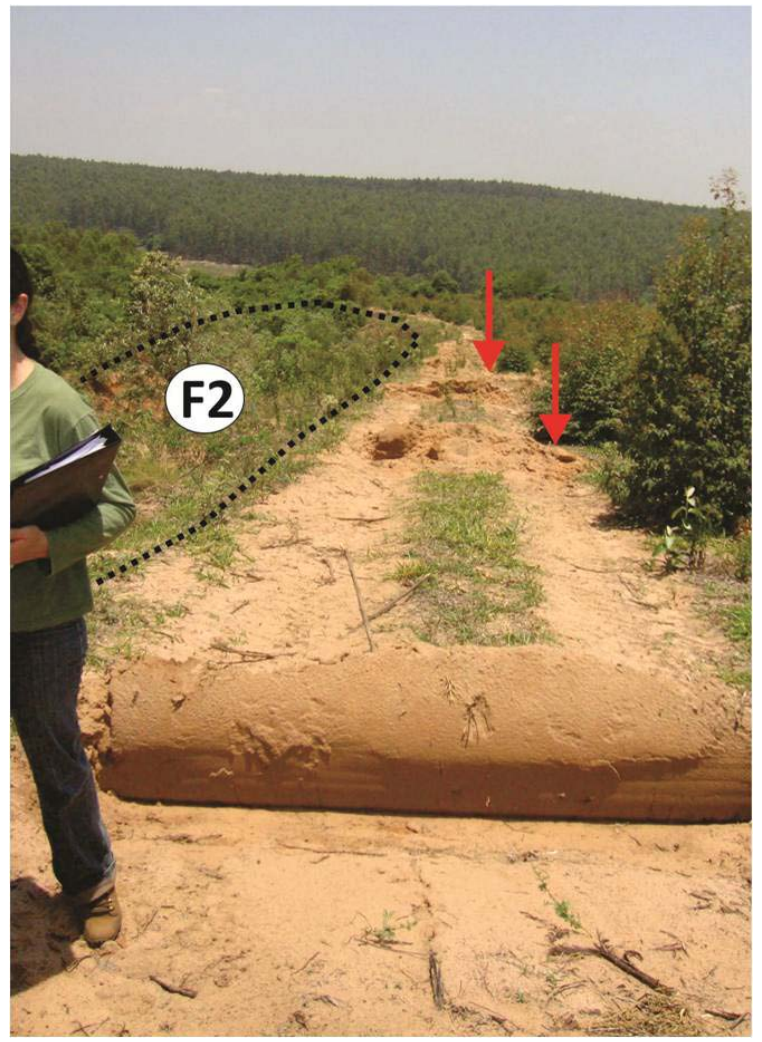

Figura 89: Depressões no solo, na lateral da feição F2, para interceptação e diminuição do escoamento superficial, por meio do aumento da infiltração.

\subsubsection{Análise da eficiência das medidas de recuperação de erosão}

Nessa área a pastagem foi insuficiente para evitar o processo erosivo acelerado, indicando a falta de melhores práticas de conservação e manejo (como o ressemeio periódico, o controle do número de animais por área, o rodízio de pastagem, o uso de fertilizantes, etc); o que justificou a adoção de cordões de nível como medida complementar nas encostas. Porém, observando-se a Figura 78 percebe-se que estas estruturas não apresentam um distanciamento regular, indicando a falta de critérios técnicos em sua construção. De modo geral, a ausência de sulcos ou ravinas nas encostas indica que os cordões foram eficientes em sua proteção, mas o mesmo não ocorreu em relação ao controle da evolução das feições de grande porte, indicando a necessidade de se cumprir às determinações de dimensionamento e espaçamento.

A mudança de pastagem para eucalipto foi acompanhada de uma maior preocupação com a manutenção da área cultivável, justificando o interesse em controlar o avanço da erosão nessa área, por meio da adoção da técnica de barreira de galhos (brush barrier). Através dos trabalhos de campo constatou-se que essa medida é eficiente na proteção das encostas, uma vez que não foram observados processos erosivos de nenhuma magnitude nesses trechos. Já no 
que se refere ao controle da evolução das feições de grande porte, a atuação dessa medida não é definitiva, pois sozinha não alcança resultados promissores, dado que as feições apresentam grande atividade de fundo, e instabilidade das paredes. Estruturalmente, as barreiras foram intercaladas com as fileiras de eucalipto, de modo que a área de captação relativa a essa medida é muito menor do que o limite determinado; assim como o comprimento de encosta a montante. Por outro lado, as dimensões das barreiras estão menores que as recomendadas, o que é compensado pelo número excessivo dessa técnica, dispostos no local. Caso haja material disponível é recomendável que as barreiras sejam aumentadas.

A utilização de caixas ou depressões de sedimentação associadas à feição F2, feitas por incisões no solo, por meio de máquinas agrícolas, não envolveu planejamento. As incisões não são muito profundas (cerca de $20 \mathrm{~cm}$ ), de modo que, em períodos de muita chuva, pode ocorrer o transbordamento, e o surgimento de um escoamento concentrado em outra direção. Por outro lado, em situações de chuvas regulares, essa medida pode contribuir para a diminuição do volume e da velocidade do escoamento que atinge a feição. Entretanto, a feição F2 apresenta atividade em suas paredes e fundo, de modo que essa técnica não é suficiente para controlar o processo. A aplicação correta dessa medida deve ainda envolver cálculos hidrológicos, com a determinação da vazão, e da área de captação de cada depressão, de modo a se obter as dimensões ideias da estrutura. É necessária ainda a manutenção da medida, pois o assoreamento da mesma pode prejudicar a sua função.

Vale destacar ainda o papel do eucalipto utilizado na revegetação dessa área. Essa espécie vegetal é bastante resistente, e se desenvolve bem em solos pobres e secos, mas sua adoção não deve descartar estudos das condições físicas do local. Por outro lado, dada a finalidade comercial, a floresta é constantemente derrubada e replantada, de modo que a manutenção deve ser intensa nos primeiros estágios de crescimento, e técnicas complementares de proteção do solo devem ser utilizadas. E ainda, apesar de interessante, a iniciativa de deixar árvores próximas às grandes voçorocas sem serem cortadas não é suficiente para atuar no controle das grandes feições.

\subsection{Análise Geral}

Em termos geotécnicos as áreas estudadas são constituídas predominantemente por materiais inconsolidados arenosos, com mais de $60 \%$ de areia, com baixos valores coesão 
(próximo a zero) e altos níveis de erodibilidade. De maneira geral, verificou-se que todas as medidas de recuperação implantadas nas áreas não levaram em consideração, tanto no projeto, quanto na implantação, às características geotécnicas, tais como: gênese dos materiais inconsolidados, aspectos granulométricos, características de compactação (peso especifico seco máximo e umidade ótima), taxa de infiltração potencial, resistência ao cisalhamento, profundidade, comprimento das encostas, declividade, volume de água acumulado nas encostas e modificações provocadas pelos usos. Também não foram considerados aspectos relacionados ao regime de chuvas, que afetam diretamente o comportamento dos materiais, a escolha e o planejamento das medidas de recuperação. Como consequência, em todas as áreas, as medidas adotadas não foram eficientes na prevenção e no controle dos processos erosivos.

$\mathrm{Na}$ Área 1 os esforços se concentraram em proteger as encostas, visando à retomada do processo de loteamento, o que determinou a ausência de qualquer medida efetiva no controle ou na recuperação das feições de grande porte, próximas à drenagem. Verificou-se nesse caso que as técnicas aplicadas foram mal dimensionadas, mostrando-se insuficientes, e até mesmo agravantes no controle da erosão. A manutenção da área, visando à futura ocupação urbana, exige uma série de melhorias, como a correção dos cordões de nível, e a manutenção das pastagens. O dimensionamento correto e a reconstrução do sistema de microdrenagem no local são imprescindíveis, substituindo assim as estruturas problemáticas atualmente existentes. 0 recapeamento das vias também é uma boa opção, uma vez que atua na proteção dessa estrutura. Uma opção para a recuperação das grandes feições pode ser o seu aterramento, ou então apenas o controle de sua evolução, por meio do reflorestamento com nativas, por exemplo. Obras de macrodrenagem também podem ser adotadas no córrego, em conjunto com a recuperação das feições que o margeiam.

Os métodos de controle de erosão na Área 2 evoluíram ao longo do tempo, assim como seu uso e ocupação. Vários problemas foram identificados em todo o período analisado, envolvendo casos de má execução das estruturas, dimensionamento inadequado, escolhas erradas, entre outros. Analisando conjuntamente o uso e ocupação atual, as condições das medidas empregadas, e a evolução do processo erosivo no local, pode-se concluir que uma das principais necessidades dessa área inclui uma completa e bem dimensionada rede de micro e macrodrenagem. A atual configuração dessas estruturas, além de não proteger a área contra os processos erosivos, atua intensificando-os. $O$ aterro das feições e a revegetação das áreas de contribuição só serão efetivos no momento em que for eliminada a ação erosiva do escoamento 
pluvial. Dada à ocupação intensa dessa área, essas ações são importantes para a proteção dos elementos construídos e para manutenção do bem estar para a população.

A análise da área 3 identificou grandes benefícios com as medidas de recuperação empregadas no passado. Por outro lado, alguns prejuízos são visíveis atualmente, em decorrência da má execução do aterramento, e da ausência de medidas complementares mais efetivas. Da mesma forma que na Área 2, o aterro das feições deve ser acompanhado de drenos e/ou estruturas de macro drenagem. A proteção contra a erosão em áreas urbanas deve incluir ainda, necessariamente, uma completa rede de microdrenagem, caso contrário, a evolução gradual da erosão no local pode causar sérios prejuízos econômicos.

No que se refere à Área 4, verificou-se uma priorização da manutenção das encostas, com o emprego de medidas bastante eficientes nesses locais. Por outro lado as grandes feições foram deixadas de lado, de modo que sua configuração atual inviabiliza economicamente qualquer ação de recuperação. Nesse caso seria interessante empregar medidas que impedissem o escoamento superficial de atingir essas feições. Essa ação não seria suficiente para impedir o seu desenvolvimento, dada a atividade interna dessas voçorocas, mas retardaria sua evolução, contribuindo para a manutenção das encostas.

De um modo geral, verificou-se com esse estudo que a alteração da cobertura original do solo, sem a adoção de medidas de prevenção de erosão, pode levar ao surgimento de grandes feições erosivas, cuja recuperação torna-se extremamente custosa ou até mesmo inviável. Observou-se também que os problemas associados a não consideração das condições e características ambientais, a má execução, escolha inadequada e falta de manutenção das medidas de prevenção, controle e recuperação de erosão, também causam prejuízos ambientais e econômicos. Por outro lado, verificou-se que, em muitos casos, medidas simples, desde que bem executadas, podem prevenir os processos erosivos, ou controlá-los de forma eficiente, assim como a inspeção e manutenção das estruturas. Um projeto adequado e bem executado, apesar de exigir um grande investimento inicial, garante a eficiência do processo, e minimiza os gastos com correção, além de evitar prejuízos irreparáveis. O essencial é que sejam feitos estudos apurados das condições geológico-geotécnicas e ambientais, visando a melhor escolha da técnica a ser aplicada e sua correta execução.

A Tabela 18 a seguir lista as principais técnicas de prevenção, controle e recuperação identificadas, assim como uma breve análise de sua ineficiência e considerações sobre soluções técnicas que deveriam ser empregadas, com o objetivo principal de sintetizar as principais questões abordadas nesse estudo acerca dos processos de recuperação. 
Tabela 18: Síntese da análise da eficiência das técnicas avaliadas nesse trabalho.

\begin{tabular}{|c|c|c|c|c|}
\hline & Área 1 & Área 2 & Área 3 & Área 4 \\
\hline 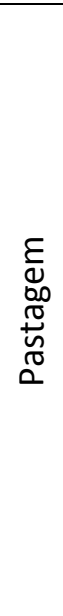 & $\begin{array}{c}\text { A pastagem em solos } \\
\text { arenosos, com a criação } \\
\text { intensiva de gado, foi } \\
\text { ineficiente na proteção do } \\
\text { solo contra a erosão, } \\
\text { acarretando o surgimento de } \\
\text { "falhas" que facilitam a ação } \\
\text { erosiva do escoamento. Para } \\
\text { que essa técnica seja utilizada } \\
\text { com sucesso, devem ser } \\
\text { adotadas práticas de manejo, } \\
\text { como o ressemeio periódico, } \\
\text { o controle do número de } \\
\text { animais por área, o rodízio de } \\
\text { pastagem, o uso de } \\
\text { fertilizantes, entre outros. }\end{array}$ & $\begin{array}{l}\text { Essa técnica foi utilizada antes da } \\
\text { implantação do bairro, no período de } \\
\text { surgimento de grandes feições. A } \\
\text { ineficiência dessa medida já foi } \\
\text { abordada anteriormente, estando } \\
\text { relacionada com o solo arenoso, e com } \\
\text { a ação de pisoteio do gado. O sucesso } \\
\text { dessa técnica, como foi dito, relaciona- } \\
\text { se com as práticas de manejo, como o } \\
\text { ressemeio periódico, o controle do } \\
\text { número de animais por área, o rodízio } \\
\text { de pastagem, o uso de fertilizantes, } \\
\text { entre outros. }\end{array}$ & $\begin{array}{l}\text { Essa técnica foi adotada no } \\
\text { passado, de forma associada com } \\
\text { a criação intensiva de gado, e com } \\
\text { solos muito arenosos, mostrando- } \\
\text { se ineficiente na prevenção e no } \\
\text { controle da erosão dado que leva } \\
\text { ao surgimento de "falhas", } \\
\text { expondo o solo, e facilitando a } \\
\text { ação erosiva do escoamento } \\
\text { superficial. Essa técnica também } \\
\text { não fornece proteção contra o } \\
\text { impacto direto das gotas na } \\
\text { superfície. }\end{array}$ & $\begin{array}{l}\text { A pastagem era utilizada antes da } \\
\text { substituição pelos eucaliptos. Essa } \\
\text { cobertura vegetal não impediu o } \\
\text { desenvolvimento de grandes } \\
\text { feições erosivas na área, } \\
\text { indicando a falta, tanto de } \\
\text { melhores práticas de conservação } \\
\text { e manejo (como o ressemeio } \\
\text { periódico, o controle do número } \\
\text { de animais por área, o rodízio de } \\
\text { pastagem, o uso de fertilizantes, } \\
\text { etc), quanto da adoção de outras } \\
\text { técnicas em conjunto. }\end{array}$ \\
\hline 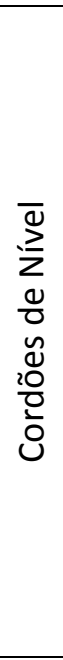 & $\begin{array}{l}\text { A construção dos cordões de } \\
\text { nível seguiu o relevo de } \\
\text { forma adequada. Porém a } \\
\text { largura do cordão deveria ser } \\
\text { entre } 1,5 \text { e } 2 \mathrm{~m} \text {, e não } 4 \mathrm{~m} \text {, } \\
\text { como foi observado. } 0 \\
\text { espaçamento recomendado } \\
\text { entre estes é de } 10 \text { a } 20 \\
\text { metros, mas em alguns } \\
\text { pontos observaram-se } \\
\text { valores de até } 30 \mathrm{~m} \text {. Essa } \\
\text { medida é recomendada para } \\
\text { inclinações suaves, sendo } \\
\text { esse o motivo de não se } \\
\text { encontrar cordões em áreas } \\
\text { mais inclinadas, próximas aos } \\
\text { canais. }\end{array}$ & $\begin{array}{l}\text { Essa medida foi adotada várias vezes ao } \\
\text { longo da evolução do uso e ocupação. } \\
\text { Mas pela análise das fotos aéreas, e por } \\
\text { trabalhos de campo, verificou-se que } \\
\text { estas não foram eficientes em prevenir } \\
\text { os processos erosivos, devido a erros de } \\
\text { dimensionamento, e à falta de } \\
\text { manutenção da estrutura. A falta de } \\
\text { obras de micro e macrodrenagem } \\
\text { contribuíram para a concentração dos } \\
\text { fluxos e sobrecarga das mesmas. }\end{array}$ & - & $\begin{array}{l}\text { Essa técnica foi aplicada em anos } \\
\text { anteriores à implantação do novo } \\
\text { uso do solo. Pode-se perceber } \\
\text { pela análise das fotos aéreas que } \\
\text { não houve muito critério em seu } \\
\text { dimensionamento, dada a } \\
\text { aleatoriedade de sua distribuição } \\
\text { espacial. Sua aplicação não } \\
\text { contribuiu para a prevenção da } \\
\text { evolução das feições de grande } \\
\text { porte existentes no local, } \\
\text { indicando à necessidade de se } \\
\text { cumprir as determinações de } \\
\text { dimensionamento e } \\
\text { espaçamento. }\end{array}$ \\
\hline
\end{tabular}


Continuação da Tabela 18.

\begin{tabular}{|c|c|c|c|c|}
\hline & Área 1 & Área 2 & Área 3 & Área 4 \\
\hline 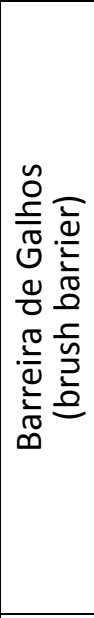 & - & - & - & $\begin{array}{l}\text { As barreiras foram intercaladas } \\
\text { com as fileiras de eucalipto, de } \\
\text { modo que a área de captação } \\
\text { relativa às barreiras é muito } \\
\text { menor do que o limite } \\
\text { determinado, assim como o } \\
\text { comprimento de encosta a } \\
\text { montante das barreiras. Por outro } \\
\text { lado, as dimensões das barreiras } \\
\text { estão menores que as } \\
\text { recomendadas, o que é } \\
\text { compensado pelo número } \\
\text { excessivo de barreias. Caso haja } \\
\text { material disponível é } \\
\text { recomendável que as barreiras } \\
\text { sejam aumentadas. }\end{array}$ \\
\hline 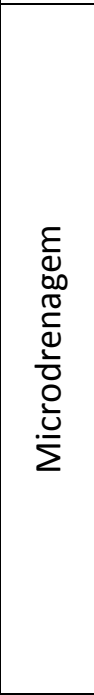 & $\begin{array}{l}\text { Os problemas relacionados a } \\
\text { essa técnica indicam a falta } \\
\text { de estudos para a } \\
\text { determinação da vazão, da } \\
\text { área de captação e de } \\
\text { questões estruturais } \\
\text { relacionadas às obras de } \\
\text { microdrenagem, que } \\
\text { resultaram no seu } \\
\text { subdimensionamento. Faltou } \\
\text { ainda determinar a } \\
\text { configuração ideal das } \\
\text { estruturas, e utiliza-las de } \\
\text { forma correta, de modo que } \\
\text { conduzissem o escoamento } \\
\text { prevenindo erosão, e não o } \\
\text { intensificando, como foi } \\
\text { observado. }\end{array}$ & $\begin{array}{c}\text { Não existem obras de microdrenagem } \\
\text { ao longo dessa área, como bocas de } \\
\text { lobo, galerias, sarjetas, entre outras. As } \\
\text { poucas estruturas presentes } \\
\text { encaminham o escoamento originado } \\
\text { nas vias, cuja disposição favorece a } \\
\text { concentração e a velocidade do mesmo, } \\
\text { para áreas desocupadas, contribuindo } \\
\text { para a erosão das mesmas. É essencial } \\
\text { que sejam feitos estudos estruturais e } \\
\text { hidrológicos visando dimensionar e } \\
\text { construir obras de disciplinamento da } \\
\text { água da chuva. }\end{array}$ & $\begin{array}{l}\text { Não existe nenhum tipo de } \\
\text { estrutura de microdrenagem } \\
\text { nessa área. Dado o uso urbano do } \\
\text { local, e as condições de evolução } \\
\text { da erosão verificadas, esse tipo de } \\
\text { estrutura é essencial. Devem ser } \\
\text { realizados os estudos estruturais e } \\
\text { hidrológicos necessários à escolha } \\
\text { adequada das estruturas a serem } \\
\text { usadas, e ainda o } \\
\text { dimensionamento e construção } \\
\text { das mesmas. }\end{array}$ & 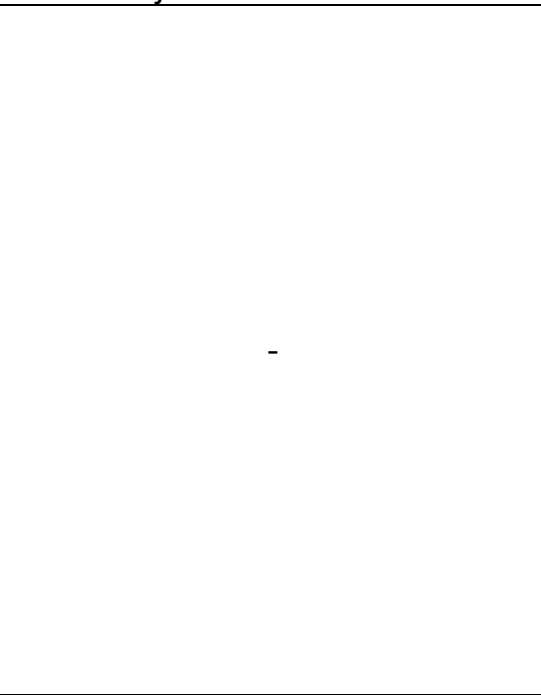 \\
\hline
\end{tabular}


Continuação da Tabela 18.

\begin{tabular}{|c|c|c|c|c|}
\hline & Área 1 & Área 2 & Área 3 & Área 4 \\
\hline 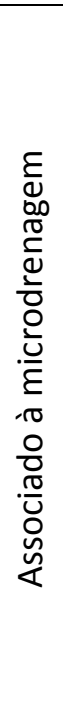 & $\begin{array}{c}\text { Nessa área, para tentar } \\
\text { diminuir a ação erosiva do } \\
\text { escoamento superficial } \\
\text { concentrado originado pelas } \\
\text { estruturas de microdrenagem } \\
\text { foram utilizados blocos de } \\
\text { rocha, muro de contenção e } \\
\text { curvas de nível. O mais } \\
\text { adequado seria melhorar o } \\
\text { sistema de microdrenagem, } \\
\text { eliminando os problemas } \\
\text { relacionados ao seu } \\
\text { dimensionamento e } \\
\text { disposição no terreno. Como } \\
\text { opção secundária, poderiam } \\
\text { ser empregados dissipadores } \\
\text { de energia, como escadas } \\
\text { hidráulicas ou enrocamento, } \\
\text { devidamente planejados. }\end{array}$ & - & - & - \\
\hline 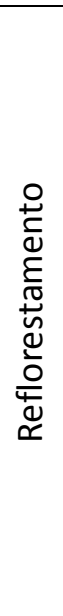 & - & $\begin{array}{l}\text { Nessa área foram utilizados pinus e } \\
\text { nativas. São reconhecidas as } \\
\text { vantagens dessa técnica, mas ela deve } \\
\text { ser aplicada levando-se em conta as } \\
\text { características físicas do local, como as } \\
\text { condições do solo e do clima. É } \\
\text { preferível que espécies nativas sejam } \\
\text { utilizadas, mas as exóticas também } \\
\text { podem ser aplicadas, desde que sua } \\
\text { adequabilidade seja verificada. Essa } \\
\text { técnica também exige manutenção, } \\
\text { principalmente no estágio inicial de } \\
\text { desenvolvimento. Caso sua aplicação } \\
\text { não se dê de forma correta, os } \\
\text { problemas de erosão podem ser } \\
\text { intensificados. }\end{array}$ & - & $\begin{array}{l}\text { O eucalipto utilizado na } \\
\text { revegetação dessa área consiste } \\
\text { numa espécie vegetal bastante } \\
\text { resistente, que se desenvolve } \\
\text { bem em solos pobres e secos, } \\
\text { mas sua adoção não deve } \\
\text { descartar estudos das condições } \\
\text { físicas do local. Dada a finalidade } \\
\text { comercial, a floresta é } \\
\text { constantemente derrubada e } \\
\text { replantada, de modo que a } \\
\text { manutenção deve ser intensa nos } \\
\text { primeiros estágios de } \\
\text { crescimento, e técnicas } \\
\text { complementares de proteção do } \\
\text { solo devem ser utilizadas. }\end{array}$ \\
\hline
\end{tabular}


Continuação da Tabela 18.

\begin{tabular}{|c|c|c|c|c|}
\hline & Área 1 & Área 2 & Área 3 & Área 4 \\
\hline 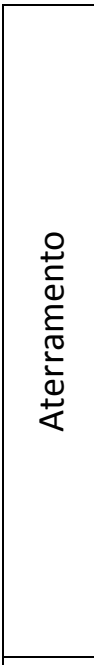 & - & $\begin{array}{l}\text { O aterro dessa área se deu utilizando o } \\
\text { próprio solo do local, sendo que a } \\
\text { compactação de restringiu aos lotes } \\
\text { ocupados. A aplicação dessa técnica faz } \\
\text { necessária uma análise do material } \\
\text { inconsolidado a ser empregado, para } \\
\text { avaliar se este é adequado, e para } \\
\text { prever detalhes da execução da técnica. } \\
\text { O aterro de áreas com fluxo } \\
\text { subsuperficial e superficial deve } \\
\text { envolver ainda drenos ou estruturas de } \\
\text { macrodrenagem, caso contrário o } \\
\text { aterro pode ser novamente erodido. }\end{array}$ & $\begin{array}{l}\text { O aterro dessa área utilizou o } \\
\text { próprio solo do local, sendo que a } \\
\text { compactação de restringiu aos } \\
\text { lotes ocupados e as vias. A } \\
\text { aplicação dessa técnica faz } \\
\text { necessária uma análise do do } \\
\text { material inconsolidado a ser } \\
\text { empregado, para avaliar se este é } \\
\text { adequado, para prever detalhes } \\
\text { da execução. O aterro de áreas } \\
\text { com fluxo subsuperficial e } \\
\text { superficial deve envolver ainda } \\
\text { drenos ou estruturas de } \\
\text { macrodrenagem, caso contrário o } \\
\text { aterro pode ser novamente } \\
\text { erodido, como foi observado } \\
\text { nesse local. }\end{array}$ & - \\
\hline 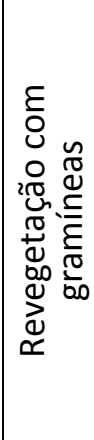 & - & $\begin{array}{l}\text { Nessa área as gramíneas foram } \\
\text { adotadas nos lotes desocupados, com o } \\
\text { objetivo de fornecer proteção ao solo. } \\
\text { Assim como o reflorestamento, a } \\
\text { revegetação com gramíneas exige } \\
\text { estudos das características físicas do } \\
\text { local, visando determinar qual a melhor } \\
\text { espécie e quais as melhores condições } \\
\text { de plantio. Essa medida pode ser bem } \\
\text { sucedida desde que associada à obras } \\
\text { de microdrenagem. }\end{array}$ & $\begin{array}{l}\text { Nessa área as gramíneas foram } \\
\text { adotadas junto com o aterro das } \\
\text { feições, visando proteger o solo. A } \\
\text { revegetação deve envolver } \\
\text { avaliação das condições físicas do } \\
\text { local e da adequabilidade da } \\
\text { espécie. A adequabilidade } \\
\text { também deve ser avaliada em } \\
\text { relação à presença ou ausência de } \\
\text { medidas complementares de } \\
\text { controle de erosão. }\end{array}$ & - \\
\hline
\end{tabular}


Continuação da Tabela 18.

\begin{tabular}{|c|c|c|c|c|}
\hline & Área 1 & Área 2 & Área 3 & Área 4 \\
\hline 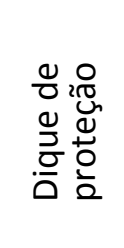 & - & - & $\begin{array}{l}\text { Essa técnica não é eficiente em } \\
\text { conter todo o escoamento } \\
\text { superficial da área, sendo um } \\
\text { paliativo para a ausência de obras } \\
\text { de microdrenagem, que por sua } \\
\text { vez seriam muito mais adequadas. }\end{array}$ & - \\
\hline 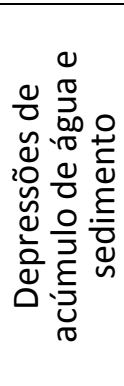 & - & - & - & $\begin{array}{c}\text { O uso dessa medida deve } \\
\text { envolver cálculos hidrológicos, } \\
\text { com a determinação da vazão, e } \\
\text { da área de captação de cada } \\
\text { depressão, de modo a se obter } \\
\text { as dimensões ideias da } \\
\text { estrutura. Deve ocorrer ainda a } \\
\text { manutenção da medida, pois o } \\
\text { assoreamento da mesma pode } \\
\text { prejudicar a sua função. }\end{array}$ \\
\hline
\end{tabular}




\section{CONCLUSÕES}

O estudo conjunto das características ambientais (geológicas, geotécnicas e hidrológicas) e do processo erosivo, assim como das medidas de controle e recuperação de erosão, de cada área estudada nesse trabalho, possibilitou a análise da eficiência e da adequação das medidas existentes. De maneira geral, as técnicas adotadas não atingiram seus objetivos, uma vez que foram implantadas sem considerar os condicionantes geológico-geotécnicos e as características hidrológicas. Em alguns casos verificou-se que as medidas empregadas eram inadequadas ou que não foram implantadas de forma correta, e ainda, que não houve a manutenção necessária.

Outro aspecto importante foi a não consideração dos usos subsequentes ou concomitantes com as tentativas de recuperação de cada área. A adoção das medidas deve fundamentalmente considerar quais os usos que darão continuidade em cada área.

Outro problema observado em praticamente todas as áreas relaciona-se com a falta ou subdimensionamento de obras de drenagem. Dada as condições naturais do meio físico, a ação erosiva do escoamento, e a ocupação urbana que ocorre na maioria das áreas, é imprescindível que os sistemas de drenagem sub e superficial sejam bem planejados. Muitos dos problemas observados nas Áreas 1, 2 e 3 poderiam ser resolvidos com uma rede de drenagem adequadamente planejada. Em alguns casos, medidas simples associadas, como a construção de dissipadores de energia resolveriam problemas que podem se agravar a cada dia. No caso de áreas aterradas, a presença de um sistema de drenagem subsuperficial é imprescindível, evitando que antigas feições sejam reativadas, como ocorreu na Área 2 (Feição F2) e 3 (Feição F1). Em alguns casos, buscando-se evitar a ação concentradora de fluxo das obras de drenagem, pode-se optar, sobretudo em áreas urbanas, pela utilização de áreas permeáveis, cujo objetivo principal é diminuir o volume do escoamento superficial.

A presença de grandes feições, que configuram voçorocas, em todas as áreas é outra questão a ser discutida. Os problemas relacionados às medidas de prevenção e controle contribuem para a rápida evolução do processo erosivo, de modo a estabelecer feições de grande porte. Essas feições exigem processos de recuperação onerosos, que devem envolver obras hidráulicas, retaludamento, aterramento entre outras. Mas em muitos casos o uso e a ocupação da área não justificam o investimento em uma recuperação desse porte, de modo que as feições permanecem inalteradas, e muitas vezes ativas, provocando prejuízos ambientais e 
econômicos. Desse modo, verifica-se a importância de se aplicar medidas de prevenção adequadas.

Em alguns casos observou-se ainda a adoção de medidas totalmente inadequadas, ou seja, foram empregadas estruturas cuja finalidade é diferente da que foi pretendida, como o que ocorreu na Área 1, em que um muro de contenção foi utilizado como dissipador de energia.

Além do subdimensionamento e da adoção de medidas inadequadas, outro problema bastante recorrente nas áreas relaciona-se a falta de manutenção das medidas empregadas. Não só a revegetação, mas qualquer estrutura ou conjunto de estruturas devem sofrer inspeção e manutenção periódicas, tanto para garantir seu funcionamento, quanto para corrigir possíveis falhas antes que as consequências sejam irreparáveis.

Em termos gerais, conforme foi demonstrado pela Tabela 18, algumas técnicas foram aplicadas com mais frequência nas áreas de estudo, em comparação com as demais. São estas: as pastagens, os cordões de nível e a microdrenagem. A importância da aplicação de obras de drenagem já foi discutida anteriormente, sendo que a grande frequência com que esta foi empregada evidencia ainda mais esse aspecto. Os problemas observados em relação à sua aplicação também atuam no sentido de confirmar a sua importância, e justificar a grande ocorrência. No que se referem às pastagens, estas normalmente ocorrem associadas à criação extensiva do gado, prática muito intensa no nosso País. De forma geral, quando bem manejando, o pasto mostra-se bastante eficiente na proteção do solo contra a erosão, dado que favorece a infiltração da água da chuva, e oferece resistência à formação do escoamento superficial acelerado. Características como essas justificam a adoção de gramíneas para a proteção do solo em áreas com usos diferentes da criação de gado; porém, apesar da ausência da ação do pisoteamento e do surgimento de trilhas dos animais, também é necessário que ocorra o manejo dessa técnica para garantir sua eficiência.

O cordão de nível é a terceira técnica mais observada nas áreas de estudo. Assim como a pastagem, essa medida é frequentemente observada em áreas agrícolas, seja associada aos pastos, seja associada a diferentes tipos de cultura. Sua utilização se dá com o objetivo de proteger o solo da erosão, impedindo ainda o transporte de grandes quantidades de sedimento. Nas áreas agrícolas sua manutenção ocorre no intervalo entre a colheita e um novo plantio, ou previamente ao replantio do pasto. Quando bem executados essa técnica é bastante eficiente, porém, sua aplicação normalmente se dá sem maiores preocupações técnicas, resultando assim em problemas, normalmente associados à capacidade de infiltração, retenção e direcionamento da água. Por outro lado, os bons resultados associados a essa técnica justificam sua adoção em 
áreas urbanas desocupadas, como o observado na Área 2 desse trabalho. Nesse caso, os mesmos cuidados necessários nas áreas rurais devem ser adotados para garantir sua funcionalidade.

A técnica de aterramento das feições foi observada em duas áreas desse trabalho (Área 2 e 3) como solução para a recuperação de grandes feições (voçorocas); sendo ainda apresentada como possível solução para parte do problema erosivo da Área 1. Os benefícios obtidos com essa técnica justificam a sua recomendação para a recuperação de feições de maior porte, porém, como foi discutido anteriormente, é imprescindível a adoção de sistemas de drenagem subsuperficial, para garantir a sua eficiência.

Com esse estudo pode-se verificar ainda que a prevenção e controle dos processos erosivos menos intensos, como a erosão difusa, ou a linear sob a forma de sulcos, é bastante eficiente com a adoção de medidas como cobertura vegetal, cordões de nível ou barreiras de galhos. De forma geral essas medidas são simples e não envolvem grandes custos de aplicação, evidenciando que a proteção contra a erosão é a alternativa mais viável.

É possível afirmar também que dificilmente uma técnica será eficiente se aplicada sozinha. Combinações de técnicas são sempre mais indicadas, pois cada uma é indicada a atuar com foco em algum condicionante ou deflagrador específico do processo erosivo. A escolha das técnicas a serem aplicadas em conjunto, além de levar em conta todos os aspectos relacionados ao meio ambiente, deve ainda buscar medidas que sejam complementares e adequadas ao problema a ser resolvido.

Finalmente, em relação aos custos, verifica-se que a recuperação, sobretudo em casos que envolvam grandes feições erosivas, é sempre mais onerosa, dada a complexidade das técnicas necessárias, e do número de medidas concomitantes que devem ser aplicadas. A proteção do solo é a alternativa mais viável, tanto economicamente, quanto ambientalmente, uma vez que evita os processos de degradação. Nesse sentido, a execução adequada dos projetos também envolve economia nos custos, dado que evita o agravamento do processo, e a necessidade de se refazer diferentes estruturas. 


\section{REFERÊNCIAS}

ALASKA DEPARTMENT OF TRANSPORTATION AND PUBLIC FACILITIES. Erosion and Sediment Control In: Alaska Highway Drainage Manual. 2001. [Acessado em 26 de Setembro]. Disponível em: < http://www.dot.state.ak.us/stwddes/desbridge/pop_hwydrnman.shtml>.

ASSOCIAÇÃO BRASILEIRA DE NORMAS TÉCNICAS. NBR 10703: Degradação do solo: terminologia. Rio de Janeiro, 1989, $45 \mathrm{p}$.

AYRES, Q. C. Soil Erosion and its Control. McGraw-Hill, New York, London, 1936.

BARROSO, L. V.; SILVA, J. C. L.; BARBOSA, A. L.; FILHO, L. P. A. P. Controle da Erosão por Reflorestamento no Talude da Estrada de Itaipu, Região Oceânica de Niterói (Região Metropolitana do Rio de Janeiro). In: Simpósio Nacional de Controle de Erosão, 7. 2001, Goiânia. Anais...Goiânia: ABGE, 2001. 10p.

BARROW, E. G. C. The value of traditional knowledge in present-day soil-conservation practice: the example of West Pokot and Turkana. In: THOMAS, D. B., BIAMAH, E. K., KILEWE, A. M. LUNDGREN, L., MOCHOGE, B. O. Soil Conservation in Kenya. Nairobi, Department of Agricultural Engineering, University of Nairobi and Swedish International Development Authority.1989. p. $471-485$.

BARROW, C. J. Land degradation: developments of terrestrial environments. Cambridge University Press. 1991. 285 p.

BEASLEY, R. P. Erosion and Sediment Pollution Control. The lowa State University Press, Ames, lowa. 1972. $320 \mathrm{p}$.

BERTONI, J. O espaçamento dos terraços em culturas anuais, determinado em função das perdas por erosão. Bragantia, Campinas, SP. V. 18. 1959. p. $113-140$. 
BERTONI, J., LOMBARDI NETO, F. Conservação do solo. 3. ed. São Paulo: Editora Ícone, 1993. $355 p$.

BIDONE, F., TUCCI, C. E. M. Microdrenagem. In: TUCCI, C. E. M., PORTO, R. L. L., BARROS, M. T. Drenagem Urbana. Porto Alegre: ABRH/Editora da Universidade UFRGS, 1995. p. 77 - 106.

BITAR, O. Y., BRAGA, T.O. O Meio Físico na Recuperação de Áreas Degradadas. In: Bitar, O. Y. Curso de Geologia Aplicada ao Meio Ambiente. São Paulo: Associação Brasileira de Geologia de Engenharia, 1995. p. 165 - 177.

BLUM, W. E. H. Basics Concepts: Degradation, Resilience and Rehabilitation. In: LAL, R.; BLUM, W. H.; Valentine, C.; STEWART, B. A. Methods for Assessment of Soil Degradation. CRC Press. Coca Raton. 1997. p. 1- 16.

BOX, J., BRUCE, R.R. The Effect of the Surface Cover on Infiltration and Soil Erosion. In: AGASSI, M. Soil Erosion Conservation, and Rehabilitation. Marcel Dekker, Inc. New york. 1996. p. 107 123.

CADENAS DE LLANO, F. L.; Conservacion de suelos. In: Restauración hidrológico forestal de cuencas y control de la erosión. Ingeniería Medioambiental. 2ª edición. 1998. P. 443 - 550.

CAVAGUTI, N. Uso do lixo no controle de erosão. In: Simpósio Nacional de Controle de Erosão, 5. 1995. Bauru. Anais...Bauru: ABGE, 1995. p. $97-100$.

CARVALHO, P. A. S. (Coordenador). Manual de geotecnia: taludes de rodovias: orientação para diagnóstico e soluções de seus problemas. Instituto de Pesquisas Tecnológicas, 1991.

CHIRINO, E.; BONET, A.; BELLOT, J.; SÁNCHEZ, J. R. Effects of 30-year-pld Aleppo pine plantations on runoff, soil erosion and plant diversity in a semi-arid landscape in south eastern Spain. In: Catena. V. 65. 2006. p. $19-29$.

CUNHA, M. A.; SANTOS, A. R. Técnicas simples de controle de erosão em estradas de terra. In: Simpósio Nacional de Controle de Erosão, 3. 1985. Maringá. Anais... São Paulo: ABGE. 
DEPARTAMENTO DE ÁGUAS E ENERGIA ELÉTRICA. Controle de erosão: bases conceituais e técnicas, diretrizes para planejamento urbano e regional; orientação para o controle de boçorocas urbanas. 1a ed. São Paulo: DAEE/IPT. 1989.

DEPARTAMENTO DE ÁGUAS E ENERGIA ELÉTRICA. Controle de erosão: bases conceituais e técnicas, diretrizes para planejamento urbano e regional; orientação para o controle de boçorocas urbanas. 2a ed. São Paulo: DAEE/IPT. 1990.

DEPARTAMENTO NACIONAL DE INFRAESTRUTURA DE TRANSPORTES. DNIT 030/2004 - ES. Drenagem - Dispositivos de drenagem pluvial urbana - Especificação de Serviço. Rio de Janeiro RJ. 2004. 7 p. [Acesso em 13 de Fevereiro de 2012]. Disponível em: <http://ipr.dnit.gov.br/normas/DNIT030 2004 ES.pdf>.

ELLISON, W.D. Soil erosion studies part I. Agricultural Engineering, v.28, n.4, 1974, p.145-146.

EL-SWAIFY, S.A.; DANGLER, E.W.; ARMSTRONG, C.L. Soil erosion by water in the tropics. Hitahr College of Tropical Agriculture and Human Resources, University of Hawai, 1982, 173p.

EMBRAPA. Centro Nacional de Pesquisa de Solos (Rio Branco, AC). Construção de terraços para controle da erosão pluvial no Estado do Acre (1a Edição). Brasília: Embrapa Acre, 2004. 47p.

FAO. Watershed management field manual (1986). Manual gully control. Rome, Itália. 20p.

FERNANDES, C. Microdrenagem - Um estudo inicial. UFPB, Campina Grande, 2002, 196p. [Acesso em 05 de Fevereiro de 2012]. Disponível em: <http://www.dec.ufcg.edu.br/saneamento/Drenagem.html $>$.

FENDRICH, R. Erosão Urbana. In: FENDRICH, R.; OBLADEN. N. L.; AISSE, M. M.; GARCIAS. C. M. Drenagem e controle da erosão urbana. Curitiba: Editora Champagnat, 1997a. p.17-52. 
Hidrologia aplicada. In: FENDRICH, R.; OBLADEN. N. L.; AISSE, M. M.; GARCIAS. C. M. Drenagem e controle da erosão urbana. Curitiba: Editora Champagnat, 1997b. p.125-194.

FERNANDES; D. O. Erodibilidade de Materiais Inconsolidados da Bacia do Ribeirão Samambaia (Região de São Pedro - SP). Dissertação (Mestrado) - Escola de Engenharia de São Carlos, Universidade de São Paulo, São Carlos, 2003.

FERREIRA, M. D. Análise da evolução dos processos erosivos acelerados em áreas urbanas e das técnicas de controle e recuperação - Córrego do Tucum (São Pedro/SP). Dissertação (Mestrado) - Escola de Engenharia de São Carlos, Universidade de São Paulo, São Carlos, 2004.

FILIZOLA, H.F.; ALMEIDA FILHO, G. S.; CANIL, K.; SOUZA, M. D.; GOMES, M. A. F. Controle dos processos erosivos lineares (ravinas e voçorocas) em áreas de solos arenosos. Jaguariúna: Embrapa Meio Ambiente. Circular Técnica, 22. 2011. 7 p. [Acesso em 20 de Janeiro de 2012]. Disponível em: <http://www.infoteca.cnptia.embrapa.br/handle/doc/915009>.

FUNDAÇÃO ESTADUAL DE MEIO AMBIENTE. Orientações básicas para drenagem urbana. Belo Horizonte, 2006. 32p. [Acesso em 13 de Fevereiro de 2012]. Disponível em: $<$ http://www.minasmenosresiduos.com.br/doc/infoteca/Cadernos\%20Tecnicos/OrientacoesBasicas-para-Drenagem-Urbana.pdf>.

GALERANI, C.; CHAVES, E.; MACEDO FILHO, J.; SANTOS, L.; SILVA, P. Controle da Erosão Urbana. In: TUCCI, C. E. M.; PORTO, R. LA L., BARROS, M. T. Drenagem Urbana. Porto Alegre: ABRH/Editora da Universidade UFRGS, 1995. p. $349-386$.

GRAY, D. H., LEISER, A. T. Structural-Mechanical Components of Biotechnical Slope Protection. In: Biotechnical slope protection and erosion control. Van Nostrand Reinhold company, New York. 1982. p. $83-121$.

GRAY, D. H., SOTIR, R. B. Biotechnical and soil bioengineering slope stabilization: a pratical guide for erosion control. John Wiley \& Sons, Inc., 1995. 378p. 
GRISSINGER, E. H. Reclamation of gullies and channel erosion. In: AGASSI, M. Soil erosion, conservation and rehabilitation. Marcel Dekker, Inc. New york. 1996. p. $301-313$.

GUERRA, A. J. T. O Início do Processo Erosivo. In: GUERRA, A. J. T.; SILVA, A. S.; BOTELHO, R. G. M. Erosão e Conservação dos Solos: Conceitos, Temas e Aplicações. 6a . Edição, Rio de Janeiro: Bertrand Brasil, 2010. 340p.

GUERRA, A. J. T. Processos erosivos nas encostas. In: GUERRA, A. J. T., CUNHA, S. B. Geomorfologia: Uma Atualização das Bases e Conceitos. 3a. Edição. Rio de Janeiro: Bertrand Brasil, 1998.p. $149-210$.

GUIDICINI, G.; NIEBLE, C. M. Estabilidade de taludes naturais e de escavação. São Paulo. Editora da Universidade de São Paulo, 1976. 170 p.

INFANTI Jr., N., FORNASARI FILHO, N. Processos de dinâmica superficial. In: Oliveira, A. M. S., Brito, S. N. A. Geologia de Engenharia. São Paulo: Associação Brasileira de Geologia de Engenharia, 1998. p. 131-143.

IWASA, O. Y.; FENDRICH, R. Controle de Erosão Urbana. In: OLIVEIRA, A. M. S. e BRITO, S. N. A. (editores). Geologia de Engenharia. São Paulo: Associação Brasileira de Geologia de Engenharia, cap. 16, pag. $271-281,1998$.

KELLER, G., SHERAR, J. Erosion Control. In: Low-volume roads engineering: best management practices, field guide. US Agency for International Development, 2003, p. 129 - 140.

KERTZMAN, F. F., PASTORE, E. L., RIDENTE JR. J. L. Dique drenante como solução para combate à boçoroca urbana. In: Simpósio Nacional de Controle de Erosão, 5. 1995. Bauru. Anais...Bauru: ABGE, 1995. p. $341-343$.

LAFLEN. J. M.; ROOSE, E. J. Methodologies for Assessment of Soil Degradation Due to Water Erosion. In: LAL, R.; BLUM, W. H.; Valentine, C.; STEWART, B. A. Methods for Assessment of Soil Degradation. CRC Press. Coca Raton. 1997. p. 31- 55. 
LAL, R. Soil erosion in the tropics - principles and management. McGraw-Hill, New York, 1990, $580 p$.

MAGALHÃES, R. A. Erosão: Definição, tipos e formas de controle. In: Simpósio Nacional de Controle de Erosão, 7. 2001, Goiânia. Anais...Goiânia: ABGE, 2001.

MARTINS, J. R. S. Obras de Macrodrenagem. In: TUCCI, C. E. M.; PORTO, R. LA L., BARROS, M. T. Drenagem Urbana. Porto Alegre: ABRH/Editora da Universidade UFRGS, 1995. p. 167 - 275.

MATTOS, N. J. R. Técnicas na execução de obras para controle da erosão com estruturas de aço corrugado. In: Simpósio Nacional de Controle de Erosão, 5. 1995. Bauru. Anais...Bauru: ABGE, 1995. p. $123-125$.

MORGAN, R.P.C. Soil erosion and its control. $2^{\text {nd }}$ ed. Longman. New York. 1995, $198 p$.

MORGAN, R.P.C., QUINTON, J. N. AND RICKSON, R. J. Modeling methodology for soil erosion assessment and soil conservation design: eurosem approach. Outlook on Agriculture, v.3, 1994. p.5-9.

MORGAN, R. P. C.; RICKSON, R. J. Water erosion control. In: Slope Stabilization and Erosion Control: A Bioengineering Approach. $1^{\text {st }}$ ed. 1995. p. $133-191$.

NISHIYAMA, L. Procedimentos de mapeamento geotécnico como base para análise e avaliações ambientais do meio físico em escala 1:100.000 aplicação no município de Uberlândia - MG. Tese (Doutorado). São Carlos 1998.

NISHIYAMA, L. Erosão do solo: uma visão integrada dos fatores e processos que condicionam o seu desenvolvimento. Seminários Gerais em Geotecnia - SGS - 833, EESC/USP. São Carlos - SP, 1995.

NYSSEN, J.; POESEN, J.; GEBREMICHAEL, D.; VANCAMPENHOUT, K.; D’AES M.; YIHDEGO, G.; GOVERS, G.; LEIRS, H.; MOEYERSONS, J.; NAUDTS, J.; HAREGEWEYN, N.; HAILE, M.; DECKERS, J. 
Interdisciplinary on-site evaluation of stone bunds to control soil erosion on cropland in Northern Ethiopia. In: Science Direct. Soil \& Tillage Research 94. 2007. p. 151 - 163.

OBLADEN, N.L. Prevenção à erosão urbana. In: FENDRICH, R.; OBLADEN. N. L.; AISSE, M. M.; GARCIAS. C. M. Drenagem e controle da erosão urbana. Curitiba: Editora Champagnat, 1997. p.53- 121 .

OLIVEIRA, J. M. A. D. S. Contribuições geotécnicas para o estudo do problema da erosão. Dissertação (Mestrado) - Universidade Técnica de Lisboa, Instituto Superior Técnico, Lisboa, 2006.

PEREIRA, A. R. Como Selecionar Plantas para Áreas Degradadas e Controle de Erosão. 2008. [Acesso em 24 de Outubro de 2011]. Disponível em: $<$ http://www.deflor.com.br/portugues/pdf/LivroSEAD.pdf $>$.

POMPÊO, C. A. Sistemas urbanos de microdrenagem. Notas de aula. UFSC. Florianópolis - SC. 2001. 60p. . [Acesso em 15 de Fevereiro de 2012]. Disponível em: $<$ http://www.ens.ufsc.br/ roberto/disciplinas/drenagem/Microdrenagem.pdf>.

RIDENTE JR, J. L. Caracterização de erosões e diretrizes para o controle corretivo e preventivo em bacias de contribuição do alto do Araguaia, GO/MT. In: ConGresso Brasileiro de Geologia de Engenharia, 9. 1999. Anais... São Pedro. ABGE. São Pedro, São Paulo.

RIGHETTO, A. M. Hidrologia e recursos Hídricos. São Carlos: Editora da Escola de Engenharia de São Carlos - Universidade de São Paulo. 1998. 819 p.

RODRIGUES, J.E. Estudo de fenômenos erosivos acelerados: boçorocas. Tese (Doutorado) Escola de Engenharia de São Carlos, Universidade de São Paulo, São Carlos, 1982.

RODRIGUES, R.; LOPES, J. A. U. Rodovias. In: OLIVEIRA, A. M. S. e BRITO, S. N. A. (editores). Geologia de Engenharia. São Paulo: Associação Brasileira de Geologia de Engenharia, cap. 25, pag. $419-430,1998$. 
ROMERO-DÍAZ, A.; BERMONTE-SERRATO, F.; RUIZ-SINOGA, J. D. The Geomorphic Impact of Afforestations on Soil Erosion in Southeast Spain. In: Land Degradation \& Development. V. 21. 2010. p. $1888-195$.

ROSA, F. S.; NATIVIDADE, H.; CHISCA JUNIOR, H.; TARDELLI FILHO, J.; LAVRADOR FILHO, J.; CHIOSSI, N. J. A erosão na Região Metropolitana da Grande São Paulo. In: Simpósio sobre controle de erosão, 2.,1981, São Paulo. Anais...São Paulo: ABGE, 1981. p. 75 - 100.

ROTTA, C. M. S., ZUQUETTE, L. V. Estudo da recuperação de áreas degradadas por erosão no Município de São Pedro - São Paulo, Brasil. In: Congresso Luso-brasileiro de Geotecnia, 6. 2012. Lisboa. Anais...Lisboa - Portugal. 59.

SALOMÃO, F. X. T., IWASA, O. Y. Erosão e ocupação rural e urbana. In: Bitar, O. Y. Curso de Geologia aplicada ao meio ambiente. São Paulo: Associação Brasileira de Geologia de Engenharia, 1995. p. 31-57.

SALOMÃO, F. X. T. Controle e Prevenção dos Processos Erosivos. In: GUERRA, A. J. T.; SILVA, A. S.; BOTELHO, R. G. M. Erosão e Conservação dos Solos: Conceitos, Temas e Aplicações. 6ạ. Edição, Rio de Janeiro: Bertrand Brasil, 2010. 340p.

SÁNCHEZ, L. H. Avaliação de Impacto Ambiental: conceitos e métodos. São Paulo. Oficina de Textos, 2006.

SANG-ARUN, J., MIHARA, M., HORAGUCHI, Y., YAMAJI, E. Soil erosion and participatory remediation strategy for bench terraces in northern Thailand. In: Catena. V. 65. 2006. p. 258 264.

SELBY, M. J. Erosion of Hillslope by Raindrops and Flowing Water. In: Hillslope Materials and Processes. New York, Oxford University Press, 1993, p.219-248.

SOUZA, M. L. de - Proposta de um Sistema de Classificação de Feições Erosivas voltados a Estudos de Procedimentos de Análises de Decisões quanto a Medidas Corretivas, Mitigadoras 
e Preventivas: Aplicação no Município de Umuarama (PR). Tese (Doutorado). UNESP. Rio Claro, 2001.

SPONGA, M.; COELHO, I. Recuperação de voçoroca no Jardim Botânico de Goiânia com uso de técnicas de engenharia naturalista. In: Simpósio Nacional de Controle de Erosão, 7. 2001. Goiânia. Anais...Goiânia: ABGE, 2001. 14 p.

TOY, T. J., FOSTER, G. R., RENARD, K. G. Soil erosion: processes, prediction, measurement, and control. John Wiley \& Sons, Inc. 2002. P. $25-53$ e $199-206$.

UNGER, P. W. Common Soil and Water Conservation Practices. In: AGASSI, M. Soil erosion, conservation and rehabilitation. Marcel Dekker, Inc. New york. 1996. p. $239-266$.

VIRGINIA DEPARTMENT OF CONSERVATION \& RECREATION. Virginia Erosion and Sediment Control Handbook. Chapter 3. 3rd. ed. 1992. [Acesso em: 26 de Setembro de 2011]. Disponível em: $\langle$ http://www.dcr.virginia.gov/stormwater management/e and s-ftp.shtml>.

WEILL, M. A. M; PIRES NETO, A. G. Erosão e Assoreamento. In: SANTO, R. F. (organizadora). Vulnerabilidade Ambiental: Desastres Naturais ou Induzidos? Brasília: MMA, 2007.

XUJIONGXIN. Benggang erosion: the influencing factors. In: Catena. V.27. 1996. p. $249-263$.

YAMANOUth, G. R. B. Avaliação dos Processos Erosivos e das Técnicas de Controle e Reabilitação - Bacia do Córrego do Espraiado (São Pedro - SP). Dissertação (Mestrado) - Escola de Engenharia de São Carlos, Universidade de São Paulo, São Carlos, 2003.

ZACHAR, D. Soil erosion. New York: Elsevier Scientific. Developments in Soil Science. 1982. 548p.

ZHANG, B.; YANG, Y.; ZEPP, H. Effect of vegetation restoration on soil and water erosion and nutrient losses of severely eroded clayey Plinthudult in southeastern China. In: Catena. V57. 2004. p. $77-95$. 
ZUQUetTE, L. V. Análise Crítica da Cartografia Geotécnica e Proposta metodológica para as Condições Brasileiras. Tese (Doutorado). Escola de Engenharia de São Carlos, Universidade de São Paulo, São Carlos, 1987. 


\section{ANEXO 1}

Modelo da Ficha de Campo desenvolvida para auxílio no desenvolvimento desse trabalho. 



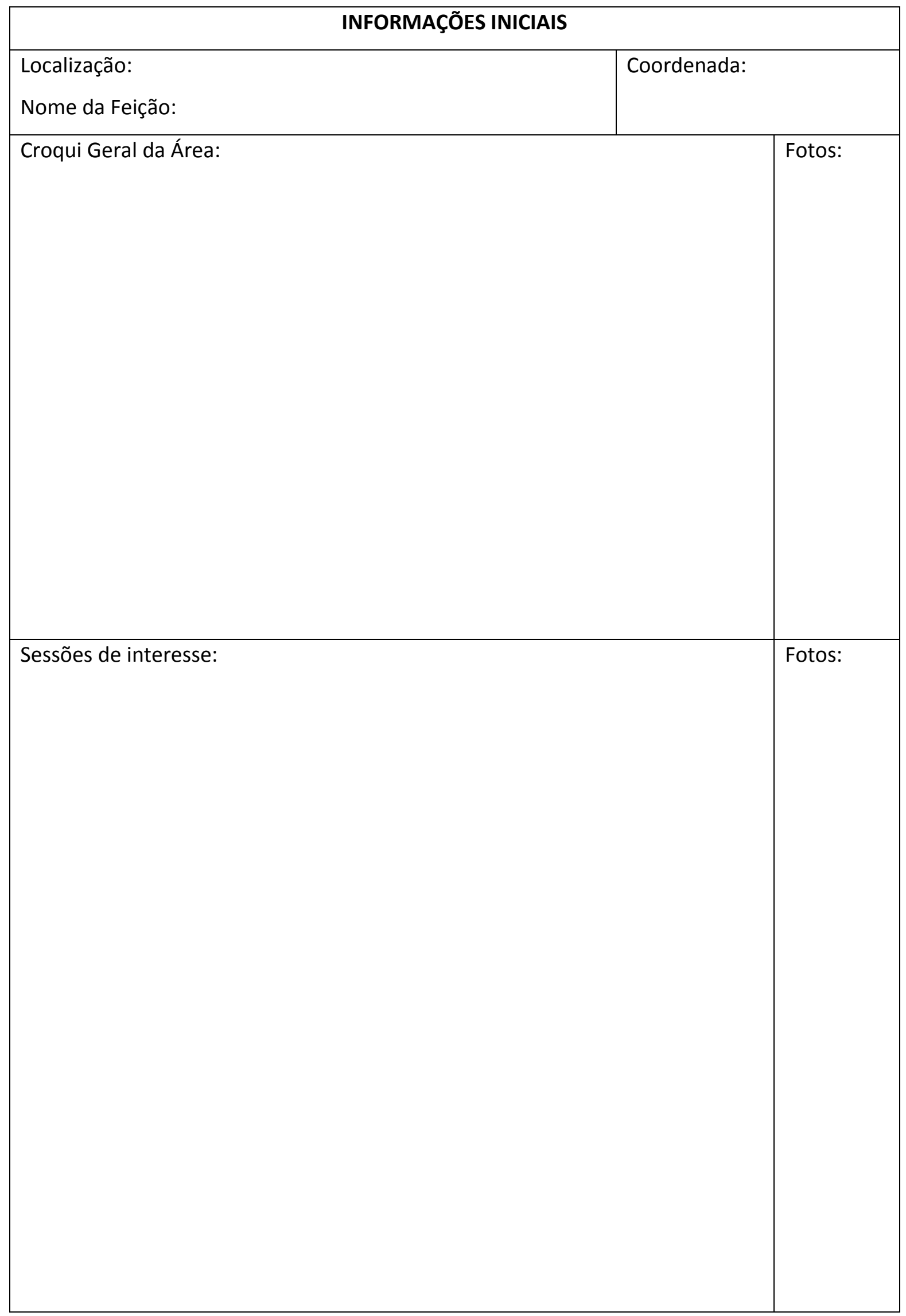




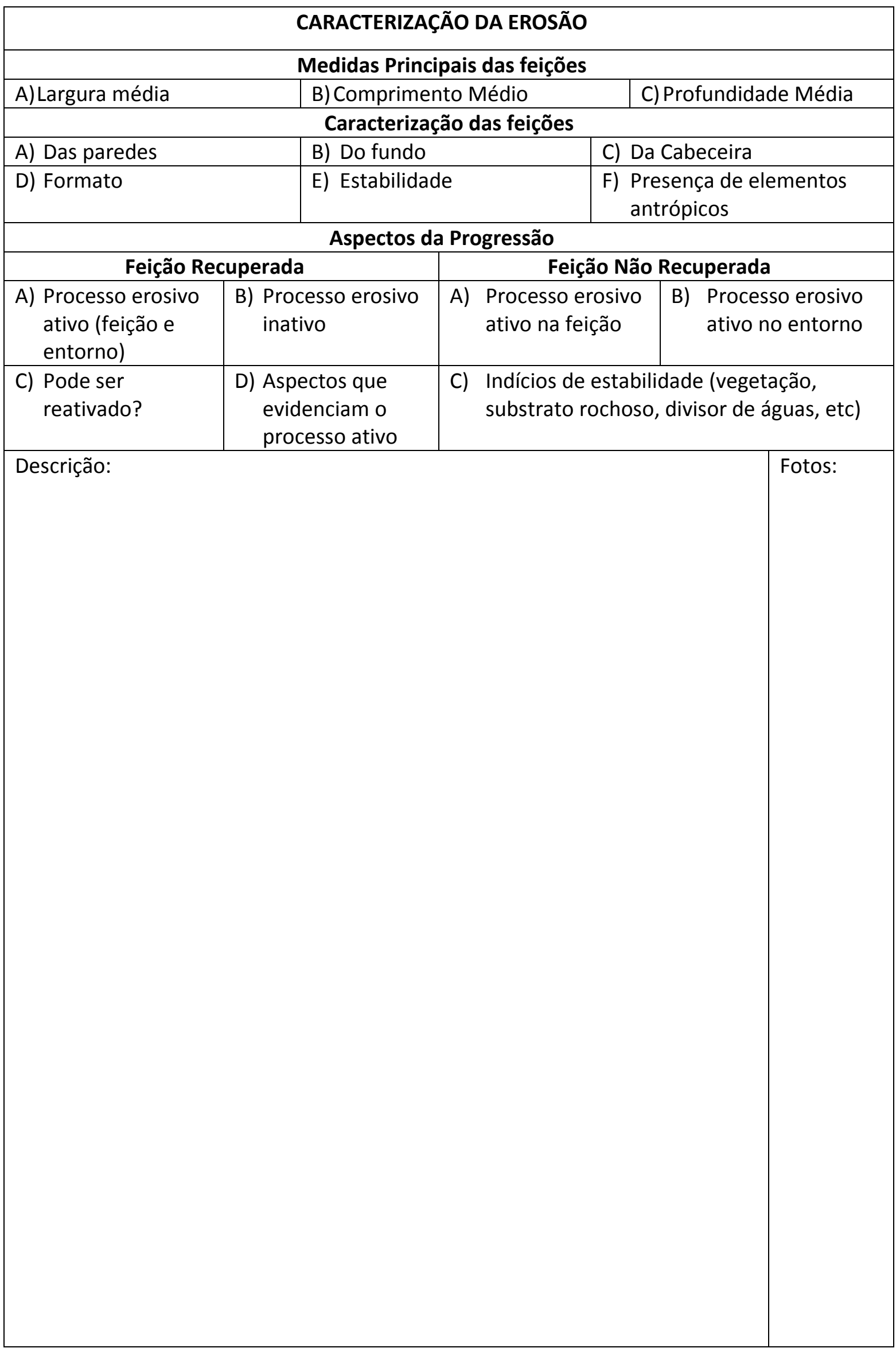




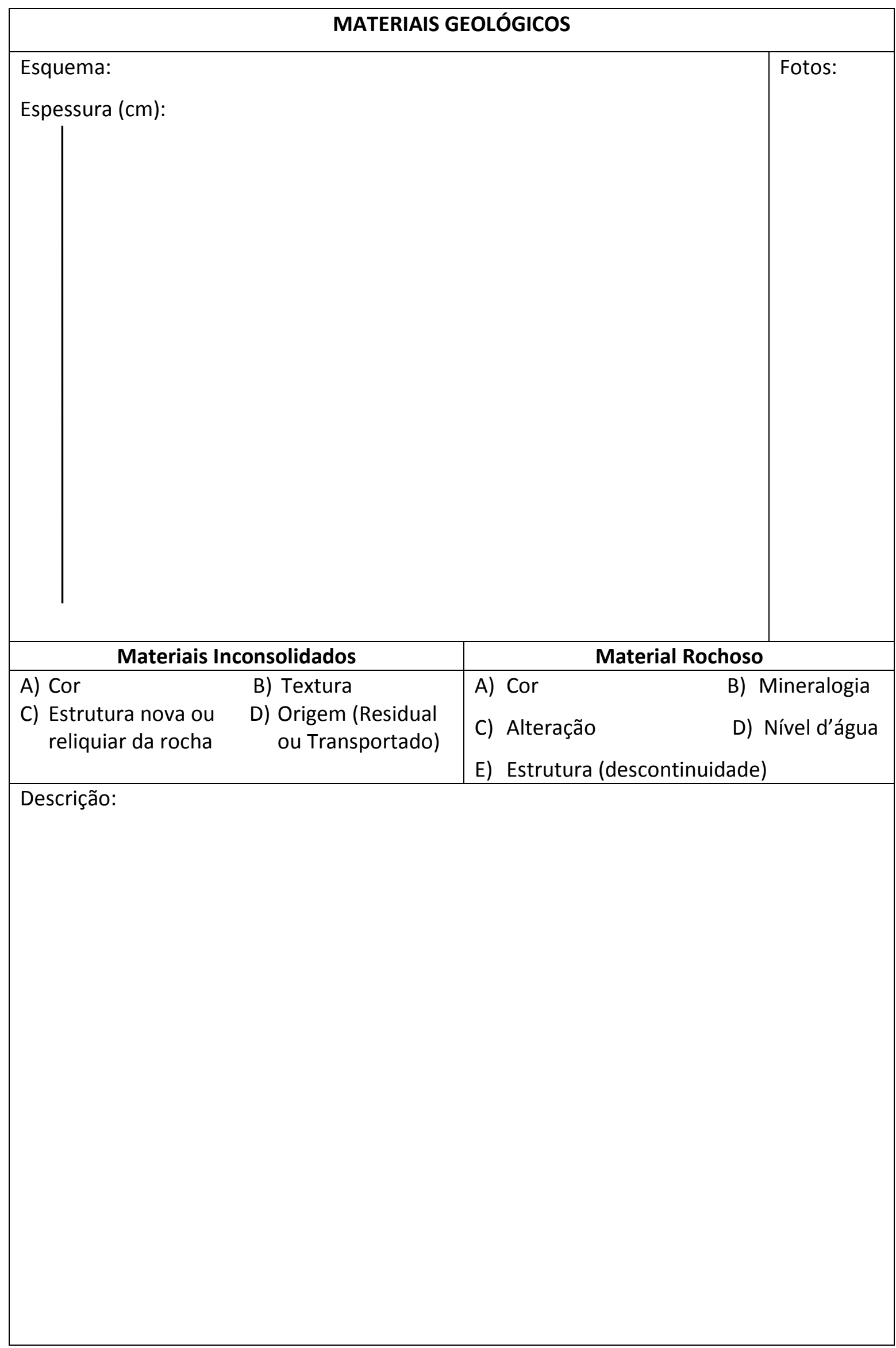




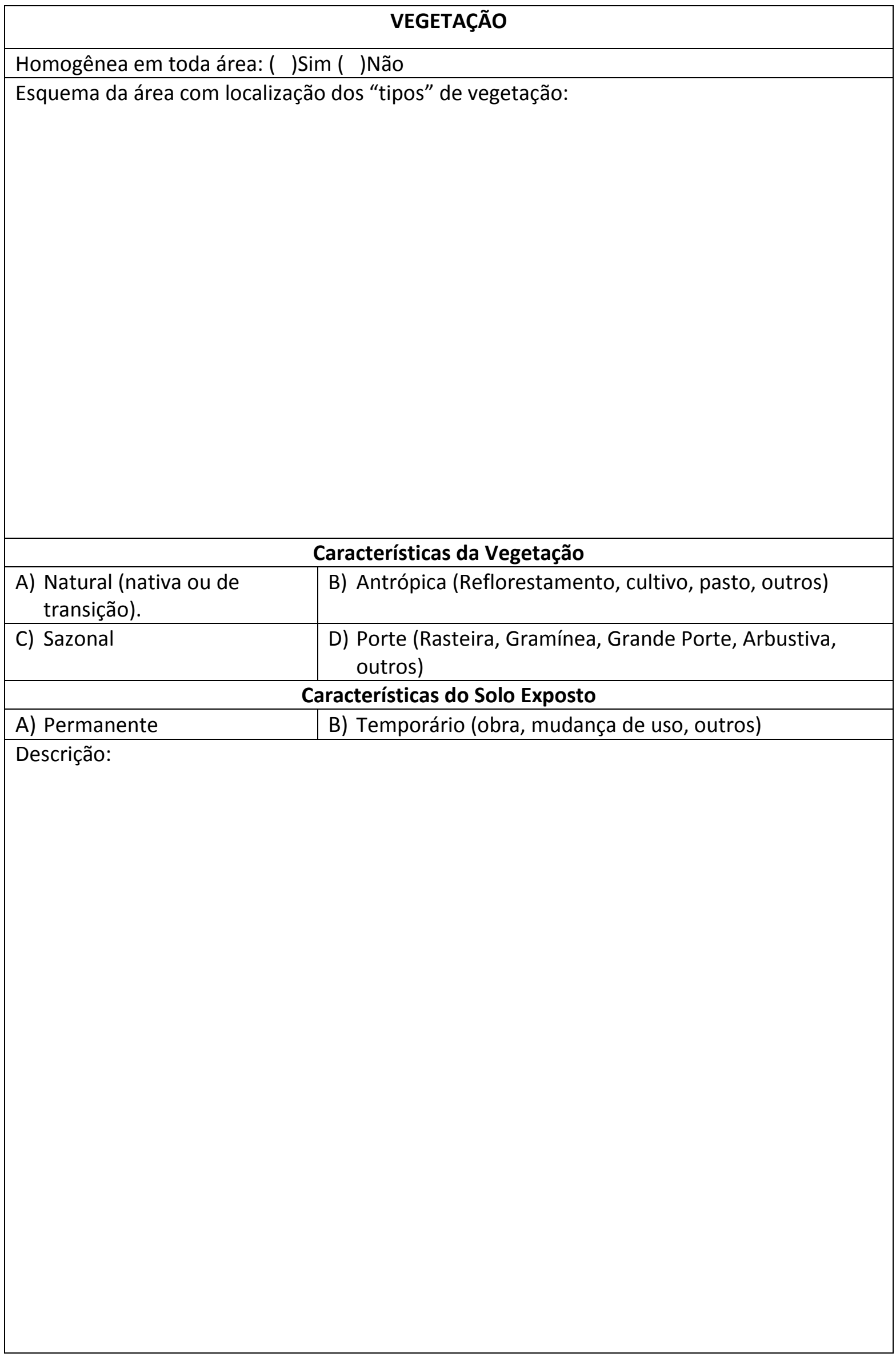




\begin{tabular}{|c|c|c|c|}
\hline \multicolumn{4}{|c|}{ USO DA ÁREA } \\
\hline \multicolumn{3}{|c|}{ Croqui esquemático da distribuição dos usos na área: } & Fotos: \\
\hline \multicolumn{4}{|c|}{ Descrição do Uso e Ocupação } \\
\hline $\begin{array}{l}\text { A) Uso e ocupação } \\
\text { da feição }\end{array}$ & $\begin{array}{l}\text { B) Uso e ocupação do } \\
\text { entorno }\end{array}$ & $\begin{array}{l}\text { C) Uso orientado/pré- } \\
\text { estabelecido }\end{array}$ & $\begin{array}{r}\text { D) Uso não } \\
\text { previsto }\end{array}$ \\
\hline $\begin{array}{l}\text { E) Estruturas de } \\
\text { usos prévios }\end{array}$ & $\begin{array}{l}\text { F) Situação de Risco } \\
\text { Iminente }\end{array}$ & & \\
\hline \multicolumn{4}{|l|}{ Descrição: } \\
\hline
\end{tabular}




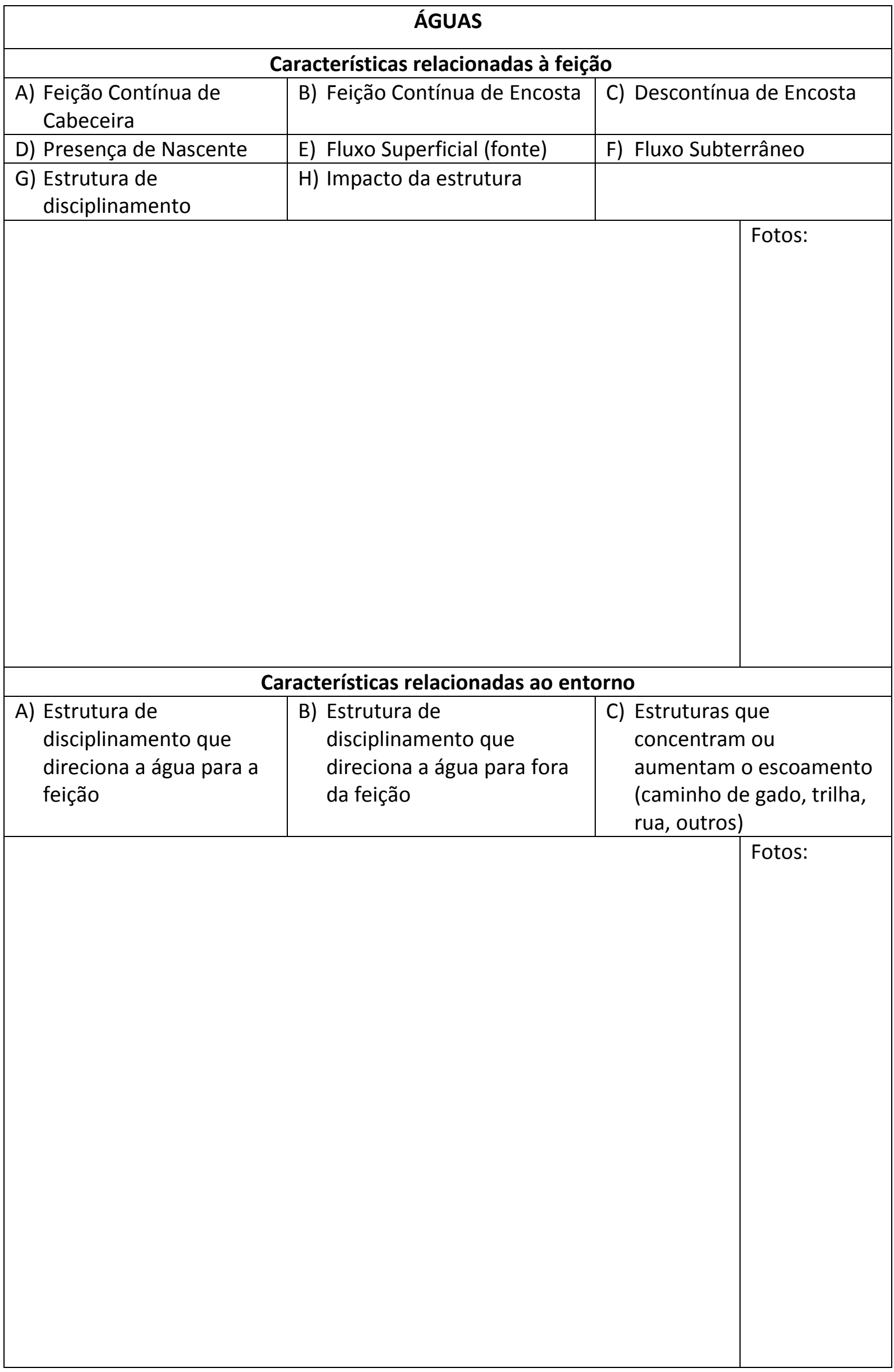


MEDIDAS DE RECUPERAÇÃO ADOTADAS

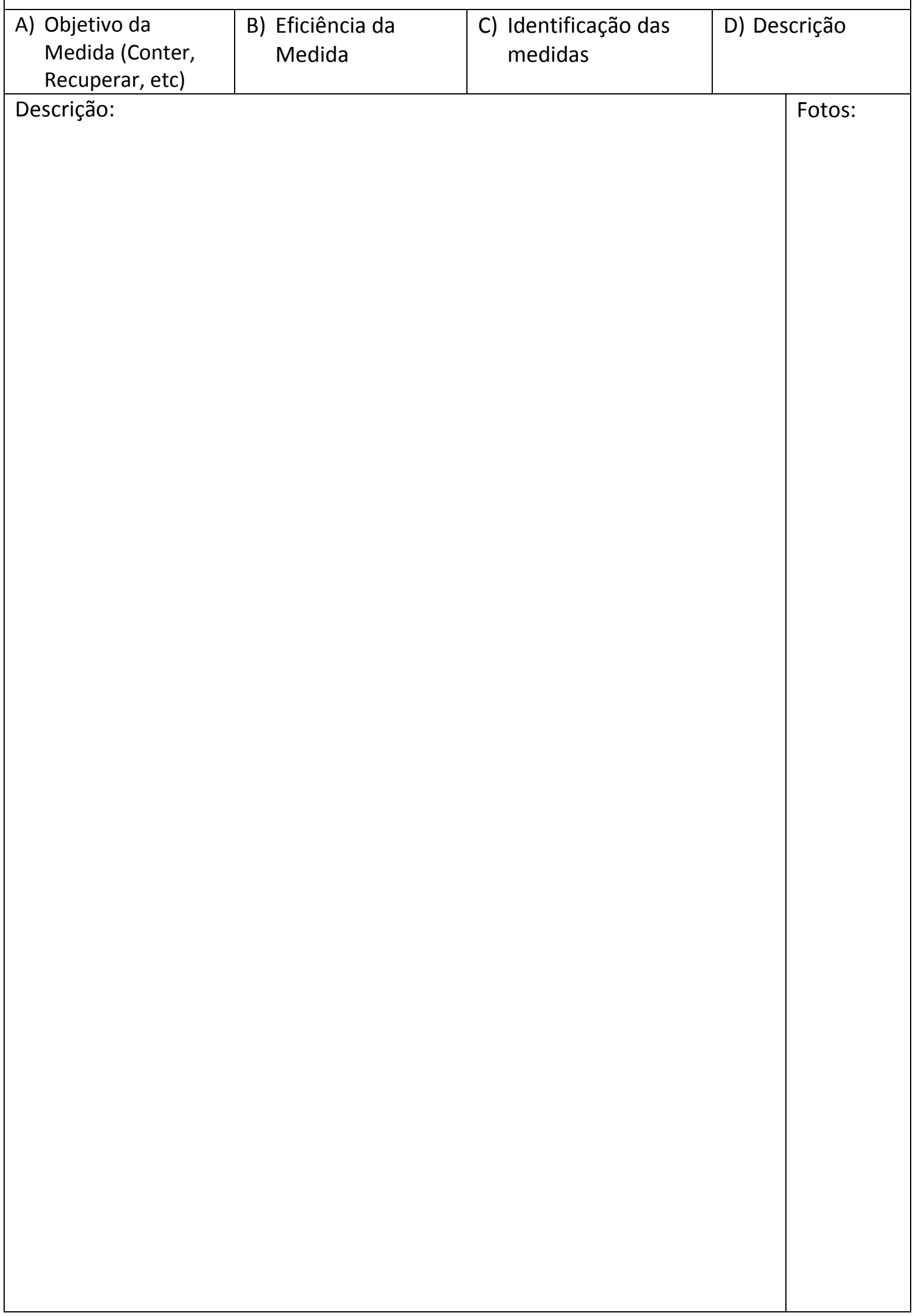




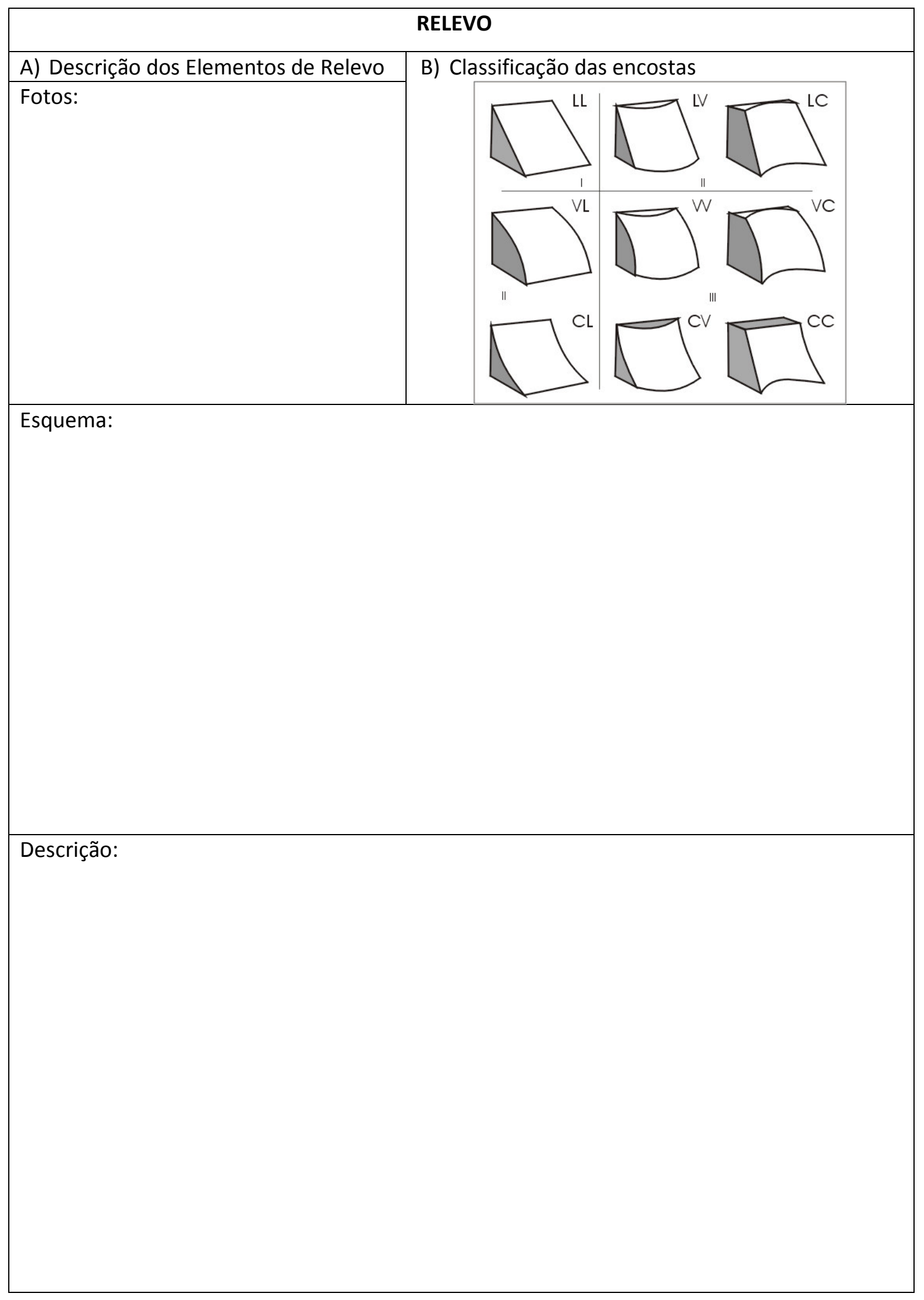

